\title{
An Introduction to the Commercial Law of Afghanistan
}

\section{Statutory}

Supplement

Afghanistan Legal Education Project (ALEP)

at Stanford Law School

www.afghanistanlegaleducation.com

afghanistanlegaleducation@gmail.com

Stanford Law School

Crown Quadrangle

559 Nathan Abbott Way

Stanford, CA 94305-8610

www.law.stanford.edu

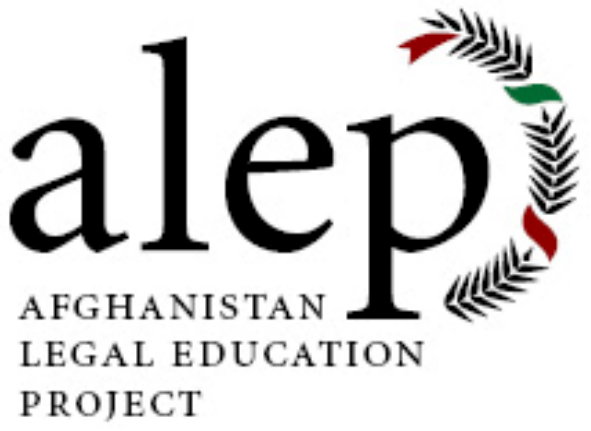




\title{
Afghanistan Legal Education Project (ALEP) 2008-2009 Student Members
}

\author{
Una Au \\ Raaj Narayan \\ Max Rettig \\ Scott Schaeffer \\ Anne Stephens \\ Eli Sugarman
}




\section{TABLE OF CONTENTS}

LAW OF COMMERCE (COMMERCIAL CODE) ................................................. 1

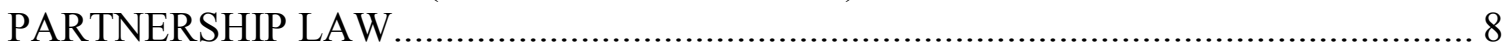

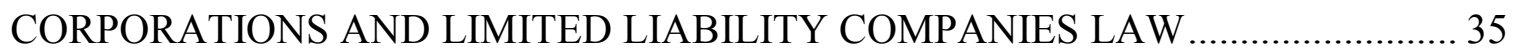

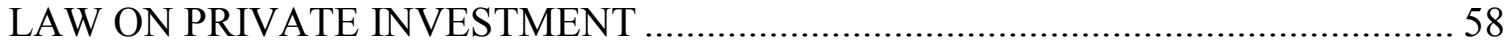

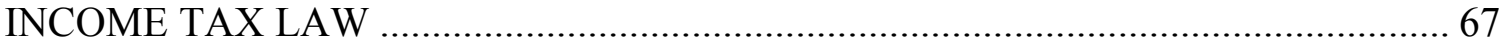

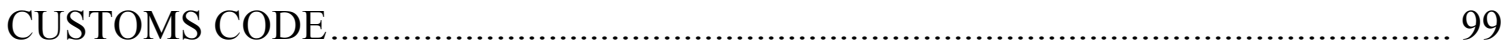

LAW FOR SECURED TRANSACTION ON MOVABLE PROPERTY IN BANKING

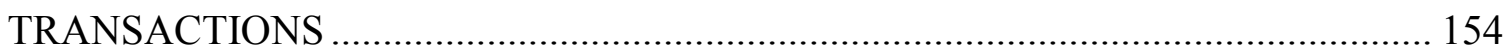

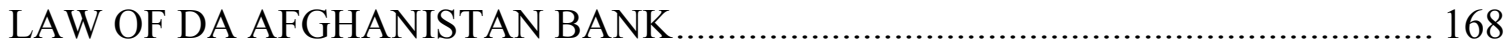

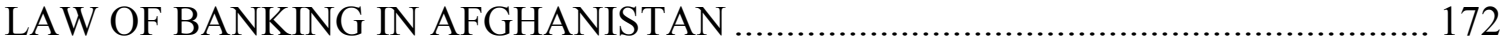




\section{LAW OF COMMERCE (COMMERCIAL CODE) Selected Provisions}

\section{Chapter 1 - Introduction}

Article 1: The provisions of the Commerce Laws are applicable to all commercial transactions.

Article 2: Commercial disputes are to be settled in accordance with legally binding agreements and in their absence disputes are to be determined and settled by reference to the meaning and implication of existing commercial laws. In the absence of a law, local and special customs (those that are commonly recognized, consented to, and used) are applied. Local customs and practice are preferred to general custom. In the absence of any other of the above - mentioned methods any other laws which might apply to the dispute are used.

Remark: The preference of local and special custom and practice to general custom and practice is given because the custom of and practice of locality are the out come of business transactions of the area. If a clear-cut custom relating to a dispute in one particular locality does not exist, the custom of the nearest locality to this dispute is applied.

Article 3: In the absence of any other explicit laws, the contents of Article 2 are applied.

\section{Subchapter C - Commercial Transactions}

Article 14: For merchants / non-merchants who purchase movable and personal property for sale or lease to other persons in original or altered form, the sale or leasing of such properties is considered a commercial transaction.

Article 15: Leasing of movable and personal property by merchants and non-merchants for the purpose of leasing it to others is considered a commercial transaction.

Article 16: Employment of persons for the purpose of contracting them to others by individuals, whether merchants by vocation or otherwise, is considered a commercial transaction.

Article 17: If a landowner, farmer, or a cattle-raiser sells his products or changes them to other forms before selling them, such action should be considered as normal or ordinary activities. Similarly, if a farmer with agricultural and industrial machines or plants exchange his product - or if a professional person or his employee (or his machines) produces his professional product and sells them; or if an author publishes his books and sells them, these activities constitute ordinary activities. But if a person for the purpose of changing his agricultural product opens a permanent establishment possessing the qualities of an industrial business, this is considered a commercial transaction.

Article 18: The following transactions are commercial and business transactions:

a. Agreement to provide any kind of movable property and accept any kind of activities and products.

b. Establishment of a power plant or press; photography; printing; and selling of books.

c. Establishment of theaters, movies, parks and public places, e.g., hotels, business compounds, restaurants and the like, employment offices, and auction places.

d. Transportation of passengers, animals, and goods via land, air, and water

e. Distribution of water, gas, electricity and the establishment of telephone communication.

Article 19: The following transactions are commercial transactions regardless of the parties concerned:

a. Working for commission. 
b. Brokerage.

c. Bill and draft transactions (whether recorded in the name of a person or a bearer).

d. Money exchange transactions.

e. Transactions made by private and public (special and general) banks.

f. Transaction relating to current accounts and agreements thereof.

g. Transactions relating to mortgage documents and receipts existing against goods placed in commercial general storehouses.

h. Establishment of commercial companies and buying and selling of shares.

i. Contraction of any kind of insurance for all risks whether for fees or for reciprocal terms.

Article 20: All transactions of a merchant are assumed to be commercial unless proved ordinary.

Article 21: If an agreement between parties is commercial to only one of the parties, provided there are no statements to the contrary in the law, the obligation arising form this agreement on the part of the contractors are subject to the Commercial Law.

Article 22: Obligations arising for a merchant or non-merchant from other transactions or from transactions or from transactions similar to those mentioned in this chapter, are inherently subject to the regulations of the Commercial Law.

Article 23: All transactions relating to the transactions of this chapter are taken as commercial transactions.

\section{Subchapter D - Business Registration}

Article 24: The business Registration Office, supervised by the courts, deals with the solution of problems and the hearing of cases arising from commercial disputes.

Article 25: Responsibilities for the operation of the Business Registration Office, under the direct supervision of the president of the related court, shall be delegated to a responsible and authorized officer.

Article 26: If there are many commercial courts in one locality, the Business Registration Office, by the decision of the higher authorities, should be placed under the supervision of one of these courts.

Article 27: All matters and transactions subject to registration by commercial or other laws are registered directly or by request made through related agencies or other concerned parties. Any chances brought about related matters must be filed and registered according to rules.

Article 28: The following are to be registered by merchants and commercial firms:
a. Name of the person or firm.
b. Father's name.
c. Place and date of birth.
d. Citizenship of person or firm.
e. Business title.
f. Field of business .
g. Kind of firm as well as its date of establishment and home office.
h. Capital of firm (small business are exceptions).
i. Individual authorized to sign in affairs of the firm.
j. Any other specifications which are compulsory must be registered.

Article 29: Interested parties, as well as their heirs and agents may be authorized to make request for registration. In case more than one person is authorized to make the registration request, if the registration is made through request of one of them, it is considered to have been made through the request of all of them. 
Article 30: Since registration may be initiated either by personal request of interested parties or by their legal agents, they are executed by submission of papers formally prepared and considered and containing registration information.

Article 31: Request for registration must be made during the period prescribed by law for this matter. If no such period is fixed by law, the registration must be completed within one month from date of completion of documents. For persons who must register but who live far from the place of registration, due to the distance. One day is added for each 12 miles.

Article 32: The registration that must be advertised should be in local, official, or private papers until such time as a special paper for the purpose of official advertising is created. In case there is no local paper, the matter should be advertised in the local paper of the closest vicinity. Except in special cases where advertisements are legally permitted to be omitted, the subject of the registration should be published word by word. If the advertisement takes more than one issue of the paper, the last day of advertisement is considered the completion date of advertisement. The number and date of registration must appear or request paper, securities, and advertising newspaper, and must be recorded.

Article 33: Subjects awaiting court decisions or those concerning which the registration officers have some question could, by the request of the interested parties, be temporarily registered. If within six months of the temporary registration the matter is settled, it is permanently registered according to the, law, otherwise it is omitted from the registry.

Article 34: If the registered item, in all or in part, should no longer exist, the registered item could, on written request of the concerned parties, ( which should be accompanied by necessary supporting papers), be omitted in whole or in part as necessary. For items whose registration it was necessary to advertise, their omission is advertised as well.

Article 35: In regard in execution of the registration by the officer of registration, the omission and changes related to thereof, submitted by an interested party, could be objected to by relevant officers of registration. Such objection is given the consideration of the court and a decision will be made. In the case the method followed by registration of officers should also affect a third party, the matter should be taken by the court, heard, and a decision made as a legal case in presence of the third person and the objector.

Article 36: Anyone may study the contents of a registry and the recorded papers related thereto to investigate their corrections, and they may request an authenticated copy of the registration.

Remark: In such cases, a certification fee is charged as follows:
a. For each study (one Afghani)
b. For receiving a copy with no confirmation and certification (5 Afghanis)
c. For receiving a certified copy (20 Afghanis)

Article 37: The individuals required to register who have not done so are subjects to compensate those individuals who have been affected by this negligence. Moreover, by recommendation of registration officer to the related court, such a person could also be fined in cash. Such people made to compensate for loss received by others can appeal to court of appeals or to Supreme Court, provided the compensating money is placed in the court safe or provided they submit a guarantee before the case is accepted for further hearing.

Article 38: Subjects registered in the Registration Office can affect and have legal competence in relation to a third party but the subjects not registered that legally should have been do not affect the third party, even though they have been advertised by special channels. This much should be mentioned - that the obliged persons against other could claim and prove their awareness of the matters that should have been registered. 
Article 39: Individuals who, in bad faith, commit fraudulent acts in registering are subject to a cash fine or imprisonment or both. These people for a period of time, are deprived of the right of membership in Chambers of Commerce and industry, and are not allowed to carry out transactions in stock exchanges.

Demand for reimbursement of losses on the part of others because of this fraudulent act is permitted and the Court should give consideration to it whenever the demanding person requests it.

\section{Chapter Five - Business Title}

Article 40: Every merchant is obliged to sign and execute his business transactions under a definite title known to be his business title.

Article 41: Every merchants whether alone or in partnership with another, and also every commercial company must register and advertise his or its business title in the Registration Office of the district where his or its business office is located or where business transaction are taking place.

Article 42: The business title should be composed of names of the merchants and his family and must be clearly distinguishable from titles already registered. Every merchants can add and bring changes to his business title provided this change does not create any wrong impression about the identification of the merchants himself, or about the existence of his close partner in the mind of a third party.

Article 43: The title of a general partnership (Kollektif Sirkat in Turkish, Sherkat Tazamoni in Dari) must be composed of the names of all partners, or it should, at least, contain the name of one partner and include the word "Tazamoni",or general partnership.

A special partnership (Sherkat Tazamoni-Mekhtalet in Dari, Komad in Turkish) company is organized on the ordinary basis of its capital being divided into shares. As mentioned in Article 42, the titles contains the name of one of the partners who will have an unlimited responsibility plus the term "Tazamoni Mekhtalet", or special partnership.

The field of activity and purpose plus the term "joint stock company" is indicated the title of joint stock company (Sherkat Sahami). The name may appear in the title of such company.

Article 44: In case a merchant should have registered his business title in a locality, another merchant, even if he should happen to have a name to make this the same title, cannot, unless bringing a change in it to distinguish it from the title previously registered, use this title in that locality as a business title or as a title for carrying out a business transaction. Also, if a merchant or company wishes to open a branch in a locality different from the one in which he or it has registered, and if there is another business going on by that name, there has to be a change in the title of the newcomer business in such a way as to make it clearly distinguishable from the one previously registered there.

Article 45: As the transaction of a business title or the separation of the title from the business firm is not permissible, similarly in the case of transfer of one business firm, if the business title is not specifically provided the title of the business cannot be transferred.

Article 46: Upon the sale of a business, the sellers shall be responsible for their acts and obligations pertaining to operations prior to the data of sale. Likewise, profits and gains accruing from operations prior to sale shall be credited to the sellers of the business. Any provision to the contrary shall be specified in the contract of sale, shall be registered at the Business Registration Office, and shall be advertised in an appropriate trade paper to inform persons concerned with those transactions. Obligations of the buyer, deriving from the above provisions, expire at the end of five years if not appropriately assorted by the seller. 
Article 47: If, upon transfer or grant of a business, the grantee (the one to whom the business is transferred) has not agreed in the grant contract to accept responsibility for all obligations prior to the grant, and has not registered it, the grantee is not responsible for the obligation of the grantor.

Article 48: The buyer of a business who has acquired a business according to Article 46 shall include in the title of the business subsequently and appropriate phrase to show his operation as the successor of the seller. Failure to do so makes the seller (or the transferor) who has agreed with the buyer (or transferee) to use the business title responsible for all obligations which the buyer has rendered under the same title. However, this is conditioned to the fact that if the debts are received due to an appeal of the creditors, by the court, the seller would not be responsible any more.

Article 49: In the case of the death of a partner whose name was a part of the title of a company, if the heirs of the deceased continue in the business, the title of the company should not be changed. If the heirs do not participate in the company and give a written approval to the effect that the name of the deceased partner could be used, the title of the company need not be changed.

Article 50: In case the title of a business is changed, the contents Articles 41 are applied.

Article 51: In case a person intentionally uses the business title of another, on his merchandise files, letters, and articles related to his business, or sells or offers the goods marked under the title of another business, he is liable to find or imprisonment or both; provided that there should not be any interference with the contents of Article 54 application of the punishment of this Article is restricted to suits brought by an individual. The accuser can take back his complained but this will also invalidate the suit regarding the common rights.

Article 52: Those deviating from Articles 40, 41, and 42 and the last paragraph of Article 43 and from Article 45 are fined in cash.

Article 53: All courts and officials of Chambers of Commerce, industries, and the registration office, when informed about business title not having been registered, and which is contrary to Article 40, 41, 42 and 43, are supposed to inform the related authorities.

Article 54: Regardless of the manner in which a business title is used contrary to the contents of this subchapter, the concerned parties can ask for the prohibition of its use or, if registered, can ask for its invalidation. Moreover, if others should happen to have suffered loses through the use of such titles, regardless of whether the title was used intentionally or through mistake, those who have suffered are entitled to claim the loses suffered by them. The court can investigate the matter and the loses suffered, through informed sources, and decide as it thinks proper. In addition to the above, if the accusers wishes and agrees to pay the expenses, he can public the findings of the decision of the court.

\section{Subchapter G - Commercial Books}

Article 65: Every merchant must keep three books - a book showing his capital, a ledger, and a journal. Moreover, he must regularly keep a copy of all outgoing letters and telegrams and the original of all incoming letters and telegrams with all papers relating to the payment.

Article 66: A merchant may, if he keep other books for his business but these books are not subject to the regulations mentioned in the following Articles.

Article 67: The merchant does not have to enter everything personally on the books; he may hire a person to do so, but the merchant himself is personally responsible for anything in his books.

Article 68: The books kept according to Article 65 are to be taken personally by the merchant or his agent to the local registration office for marking and sealing. The registration should mark all the pages with ink 
and seal them. Then the office will note the total sheets of each book on its first and last pages. After nothing the date besides the seals of the first and last pages, the registration office should also include there a certified signature.

Article 69: The book containing the asset items of the merchant should contain the following:

a. The cash on the first day, as well as the approximate value of all movable and immovable goods and properties specified for his business, as well as the value of all shares and bonds issued based on current prices, and all the receivable claims whether based on documents or otherwise.

b. All receivables and credits due by virtue of contracts or any other means.

c. After determination of net assets, that is, assets minus liabilities, the merchant at the end of each financial year must prepare a balance sheet indicating assets and liabilities of his business. The balance sheet must be made out at least once a year.

Article 70: At the start of the business, when the real capital of the merchant is determined according to Article 69, and is recorded in the daily journal, all transactions relating to buying and selling, whether commercial or ordinary, as well as his personal expenses, shall be noted by daily in the journal.

Article 71: All correspondence by the merchant should be briefly registered in an indicator filing system in original and copy, as well as all outgoing and incoming letters and telegrams.

Article 72: All decisions reached by the general assembly and the board of directors, with the names of all those present and the date of the meeting, and such other information which might complete the record of the meeting, should be entered into the Decision Book and undersigned, in the name of the company, by all those authorized to do so.

Article 73: Merchants or their successors who might continue in business must keep the required books (from the date of the last entry mentioned in the books), and letters and telegrams from their date for a period of fifteen years.

Article 74: All books and related commercial correspondence pertaining to inheritance, partnership, or bankruptcy, at the time of their surrender can be investigated both by the court and by interested parties.

Article 75: During the hearing of a disputable case, the court can, by its own wish or by the request of one of the parties, order the commercial books and papers to be shown.

Article 76: In case the books and papers to be shown are in the possession of a court different from the one in which the case is heard, and if it is difficult to show them in the court, the court can formally request the other court having possession of the required papers to send a correct and reliable copy of the required parts.

Article 77: The responsibility which arises from not having necessary commercial books or the fact that books have not been legally and properly kept rests personally on the owner of a business and the merchant cannot put the blame on others and acquit himself.

Article 78: In case the necessary commercial books are destroyed by such accident as fire or other hazards during the time in which they were supposed to be kept safely, the merchant or his legal agent in a month's time should bring the matter to the attention of the related court. The court after investigation and after satisfying itself with the accuracy of the matter, will provide the person with certificate to this affect.

Article 79: During a dispute between two merchants over business transactions, the legal commercial books could be used, under the terms mentioned in Articles 80 and 84, as evidence.

Article 80: The contents of the legal business books may be used against the owner or his followers and descendents, regardless of whether legally kept or not, but these contents cannot be used to the advantage and benefit of the possessor unless kept according to the regulations affecting such books. 
Article 81: If the contents of the books of a merchant are according to regulations but should be contradictory to the contents of books of another merchant, the contents of the books of any one of the parties, if proved false with strong evidence and reliable reason, could lose their effect as evidence.

Article 82: If the books of a merchant are legally kept and the books of the opposite party are illegally kept, or if he should not happen to have any books, or if he refuses to submit his books for examination, the contents of the books of the first-mentioned merchant could be used against the second one, but if the second merchant proves the falsehood of all the statements brought against him with strong reasons and evidence, the contents of the books of the first merchant lose their proving effect.

Article 83: If a merchant agrees in court to accept the contents of the books of an opposition party, and if the opposition party refuses to submit his books for examination, the court may make a decision favorable to the first merchant, according to the judgment of the court.

Article 84: In case the court finds the contents of the books of a merchant kept according to the law, and wishes to use these contents in favor of the owner, the court can, for the sake of satisfying itself as to the accuracy of these contents, and fulfilling its moral obligation, undertake an additional investigation, and after satisfying itself can make the necessary decision. This supplementary investigation should in no way more than fifteen days. 


\section{PARTNERSHIP LAW}

In the Name of Almighty Allah, the Beneficent, the Merciful

\section{CHAPTER 1 GENERAL PROVISIONS}

ARTICLE 1. The Basis:

This Law is enacted in the light of the provisions of the Afghanistan Constitution to regulate the affairs related to activities and creation of Partnerships.

ARTICLE 2. Definition of Partnership:

Partnership is an association of two or more persons to carry on business for profit as coowners, as governed by the Partnership Agreement.

ARTICLE 3. Types of Partnerships:

Partnerships are of the following types:

General Partnership(s);

Special Partnership(s);

Work Partnership(s);

Credit Partnership(s).

\section{ARTICLE 4. Partnership Agreement:}

A "Partnership Agreement" is either a written or an oral and implied Agreement among the Partners of the Partnership including any subsequent amendments thereto [that] has no effect on the rights of third parties, unless the third party is aware [of the Partnership Agreement] before transacting business with the Partnership.

ARTICLE 5. Signing of Contracts:

Partnership shall have legal personality and may sign contracts in its own name, and execute transactions and possess movable and immovable properties in the name of the Partnership.

ARTICLE 6. Assets of the Partnership:

The right of establishment, of lease, of name, of title, of patent, of trademark, of models and drawings which are used to perform commercial and industrial services, may be property of a Partnership and title may be held in the Partnership's own name.

\section{ARTICLE 7. Payment of the Capital:}

Capital contributions to Partnership shall be made in the following forms:

Movable tangible property (suc $\mathrm{h}$ as cash, articles, and animals);

Movable intangible property (such as royalties, patents, trademarks industrial marks, and commercial credit and goodwill);

Immovable property including, [but not limited to,] real property;

Profits and privileges from the use of movable and immovable properties;

Products and processes;

Commercial credit and goodwill;

Services performed or to be performed for the Partnership. 
ARTICLE 8. Contribution of Capital and Delay in Contribution:

If a Partner does not pay such Pa rtner's share of the Partnership capital, the Partner is indebted and responsible to the Partnership for making the contribution, and shall pay interest on the contribution from the date determined for such contribution [until the time it is paid]. If a Partner's late payment causes a loss to be suffered by the Partnership, the Partner must pay damages for the loss suffered to the Partnership.

ARTICLE 9. Valuation of property:

The value of property, including third-party indebtedness, accepted as capital [contribution] shall be determined by the Partnership Agreement. If it is not determined [by the Partnership Agreement], the current market value of the articles shall be valid. In case such articles do not have a current market value or its price can not be determined on the current day, the value determined by informed individuals [experts] shall be regarded valid by the parties.

ARTICLE 10. Transfer of ownership:

Unless there are provisions to the contrary in the Partnership Agreement, the property accepted as Partnership capital shall be considered the property owned by the Partnership.

ARTICLE 11. Attention to Partnership Affairs:

Every Partner is obliged to pay such attention to the affairs of the Partnership as if they were his personal affairs.

ARTICLE 12. Negligence in [Performance of] Duty:

Each Partner is responsible to the Partnership for any loss that may be suffered by the Partnership through such Partner's negligence, fault, or deviation of his working authority. Such Partner may not evade the compensation of loss for the reason that it was useful for another case. The Partners may agree to indemnify and hold harmless each other for harms suffered by the Partnership due to negligence of all or specified Partner, to the extent related to their own rights.

ARTICLE 13. Claim of Partners for Wages:

None of the Partners are entitled to claim a wage for the work they perform [for the Partnership], unless receiving a wage is stipulated in the Partnership's Agreement.

ARTICLE 14. Wages as a Percentage of Profit:

Concerning the wage paid out to employees of a Partnership for the services they rendered, if such payment is determined to be partially or totally as a share in the benefits of the Partnership, they shall not be considered as Partners of the Partnership.

ARTICLE 15. Profit and Loss of Each Partner:

Unless [otherwise] provided by the Partnership Agreement, the profits and loss shall be distributed to each Partner proportional to such Partner's capital contributed to the Partnership.

ARTICLE 16. Distribution of Profit and Loss:

If the manner of distribution of either loss or profit is not contained in the Partnership 
Agreement, the other is also distributed in the same manner.

ARTICLE 17. Payment of the Profit Limited by the Agreement:

If an agreement between the Partners and third parties restricts the profit to one or some of the Partners, or if it excludes one or some of the Partners from the loss, such Agreement shall be invalid. In this case the manner of distribution shall be considered as unknown and the profit and loss should be distributed among the Partners in accordance with Articles 13 and 14 of this Law. However, in case of a Partner whose endeavors and work is taken as capital in the firm, and the Partnership Agreement provides that such Partner is not affected by the loss of the firm, this arrangement shall be valid.

\section{ARTICLE 18. Preferential Conditions:}

In the absence of a [written] Partnership Agreement, each Partner participates equally in the possession of Partnership capital and distribution of profits and losses of the

Partnership. If the Partnership Agreement contains a provision governing the possession of Partnership capital, distribution of profits, and losses of the Partnership, such provision shall have preference.

\section{CHAPTER 2 PARTNERSHIPS}

ARTICLE 19. Continuation of Activities:

If a Partnership continues to do business after the expiration of its determined period, it shall be considered as having indefinite existence [thereafter].

\section{ARTICLE 20: Completion of Le gal Existence:}

Legal existence of a Partnership shall be established upon the association of two or more persons as co-owners of a partnership and shall be completed upon registration in the Central Registry. A Partnership shall be liable if it carries out any transaction before registration in the Central Registry. In such case the Partnership may not enforce its rights against third parties unless notified in the Central Registry.

\section{ARTICLE 21. General Partnership:}

A "General Partnership" is one which is established for the purpose of carrying out economic or business transactions between two or among more persons with collective responsibility. If the capital of the General Partnership is not sufficient to pay the debts of the General Partnership each of the Partners is responsible to pay all the debts of the General Partnership and the Partner, or Partners, paying such debts shall be entitled to receive contributions from the other Partners.

\section{ARTICLE 22. Special Partnership:}

A "Special Partnership is a Partnership established under a specified title in accordance with the provisions of this Law for the purpose of carrying out economic and business transactions, in which one or more Partners have unlimited liability (General Partners) and the rest of the Partners have limited liability with a definite capital (Special Partners). The capital of the Partners with limited liability can be divided into shares.

ARTICLE 23. Work Partnership:

A "Work Partnership" is an association of two or more persons who perform work or fulfill 
an obligation for another person. The profits of the work of the Partnership shall be distributed between them as agreed by the Partners.

ARTICLE 24. Credit Partnership:

A "Credit Partnership" is a company in which two or more persons agree to buy goods on credit to sell them and to share the profits and losses of the Credit Partnership. Each of the Partners shall be responsible for his specific part.

ARTICLE 25. Terms of the Partnership Agreement:

Partnerships, whether general or special, must include the following conditions, as a requirement, in the written Partnership Agreement:

(1) Date of concluding Partnership Agreement;

(2) Name, identity, and address of each Partner and if a Partner is another company, the title of that company;

(3) Business location and type of business;

(4) The fact that the company is a Partnership company;

(5) The title of the Partnership;

(6) The names of all the Partners who are jointly or severally authorized to acquire legal possession and sign;

(7) The capital contribution committed by each Partner, the approximate value of non-cash capital, and the method applied to determine such approximate value;

(8) Each Partner's share in loss and profit; [and]

(9) If the General or Special Partnership is for a limited period, the date for expiration of its term;

(2) In addition to the conditions provided in Paragraph (1) of this Article, the Partners may include any other terms and conditions in the Partnership Agreement, which are deemed useful by the Partners.

ARTICLE 26. Duration of Partnership:

A Partnership can either be for an unlimited duration, or for a definite term. Unless the Partnership Agreement specifies a definite term, the Partnership is deemed to have an unlimited duration.

ARTICLE 27. Registration:

"Register" means making recordation in the "Central Registry". For the purposes of this Law, the term "Central Registry" means a Government office under the Ministry of Commerce and Industries where the documents related to companies shall be recorded.

ARTICLE 28. Court:

"Court" means the competent Commercial Court of Afghanistan.

\section{CHAPTER 3 RULES OF PARTNERSHIP}

ARTICLE 29. Scope of Application:

The provisions of this CHAPTER shall apply to all Partnerships covered by this Law, unless otherwise provided for in CHAPTERS 4, 5, and 6 of this Law. In such a case, the provisions [of these chapters] shall prevail.

ARTICLE 30. Damage of Goods: 
The partners are as trustee towards each other and the goods of the partnership are like trust to the partne $r$. If the goods are damaged without fault or encroachment of the partner, the partner shall not be liable, but if the goods are damaged due to fault and encroachment of the partner, the partner shall be deemed responsible.

\section{ARTICLE 31. Failure to Pay Share:}

Where a Partner has agreed to contribute cash to a Partnership and fails to make such a contribution, the Partner shall be bound, without any judicial demand or announcement, to pay the legal interest accrued as well as to compensate the Partnership for the damage inflicted on the Partnership since the time when the payment of the share is not made.

ARTICLE 32. Equivalent Payment:

If a Partner does not make a promised contribution of property, other than cash, the Partner is obligated to contribute money equal to that portion of the value of the stated contribution which has not been made.

ARTICLE 33. Performance of Action in the Agreement:

(1) If a Partner's contribution is of action or services, the Partner shall either perform the services he had committed or shall contribute money equal to the value of the services.

(2) The share of performance shall be considered paid with the practical performance of the action to which a Partner is committed. In such case, such Partner shall be responsible only for the services he performs for the Partnership.

\section{ARTICLE 34. Contribution of Partner in the Form of Debt:}

If a Partner's contribution is in the form of a debt to the Partnership, the liability of the Partner shall be deemed fulfilled when the debt is paid to the Partnership in due time. In case of non-payment, the Partner shall be bound to compensate the Partnership for the loss incurred from the deferred payment of the debt, in addition to the responsibility which may arise from non-payment of debt in due time.

\section{ARTICLE 35. Distribution of Shares:}

Before liquidation, distribution of shares shall be made at the time and manner provided for in the Partnership Agreement.

\section{ARTICLE 36. Distribution of Unspecified Profit:}

Where the share of each Partner in the profit and loss is not specified in the Partnership Agreement, the share of profit of each Partner shall be distributed in proportion to such Partner's share in the capital of [the Partnership].

\section{ARTICLE 37. Determining Profits and Losses in the Agreement:}

The Partnership Agreement may specify the Partners' shares of profits and losses regardless of the contributions of the Partners. Where a provision of the Partnership Agreement fixes the share of profit of each Partner, and does not provide for the Partners' share of losses, such provision shall be valid for determining the share of loss incurred. Likewise, any provision made in the Partnership Agreement for determining the share of loss of each Partner shall also be deemed valid in determining each Partner's share of profit, unless otherwise stated in the Agreement. 
ARTICLE 38. Share of Partner Limited to Work and Performance:

(1) Where the share of a Partner is limited to such Partner's work and performance, unless otherwise provided in the Partnership Agreement, such Partner's share of profit and loss shall be subject to the use which the Partnership makes from such Partner's service. (2) In case the Partner, in addition to rendering of service or performance of action, pays money in cash or something else, such Partner shall be entitled to a share in return to such Partner's action and to another in return for such Partner's contribution other than the service such Partner performed.

ARTICLE 39. Purchase of Goods by Credit:

In a Credit Partnership, the profits and losses shall be distributed in proportion to the property that each of the Partners bought on credit in the account of the Partnership, and guaranteed [the payment thereof], unless the Partnership Agreement provides otherwise.

ARTICLE 40. Administration of the Partnership:

The Partnership Agreement shall require establishment of an administration. Partners may designate persons from the partners or other than Partners to administer the affairs of the Partnership.

ARTICLE 41. Continuation of Activity:

Where on the basis of a provision stipulated in the Partnership Agreement, one of the Partners is assigned with the task of administering the Partnership, such Partner shall continue with administering the Partnership and the performance of those activities which ensures the objectives of the Partnership are realized, provided such [Partner's] activities and the changes such Partner would bring in the Partnership are free from dishonesty. Assigning such person shall be subject to the terms and conditions of the relevant contract and charter, and dismissal of such Partner without any legal reason or amendment of Partnership Agreement shall not be permitted as long as the Partnership survives, unless otherwise provided in the Partnership Agreement.

ARTICLE 42. Approvals of Partners:

Where the Partnership Agreement provides that the decisions should be made by a majority of votes of partners, a partner may perform an urgent work which if not done would cause a great loss to the Partnership, which can not be compensated, and such decisions shall not be rejected, unless the rejection is for performance of an urgent work which, if not done, would cause a great loss to the Partnership, which cannot be compensated.

ARTICLE 43. Majority Consensus in Approva 1s:

Unless otherwise provided in the Partnership Agreement, approvals requiring majority consent shall mean consent of a majority of the Partners, regardless of their shares [contribution].

ARTICLE 44. Partner's Participation in Management of the Partnership:

The right of Partners to participate in management may be limited by the Partnership Agreement, provided that such Agreement may not limit a Partner's right to access information about the management and conduct of activities of the Partnership.

ARTICLE 45. Non-competition and Misuse of Partnership Assets: 
A Partner or Chairman of the Partnership may not compete with the Partnership or use Partnership property for benefit or purposes other than those specified in the Partnership Agreement, unless the Partnership Agreement provides otherwise.

The Partner or Chairman of the Partnership shall be obliged to exert all efforts in the interest of the Partnership in such a way as such Partner would for such Partner's own personal interests.

ARTICLE 46. Receiving Money or Possession of Property by Partners and Additional

Contribution:

(1) Where a Partner acquires or takes possession of some property or a sum [of money] from the Partnership, such Partner shall, without any judicial demand or warning, be obliged to pay the interest from the date such Partner has acquired or taken possession of the property. Such Partner shall also be obliged to pay the compensation for the loss inflicted, if required. (2) Where a Partner spends some of such Partner's property for the benefit of the Partnership, or makes useful expenditures in good faith in the interest of the Partnership, beyond the amount the Partner has agreed to contribute to the capital of the Partnership, such Partner may get the interest of such [Partner's] sums spent, or paid, from the Partnership since the date when the payment is made.

ARTICLE 47. Payment of Debts:

(1) Where the assets of the Partnership are not sufficient to meet its liabilities, each of the Partners shall be obliged to make contr ibution proportionate to their shares of losses from their personal properties, for the fulfillment of the debts, unless otherwise agreed to [by the Partners]. Any Agreement by the Partners on their non-liability for the debts of the Partnership shall not be valid.

(2) Creditors of the Partnership can claim against any of the Partners in the Partnership in accordance with the provisions of this Law.

ARTICLE 48. No Suretyship of Partners against each Other:

(1) The Partners shall not be deemed as sureties against each other with respect to the debts of the Partnership for the payment of which they are made responsible, unless otherwise agreed.

(2) In the event of insolvency of one of the Partners, such Partner's share of the losses incurred shall be divided proportionately among other Partners.

ARTICLE 49. Obtaining Personal Debts:

In cases where the Partnership is ongoing (i.e. not liquidated) and where one of the Partners is indebted the creditors cannot demand their rights from the Share which the indebted Partner holds in the capital of the Partnership. However, such demand can be made out of the profits of the indebted Partner collected in the Partnership. In the event the Partnership is under liquidation, the creditors can demand their rights from the share of the indebted Partner in the capital and profits of the Partnership to the extent such capital and profits are otherwise to be distributed to the Partner. In any case, the creditors have the right to demand from the Partnership to impose precautionary restrictions on the share of indebted Partner.

ARTICLE 50. Dissolution of the Partnership:

A Partnership shall be dissolved in one of the following cases:

1. Expiration of the period set in the Partnership Agreement;

2. Realization of the objective for the achievement of which the Partnership has been established; 
3. Elimination of the whole or most part of the capital of the Partnership as no profit is envisaged to continue with its activity;

4. The death of one of the Partners, or when a Partner is ordered by the Court to be dispossessed, or when a Partner is registered as bankrupt;

5. Withdrawal of one of the Partners from the Partnership when the period of the activity of the Partnership is unlimited, provided that the Partner declares such Partner's intention of withdrawal to other Partners three months in advance. Otherwise, such Partner's withdrawal would be deemed arising from dishonesty or it would be considered inappropriate, unless agreement is made to the contrary;

6. Agreement of the Partners to dissolve the Partnership;

7. Dissolution of the Partnership by Court order; [or]

8. An adjudication of the bankruptcy of the Partnership by the Court, or by agreement of the Partners and creditors of the Partnership to bankrupt the Partnership.

ARTICLE 51. Continuation of the Partnership after Death [of a Partner]:

(1) The Partners may agree that after the death of one of the Partners, the Partnership should not dissolve but shall continue with the heir or heirs of the Partner becoming Partners.

(2) In case of the death, order of Court for dispossession, or bankruptcy of one of the Partners, the Partnership should not dissolve but shall continue among the remaining Partners. In case the Partners do not agree with the heir to continue with the Partnership, such Partner and such Partner's heirs shall not have any right except to the share they hold in the assets of the Partnership according to the daily prevailing price on the day of the event. The share shall be paid to them in cash and such Partner shall not enjoy the rights which may be created later, except what is accrued from the result of the accomplishments of the Partnership prior to such Partner's withdrawal from the Partnership.

\section{ARTICLE 52. Extension of Partnership Activities:}

(1) Where the fixed period of Partnership expires, or the activity for which the Partnership has been established ends, and the Partners nevertheless decide to embark on such activity, which is the objective of the establishment of the Partnership, the Partnership Agreement shall be extended year-by-year with the same terms.

(2) The creditors of one the Partners can object to the extension of the activity of the Partnership provided in paragraph (1) of this Article and can stop the Partnership of the indebted Partner.

ARTICLE 53. Court Decision for the Dissolution of the Partnership:

The Court can make an order [for dissolution of the Partnership] on the basis of a demand made by one of the Partners, by reason of non-fulfillment of the obligations of another respective Partner, or by other rational arguments presented for the dissolution of the Partnership. The Partnership Agreement may not modify this right.

ARTICLE 54. Demand for Expulsion from Partnership :

(1) A Partner may request from the Court the expulsion of any Partner whose activities would result in the dissolution of the Partnership, or cause objection to its extension.

(2) In case the period of the activity of the Partnership is limited, any Partner may request the Court his expulsion from the Partnership by presenting justifiable reasons. In this case the Partnership shall be dissolved unless the remaining Partners agree to the continuation of the Partnership.

ARTICLE 55. Liquidation and Distribution of the Partnership Assets: 
Liquidation and distribution of the assets of the Partnership shall take place according to the terms and conditions provided in the Partnership Agreement. In case the Partnership Agreement does not have such provisions, the provisions of Articles 56, 57, 58, 59, and 60 of this Law shall be applicable.

ARTICLE 56. Continuation of the Activities of a Partnership until Liquidation:

The authority of the Partners shall be limited to taking concerted actions for the purpose of liquidating the Partnership, but the Partnership may continue until the accounts of the Partnership are cleared and the assets of the Partnership have been distributed in accordance with Article 58 of this Law.

ARTICLE 57. Appointment of Persons for Liquidation of Partnership :

(1) The Partnership shall be liquidated by Partners, or the person or persons appointed by the majority of votes of the Partners.

(2) Where the Partners appoint no person or persons by majority of votes, the Court shall appoint one of the Partners on the request of one of the Partners, as liquidator.

(3) In case of dissolution of the Partnership by judicial proceeding, the Court shall appoint the liquidator and determine the scope of such liquidator's authority and the liquidation procedures, on the demand of interested persons.

ARTICLE 58. Partnership Activities and Sale of its Assets by Liquidators:

(1) The liquidator of the Partnership cannot embark on new activity in the Partnership unless it is complementary to the previous activities and consistent with dissolution of the Partnership.

(2) The liquidator may sell, by way of bidding or otherwise, the property of the Partnership, whether it is immovable or movable, unless such liquidator's authority was restricted during [such liquidator's] appointment.

ARTICLE 59. Distribution of Partnership Assets:

(1) The assets of the Partnership shall be distributed among the Partners after the payment of immediate, mediate, and disputed debts, expenses incurred and loans taken through one of the Partners in the interest of the Partnership.

(2) A sum [of money], equivalent to the share held in the capital of the Partnership, shall be appropriated to each Partner, according to the Partnership Agreement. In case the value of the share is not described in the Partnership Agreement, such value shall be calculated from the time of delivery, unless the share of the Partner is limited to performance of action and consultation or allocation of a part of [its] property for the benefit of the Partnership or only for profit.

(3) To the extent the Partnership Agreement does not provide for distributions on liquidation of the Partnership, the property of the Partnership remaining after the payment of debts shall be divided among the Partners proportionate to their respective shares.

(4) Where after payment of the sums provided in paragraph (1) of this Article the residual property of the Partnership is not sufficient for the Partners, the shares of the loss shall be calculated and distributed proportional to the shares of Partners.

ARTICLE 60. Application of the Provisions of the Civil Code relating to Jointly-owned Property:

Where there are no provisions with regard to distribution of the assets of a Partnership in this law, the provisions pertaining to the distribution of jointly-owned properties in the Civil Code shall be observed. 


\section{CHAPTER 4 \\ GENERAL PARTNERSHIPS}

ARTICLE 61. Establishment of Partnership:

Within one month from the date the General Partnership is established, persons establishing a General Partnership must register and advertise a copy of the written Partnership Agreement in the locality where the office of the General Partnership is situated.

ARTICLE 62. Establishment of a New Branch:

If a General Partnership should establish a branch outside the region where it is registered, it shall be obliged to register a copy of the Partnership Agreement in the new registry office as well.

ARTICLE 63. Changes in the Partnership:

After a General Partnership has been registered and advertised, any changes to the General Partnership regarding its title, business location, authorized signing Partners, withdrawal or inclusion of Partners, increase or decrease of Partnership capital, dissolution of the General Partnership before, or continuing beyond the specified period, or amalgamation with another company, must be put in a statement signed by all Partners. This statement must be registered in the relevant office and any other changes may be registered therein.

\section{ARTICLE 64. Prohibition on Using Details:}

Information that is to be registered and advertised according to ARTICLE 61, or registered according to ARTICLES 62 and 63, cannot be used against a third person before registration and subject to ARTICLE 61 cannot be used against third person before advertisement, unless the third person has prior knowledge of the facts that require registration. If before registration and advertisement, a transaction has been concluded in the name of the General Partnership, the General Partnership is responsible to the third party. In case the General Partnership has not been registered and/or advertised as required by Law and the Partners deny existence of the Partnership, third parties can prove the existence of the General Partnership by whatever direct or circumstantial evidence.

ARTICLE 65. Conducting Transactions in the Name of the Partnership:

If the registration and advertisement of a General Partnership has not taken place during or after the period of time prescribed in ARTICLE 61 of this Law, until Registration of dissolution whatever transactions are made in the name of the General Partnership do not damage the interest of third parties, unless the third parties have knowledge of the dissolution.

ARTICLE 66. Relationships between the Partners:

Relationships between the Partners of a General Partnership are governed by the Partnership Agreement, and the terms and conditions of the Partnership Agreement may be included in writing either in the contract document or the supplementary documents thereof. Where no terms and condition are provided in the Partnership Agreement, the provisions of this Law shall apply.

ARTICLE 67. Delegation of Administrative Affairs of the Partnership :

Unless otherwise provided in the Partnership Agreement, the day to day administration of the General Partnership, by majority of votes, may be delegated to one, some, or all of the 
Partners, or delegated to a person outside the General Partnership. Any person delegated with such authority shall be known as "Manager."

ARTICLE 68. Dismissal of the Manager:

If the administrative authority of the Manage $r$ is determined in the Partnership Agreement of the General Partnership, the Partners may limit the Manager's, or Managers' authority, or may dismiss the Manager or Managers only in accordance with the terms of the Agreement, or by unanimous majority [sec] vote of all Partners. If the Manager neglects such

Manager's duties, or is unable to administer the affairs of the General Partnership, the Manager may be dismissed by majority of votes upon the request of one or more Partners for cause shown. In case the Partners reject the complaint of Partners in spite of good cause shown, they may refer the matter to the Court.

ARTICLE 69. Decision on the Daily Management, and Major and Important Issues:

Unless otherwise provided by the Partnership Agreement, ordinary matters and transactions affecting the purpose and objective of the General Partnership shall relate to the day-to-day administration of the General Partnership. The Manager, or Managers, shall be authorized to take action and determine matters concerning the day-to-day administration of the General Partnership using the same standard of care as making decisions about their own business affairs. Important matters outside the day-to-day ordinary matters, including but not limited to matters such as contributions, price, transfer of substantially all the General Partnerships' immovable properties and other matters which are not included in ordinary activities of the Partnership, must be decided by majority votes of the Partners, unless otherwise provided by the Partnership Agreement.

\section{ARTICLE 70. Payment of Loans taken by a Partner:}

If a Partner should take a loan from the General Partnership, or collects a sum of money in the name of the General Partnership (when the Partnership Agreement does not provide otherwise), and does not pay this sum in due time to the General Partnership, in addition to paying the original sum such Partner shall be obliged to pay interest for the late period as well.

ARTICLE 71. Transfer of Shares:

No Partner is authorized to tr ansfer such Partner's shares to a person outside the General Partnership, whether in part or in full, without the unanimous vote of the other Partners, and any loss incurred by Partners or third parties as a result of such transfer shall be the sole responsibility of the transferring person, unless otherwise provided in the Partnership Agreement.

ARTICLE 72. Non-Acceptance of Other Person as Partner:

A person authorized to administer the General Partnership can not accept an outsider as a Partner in the General Partnership or substitute another person for himself in the administration of the General Partnership, without the unanimous approval of other Partners.

ARTICLE 73. Profit from Interest:

The Partnership Agreement may provide for [payment of] interest for the contributed capital.

ARTICLE 74. Access of Partners or Managers to Information: 
Partners and Manager are entitled to obtain information on the activities of the General Partnership as well as its financial status and may use the information for the governance of the General Partnership. The General Partnership Administration may refuse to give information to any Partner, or manager, if there is suspicion that Partner is going to use the information to damage the General Partnership. The Partnersh ip Agreement shall include access to information and refusal to provide them, however, the Partnership Agreement may not unreasonably eliminate or restrict such rights.

ARTICLE 75. Decisions on Daily Affairs of the Partnership:

Amending the Partnership Agreement shall be made by unanimous vote of the Partners and decisions concerning the ordinary course of conducting the day-to-day business of the General Partnership shall be made by the majority vote of the Partners, unless otherwise provided in the Partnership Agreement.

ARTICLE 76. Preparation of Loss and Profit Statement of Partnership:

The Partners, or a manager (if the duty is delegated to a manager), at the end of each fiscal year must prepare the profit and loss statement of the General Partnership based on a balance sheet and determine the share of each Partner according to it. Unless otherwise provided in the Partnership Agreement, distribution of all or part of the shares before the liquidation of the General Partnership shall be decided by unanimous vote of the Partners.

ARTICLE 77. Partner Not Required to Pay Compensation for Loss:

Unless otherwise provided in the Partnership Agreement, a Partner cannot be made to complete such Partner's share of the loss of capital until dissolution of the Partnership, but the amount of loss of capital of the Partners may be paid from the profits made in subsequent years.

ARTICLE 78. Partner's Involvement in Similar Business Transaction and Becoming a

Responsible Partner in Another Company:

(1) Unless otherwise provided in the Partnership Agreement or this Law, a Partner may not execute a business transaction separate from the General Partnership's transactions in such Partner's own, or someone else's, account without the unanimous vote of the other Partners. If the Partners of a newly established General Partnership know that one of the Partners, at the time of joining the General Partnership, has been a responsible Partner of another company, and if the Partners do not object explicitly concerning such Partner's separation from the other company, such Partner's Partnership in the [newly established] General Partnership is considered to have been accepted.

(2) If Partners after receiving information about one Partner's partnership in another company or execution of a transaction by him do not object within six months, their right to complain shall be cancelled. However, they shall have a right to request the Court for dissolution of the General Partnership according to the provisions of Chapter Four of this law.

ARTICLE 79. Existence of the Partnership:

A General Partnership acquires legal personality as of the date of registration and advertisement, and as amended by any subsequent amended registration(s).

ARTICLE 80. Relations of Partners with Third Parties:

The Partners' relationship with third parties shall be subject to the provisions of this Law, except where provisions have been made to the contrary in the Partnership Agreement. 
ARTICLE 81. Transactions by Agents:

A Partner, manager or person, appointed to represent a General Partnership within the authority delegated to him shall be authorized to sign all legal transactions in the name of the General Partnership and bind the General Partnership. Agents of General Partnerships may also conduct business in accordance with the law. All such agents must act in good faith and honesty. Partners may also perform transactions on behalf of the General Partnership that are agreed upon in the contract and bind the General Partnership.

ARTICLE 82. Responsibility of the Partners:

The General Partners shall be jointly and severally responsible for the debts and commitments of the General Partnership.

ARTICLE 83. Lawsuits:

Any claims about the debts and commitments of the Partnership shall be first brought against the General Partnership. In case it is not possible to file a claim against the General Partnership or if the General Partnership has been dissolved, the claim may be made against the Partners. In this case, the Court upon the request of creditors and based on the cause shown, may order that the General Partnership properties and transactions be managed by the Court until the time needed to settle the accounts.

ARTICLE 84. Implementing Judicial Action:

The decision of the Court with respect to the operations of a General Partnership shall be binding on the Partnership.

ARTICLE 85. Payment of Creditors' Rights [Debts]:

In case of liquidation of a General Partnership, the creditors of the General Partnership shall have priority over the personal creditors of the Partners as to the property of the General Partnership.

ARTICLE 86. Court Order to the Creditors' Claims:

The bankruptcy of the General Partnership shall not be considered as the bankruptcy of Partners. In case the assets of the bankrupt General Pa rtnership is not sufficient to fulfill the demands of the creditors, the creditors can claim their remaining debts from the Partners. However, if the property of Partners is also insufficient to satisfy the claims, the Partners may be announced bankrupt by the Court.

ARTICLE 87. Partners Cannot Utilize Assets [of the Partnership ]:

Partners of a bankrupt General Partnership may not make use of General Partnership assets. However, they may claim [their] other claims from the General Partnership as creditors of the General Partnership.

\section{ARTICLE 88. Non Payment of Claims Related to Debts:}

A person indebted to the General Partnership cannot escape the debt if a Partner of the General Partnership is indebted to such person. Neither can a Partner escape the debt such Partner owes to the General Partnership if a person indebted to such Partner happens to owe the General Partnership. But if a creditor of the General Partnership, should not be able to receive such creditor's money from the General Partnership, if such creditor seeks 
payment from the individual Partners and if the Partner from whom the payment is sought happens to have a personal claim on the creditor of the General Partnership, in that case such Partner can use such creditor's claim to pay the debt of the General Partnership.

ARTICLE 89. Duration of Activities of the Partnership:

Unless otherwise specified by the Partnership Agreement, the duration of the General Partnership shall end upon the death of any individual Partner, or the dissolution of any Partner that is a legal person. In spite of this if a General Partnership's duration is not definite and the nature of its business activities is such as to limit the existence of the General Partnership the duration of the General Partnership shall end on the date of completion of the activities.

ARTICLE 90. Dissolution of Partnership:

A General Partnership is dissolved in accordance with the provisions of ARTICLE 53 of this Law.

ARTICLE 91. Conclusion of Valid Partnership Agreement:

If the Partnership Agreement of a General Partnership excludes certain reasons as the causes of dissolution it shall be valid, but if it absolutely excludes all the reasons as the cause of dissolution such provision shall be invalid.

ARTICLE 92. Informing Creditors of Dissolution of the Partnership:

After the dissolution of the General Partnership, the General Partnership must register the dissolution as a change to its existence and must take reasonable actions to notify its creditors and others having transactions with the Partnership of its dissolution. The General Partnership shall then commence liquidation in accordance with the provisions of this Law. All contracts existing at the time of dissolution, or entered before the Registration of the dissolution and notification of third parties, shall remain valid and binding on the General Partnership and its Partners pursuant to this Law.

ARTICLE 93. Informing the Partners of Dissolution of the Partnership:

If a General Partnership is established for an unlimited (indefinite) period, any of the Partner/Partners can, at least six months before the end of the General Partnership's fiscal year, notify in writing other Partners of his/their intention to dissolve the General Partnership.

ARTICLE 94. Court Order for Dissolution of the Partnership:

General Partnerships established for limited or unlimited duration may be dissolved by decision of the Court through the request of a Partner in the following cases:

Non-realization of the objectives of the General Partnership for any reason;

Dishonesty of a Partner whether in administrative or accounting affairs;

Failure on the part of a Partner to perform the principal duties delegated to such Partner; Misusing the title or the properties of the General Partnership by a Partner for personal benefits;

Disqualification and incompetence of a Partner because of a continued illness, or other reasons which will disable such Partner from taking part in the business affairs of the General Partnership; [or]

Failure of a Partner to contribute such Partner's agreed upon capital if an earlier demand for payment has been made to the Partner by one of the Partners. 
ARTICLE 95. Duration of Partnership:

If the duration of a General Partnership is limited, or if duration depends on the life of one of the Partners, after the death of the Partner or termination of such duration, the General Partnership is considered as existing for a time to complete outstanding business transactions consistent with the provisions of this law on dissolution.

ARTICLE 96. Dissolution of the Partnership because of Death, Bankruptcy or Incompetency of one of the Partners:

If the General Partnership is considered dissolved because of the death, bankruptcy, or incompetence of one of the Partners, the heir of the deceased, the legal financial executor of the bankruptcy or his [legal] counsel or the custodian of the incompetent must, without delay, inform the Partners of the matter. If any unreasonable delay in notification damages the business of the General Partnership, the General Partnership may recover damages from the estate of the Partner causing dissolution unless the General Partnership otherwise knows of the event of dissolution.

ARTICLE 97. Continuation of the Partnership after Death or Voluntary Withdrawal of a Partner

When any Partner voluntarily withdraws from the General Partnership or dies, the General Partnership's business may continue without any settlement of accounts as between the voluntarily withdrawn or the heir of the deceased Partner; unless otherwise agreed in the Partnership Agreement. If the withdrawn or heir of the deceased Partner, or such Partner's legal representative have interest in the General Partnership at the date of dissolution, they shall receive, as ordinary creditors, an amount equal to the value of such withdrawn or deceased Partner's interest in the dissolved General Partnership with interest, or at their option in lieu of interest they can receive the profits attributable to the use of such withdrawn or deceased Partner's heir's right in the property of the dissolved General Partnership; provided that the creditors of the General Partnership, as against the creditors or the representative of the withdrawn or deceased Partner's heir, shall have priority on any claim arising under this ARTICLE.

ARTICLE 98. Incompetency of Partner:

If any Partner becomes incompetent, the provisions of ARTICLE 97 of this Law shall be applicable.

ARTICLE 99. Bankruptcy of Partners:

Unless otherwise stated in the Partnership Agreement, in case of the bankruptcy of one of the Partners, the bankrupt Partner is expelled from the General Partnership.

\section{ARTICLE 100. Expulsion of a Partner by Court Decision:}

If the request to dissolve a General Partnership is made by a Partner, the Court may, on request of the other Partners, make a decision to continue the General Partnership and expel the requesting Partner.

ARTICLE 101. Request of Dissolution of the Partnership or Refusal:

If a Partner requests the dissolution of a General Partnership whose business duration is unlimited one or more of [the other] Partners can reject the request for dissolution and continue with the General Partnership. In such a case, the matter concerning expulsion of the Partner shall be referred to the Court in accordance with the Provisions of this law. 
ARTICLE 102. Request of Dissolution of the Partnership by one of the Partners:

If a Partner makes a request based on ARTICLE 94 to dissolve a General Partnership whose term of business is limited, the other Partner/Partners may pay out such requesting Partner's shares and continue the business of the General Partnership.

ARTICLE 103. Transferring the Debts and Assets:

If a General Partnership is composed of two Partners and one withdraws from the General Partnership, the remaining Partner may obtain a Court order transferring title to all the assets of the General Partnership's business without dissolution, or liquidation. In this case the provisions of ARTICLES 104 and 105 of this Law shall be applicable on the withdrawn Partner.

ARTICLE 104. Continuation of Administration and Transactions after Dissolution:

If there should be only two Partners in a General Partnership and if a person to whom a Partner is personally indebted should use such person's right to dissolve the General Partnership as set forth in ARTICLE 108, or if one of the Partners should go bankrupt, the other Partner may, in compliance with ARTICLE 102 of this Law, perform administrative affairs and execute the transactions of the General Partnership in such Partner's own account.

ARTICLE 105. Payment of the Profit of the Partner who Withdraws from the Partnership:

Unless otherwise provided in the [Partnership] Agreement, the value of the General Partnership profit of a Partner who is expelled or who wishes to withdraw from a General Partnership is determined from the value of the assets of the General Partnership as of the date the expulsion demand has been made, and the sum shall be paid in cash.

The profit of a Partner who is expelled or withdrawn according to paragraph (1) of this Article shall be paid at the time provided by the Partnership Agreement, however, if it is not determined in the Partnership Agreement the payment shall be made when the first balance sheet is prepared after the Partner is expelled or withdrawal.

ARTICLE 106. Expelled Partner and Non-involvement in the Decisions of the Partnership:

A Partner who is expelled, or who has asked to withdraw, is to participate in the privileges and responsibilities of the transactions taking place before the expulsion is effective, but such Partner cannot prevent the execution of transactions already acted upon or decided by the other Partners. If the winding up of the General Partnership's business is not immediately possible, such expelled, or withdrawn Partner can ask at the end of the General Partnership's fiscal year for the accounts of transactions which have taken place during such fiscal year. Such expelled or withdrawn Partner also is entitled to request information on current transactions in progress at the end of the fiscal year.

ARTICLE 107. Payment of Personal Debt:

The expulsion or withdrawal of a Partner as it relates to third parties is in effect as of the date of registration and advertisement [of this matter], and prior to the date of such registration and advertisement, such partner shall continue to be responsible to third parties.

ARTICLE 108. Non-satisfaction of Debt:

If a person to whom a Partner is personally indebted should not be able to satisfy such person's claim from the personal properties of the debtor, such person may, at the time of 
the winding up of the General Partnership's business, control, through the order of the Court, the Partner's interest in the General Partnership, and may request [the Court] dissolve the General Partnership at the end of the fiscal year for any of the strong reasons provided in ARTICLE 100 of this law. The General Partnership, or the rest of the Partners, can, before the order to dissolve the General Partnership should become effective, pay the debt, or expel the debtor Partner, in accordance with ARTICLE 105 of this law. In such a case, the order of the Court shall be invalidated.

\section{ARTICLE 109. Merger of Partnerships:}

Two or more General Partnerships may merge or enter into any other type of amalgamation with each other to establish a new General Partnership. In this case the resulting new General Partnership shall be treated as a continuation of the prior General Partnership Companies and shall not be deemed to have been dissolved.

\section{ARTICLE 110. Agreement of Partners for Merger:}

For a merger of General Partnerships with agreement of all partners, separate decisions are to be made by each General Partnership and should be registered and advertised; unless otherwise provided by the Partnership Agreement. The merger shall be effective upon the later of Registration or advertisement.

\section{ARTICLE 111. Preparation of Balances of Merged Partnerships:}

Each of the merged Partnerships must arrange and advertise its balance in unified forms. They must also approve decisions as to payment of debts and these decisions must accompany the balances. Each Partner may receive the balances and an explanation of them before the merger.

ARTICLE 112. Informing the Creditors about the Merger of the Partnership:

The decision to merge General Partnerships becomes effective three months after the date it has been registered and advertised. Each of the merged partnerships shall be obliged to give notice to known creditors of the merger. If the merged General Partnerships pay their debts, or deposit the equivalent amount in a recognized bank, or if the persons to whom they are indebted agree with the merger, it is not necessary to wait three months.

The receipt received from the bank for the amount equivalent to debts is to be registe red and advertised as well. Each of the persons to whom the merged General Partnerships are indebted can, within three months, submit a protest to the relevant Court on the matter of the merger. Until such time as the protester rescinds his protest, or the Court has made the final decision relating to the creditor who has protested, the merger cannot take place.

\section{ARTICLE 113. Period of Time to Object to Merger:}

If during the period mentioned in ARTICLE 112 of this law there should not be any protest, the merger becomes final. The newly created General Partnership is the successor of previous General Partnerships and all the rights and responsibilities are transferred thereto, In this case the new partnership shall be registered and advertised.

\section{ARTICLE 114. Liquidation of Deals:}

If there are no provisions relating to the winding up of the business of the General Partnership in the General Partnership's Partnership Agreement, the winding up of the business of the General Partnership shall be executed in accordance with the provisions of this Law. 
ARTICLE 115. Liquidation of Partnership:

The winding up of a General Partnership's business shall be the responsibility of the liquidating officers.

ARTICLE 116. Partnership's Liquidation Officers:

The liquidating officers shall be:

1. The persons determined as liquidating officers in the Partnership Agreement of the

General Partnership;

2. If the liquidating officers are not determined in the Partnership Agreement, the persons elected as liquidating officers by the Partners either prior to, or after, the Partners' decision to dissolve the General Partnership; [or]

3. In the event that no liquidating officers are determined, each partner or his legal executor is deemed to be the liquidating officer for a General Partnership's business. Where a Partner petitions the relevant Court, the liquidating officers shall be assigned by the relevant Court.

ARTICLE 117. Appointment of Liquidation Officers:

The liquidating officers, whether chosen by the Partners or assigned by the Court, may be among the Partners or persons other than partners.

ARTICLE 118. Decision of Liquidation:

If more than one liquidating officer shall be responsible for winding up the business of the General Partnership, such liquidating officers may work collectively and cooperatively in the winding up of the General Partnership's business. If one liquidating officer is to act independently on any given matter, he is obliged to register such matter with the Central Registry and inform third parties dealing with the General Partnership in the winding up of its business.

ARTICLE 119. Appointment of a Member of Partnership for Liquidation:

If a General Partnership transacts business while the General Partnership is winding up its business, the liquidating officers may elect only one person from among themselves to transact such business with third parties and such transaction is binding against the General Partnership if done for the purposes of winding up the General Partnership's business.

ARTICLE 120. Business Transactions of Partnership during Liquidation:

When a General Partnership's business is being wound up, on all contracts, or other documents, prepared in the name of the General Partnership the Statement "Winding up of the General Partnership" shall be recorded, and shall be signed by the General Partnership's liquidating officer, or officers. In the event that such Statement is not recorded on a contract, or other document, prepared in the name of the General Partnership while its business is being wound up the General Partnership the liquidating officer, or officers, shall be responsible to any third party with respect to such contract or other document, unless the third person has knowledge of the General Partnership's dissolution or winding up of its business.

ARTICLE 121. Preferential Rights:

The priority given to persons to whom the General Partnership is indebted over persons to whom Partners are personally indebted is protected even after the dissolution of the General Partnership.

ARTICLE 122. Insufficiency of Assets for Satisfaction of Debts during Liquidation:

If the assets of the General Partnership at the time of dissolution are insufficient to satisfy the General Partnership's creditors, the Court may issue a decision that ca uses the 
bankruptcy of the Partnership in accordance with the provisions of the Law.

ARTICLE 123. Dismissal of the Liquidating Officer Pursuant to Agreement:

If the liquidating officers of the General Partnership are elected according to the General Partnership's Partnership Agreement from among or outside of the Partners of the General Partnership before or after dissolution, such liquidating officers may be dismissed by the unanimous vote of the Partners. In the event that a unanimous decision [of the Partners to dismiss such liquidating officers] cannot be reached, the Court may order such removal, upon the request of any one of the Partners.

ARTICLE 124. Dismissal of Liquidating Officer by the Court:

A liquidating officer appointed by the Court may only be dismissed by the Court.

ARTICLE 125. Request of Cooperation on Liquidation:

During the winding up of the General Partnership, the liquidating officers may:

1. Request that the managers of the General Partnership (if any) assist in the winding up of the General Partnership;

2. Prepare an accounting of the assets of the General Partnership and the General

Partnership's current balance sheet if the managers do not assist;

3. If necessary, obtain an appraisal of the General Partnership's assets to determine their value. After the managers of the Partnership have signed the books and the prepared balance sheet, take control over, and responsibility for, the General Partnership's assets and accounts in the presence of such managers.

ARTICLE 126. Maintaining the Assets of the Partnership:

The liquidating officers shall be responsible for the safety of all assets and accounts of the General Partnership during the winding up of its business.

ARTICLE 127. Responsibilities of Liquidating Officer:

The liquidating officers are responsible for executing the following:

1. To complete all of the General Partnership transactions that commenced prior to its dissolution.

2. To pay the debts, and other claims, of the General Partnership in cash. If the persons to whom such debts are paid agree, such payment may be in kind.

3. To collect the General Partnership's third party claims and convert assets of the General Partnership into cash.

4. To take necessary actions to execute transactions necessary for the collection of the General Partnership's accounts, and for the distribution of General Partnership assets among the Partners.

ARTICLE 128. The Liquidating Officer as a Representative of the Legal Personality of the General Partnership:

The liquidating officers shall represent of the General Partnership's legal personality, while it is being wound up, before the Courts, or before other legal persons.

ARTICLE 129. Non-execution of Transactions not Related to the Liquidation of the Partnership:

The liquidating officers cannot execute any transactions not related to the winding up of the business of the General Partnership. In the event that they do so, such liquidating officers 
shall assume any responsibility that might arise from such transactions.

ARTICLE 130. Resolution of Partnership's Transactions:

The liquidating officers are authorized to enter into negotiations, or (if necessary) to appoint an arbitrator, to resolve any transactions of the General Partnership.

ARTICLE 131. Sale of Properties of the Partnership:

The liquidating officers are permitted to sell the movable property of the General Partnership, whether at auction or by another way that provides maximum benefit for the Partnership, but the immovable property of the General Partnership, unless the Partners agree otherwise, may only be sold at auction. The presence of a minor or incompetent Partner shall not prevent the sale of the movable, or immovable, property of the General Partnership.

ARTICLE 132. Transacting Business not Related to Liquidation of the Partnership:

The liquidating officers who are appointed by the Court, upon unanimous agreement of the Partners, may, if necessary, execute transactions that are unrelated to the winding up of the business of the General Partnership.

ARTICLE 133. Payment of Installment Debts:

The liquidating officers shall pay any installment debts of the General Partnership with discount as soon as possible where creditors agree.

ARTICLE 134. Payment of Debts:

If the assets of a General Partnership do not satisfy the liabilities of the General Partnership, the Partners shall be responsible for full payment of the liabilities of the General Partnership.

ARTICLE 135. Prohibited Sale of Partnership Properties:

Unless the Partners unanimously agree, the liquidating officers may not sell all of the General Partnership property in one lot.

ARTICLE 136. Increasing and Limiting the Powers:

The legal authority of the liquidating officers may be expanded, or limited, by the unanimous vote of the Partners, or by decision of the Court, if such expansion or limitation is registered with the Central Registry and advertised. If the matter of limitation or expansion of authority has not been registered and advertised such limitation or expansion does not affect third parties dealing in good faith with the General Partnership unless such third parties have knowledge of the facts regarding legal authority of the liquidating officers.

ARTICLE 137. Liquidation of the Partnership Limited to Decision of Partners or Court:

During the winding up of the Partnership's business liquidating officers are bound by any decision made by the Partners or Court relating to the winding up of the Partnership's business. In case of bankruptcy, death, or incompetence of one of the Partners, ARTICLE 138 of this law shall be applicable.

ARTICLE 138. Appointments and Dismissals of Representative: 
In case of bankruptcy, death, or incompetence of a Partner during the winding up of the General Partnership's business, the lawyer, or executor, of such Partner shall have the right to participate in Partnership decisions to appoint, dismiss, or give directions to any liquidating officers. The heirs [of such Partner] may also appoint a lawyer to represent such heirs. If the heirs fail to agree on appointment of a lawyer, or such Partner has no heirs, the Court may appoint a person as lawyer to represent such Partner's profits.

ARTICLE 139. Maintaining Some of the Properties of the Partnership for Payment of Debts:

The liquidating officers may, after retaining the necessary reserves to satisfy debts of the General Partnership, distribute the remaining assets among the Partners.

ARTICLE 140. Responsibilities of the Liquidating Officer:

The liquidating officers shall have the responsibilities as set forth below during winding up the business of a General Partnership;

1. Accurately prepare the final books and records of the General Partnership to secure proper winding up of the business of the partnership;

2. Report to the Partners orally, or in writing, regarding the status of the winding up of the business of the General Partnership upon request of the Partners;

3. Make available all books and records of the Partnership relating to the General

Partnership's liquidation whenever the Partners so request. The liquidating officers may not prevent Partners from copying the General Partnership's books and records.

4. The liquidating officers, during the winding up of the business of the General

Partnership, must deposit any money above the Partnership's operating requirements in a recognized bank.

ARTICLE 141. Recording and Advertising the Decisions of the Partners:

All statements in the General Partnership's Partnership Agreement relating to liquidating officers, together with directives decided upon by the Partners and the Court concerning the appointment, change, and dismissal of liquidating officers, is to be registered with the Central Registry and advertised.

ARTICLE 142. Responsibilities of Liquidating Officer after Termination of Liquidation:

At such time that the winding up of the business of the General Partnership is complete the liquidation officers, according to the Partnership Agreement or to decisions made by the Partners or a Court, must prepare an accounting of the winding up and a balance sheet containing the shares of the Partners in the capital, profit, loss, and other items. The accounting and balance sheet must be submitted to the Partners. If the Partners raise no objection within one month, the accounting and balance sheet are considere $d$ final. After such one-month period, if Partners fail or refuse to accept such Partners' distributions of General Partnership assets, the liquidating officers may deposit such distributions under such Partners' names in a recognized bank.

ARTICLE 143. Distribution of Net Assets among the Partners:

The net assets of the General Partnership, in accordance with the Partnership Agreement or the decision of the Partners, should be distributed by the liquidating officers to the Partners, unless otherwise stated by the Partnership Agreement or as directed by the Partners, such distribution shall be made in cash.

ARTICLE 144. Liabilities of Liquidating Officers:

Liquidating officers are liable to the Partners and third parties for actions taken on their 
behalf by agents, or other representatives, who the liquidating officers appointed to perform their duties to the General Partnership.

ARTICLE 145. Wages of Liquidating Officers:

Liquidating officers appointed from among the Partners may not be compensated, unless so stated in the Partnership Agreement or upon the decision of other Partners. Liquidating officers who are not Partners, regardless of whether compensation has been stated in the Partnership Agreement or otherwise, are entitled to compensation for performing their duties as liquidating officers.

ARTICLE 146. Depositing of Papers in a Safe Location:

At such time that the winding up of the General Partnership's business is complete, the General Partnership's books and records are to be deposited in a safe place designated by the Partners for a period of 15 years from the completion of the winding up of the business of the General Partnership. If the Partners do not agree regarding the place for such books and records to be kept, such place shall be assigned by the Court.

\section{CHAPTER 5: SPECIAL PARTNERSHIPS}

ARTICLE 147. Application of Provisions of Chapter Four:

Unless otherwise stated in this law, rules of this law governing General Partnerships apply to Special Partnerships as well. Where it cannot be decided if a company is a General Partnership or a Special Partnership, it is considered to be a General Partnership.

ARTICLE 148. Registering the Name of Partners and the Capital Paid by Them:

In the Special Partnership Agreement, in addition to the requirements of ARTICLE 152 of this law, the names of the Special Partners, as well as the capital of each that has been paid or promised, should be entered and should be, registered with The Central Registry ,and advertised.

ARTICLE 149. Exception of Some Goods as Capital:

A Partner to a Special Partnership cannot submit such Partner's work, action, reputation, or profession (other than such Partner's scientific and technical invention or other intellectual [property] rights belonging to the Partner), as capital.

ARTICLE 150. Legal Relations of the General Partners:

The legal relations of General Partners to each other, to Special Partners, and to third parties are subject to provisions of CHAPTER 4 of this Law.

ARTICLE 151. Items Included in the Articles of Partnership:

A Special Partnership's Articles of Partnership, established on the basis of its Partnership Agreement shall include:

(1) The name of the Special Partnership;

(2) The address and name of its registered agent;

(3) The name(s) and address (es) of the Special Partnership's General Partner(s);

(4) The total number and value of the Special Partnership's authorized ownership shares, if any.

ARTICLE 152. Partnership Agreement in composition of the Articles of Partnership : 
The Partnership Agreement of Special Partnerships should be signed by all of the Partners. Partners who participate in the preparation of the Articles of Partnership are considered as founders. The founders cannot be fewer than five Partners provided that one of such founder is a Partner. Special Partners who are founders should include in the Partnership Agreement the amount they have agreed to contribute.

ARTICLE 153. Dismissal of Special Partnership Managers:

Managers of Special Partnerships can be dismissed in accordance with the conditions and circumstances determined in ARTICLE 68 of this law.

ARTICLE 154. Involvement of General Partner in the Same Activity:

As in a General Partnership, a General Partner of the Special Partnership cannot engage in a company [Partnership] with a business identical to that of the Special Partnership without the permission of the rest of the General Partners of the Special Partnership or to subscribe in the company as a General Partner. The General Partner violating this is subject to the provisions of ARTICLE 78 of this law. However, if the other General Partners of the Special Partnership, or the Board of Supervisors, have notice of the participation by the General Partner in another company and do not object within one year after receiving notice, they shall be considered to have given permission.

ARTICLE 155. Appointment of Board of Supervisors:

The Special Partners may select a Board of Supervisors which may not include General Partners. The Board of Supervisors shall be responsible for carrying out the decisions made collectively by the Special Partners.

ARTICLE 156. Representation of Special Partners by Board of Supervisors:

The Board of Supervisors can represent the Special Partners in case of a claim between the General Partners and the Special Partners.

ARTICLE 157. Relationship among Partners:

Unless the Partnership Agreement provides otherwise, the relations among Partners is regulated by provisions of this law.

ARTICLE 158. Interference of Special Partners Prohibited into Administrative Affairs:

Special Partners are not authorized to interfere into the administrative affairs of the Partnership and cannot prevent those authorized from executing their duties, but they can vote on transactions not included in the authority of the administrative personnel.

ARTICLE 159. Review and Investigation of Balance Sheet, Papers and Asset Books:

Each Special Partner is allowed at the end of the year to investigate the balance sheet, asset books, and papers of the Special Partnership either personally, or through an informed person. If there is an objection to an opinion made by the informed persons, the informed person may be appointed by the Court on the request of the Special Partner.

ARTICLE 160. Establishment of an Institution whose Subject of Business Constitutes the Activities of Special Partnership:

The contents of ARTICLE 78 if this law are not applicable to Partners of the Special 
Partnership unless one or more of the Special Partners should establish an institution whose activities constitute the subject of the business of the Special Partnership, or join another person having established such an institution, or join an company doing the same business. Such Special Partners will not be entitled to investigate the books and papers of the Special Partnership.

ARTICLE 161. Responsibility Proportional to Capital:

The responsibility of a Special Partner is limited to such Special Partner's promised or paid in capital.

ARTICLE 162. Receiving of the Profit and Dividend by the Special Partner:

The Special Partner can at the end of the fiscal year receive such Special Partner's dividend, or if stated in the Special Partnership Agreement, such Special Partner's interest. If the Special Partnership has suffered a loss, until the loss is recovered, the interest is not paid but in future years, after the loss of capital is made up from remaining profit, the interest of previous years is paid out.

ARTICLE 163. No Return of Dividends:

(1) Special Partners are not required to return interest and divid ends paid in previous years to make up for losses caused thereafter.

(2) Special Partners are not required to return dividends and interest received on the basis of a false or improperly prepared balance sheet.

ARTICLE 164. Legal Representative:

In case of the death of a Special Partner, such Special Partner's legal representative of the heirs replaces such Special Partner.

ARTICLE 165. Transferring Interest of Special Partner, Wholly, or in part, to Another Person:

If a Special Partner transfers, without the permission of other Partners, such Special Partner's interest in the Special Partnership wholly, or in part, to another person, this new Partner is not entitled to investigate or interfere in, the affairs of the Special Partnership.

ARTICLE 166. Liability of Special Partner:

A Special Partner, whose name is in the title of the Special Partnership, has unlimited liability to third persons.

ARTICLE 167. Designation of Special Partner to Transact Business of the Partnership:

The responsibility to administer and represent a Special Partnership rests with the Partners who has unlimited liability. The extent of this authority is subject to the legislative documents that are applicable to General Partnerships. Unless otherwise stated in the Special Partnership Agreement, a Special Partner may be delegated, by the Manager, or Managers, of the Special Partnership, on the consent of such Special Partner, to execute certain transactions. In such cases the liability arising through the execution of such Special Partner's delegated transactions is that of the [Special] Partnership. If a Special Partner acts beyond such Special Partner's delegated duty, or acts without having been delegated, such Special Partner is personally liable for such Special Partner's actions.

ARTICLE 168. Consultation, Right to Investigation and Controlling the Affairs of the Partnership: 
In compliance with the provisions of ARTICLE 159 of this law, the giving of advice and consultations, the right to investigate, and controlling the affairs of the Special Partnership and, participation in the appointment and dismissal of employees in accordance with law, or employment for minor work in the Special Partnership, cannot cause unlimited liability for the Special Partners.

ARTICLE 169. Liability of Special Partners to the Creditors of the Partnership:

The Special Partners are liable, until the time of dissolution of Partnership, to persons to whom the Special Partnership is indebted for the contributions they are obliged to make; or persons to whom the Special Partnership is indebted cannot, during the time that the case is under processing, refer to Special Partners. In the event of dissolution of the Partnership, the creditors have the right to claim against the entire assets of the Special Partnership.

ARTICLE 170. Prioritizing the Claims of Creditors:

In the case of dissolution of a Special Partnership, claims on the Special Partnership are given priority over claims on the Partners personally.

ARTICLE 171. The Equity of Rights of Personal Creditors and Partnership's:

In case the assets of a Special Partnership are not sufficient for the claims against it, creditors can demand their claims from the personal assets of the General Partners. In such cases the creditors of the Special Partnership and the creditors of the General Partners have equal rights.

ARTICLE 172. Demand for Committed Capital:

In case that the assets of the Special Partnership do not satisfy the debts incurred by the Partnership, the Partnership shall be authorized to demand the Special Partner's unpaid committed capital. In this case, the debts of a Special Partnership, as well as the debts of personal creditors, have equal status.

ARTICLE 173. Dissolution and Liquidation of Special Partnerships:

Provisions regarding the Liquidation of General Partnerships apply as well to Special Partnerships.

ARTICLE 174. Creditors of the Partnership:

Where a creditor of the Special Partnership is indebted to a [Special] Partner of such Partnership and the Special Partner has not fulfilled such Special Partner's promises to the Special Partnership, it is possible to apply the debt of the Special Partner against that of the creditor.

\section{CHAPTER 6: WORK PARTNERSHIPS}

ARTICLE 175. Demand for Performance of Work and Demand for Wage by Partners:

Each of the Partners in a Work Partnership shall be deemed a representative of the other Partners in accepting work on behalf of the Work Partnership and the owner of work may demand completion of work from any of the Partners. Conversely, each of the Partners may demand wages from the owner of work and if the owner of work pays the wages for such work to one of the Partners, such payment shall be deemed payment of the wages to all of the Partners. 
ARTICLE 176. Delegation of Work to Others:

Unless otherwise provided in the Work Partnership Agreement, a Work Partner may assign such Partner's work to another Work Partner, or to other persons, unless the owner of work has stated to the Partners that the work must be completed by a specific Work Partner.

ARTICLE 177. Distribution of Profits for the Work Performed:

Profits shall be distributed among the Work Partners as is agreed upon [by the Partners]. In determining the distribution of profits among the Work Partners, the amount of work performed by each Work Partner may be made a condition to the amount of wages paid to each such Partner.

ARTICLE 178. Ensuring Wages of Work:

A Work Partner shall be entitled to a portion of the profits by guaranteeing the performance of the work even though such Partner did not perform the work.

ARTICLE 179. Compensation of Damages Regarding the Work:

Where the work is damaged by one or more of the Work Partners, the owner of work can compel one or more of the Work Partners to compensate the owner of the work for such damages. The loss shall be borne by the Work Partners in accordance with the terms of the Work Partnership Agreement. In the event that there is no Work Partnership Agreement, then the loss shall be borne by the Work Partners in proportion to their share of the profits of the Work Partnership; if the loss is caused by an act of gross negligence of one, or more, of the Work Partners, then the loss shall be borne by the Partners who acted with gross negligence.

ARTICLE 180. Provision of Work Site and Equipment:

In a Work Partnership, some of the Work Partners may provide the work site and other Partners may supply certain work equipment and performance of the work.

\section{CHAPTER 7: MISCELLANEOUS PROVISIONS}

ARTICLE 181. Continuation of Business:

(1) Any partnership which has obtained a business license from the authorized State Authorities, before the effective date of this Law, and which has registered such license at the Administration for Documents and Trademarks, shall there after continue its legal existence and be governed under the provisions of this Law.

Partnership(s) which are not constituted in compliance with this Law shall not be legal Partnership(s).

\section{ARTICLE 182. Paying Tax Duties:}

The Partnerships referred to in this law and their Partners shall be responsible to pay all taxes and any other charges due, in accordance with the provisions of this law.

ARTICLE 183. Enacting Rules, Regulations and Procedures:

For the better implementation of this law, the Ministry of Commerce and Industry propose Regulations and enact relevant Procedures and Rules. 
ARTICLE 184. Effective Date:

This Law is applicable from the date of signing [by the President] and shall be published in the Official Gazette. As of the Effective Date, the provisions of Articles relating to

Partnerships in the Commercial Code published in the Official Gazette \#89, dated Mizan, 1336 and Civil Code dated 15.10.1355 and any other provisions of other laws which contradict the provisions of this law, are voided. 


\section{CORPORATIONS AND LIMITED LIABILITY COMPANIES LAW}

In the Name of Allah, the compassionate, the merciful

\section{CHAPTER 1 GENERAL PROVISIONS}

ARTICLE 01: Purpose

This Law is enacted in light of the Constitution of Afghanistan for regulating the affairs related to the creation and activities of corporations and limited liability companies.

ARTICLE 02: Having License

No person can transact business or advertise as a corporation and limited liability company

in Afghanistan without having a business license registered in the Central Registry.

ARTICLE 03: Scope of Application

The provisions of this Law shall apply to a limited liability company, provided that:

1. The shareholders of the limited liability company are neither less than 2 nor more than 50 persons.

2. Shares of the limited liability company are not purchased or sold in a public stock exchange.

3. The shareholders of the limited liability company are not authorized to sell, transfer or exchange the company.

ARTICLE 04: Definitions

In this Law the following terms shall have the meanings set forth below:

1. "Corporation" is a business company whose capital is definite and divided into

shares, with the share and responsibility of each shareholder limited to the proportion of his share.

2. "Limited Liability company"; "Limited" is a business company whose capital

is not divided into shares with the responsibility of each shareholder limited to

the amount of capital agreed to [by such shareholder] in the company.

3. "Articles of Incorporation": means any document prepared by the founders or shareholders according to provisions of this Law for the purpose of legitimizing their activities. Articles of Incorporation shall include:

(1) The original charter;

(2) 2. All amendments to such charter; [and]

(3) Certificates of merger of two or more companies.

When the Articles of Incorporation have been restated pursuant to any Articles of

Amendment or Merger, it does not include the accompanying Articles of Amendment or Merger.

4. "Authorized Shares" means the Shares that any Domestic or Foreign

Corporation is authorized to issue.

5. "Share" means the unit into which the capital of a Corporation is divided.

6. "Shareholder" means the Person in whose name Shares are registered in the

Central Registry of Shares of the Corporation, and is the beneficial owner of

Shares to the extent of the rights granted in a registered bidding document filed in the Central Registry of the Corporation, or the beneficial owner of Shares, who assigns his voting rights to a third party [owner of shares held in a Voting Trust].

7. "Share Class" means a group of similar shares which confer the same rights on the holders of such shares [the shareholders].

8. "Dividend" means a part of the company's net earnings that are distributed to Shareholders in accordance with the rights determined for each kind and class of shares.

9. "Redeemable Share" means a Share that may be redeemed at the option of the Shareholder.

10. "Capital Stock" means the total par value (face value) of all shares offered by the company.

11. "Reserved Capital" means the total capital collected for each single share of the

company from the beginning to the end. [sec]

12. "Certification" means the verification of the Central Registry concerning 
effectiveness of the Articles of Incorporation, which is issued upon registering it at the Central Registry. 13. "Derivative Action" means any civil proceeding by a Shareholder on behalf of the interests of the Corporation.

14. "Central Registry" means the agency for registering the documents related to domestic and Foreign Corporations.

15. "Commercial Court" means the authorized Commercial Court of Afghanistan.

16. "Domestic Corporation" means for the purpose of this Law a Corporation that:

- is authorized by law to issue shares, irrespective of the nature of [its] business,

- is organized under this Law or existing pursuant to the previous laws of Afghanistan,

- by virtue of Articles of Incorporation, Amendment, or merger, has

become a domestic Corporation. A foreign Corporation organized

under laws of foreign companies that operate in Afghanistan shall be

subject to the provisions of this Law.

17. "Electronic Transmission" means any form of communication, not directly

involving the physical transmission of paper that creates a historical record that

may be retained, retrieved and reviewed by a recipient thereof, and that may be

directly reproduced in paper form by such a recipient.

18. "Right of Pre-emption" means the right of Shareholders to maintain their stock

ownership through purchase of additional Shares and securities that may be

converted to issues of Shares, prior to any offer of them to third parties.

19. "Right of Preference" means the right devoted by the Articles of Incorporation

to a group of Shares which provide the Shareholders with the same rights.

20. "Voting Trust" means transferring to or conferring on a trustee the right to vote.

21. "Employee" means an officer or person employed by a Corporation or its

affiliated entities to perform duties related to the company. A Director may

simultaneously perform duty as an officer.

22. "Entity" can be a

- Natural domestic person - which is a person having Afghan citizenship;

- Domestic legal person - which is an organization, company, proprietary

ownership, limited liability company, temporary partnership, temporary

investment company, association, or any other for-profit organization,

which is established according to the provisions of law;

- Foreign natural person -which is a person that has non-Afghan citizenship;

- Foreign legal person -which is a person whose legal existence is defined under non-Afghan laws.

23. Head Office" means the office, in or out of Afghanistan, where the principal

executive offices of a Domestic or Foreign Corporation are located, or, if there

are no such offices, the office, in or out of Afghanistan, so designated by the

Board of Directors. The designation of the principal office in the most recent

Annual Report shall be regarded as the Head Office for the purposes of this Law.

\section{CHAPTER 2 \\ REGISTRATION REQUIREMENTS FOR CORPORATIONS}

ARTICLE 05: Registration of Documents:

(1) The following documents may be registered in the Central Registry office:

1. The written documents which contain the information specified by this law;

2. The documents typewritten or printed in black;

3. Documents that may be copied;

4. Documents that are legible;

5. Document prepared in one of the official languages (Pashto or Dari).

(2) The Articles of Incorporation of Foreign companies may be in a foreign

language, provided that it is accompanied by an accurate Dari or Pashto translation.

ARTICLE 06: Preparation of Documents:

The document of a Corporation shall be prepared by the following persons: 
1. By Officer(s) authorized to execute action on behalf of the Corporation;

2. The Board of Directors of the Corporation;

3. One or more incorporators of the Corporation;

4. The receiver, Trustee, or other Court-appointed fiduciary.

ARTICLE 07: Preparation of the Annual Report:

Annual reports shall be prepared by an officer or Director of the company and shall be registered in accordance with this Law.

ARTICLE 08: Certification of the Seal and Signature:

The Person executing the document shall sign it and state beneath or opposite his signature his name and the capacity in which he signs. Any signature may be a facsimile. The signature and corporate seal shall be attested and verified by the secretary or an assistant secretary.

ARTICLE 09 Preparation of special forms:

If, required pursuant to any provision of this Law, the Central Registry may prepare a document in a special form.

ARTICLE 10: Payment of the Fee:

The document delivered to the Central Registry for registration shall be registered when the applicable filing fee is paid in accordance with this law.

ARTICLE 11: Electronic Registration:

The Central Registry may accept the electronic registration of any information permitted by this Law and may prescribe the methods of execution, recording, reproduction and certification of electronically filed information.

ARTICLE 12: Correcting Articles of Incorporation :

(1) The Board of Directors of a Corporation may authorize correction of any Articles of Incorporation filed with the Central Registry ;

(2) Correction of Articles of Incorporation referenced in paragraph (1) of this Article may be made when: (i) it contains an incorrect statement; (ii) it is defectively executed, verified, certified, signed or sealed.

(3) Upon the issuance of a Certificate of Correction mentioned in paragraph (2) of this Article, the Articles of Correction shall be filed together with the effective date of the correction .

(4) No Articles of Correction shall be accepted by the Central Registry when received more than ten days after the effective date of the Certificate relating to the Articles of Incorporation to be corrected.

\section{CHAPTER THREE ISSUANCE OF REGISTRATION CERTIFICATE}

ARTICLE 13: Issuance of Certificate:

The Central Registry can only issue a certificate if the document has been prepared and registered according to the provisions of this law.

ARTICLE 14: Certificate of Existence:

(1) Anyone may apply to the Central Registry to furnish a Certificate of Existence

for a Domestic or Foreign Corporation. The Certificate may state any other

facts of record with the Central Registry that are requested by the applicant.

(2) The Certificate of Existence of the Corporation includes the following:

1. Activity of the Corporation in Afghanistan;

2. That the Corporation has not dissolved or has not terminated its activities;

3. The name of the Domestic or Foreign Corporation as it is registered in Afghanistan;

4. The date of the establishment of the Corporation and the period of its

duration if for a limited period; 
5. That the Foreign Corporation is authorized to transact business in Afghanistan;

6. The date of registration of the Articles of Incorporation in the Central Registry.

ARTICLE 15: Requirement of the Existence of the Corporation:

(1) Foreign or Domestic Corporations in Afghanistan shall be deemed to be in existence under the following terms:

1. Having a business license;

2. Payment of all fees, fines, penalties and interest in accordance with the provisions of this Law;

3. Filing annual reports with the Central Registry in accordance with this law;

4. No dissolution or withdrawal of activities.

5. If the Corporation does not meet the above-mentioned requirements, the Central Registry shall certify the dissolution or termination of the activities of the Corporation.

6. A Certificate of Existence issued by the Central Registry shall be regarded as

conclusive evidence that the Domestic or Foreign Corporation is in existence as a Corporation.

\section{CHAPTER FOUR PAYMENT OF FEES}

ARTICLE 16: Fees to be Collected:

The Central Registry shall collect the registration fees imposed by this law and transfer the money to the income account of the State and assure the relevant authority that this money is paid.

ARTICLE 17: Effective Date of the Certificate:

1. A Certificate issued by the Central Registry is effective at the time such Certificate is issued unless the Articles of Incorporation provide otherwise.

2. Any other document filed with the Central Registry shall be effective when accepted and filed by the Central Registry unless otherwise provided for in this Law. 3. Any Certificate that has a delayed effective date shall be deemed to be effective when the Certificate is issued.

4. When a Certificate has a delayed effective date and the parties which filed this Certificate request a cancellation, and the Central Registry registers that, such Certificate shall become void.

\section{CHAPTER FIVE PROCEDURES FOR ESTABLISHMENT OF ACORPORATION}

ARTICLE 18: Establishment of a Corporation:

A Domestic Corporation is established for any lawful business in accordance with this law and the relevant Articles of Incorporation, whose capital is definite and divided into Shares, with the responsibility of each Shareholder limited to the value of his or her Share.

ARTICLE 19: Activities of the Corporation:

Unless its Articles of Incorporation provide otherwise, every Corporation has perpetual duration and has the same powers as an independent Entity which operates legally to execute business transactions and other affairs.

ARTICLE 20: Incorporators:

One or more Persons may act as the Incorporator by signing and filing Articles of Incorporation with the Central Registry.

ARTICLE 21: Articles of Incorporation:

(1) The Articles of Incorporation must include the following:

1. The name of the Corporation;

2. The name and address of each Incorporator and Director; 
3. The address of its Registered Office in Afghanistan and the name of its responsible agent at such office;

4. The number and types of Shares the Corporation is authorized to issue;

5. The duration of the Corporation, which duration will be assumed to be

infinite unless otherwise limited in the Articles of Incorporation.

(2) The Articles of Incorporation may include the following, as well as terms mentioned in Article 20(1) above:

1. Any provision defining or denying the priority right of Shareholders to acquire unissued Shares of the Corporation;

2. The purpose for which the Corporation was organized;

3. Par value for Capital Stock;

4. Limiting the liability of Directors;

5. Any provision otherwise required which is not against the provisions of this law.

ARTICLE 22: Signing the Articles of Incorporation:

(1) Corporate existence begins when the Articles of Incorporation are signed by the Incorporators or a person to whom the power to sign has been delegated by agreement, and the Articles have been registered with the Central Registry .

(2) Notice of the formation of a Corporation, including the name and registered address of the Corporation, shall be advertised in accordance with the law.

ARTICLE 23: Pre-Incorporation Activities:

All Persons purporting to act on behalf of a Corporation prior to its establishment shall be liable for all liabilities created while so acting, except for any liability to any Person who knew that there was no Corporation formed under this Law.

ARTICLE 24: Activities of the Board of Directors:

(1) The Board of Directors can start their activities after establishment of the Corporation and can hold their meetings inside or outside Afghanistan according to the provision of this law.

(2) According to the provisions of this law, incorporators of the Corporation can hold their meetings inside or outside Afghanistan.

(3) According to the provisions of this law, the incorporators of a Corporation can make decisions without holding meetings if the action taken is evidenced by a written consent signed by each incorporator.

\section{CHAPTER SIX}

\section{BY-LAWS}

ARTICLE 25: Enacting By-Laws

The incorporators or Board of Directors, of a Corporation may adopt by-laws to better implement the relevant Articles of Incorporation, provided that it is not inconsistent with this law or the Articles of Incorporation.

ARTICLE 26: Corporate Name:

A corporate name shall contain the word "corporation", "incorporated", "company", or "limited", or the abbreviation "Corp.", "Inc.", "Co.", or "Ltd."

ARTICLE 27: Prohibited Corporate Names:

The Incorporators cannot select the following names for their corporation:

1. A corporate name that is prohibited by law for a Corporation;

2. A name that has been selected and registered with the Central Registry for another

Corporation;

3. A name of a Foreign Corporation, unless the selected name can be distinguished from the foreign name.

ARTICLE 28: Maintaining a Business Office:

Each Corporation in Afghanistan shall: 
1. Have a business office that has been registered with the Central Registry.

2. Have a responsible agent at the location of the registered office. The

registered agent may be an individual Person or a Domestic Corporation.

ARTICLE 29: Obligations of the Agent:

1. The duty of the registered agent is to receive service of any process, notice or demand on behalf of the Corporation that is required or permitted by law to be served on the Corporation, and to forward the goods provided through him to the Corporation at its last known address.

2. Whenever a claim is made against a Corporation and its registered agent can not be found at the registered office, then the responsible person shall be found and searched on the basis of the Central Registry.

\section{CHAPTER SEVEN ISSUANCE OF SHARES}

ARTICLE 30: Issuance of shares for consideration:

A Corporation may issue its Shares of Capital Stock when authorized by the Board of Directors for consideration, consisting of any tangible or intangible property, or benefit to the Corporation, including cash, commitment for services that have been performed or contracts for services to be performed.

ARTICLE 31: Receiving consideration for shares:

If the Board of Directors determines, in good faith, that the consideration received, or to be received, for the Shares to be issued is adequate, such determination is conclusive and final regarding the adequacy of consideration as far as the Shares are validly issued and fully paid. When the Corporation has received the payment for the Shares, the Shares issued therefore are fully paid.

ARTICLE 32: Offer of Shares:

Shareholders of a Corporation wishing to issue their Shares to the public may do so in accordance with rules established by the Central Registry or other competent authorities.

\section{CHAPTER EIGHT BOARD OF DIRECTORS}

ARTICLE 33: Board of Directors of a Corporation:

(1) The Corporation shall have a Board of Directors, which according to the Articles of Incorporation, By-Laws, and agreements of the Shareholders is an authorized Board to direct and regulate the affairs of the Corporation.

(2) The Board of Directors shall have the power to represent the Corporation and execute any legal document subject to any limitations set forth in the Articles of Incorporation.

ARTICLE 34: Selection Requirements for members of the Board of Directors:

(1) A person may only be selected as a member of a Board of Directors with the following qualifications:

1. Natural persons who are eighteen (18) years of age ;

2. Persons that have never been deprived of civil rights by a court order;

(2) The Board of Directors may be composed of one or more members. The minimum and maximum number of members and other relevant conditions shall be stipulated in the Articles of Incorporation or the By-Laws of the company.

ARTICLE 35: Appointment of the members of the Board of Directors:

(1) Directors shall be elected by the Shareholders at each Regular/Annual Shareholder's Meeting, in accordance with the Articles of Incorporation .

(2) The Articles of Incorporation, or By-laws, may authorize the Shareholders, or the 
Board of Directors, to fix or change the number of Directors.

ARTICLE 36: Term of Directors:

(1) The terms of the Initial Directors of a Corporation expire at the first

Shareholders' Meeting at which Directors are elected.

(2) The terms of Directors shall be for the length determined by the Shareholders, not to exceed three years.

(3) A Director elected to fill a vacancy on the Board of Directors shall serve for the unexpired term of his predecessor in office.

(4) If there shall be an increase in the number of Directors, the new members of the Board shall be elected, but only for a term of office continuing until the next election of Directors.

(5) Despite the expiration of a Director's term, he continues to serve until his successor is elected and qualifies, or until there is a decrease in the number of Directors.

ARTICLE 37: Resignation of a Director:

A Director may resign at any time by delivering written notice to the Board of

Directors, its Chairman, or to the Corporation. A resignation is effective on the date of notice.

ARTICLE 38: Dismissal of a Member of the Board of Directors:

(1) The Shareholders, by majority vote, may remove one or more Directors, with or without cause, unless the Articles of Incorporation, or By-laws, provide otherwise.

(2) One or more Directors may be removed by the Shareholders at a Special

Meeting called for the purpose of removing him, which includes the matter in the agenda.

ARTICLE 39: Election of a Chairman:

Each year the Members of the Board of Directors shall elect from among themselves, a

Chairman of the Board, unless required otherwise by the Articles of Incorporation, or the By-laws.

ARTICLE 40: Vacancy on the Board:

(1) Unless the Articles of Incorporation, or By-laws, provide otherwise, if a vacancy occurs on a Board of Directors, including a vacancy resulting from an increase in the number of Directors, the Board of Directors may fill the vacancies, the term of which shall be the unexpired term of such vacant position. (2) A vacancy that will occur at a specific later date (by reason of a resignation effective at a later date or otherwise) may be filled by the Board of Directors before the vacancy occurs, but the new Director may not take office until the vacancy occurs.

ARTICLE 41: Power of the Board of Directors:

Subject to the limitations within the Articles of Incorporation, the Board of Directors is entitled to execute and sign any legal document and to represent the Corporation in legal transactions.

ARTICLE 42: Holding Meetings:

(1) The Board of Directors may hold Regular/Annual or Special Meetings in any location.

(2) Unless the Articles of Incorporation, or By-laws, provide otherwise, the Board

of Directors may permit any, or all, the Directors to participate in a

Regular/Annual or Special Meeting by any means of communication by

which all Directors participating may simultaneously hear each other during

the meeting, including through the use of telephone or video conference. A

Director participating in a meeting by this means is deemed to be present in person at the meeting.

ARTICLE 43: Actions without Holding a Meeting:

(1) Unless the Articles of Incorporation, or By-laws, provide

otherwise, action required to be taken at a Board of Director's 
meeting shall be valid when taken without a meeting if the action is taken in writing by all members of the Board.

(2) The action of the Board of Directors mentioned in paragraph

(1) of this Article and the minutes of the meeting shall be filed with the Corporation records. Such action shall be regarded as voting in the meetings of the Board. The action has the effect of a vote at a meeting of the Board of Directors.

ARTICLE 44: Notice of Meeting:

(1) Unless the Articles of Incorporation, or By-laws, provide otherwise, notice of the date, time and place of Regular/Annual or Special Meeting(s) of the Board of Directors shall be given to members of the Board of Directors no fewer than two days prior to such meeting.

(2) A Director may waive any notice required by paragraph (1) of this Article, in compliance with the Articles of Incorporation, or By-laws, before, or after, the date and time stated in the notice. The waiver must be in writing, signed by the Director entitled to the notice, and filed with the corporate records.

(3) A Director's attendance at, or participation in a meeting acts as a waiver of any required notice to him, unless the Director at the beginning of the meeting (or promptly upon his arrival) objects to holding the meeting and does not thereafter vote on any proposal at the meeting.

ARTICLE 45: Quorum and Decisions by Meetings:

(1) A quorum of the meeting is complete by a majority of the number of Directors.

(2) Decisions are taken in Board of Director's meetings by a majority of the variable number of Directors, unless the Articles of Incorporation and By-laws provide otherwise.

ARTICLE 46: Committees:

(1) Unless the Articles of Incorporation or By-laws does not provide so, a Board of Directors may create one or more committees to perform the relevant affairs and appoint members of the Board of Directors to serve on them, and may delegate authority to such committees to act on behalf of the Board of Directors. Each committee may have one or more members, who serve for the period determined by the Board of Directors.

(2) The provisions of this Law that govern the Board of Directors, also apply to committees and their members.

(3) A Committee may not:

1. Perform the functions and exercise powers related to shareholders;

2. Appoint any person to fill a vacancy on the Board of Directors, or on any committee;

3. Propose the amendment or adoption of Articles of Incorporation, or Bylaws;

4. Approve a plan of merger or dissolution of the Corporation .

ARTICLE 47: Responsibility of Directors:

(1) A Director shall have the following duties:

1. To ensure the best interest of the Corporation and its Shareholders;

2. To discharge assigned duties with due diligence.

(2) In discharging his duties mentioned in paragraph (1) of this Article, a Director

is entitled to rely on information, opinions, reports, or statements, including

financial statements, and other financial data, when he wants to make sure that they are prepared and presented by:

1. One or more officers or employees of the Corporation whom are reliable;

2. Legal counsel, accountants, bankers, or other persons who are professional and with expert competence;

3. A committee which merits confidence, even if not included in the Board of Directors.

(3) In instances described in paragraph (2) of this Article, a Director is not

entitled to rely on information which is not true or persons that makes reliance unwarranted. 
(4) If the member of the Board of Directors does not perform his duties in good faith and according to paragraphs (1) and (2) of this Article, he/she is responsible to the Corporation and the shareholders.

ARTICLE 48: Derivative Actions:

(1) A Derivative Proceeding may be brought by a Shareholder in the right of a

Corporation against one or more of its Directors, or Officers, in the event of the

failure to perform, or other violation of their duties in management of the Corporation.

(2) A Shareholder may not commence a Derivative Proceeding unless he was a

Shareholder at the time of the act or omission that is the subject of his

complaint, and he fairly represents the interests of the Corporation.

Derivative Proceedings may not be commenced more than four years from

the time the cause of action occurred.

(3) Prior to commencing a Derivative Proceeding, a Shareholder must first make

written demand on the Corporation requesting that it take suitable action.

The Corporation shall respond within 90 days following such a request by

either commencing the requested action or by rejecting the request, provided

that it may be commenced prior to the date that material harm to the

Corporation would likely result.

(4) This ARTICLE 47 shall not limit any liability otherwise imposed by law upon

any Director or Officer, or any third party.

ARTICLE 49: Unlawful Distributions of Corporate Assets:

(1) Directors who engage in distribution of the Corporation's assets in violation

of ARTICLE 99, or the Articles of Incorporation, are personally liable.

Directors held liable hereunder shall demand reimbursement from each

Shareholder for the amount the Shareholder accepted, if such Shareholder

knew the distribution was unlawful.

(2) A Shareholder that has incurred a loss due to the illegal distribution mentioned

in paragraph (1) of this Article may file a claim within two years.

ARTICLE 50: Conflict of Interest in Transactions:

(1) If a member of the Board of Director s has a conflict of interest in a business

transaction, he must disclose the matter to the Board of Directors of the

Corporation. Otherwise he will be responsible.

(2) "Conflicting Interest" with respect to a Corporation means: the interest of a

Director of the Corporation in a transaction effected, or proposed to be

effected by the Corporation (or by a subsidiary of the Corporation), where the

Director at the time of commitment, or his related person, is a party to the

transaction or has beneficial financial interest in the transaction, that exerts a

financial influence on the Director or his related person.

(3) "Director's Conflicting Interest Transaction" with respect to a Corporation

means: a transaction effected, or proposed to be effected, by the

Corporation (or by a subsidiary of the Corporation, or any other Entity in

which the Corporation has a controlling interest) respecting which a

Director of the Corporation has a Conflicting Interest.

(4) "Related person" of a Director means the spouse, parent, brother, sister,

child, grandchild, sibling (or spouse of any thereof) of a Director, or an individual having the same home

as the Director, or a trust, estate, incompetent, conservatee or minor of which the Director is a fiduciary.

(5) "Disclosure" according to paragraph (1) if this Article means: disclosure

by the Director who has a Conflicting Interest where the existence and

nature of the disclosure relates to him, and disclosure of all the facts that the

Director has already known concerning the subject matter.

ARTICLE 51: Judicial action:

(1) A transaction shall be effected, or proposed to be effected, by a Corporation 
(or by a subsidiary of the Corporation or by any other controlled Entity) when it is not a Director's Conflicting Interest Transaction as defined in Article 50 of this law, is not prohibited or enjoined by the court in an action by a Shareholder, or a Derivative Proceeding based on such Director's interest in the transaction, and is not sentenced to payment of damages or to other limitations. [Sec]

(2) A Director's Conflicting Interest Transaction may not be enjoined by the court or set aside, or give rise to an award of damages, or other sanctions in an action by a Shareholder or a Derivative Proceeding unless:

1. Shareholders' approval relating to the transaction was, at any time, taken in compliance with ARTICLE 53;

2. The transaction, judged in the circumstances at the time of commitment, is established to have been fair to the Corporation.

ARTICLE 52: Directors' Approval:

(1) Directors' approval regarding a transaction is effective if the transaction received the affirmative vote of a majority of the Qualified Director s or after required disclosure in compliance with this ARTICLE.

(2) If a Director has a Conflicting Interest respecting a transaction, but neither he nor a related Person is a party thereto, and if the Director has a duty under law, or a duty of confidentiality to another person regarding information relating to the transaction such that the Director cannot, consistent with that duty, make the required disclosure, then disclosure is sufficient for these purposes if the Director: 1. Discloses to the Directors voting on the transaction the existence and nature of his Conflicting Interest and informs them of the character of, and limitations imposed, by that duty, prior to their vote on the transaction; and 2. Does not, directly or indirectly, participate in the discussion, vote. (3) Qualified Directors who constitute a quorum hereunder, have no conflict of interest in the transaction and neither have a familial, financial, professional or employment relationship with another Director who does have a conflict of interest .

ARTICLE 53: Shareholder s' Approval:

(1) Shareholder s' approval regarding a transaction is effective for purposes of Article 51(2)2, if approved by a majority vote of all Qualified Shareholders after disclosure. (2) Qualified Shares means any Shares the holders of which are entitled to vote with respect to a Director 's Conflicting Interest Transaction, except Shares owned by a Director (or a Related Person) with a Conflicting Interest in such transaction.

ARTICLE 54: Preparation and Delivery of Financial Statements:

(1) Not less than 15 days prior to the Regular/Annual Meeting of the Shareholders, the Corporation shall deliver to all of the Shareholders entitled to attend such Meeting Financial Statements dated as of the last day of the fiscal year of the Corporation, which shall include the balance sheet dated as of the last day of the fiscal year and the profit and loss statement of the Corporation for the fiscal year. All Financial Statements shall include all operations of the company and shall comply in all material respects, with the applicable accounting standards set forth by the International Accounting Standards Board. (2) The Financial Statements, as well as the Corporation's books and records, shall be made available to all Shareholders for investigation at the Corporation's main office not less than 15 days prior to the Regular/Annual Meeting of the Shareholders.

ARTICLE 55: Rights and Privileges:

Unless the Articles of Incorporation or By-laws provide otherwise, the Board of Directors may set the compensation of Directors, subject to approval by the Shareholders.

ARTICLE 56: Maintaining Corporate Records: 
The Board of Directors, in addition to keeping required commercial books, must also keep the following records:

1. A Shareholders' registry in which the name, address and number of owned

Shares of each Shareholder are recorded;

2. A record of initial payments made for capital and the increases therein;

3. A record of the minutes of meetings of the Shareholders and the Board of Directors;

4. The Financial Statements, as presented annually to the Shareholders.

ARTICLE 57: Appointment of Officers:

(1) Unless otherwise provided in the Articles of Incorporation, or By-laws, the

Board of Directors may appoint officers of the Corporation.

(2) The Officers shall have the grades, terms, duties and responsibilities as

determined, from time to time, by the Board of Directors.

(3) Officers who are not Shareholders may simultaneously hold more than one

office, and may also be a member of the Board of Directors.

ARTICLE 58: Indemnification:

(1) any person who is a party to any action or suit, whether civil, criminal, administrative or investigative (other than a Derivative Proceeding) by reason of the fact that the person is, or was a Director, officer, employee or agent of the Corporation, shall be indemnified by the Corporation against expenses (including attorneys' fees), judgments, fines and amounts paid in settlement that are actually and reasonably incurred by such person in connection with such action, suit, or Proceeding if the person acted in good faith, and in a manner which is in the best interests of the Corporation, and, with respect to any criminal action or Proceeding, had no reasonable cause to believe the person's conduct was unlawful. (2) A Corporation shall have power to indemnify any person who is, was, or is threatened to be made a party to any Derivative Proceeding, or suit by, or in the right of, the Corporation by reason of the fact that the person is, or was a Director, officer, employee, or agent of the Corporation, against expenses (including attorneys' fees) incurred by such person in connection with the defense, or settlement of such action, or suit, if the person acted in good faith and in a manner which is in the best interests of the Corporation, shall be an exception to this rule [sec]. (3) To the extent that a present, or former Director, or officer of a Corporation has been defending in an action, suit, or proceeding referred to in this ARTICLE, such person shall be indemnified against expenses (including attorneys' fees) incurred by such person. (4) Expenses (including attorneys' fees) incurred by an officer or Director in defending any civil, criminal, administrative, or investigative action, suit, or proceeding may be paid by the Corporation prior to the final disposition of such action, suit, or proceeding, upon receipt of an undertaking by, or on behalf of, such Director or officer to repay such amount if it shall ultimately be determined that such person is not entitled to be Indemnified by the Corporation as authorized in this ARTICLE 57. Such expenses (including attorneys' fees) incurred by such person(s) may be so paid upon such terms and conditions, if any, as the Corporation deems appropriate.

(5) The Indemnification and advancement of expenses pursuant to this ARTICLE shall not be deemed exclusive of any other rights to which those seeking Indemnification, or advancement of expenses, may be entitled under any charter, Agreement, vote of Shareholder s, or disinterested Directors, or otherwise. A Corporation may purchase insurance on behalf of any Director, officer; employee, or agent of the Corporation against any liability asserted against, or incurred by , such person those acting in capacities.

(6) The advancement of expenses provided by this ARTICLE shall, unless otherwise provided when authorized, continue as to a person who has ceased to be a Director, officer, employee, or agent and shall inure to the benefit of the heirs, executors and administrators of such person. 


\section{CHAPTER NINE BOARD OF SUPERVISORS}

ARTICLE 59: Electing the Board of Supervisors:

(1) The Board of Supervisors of the Corporation shall be composed of two or

more members, that shall be elected by the Shareholders at the

Regular/Annual Meeting of Shareholders, unless provided otherwise in

Articles of Incorporation or the By-laws. If appointed in the Articles of

Incorporation, the first term shall be for one year, and thereafter for a

maximum period of three years. The Board of Supervisors whose term has expired may be re-elected.

(2) Members of the Board of Supervisors cannot also be members of the Board of

Directors nor can they administer the business operations of the Corporation.

ARTICLE 60: Dismissal:

Members of the Board of Supervisors can, at any time, be dismissed by the Shareholders. A

member who is a Shareholder cannot ask for damages or other compensation related to his dismissal.

ARTICLE 61: Vacancies on the Board of Supervisors:

If a member of the Board of Supervisors cannot, for any reason, execute his duties or otherwise resigns, other members of the Board of Supervisors may appoint another member to fill such vacancy until the next Regular/Annual Meeting of the Shareholders. In case the Board should be composed of two members, the vacancy should be filled until the next meeting of the Board of Directors.

ARTICLE 62: Committees:

The Board of Supervisors may appoint one or more committees consisting of two or more members of the Board of Supervisors, in order to investigate certain specific matters.

ARTICLE 63: Prohibition on Appointment of Relatives as Members of the Board of Supervisors: Relatives of Members of the Board of Directors, such as a father, mother, brother, son, daughter, uncle, aunt, father-in-law, mother-in-law, or son-in-law, cannot be elected as members of the Board of Supervisors.

ARTICLE 64: Duties of the Board of Supervisors:

The following are the duties of the Board of Supervisors:

1. Cooperation with the Board of Directors in preparation and review of, the financial statements of the Corporation;

2. Investigation of the operations and books of the Corporation at least

once every six months;

3. Inspection, without notice, of the treasury of the company at least once every three months;

4. Supervision of the actions of the Board of Directors with regard to the provisions of this law and as prescribed by the Articles of Incorporation and By-laws;

5. Notice of Regular/Annual or Special Meetings of the Shareholders if

such duties are not fulfilled by the Board of Directors; and

6. Attendance at General Meetings of Shareholders;

7. To call Special Meetings of the Shareholders in cases of importance or emergency.

8. The Board of Supervisors must present to the Regular/Annual Meeting

of Shareholders the result of its reviews of the financial statements and

other accounts of the Corporation and the distribution of profits.

ARTICLE 65: No Limitation of Authority for the Board of Supervisors:

The authority of the Board of Supervisors as set forth herein cannot be limited in the Articles of Incorporation or the By-laws. 
ARTICLE 66: Execution of Duties by the Board of Supervision in Good Faith:

(1) The Board of Supervisors shall execute its duties in good faith and in the best interests of the Corporation and its Shareholders.

(2) The Board of Supervisors shall supervise the conduct of and

implementation of actions and responsibilities by the Board of Directors.

(3) The bringing of a case against the Board of Supervisors for misconduct

is invalid five years after the date of the action or inaction in question .

ARTICLE 67: Complaint against the Board of Directors:

Shareholders may refer to the Board of Supervisors any complaint against the Board of

Directors of the Corporation, which shall properly investigate all such complaints and take

all reasonable and appropriate action required as a result of such matter.

ARTICLE 68: Participation by the Board of Supervision in Meetings of the Board of Directors The Board of Supervisors may attend and participate in Meetings of the Board of Directors, but shall not be entitled to vote.

\section{CHAPTER TEN SHAREHOLDER MEETINGS}

ARTICLE 69: General Meetings of the Shareholders:

(1) Meetings of the Shareholders of the Corporation may be either Regular /Annual or Extraordinary [Special]. The Regular/Annual Meeting is to take place within four months after the end of the Corporation's fiscal year, or at such other time as is provided for in the Corporation's Articles of Incorporation, provided, however, that the Regular/Annual Meeting shall be convened at least once each calendar year.

(2) The Regular/Annual Meeting shall be held at the Corporation's principal office, or at such other place as may be designated by the Board of Director s, either within or outside of Afghanistan. The Board of Directors may determine the place for a Meeting. When needed, the meetings may be held by means of remote c ommunication as permitted in this Law.

(3) The failure to hold the Regular/Annual Meeting at the time or place stated in the Articles of Incorporation does not affect the validity of any action by the general meeting of the Shareholders.

ARTICLE 70: Remote Communication:

If authorized by the Articles of Incorporation, the By-laws, or the Board of Directors, and subject to such guidelines and procedures as the Board of Directors may adopt, Shareholders and proxy holders not physically present at an Regular/Annual Meeting may, by means of remote communication such as telephonic or video conference participate in an Regular/Annual or Special Meeting and be deemed present in person and vote at such Meeting.

ARTICLE 71: Extraordinary [Special] Meetings:

(1) A Corporation shall hold a Special Meeting of the Shareholders:

1. On the call of its Board of Directors or the person or persons authorized to

do so by the Articles of Incorporation or By-laws; or

2. If Shareholders controlling at least 10 percent of the votes entitled to be cast on an issue request, in writing, a Meeting of the Shareholders. The request must be signed and dated by the requesting Shareholder, or Shareholders, and must describe the purposes for which the Special Meeting will be held. A Corporation's Articles of Incorporation may fix a lower percentage, or a higher percentage not exceeding 25 percent, of all of the votes entitled to be cast. (2) The only matters to be discussed and voted upon at the Special Meeting are such matters as are included in the notice of the Meeting.

(3) The record date for determining qualified Shareholder s entitled to demand a 
Special Meeting is as determined by the administration of the Corporation.

Such invitation shall be on the date the last Shareholder signs the request for a Special Meeting.

(4) Special Meetings may be held at the place established in the By-laws, or as

determined by the Board of Directors, including participation by remote

communication as provided in this law.

ARTICLE 72: Court-Ordered Meeting:

(1) The Commercial Court may call a Meeting of the Shareholders in the following cases:

1. Any Shareholder of the Corporation entitled to participate in

Regular/Annual Meetings, if such Meeting was not held within four

months after the end of the Corporation's fiscal year, in accordance

with Article 69 (1) of this law;

2. A Shareholder who made a valid request for a Special Meeting, if

pursuant to ARTICLE 71 paragraph (1), section 2, the Special Meeting was not held.

ARTICLE 73: Decisions without a Meeting:

(1) Action required, or permitted, by provision of this law to be taken at any

Meeting of the Shareholders may be taken without a Meeting if the action is

taken in writing by the Shareholders entitled to vote on the action as set forth herein. The action must be submitted in writing, dated and signed to the Shareholders owning at least the number of Shares required. If a written action is taken by fewer than all the Shareholders, written notice of the action taken shall be sent promptly to all Shareholders. All written actions, as set forth herein, shall be delivered to the Corporation for inclusion in the Minutes, or filing with the corporate records. If not otherwise set, the Record Date for determining Shareholders entitled to take action Without a Meeting is the date the first Shareholder signs the written action. Written actions shall be effective to take the corporate action referred to therein, provided, that if the written action is taken by less than all of the Shareholders as provided in paragraph (1) of this ARTICLE and/or the notice of such proposed action is required to be given to any nonvoting Shareholders, such written actions may be effective no earlier than 20 days after notice of such action is delivered to Shareholders. A Shareholder may revoke his consent to a written action by delivering a revocation in writing to the Corporation prior to receipt by the Corporation of written consents sufficient in number to take the proposed corporate action. A written action under paragraph (1) of this ARTICLE has the effect of a Meeting vote and may be described as such in any document. (2) Any notices and consents required to be delivered under this ARTICLE may be delivered via Electronic Transmission .

ARTICLE 74: Notice of Meeting:

(1) The notice of a Meeting of the Shareholders is to be given as provided in the Corporation's Articles of Incorporation, or By-laws, provided, however, that the Corporation shall notify Shareholders of the date, time and place of each Meeting, and the means of remote communication, if any, no fewer than 10 nor more than 60 days before an Regular/Annual Meeting date and no fewer than five days before a Special Meeting date. The Corporation is required to give notice only to those Shareholders entitled to vote at the Meeting.

(2) If not otherwise set by the Board of Directors in the By-laws, the Record Date for determining Shareholders entitled to notice of and vote at a

Regular/Annual or Special Meeting is the day before the first notice is delivered to the Shareholders.

(3) Unless the Corporation's Articles of Incorporation or By-laws specify otherwise, if an Regular/Annual or Special Meeting is adjourned to a different time, date or place, notice need not be given of such new time, date or place if the new time, date or place is announced at the Meeting prior to 
adjournment. If a new Record Date for the adjourned Meeting is fixed, notice of the adjourned Meeting must be given to Persons who are Shareholders of Record as of the new Record Date.

ARTICLE 75: Method of Invitation:

(1) Without limiting the manner by which notice otherwise may be given to Shareholders, any notice to Shareholders given by the Corporation (as provided in this Law, the Articles of Incorporation, or the By-laws) shall be effective if given by a form of Electronic Transmission (including electronic mail) consented to by the Shareholder to whom the notice is given. Any such consent shall be revocable by the Shareholder by written notice. Any such consent shall be deemed revoked if the Corporation is unable to deliver by Electronic Transmission two consecutive notices.

(2) The Board of Directors may decide concerning the notice referred to in paragraph (1) of this Article if the written agreement and signature by other members of the Board of Directors have been received by electronic transmission.

(3) Notice given pursuant to paragraph (1) above, shall be deemed given: 1. if by facsimile telecommunication, when directed to a number at which the Shareholder has consented to receive notice;

2. if by electronic mail, when directed to an electronic mail address at which the Shareholder has consented to receive notice;

3. if by a posting on an electronic network together with separate notice to the Shareholder of such specific posting, upon the later of: (i) such posting, and

(ii) the giving of such separate notice; or

4. by any other form of Electronic Transmission, when directed to the Shareholder.

(4) An affidavit of an Officer of the Corporation that the notice has been given by a form of Electronic Transmission shall be conclusive evidence of the facts stated therein.

ARTICLE 76: Notice of Invitation to those Sharing an Address:

Without limiting the manner by which notice otherwise may be effectively given to Shareholders, any notice to Shareholders given by the Corporation shall be effective if given by a single written notice to Shareholders who share an address if consented to by the Shareholders at that address to whom such notice is given. Any such consent shall be revocable by the Shareholder by written notice to the Corporation.

ARTICLE 77: Waiver of Notice:

A Shareholder may waive any required notice before or after the date and time stated in the notice when the shareholder can not attend the meeting. The waiver must be in writing, signed by the Shareholder entitled to the notice and delivered to the Corporation for inclusion in the Minutes or filing with the corporate records. A Shareholder's attendance at a Meeting, whether such attendance be in person or otherwise, waives objection to lack of notice or defective notice of the Meeting, unless the Shareholder at the beginning of the Meeting objects to holding the Meeting or transacting business at the Meeting.

ARTICLE 78: Shareholders Eligible to Receive a Notice:

The By-laws of the Corporation, or the Board of Directors, may set, or provide for , the manner of setting the Record Date in order to determine: the Shareholder s entitled to notice of a Meeting of the Shareholders; to demand a Special Meeting; to vote; or to take any other action.

ARTICLE 79: Conduct of the Meeting:

(1) the Chairman of the Board of Directors, or his designee, shall preside over each Meeting of the Shareholders and shall, unless the Articles of Incorporation, or By-laws, provide otherwise, determine the order of business (consistent with the agenda) and shall have the authority to establish rules for the conduct of the Meeting. 
(2) If a quorum is present, the Chairman, or his designee, shall conduct voting for each matter in accordance with the agenda. When voting is completed the matter shall not be brought under discussion in the event of an objection.

(3) At the Meeting of the Shareholders a List is to be made of all Shareholder s, or their representatives, who are present and their documents and papers and their respective Share ownership. The List shall be signed by the Chairman, or his designee, and, together with other papers and records with respect to the Meeting, and shall be kept by the Corporation in its records.

(4) A copy of the decisions of the Regular/Annual and Special Meetings, together with the Voting and other information relating to such Meetings, shall be prepared and kept by the Corporation.

ARTICLE 80: Shareholders List:

(1) After setting a Record Date for a Meeting, the Corporation shall prepare a written List of the names of all of its Shareholders who are entitled to notice of the Meeting and show the address of and number of Shares held by each Shareholder. The Shareholders' List must be available for inspection by any Shareholder for any purpose related to the Meeting beginning two business days after notice of the Meeting and continuing through the Meeting.

(2) If the Meeting is held solely by means of Remote Communication the List shall also be open to examination by any Shareholder on a reasonably accessible electronic network and the information required to access such List shall be provided with the notice of the Meeting.

(3) Refusal or failure to prepare, or make available, the Shareholders' List does not affect the validity of action taken at the Meeting.

ARTICLE 81: Voting Right of Shareholders:

(1) Except as provided in parts (2) and (3), below, or unless the Articles of Incorporation provide otherwise, each outstanding Share, is entitled to one vote.

(2) The Shares of a Corporation are not entitled to vote if they are owned, directly or indirectly, by a second Corporation (Domestic or Foreign), even if it owns a majority of the voting stock of the Corporation. This provision does not limit the power of a Corporation to vote any Shares, including its own Shares, held by it in a fiduciary capacity.

(3) Redeemable Shares are not entitled to vote after notice of redemption is mailed to the holders and a sum sufficient to redeem the Shares has been deposited with a bank, or other financial institution, under an irrevocable obligation to pay such redemption price.

ARTICLE 82: Participation in Voting:

(1) A Shareholder may vote his Shares in Person or by Proxy.

(2) A Shareholder may appoint a Person to vote, or otherwise act for the Shareholder (a "Proxy"), by signing an appointment form, or by an Electronic Transmission. A Corporation is entitled to accept the Proxy's vote, or other action, as that of the Shareholder making the appointment. An Electronic Transmission must contain, or be accompanied by, information proving that the Shareholder authorized the Transmission. An appointment of a Proxy is effective when a signed appointment form, or an Electronic Transmission, of the appointment is received the Corporation. An appointment may be valid for a period as agreed by the parties.

(3) An appointment of a Proxy is revocable unless the appointment form, or Electronic Transmission, states that it is irrevocable. The appointment requires that the Corporation considers an interest sufficient in law for the shareholder. An appointment made irrevocable hereunder is revoked when the interest with which it is coupled is terminated. Appointments coupled with an interest include the appointment of: 
1. A Creditor of the Corporation who extended its credit under certain terms;

2. An Employee of the Corporation whose employment contract requires the appointment;

3. A Party to a Voting Agreement created under this Law.

(4) The death, or incapacity, of the Shareholder appointing a Proxy does not

affect the right of the Corporation to accept the Proxy's authority until the

Corporation has knowledge of such death or incapacity. A person that

purchases Shares subject to an irrevocable Proxy appointment may revoke the

appointment if he had no knowledge of its existence when he acquired the

Shares and the irrevocable appointment was not stated on the Stock Certificate.

ARTICLE 83: Effectiveness of Documents:

(1) If the name signed on a vote, consent, waiver, or Proxy appointment corresponds to the name of a Shareholder, the Corporation is entitled to give it effect. If the name of the Person taking such actions does not match the Corporation's Shareholder records, the Corporation is entitled to accept a vote, consent, waiver, or Proxy appointment from such Person as if it was act of the Shareholder if:

1. The Shareholder is a legal person and it is signed by an Officer or proper agent of the Entity;

2. The name signed is either:

(i) an administrator, executor, guardian, or conservator representing the Shareholder and, if the Corporation's request, presents evidence of fiduciary authority acceptable to the Corporation with respect to the vote, consent, waiver, or Proxy appointment;

(ii) a receiver, or Trustee in bankruptcy of the Shareholder;

(iii) the Person to whom a power of attorney has been given by the Shareholder;

3. Two or more Persons are the Shareholder as co-tenants, or

fiduciaries, and at least one of the co-owners or fiduciaries signs such document or takes such action.

The Corporation is entitled to reject a vote, consent, waiver, or Proxy

appointment if the Secretary has reasonable doubt about the validity of the

signature thereon, or about the signatory's authority to sign for the

Shareholder. In such case the Corporation is not liable in damages to the

Shareholder for the consequences the acceptance or rejection].

ARTICLE 84: Quorum:

(1) A Quorum for a Meeting of the Shareholders is as prescribed in the Articles of

Incorporation, and if not so prescribed therein as provided for under this Law;

provided that the Articles of Incorporation may not specify a Quorum less

than one-fourth of the number of Shares entitled to vote on any matter or take

any action at the Meeting.

(2) In the absence of such specification in a Corporation's Articles of Incorporation:

1. A majority of Shares entitled to vote, present in Person (or by Proxy),

shall constitute a Quorum at an Regular/Annual Meeting of the Shareholders;

2. In all matters, other than the election of Directors, the affirmative vote

of a majority of the Shares present in Person (or by Proxy) at the

Meeting and otherwise entitled to vote shall constitute the Act of the Shareholders;

3. Directors shall be elected by a plurality of votes of the Shares present in

Person (or by Proxy) at the Meeting and entitled to vote on the election [of Directors];

4. Where Shareholders are divided into specific classes or series, in

consideration of the amount of Shares, if separate votes of each class

or series is required a majority of the outstanding Shares of such class

or series, present in Person (or by Proxy), shall constitute a quorum

entitled to take action with respect to that vote on that matter and the

affirmative vote of the majority of Shares of such class or series present

in Person (or by Proxy) at the Meeting shall be the act of such class or series.

(3) If a quorum is not present, the Meeting of the Shareholders shall be adjourned

until such other time, date, and location shall be set by the Board of Directors 
and announced prior to adjournment. Notice for such subsequent Meeting shall be provided to all Shareholder s as otherwise required in this Law only if the time, date, and location of the next Meeting are not announced prior to adjournment. (4) Once a Share is represented for any purpose at a Meeting it is deemed present for Quorum purposes for the remainder of the Meeting and for any adjournment of the Meeting unless a new Record Date is set for the adjourned Meeting.

ARTICLE 85: Electing Directors:

(1) All elections of Directors shall be by written ballot, unless otherwise provided in the Corporation's Articles of Incorporation or By-laws. If authorized by the Board of Directors such requirement of a written ballot shall be satisfied by a ballot submitted by Electronic Transmission, as provided in this Law.

(2) Unless otherwise provided in the Articles of Incorporation or By-laws, Directors are elected by a plurality of the votes cast.

(3) Shareholders do not have a right to cumulate their votes for Directors unless the Articles of Incorporation specifically provide otherwise. Cumulative Voting means that the Shareholders so designated are entitled to multiply the number of votes they are entitled to cast by the number of Directors for whom they are entitled to vote and then cast the total number of votes for a single candidate, or distribute the product among two or more candidates.

ARTICLE 86: Appointing Inspectors:

(1) Corporation may appoint one or more Persons to act as the inspector(s) and administrator(s) of the voting procedures and the votes at a Meeting of the Shareholders with the duties as determined by the Board of Directors

(2) Inspectors or administrator shall make a written report to the Board of Directors.

ARTICLE 87: Keeping Documents and Records:

(1) Any records maintained by a Corporation in the regular course of its business, including its stock ledger, books of account, and Minute books may be kept on, or by means of, or be in the form of, any information storage device or method, provided that the records are clear, in legible form and usable.

(2) Any Corporation shall make available such documents and records upon the request of any Person entitled to inspect them, in accordance with this law. Such records and documents shall be admissible in evidence and accepted for all purposes, to the same extent as an original paper record of the same information would have been, provided the paper form accurately portrays the record.

(3) Any Shareholder, in Person or by attorney, or other agent, shall, upon written demand stating the purpose thereof, have the right during the usual hours for business, to inspect for any proper purpose the Corporation's stock ledger, a List of its Shareholders, and its other books and records, and to make copies or extracts there from. In this Article, a proper purpose shall mean a purpose reasonably related to such Person's interest as a Shareholder of the Corporation. In every instance where an attorney, or other agent, shall be the Person who seeks the right to inspection, the demand shall be accompanied by a power of attorney, or such other writing, which authorizes the attorney, or other agent, to so act on behalf of the Shareholder. To the extent made available by the Corporation, any Shareholder may receive and/or view such stock ledger, Shareholder List and other books and records on an electronic network, as provided and subject to the restrictions under this Law.

(4) Any Director shall have the right to examine the Corporation's stock ledger, a List of its Shareholders and its other books and records for a purpose reasonably related to the Director's position. The Commercial Court is vested with the jurisdiction to prescribe the inspection by a Director, or Shareholder.

ARTICLE 88: Voting Trusts: 
(1) One or more Shareholders may create a Voting Trust conferring on a Trustee the right to vote, or otherwise act for them, by signing an agreement setting out the provisions of the Trust (which may include anything consistent with its purpose) and transferring their Shares to the Trustee. When a Voting Trust Agreement is signed, the Trustee shall prepare a list of the names and addresses of all owners of beneficial interests in the Trust and deliver copies of the list and Agreement to the Corporation's principal office.

(2) A Voting Trust becomes effective on the date the first Shares subject to the Trust are registered in the Trustee's name. A Voting Trust is valid for not more than 10 years after its Effective Date unless extended for a maximum of another 10 years. An extension shall be delivered to the Corporation's principal office.

ARTICLE 89: Voting Agreements:

Two or more Shareholders may enter into an agreement providing their agreement regarding the manner in which they will vote their Shares.

ARTICLE 90: Concluding Agreements Governing Management of Affairs and Business: (1)The Shareholders may enter into an Agreement governing the exercise of the corporate power, or the management of the business and affairs of the Corporation among the Shareholders, the Directors and the Corporation, or among any of them. (2)An Agreement authorized by paragraph (1) of this Article shall be set forth either in: 1. the Articles of Incorporation , or Bylaws, and approved by all Persons who are Shareholders at the time of the Agreement; or 2. a written Agreement signed by all Shareholders at the time of the Agreement and made known to the Corporation. Shareholder Agreements under this ARTICLE may be amended only by all Persons who are Shareholders at the time of the amendment. Shareholder Agreements are valid for 10 years, unless the Agreement provides otherwise. (3) The existence of a Shareholder Agreement authorized by paragraph (2) shall be valid when noted in the Articles of Incorporation and on the front or back of each Stock Certificate. The failure to note the existence of the Agreement on the certificate or information statement shall not affect the validity of the Shareholder Agreement, or any action taken pursuant to it. Any purchaser of Shares who, at the time of purchase, did not have knowledge of such Agreement shall be entitled to rescission of the purchase. A purchaser shall be deemed to have knowledge of the Agreement if its existence is noted on the Stock Certificate. An action to enforce the right of rescission must be commenced within the earlier of 90 days after discovery of the existence of the Shareholder Agreement or two years after the time of purchase of the Shares. (4) A Shareholder Agreement may limit the powers of the Board of Directors and impose upon the Person or Persons in whom such discretion or powers are vested, liability for acts or omissions imposed by law on Directors to the extent that the discretion, or powers of the Directors are limited by the Shareholder Agreement.

(5) The existence or performance of a Shareholder Agreement mentioned in this Article shall not be a ground for imposing personal liability on any Shareholder for the acts or debts of the Corporation even if the Agreement, or its performance, treats the Corporation as if it were a partnership, provided that the corporate formalities otherwise applicable to the matters governed by the Agreement are failed to observe and implement.

\section{CHAPTER TWELVE DISTRIBUTION OF DIVIDENDS TO SHAREHOLDERS}

ARTICLE 91: Announcement of Capital: The Board of Directors may declare and cause the Corporation to pay Dividends upon 
Shares of the Corporation's Capital Stock, subject to the Corporation's Articles of Incorporation and the limitations in this law.

ARTICLE 92: Distributions of Dividends:

(1) No distribution of Dividends may be made if:

1. The Corporation would not be able to pay its obligations or debts as they became due; or

2. The Corporation's [total] assets would be less than the sum of its total liabilities

3. The Corporation's Reserved Capital would be less than five percent of all shares

(2) Distributions made contrary to paragraph (1) of this Article illegally, the

provisions of ARTICLE 49 hereto will apply to such distributions.

(3) In case the Corporation was to dissolve at the time of distribution, the rights

of persons with preferential rights shall be superior to those of persons

receiving the dividends, unless provided otherwise in Articles of Incorporation.

ARTICLE 93: Reserve Capital

In distribution of profits, at least $5 \%$ of the profits shall be retained as Reserve Capital to compensate for possible losses of the company. No further amount shall be retained as Reserve Capital thus collected after such capital reaches at least $25 \%$ of the company's capital, provided that the charter does not stipulate a higher percentage. Where the price of Shares exceeds their designated value, the additional value may also be retained as Reserve Capital. Where the Reserve Capital reaches the level determined in the Article of Incorporation or law, but subsequently decreases due to any reason, profits shall be retained in accordance with paragraph (1) in the order specified therein until such loss is recovered.

ARTICLE 94: Payment of Dividends:

Dividends may be paid in cash, in property, or in Shares of the Corporation's Capital Stock.

\section{CHAPTER TWELVE MATERIAL CHANGE TO CORPORATE STRUCTURE:}

ARTICLE 95: Amendment of Articles of Incorporation:

(1) The shareholders may amend, increase or omit the provisions of the articles of incorporation.

(2) The Board of Directors must approve and recommend the proposed

amendment to the Shareholders and the Shareholders entitled to vote on the amendment have the right to approve the amendment by a majority of the votes entitled to vote on such proposed action .

(3) Unless the Articles of Incorporation provide otherwise, a Corporation's Board

of Directors may adopt and approve one, or more, of the following

amendments to the Articles of Incorporation without Shareholder approval:

- to delete the names and addresses of: the initial Incorporators;

- to delete the initial principal office;

- to delete the Initial Directors; or initial responsible agent (if current

responsible agent information is on file with the Central Registry).

ARTICLE 96: Increase in Capital of the Corporation:

If the Board of Directors, in its written judgment, determines to increase the authorized capital of the Corporation by increasing the amount of authorized Shares available for issuance, or by creating new classes or series of stock, the Board of Directors shall approve and submit the matter for vote by the Shareholders. Issuance of authorized Shares shall be regulated by ARTICLES 30 and 31 of this Law.

ARTICLE 97: Pre-emptive Rights:

Unless otherwise expressly provided in the Corporation's Articles of Incorporation, or as determined by the Board of Directors, upon any increase in the authorized capital of the Corporation, or issuance of additional Shares by the Corporation, the existing Shareholders 
are not entitled to preemptively purchase, or subscribe for their pro rata Share of any such newly-authorized, or newly-issued Shares of Capital Stock.

\section{CHAPTER THIRTEEN STOCK CERTIFICATES}

ARTICLE 98: Stock Certificates:

(1) The issued and outstanding Shares of Capital Stock of a Corporation may be represented by Stock Certificates, as provided in the Corporation's Articles of Incorporation, or By-laws. At minimum, each Stock Certificate must state the name of the issuing Corporation, the jurisdiction of the organization, the par value, the name of the Person to whom it is issued and the number and class of Shares issued, and shall be signed by two authorized Officers of the Corporation.

(2) Any or all the signatures on the Certificate may be a facsimile. If the Person who signed a Certificate shall have ceased to be an Officer of the Corporation after such Certificate is issued, the Certificate shall remain valid.

ARTICLE 99: Transfer of Shares:

Unless otherwise stated in the Articles of Incorporation, Shares are transferable to others without the consent of the Corporation.

ARTICLE 100: Registration of Shares and Validity thereof:

Shares are transferred to others by endorsement or by another written document. In order for this transfer to be honored it must be registered in the Share Registration Book of the Corporation.

ARTICLE 101: Unpaid Shares:

When the consideration payable for Shares of a Corporation has not been paid in full, and the assets shall be insufficient to satisfy the claims of its Creditors, each holder of, or subscriber for, such Shares shall be bound to pay on each Share held or subscribed for by such holder, or subscriber, the sum necessary to complete the amount of the unpaid balance of the consideration for which such Shares were issued, or are to be issued, by the Corporation.

ARTICLE 102: Unusable Stock Certificates:

(1) A Stock Certificate should become in such bad condition that its further use is impractical, but its contents and distinguishing marks are perfectly legible, its owner is entitled to pay the expenses involved and receive replacement Stock Certificates from the Corporation.

(2) A Corporation shall issue a new Stock Certificate in place of any existing Certificate that has been lost, stolen, or destroyed and the Corporation may compensate for damages in case of any claim concerning the mentioned Certificate. The Corporation may require the owner of such former and replacement Stock Certificate s to indemnify the Corporation against any claim that may be made against the Corporation relating to such Certificate. The Corporation may require the owner of the lost, stolen, or destroyed Stock Certificate to provide the Corporation with a bond sufficient to cover such indemnification obligations.

\section{CHAPTER FOURTEEN DISSOLUTION AND LIQUIDATION OF CORPORATIONS}

ARTICLE 103: Dissolution of Corporations:

The Board of Directors may approve the dissolution of the Corporation by majority of votes and present the proposal (whether conditional or unconditional) to Shareholders meeting for adoption and approval.

ARTICLE 104: Registration of Articles of Dissolution: 
(1) As provided in article 103 , the Corporation may deliver to the Central Registry for filing Articles of dissolution setting forth:

1. The name of the Corporation;

2. The date on which dissolution was authorized by the Board and Shareholders;

3. A statement that the proposal to dissolve was duly approved by the

Shareholders in the manner required by this Law and by the Articles of Incorporation.

(2) The Corporation shall be dissolved upon the date of registering the Articles of dissolution.

(3) "Dissolved Corporation" means a Corporation who's Articles of Dissolution

has become effective and includes a successor entity to which the remaining

assets of the Corporation are transferred subject to its liabilities for purposes of liquidation.

ARTICLE 105: Non-Issuance of Shares and Demanding Dissolution:

(1) A majority of the Incorporators or Initial Directors of a Corporation that has

not issued Shares may dissolve the Corporation by delivering to the Central

Registry for filing Articles of Dissolution that set forth:

1. The name of the Corporation;

2. The date of its Incorporation;

3. A statement that: (i) none of the Corporation's Shares has been issued;

4. That no debt of the Corporation remains unpaid;

5. that a majority of the Incorporators, or Initial Directors, authorized the dissolution .

ARTICLE 106: Revocation of Dissolution:

(1) The general meeting of Shareholders of a Corporation may revoke its dissolution within five days of its Registration and advertisement date.

Revocation of dissolution must be authorized in the same manner as the dissolution was authorized. After the Revocation of dissolution is authorized, the Corporation may revoke the dissolution by delivering to the Central Registry for filing Articles of Revocation of dissolution that set forth:

1. The name of the Corporation;

2. The announcement date for revoking the dissolution;

3. The date that the revocation of dissolution was authorized by the

Corporation's Board of Directors and Shareholders (if Shares issued).

When the revocation of dissolution is effective, the Corporation resumes carrying

on its business as if dissolution had never occurred. Revocation of dissolution is retroactive.

ARTICLE 107: Grounds for Judicial Dissolution:

(1) The Commercial Court of proper jurisdiction may dissolve a Corporation in a proceeding:

1. initiated by the Ministry of Commerce and Industry, if it is established that:

i. The Corporation obtained its Certificate of Incorporation through fraud;

ii. The Corporation has exceeded, or abused, the authority conferred upon it by Law.

2. by one or more Shareholders if it is established that:

i. The Directors are deadlocked in the management of the Corporation's

affairs, the Shareholders are unable to break the deadlock, and

irreparable injury to the Corporation and its assets is being suffered;

ii. the Directors, or those in control, of the Corporation have acted, or are

acting, in a manner that is illegal or fraudulent;

iii. The Shareholders are deadlocked in voting power and have failed, for a

period that includes at least two consecutive Regular/Annual Meetings, to elect Directors.

3. by a creditor if it is established that:

i. The creditor's claim: (i) has been reduced to judgment; and (ii) the

execution on the judgment is unsatisfied; and (iii) the Corporation is insolvent; or

ii. The Corporation has admitted in writing that the creditor's claim is

due and owing and the Corporation is insolvent

iii. When a claim is filed against the Corporation, the Corporation's

voluntary dissolution shall be executed under Court supervision. 
ARTICLE 108: Receivership or Custodianship:

(1) In a Court Proceeding brought to dissolve the Corporation, a Court may appoint one or more receivers to wind up and liquidate, or one or more custodians to manage the business and affairs of the Corporation during such dissolution.

(2) Court appointed receivers must be an individual, or a domestic or foreign Corporation, unaffiliated in any way with the Corporation to be dissolved. The receiver or custodian must receive no benefit from his/her position other than reasonable compensation and reimbursement of expenses from the assets of the Corporation or proceeds of its sale.

(3) The Court shall describe the powers and duties of the receiver or custodian in its appointing order, which may be amended from time to time. Among other powers the receiver may: 1. Dispose of all, or any part of the assets of the Corporation wherever located, at a public or private sale, if authorized by the Court;

2. Sue and defend in his all proper courts.

(4) The custodian may exercise all of the powers of the Corporation through or in place of the Board of Directors to the extent necessary to manage the affairs of the Corporation in the best interests of its Shareholders and creditors.

ARTICLE 109: Decree of Dissolution:

If the Court determines that one or more grounds for judicial dissolution exist, it may enter a decree dissolving the Corporation in accordance with Article 107 of this law and specify the announcement date of the dissolution.

The Court shall deliver a certified copy of the decree of dissolution to the Central Registry. After entering the decree of dissolution, the Court shall direct the winding up and liquidation of the Corporation's business and affairs.

\section{CHAPTER FIFTEEN MISCELLANEOUS PROVISIONS}

ARTICLE 110: Existence of Established Corporations before the Adoption of This Law: The Corporations and limited companies which have been licensed prior to the effective date of this law, based on the provisions of the Commercial Code, or have obtained business licenses from other authorized commercial agencies and have registered the licenses in the offices for commercial documents and trademarks, shall upon the adoption of this law within a period of one year and six months reregister in the Central Registry. In such a case, their legal existence shall continue and they shall be subject to provisions of this law.

ARTICLE 111: Proposing Regulations and Internal Rules For better implementation of this law, the Ministry of Commerce may propose regulations and enact relevant procedures.

ARTICLE 112: Payment of Tax: Corporations and limited labiality companies and their shareholders referred to in this law shall pay tax according to the provisions of applicable law.

ARTICLE 113: Registration of Fraudulent Documents:

A person who intentionally signs a fraudulent document and forwards it for registration to the Central Registry shall be punished according to the provisions of the penal code.

ARTICLE 114: Effective Date:

This law is effective from the date of promulgation and shall be published in the Official Gazette. Upon the effectiveness of this law, all provisions concerning corporations and limited liability companies in the commercial code of Afghanistan, published in Official Gazette \# 89, of 1336 [1957] and the Civil Code, dated, 15, 10, 1355 [1976] and any other legal provisions which are contrary to the provisions of this law shall be null and void. 


\section{LAW ON PRIVATE INVESTMENT \\ (as amended December 6 2005)}

UNOFFICIAL TRANSLATION : This English version of the New Investment Law is prepared by Media Department at AISA, Translating the new Changes seen in New Investment Law amended December, 6, 2005 to the previous English Version. It is not an official version of the Law and should be read and used with regard to this limitation. All reasonable efforts have been made to provide an accurate translation of the official published in Dari and Pashto Languages. Where a person requires more certainty than an unofficial translation of the Official Gazettes can provide, that person is advised to seek proper professional advice based on Official Gazettes.

In the Name of Allah, the most Gracious and Merciful

\section{Chapter One GENERAL PROVISIONS}

\section{Article 1}

This legislation has been adopted to encourage, Support and protect private investments and enterprises under Afghan constitution, article (10), based on market economy regulations and governing its related affairs.

\section{Article 2}

\section{Purpose of Legislation}

The State is committed to maximizing private investment, both domestic and foreign, in the economy. It aims to create a legal regime and administrative structure that will encourage and protect foreign and domestic private Investment in the Afghan economy in order to promote economic development, expand the labor market, increase production and export earnings, promote technology transfer, improve national prosperity and advance the people's standard of living.

\section{Article 3 \\ Definitions}

The following terms are defined to mean:

(a) Capital Assets: shall mean capital assets including, without limitation, equipment and machinery.

(b) Commission: shall have the meaning set forth in Article 6 below.

(c) Foreign Investment: shall mean Investment in the form of freely convertible foreign currency or contributions in kind (in each case transferred from outside Afghanistan) that has been provided by a Foreign Person.

(d) Foreign Investor: shall mean a Foreign Person who has provided Foreign Investment.

(e) Foreign Loan: shall mean a loan, debenture, bond or other form of debt extended to a Registered Enterprise in freely convertible foreign currency by a Foreign Person for a term of not less than one year for the express purpose of enabling the Registered Enterprise to carry on its business in Afghanistan.

(f) Person: shall mean:

1. Native Person: Shall mean:

2. In case of natural person: Any person constituted or organized under applicable law.

3. In case of Legal Native Person: Any person whether privately or governmentally owned or controlled, and includes a corporation, partnership, sole proprietorship, limited liability company, joint venture, association, joint stock company, trust or other entity.

4. Foreign Person: shall mean,

5. In the case of a natural Person: an individual possessing the nationality of a country other than Afghanistan and.

6. In the case of a legal Person: an entity organized under the laws of a country other than Afghanistan (g) Infrastructure: shall mean any facility or service that is used by and/or provided for the benefit of members of the public (or any section of the public) and shall include, without limitation: ----power generation or transmission facilities 
1. Water delivery or treatment facilities.

2. Sewerage or sewage treatment facilities.

3. Waste-treatment or disposal facilities.

4. Airport facilities, facilities in the health sector education facilities

5. Telecommunications facilities, broadcasting facilities

6. Any other service or facility that is designated by the relevant authorities as Infrastructure for the purpose of this Law.

(h) Investment: shall mean currency and contributions in kind, including, without limitation, licenses, leases, machinery, equipment, and industrial or intellectual property rights, provided for the purpose of acquiring shares of stock or other ownership interests in a Registered Enterprise.

(i) Natural Resources: shall mean, reserves, reservoirs or deposits of whatever nature of oil, gas, gold, silver, coal or any other minerals, hydrocarbons or other resources and whether in their natural state or after any kind of treatment, as constituted under applicable law.

(j) Registered Enterprise: shall mean a business entity registered pursuant to the procedures set forth in Articles 12.

(k) ICSID: shall have the meaning set forth in Article 30 below.

(l) UNCITRAL Rules: shall mean the arbitration rules of the United Nations Commission on International Trade Law.

(m) Office: shall mean the Afghan Investment Support Agency, a limited liability company established pursuant to Article 8(c) below.

\section{Article 4}

\section{Investment Generally Permitted}

(a) Except as otherwise set forth in Article 5 below, all Persons, foreign or domestic, may make investments in all sectors of the economy.

(b) Except as otherwise provided by this Law, a Foreign Person may only make an investment in Afghanistan through a Foreign Investment in a Registered Enterprise or through reinvestment from an existing Registered Enterprise.

\section{Article 5}

Areas Where Investment May Be Prohibited, Restricted or Subject to Special Terms

(a) Investment in the following areas is prohibited:

- development of nuclear power;

- establishment of casinos, gambling and similar establishments;

- Production of narcotics and any other intoxicants.

The Commission may from time to time add to or otherwise amend and regulate the list of prohibited sectors.

(b) The commission may from time to time limit the foreign beneficial ownership of business entities operating in certain industries or economic sectors, as specified by the Commission, provided, however, that any such limitation or limitations shall be prospective only and shall not apply to any existing Investment in a Registered Enterprise.

(c) The Commission must discuss with appropriate ministries and institutions, and approve, with the consent of such ministries and institutions, on a case-by-case, investment in certain sectors of the economy (and certain types of Investment). With respect to such investments, the Commission may choose to apply terms that are different from those generally applied to Investments pursuant to this Law, provided, however, that the Ministry of Finance must approve any fiscal incentives that are more generous than those set forth in the Law.

(d) The list of restricted sectors is set forth below:

1. production and sale of weapons and explosives;

2. Non banking finance activities.

3. Insurance activities;

4. investment in Natural Resources (including forestry) and infrastructures (including telecommunications, construction and pipeline set up), but only until special laws, if any, have been promulgated that are applicable to and govern such Investments after which such Investments shall be governed by such special laws. 
(e) The Commission may from time to time add to or otherwise amend and regulate the list of such sectors.

\section{Chapter Two ADMINISTRATION AND MONITORING}

\section{Article 6 \\ Administrative Structure}

(a) The High Commission on Investment (the "Commission") will be the Government's focal point for policy-making on Investment and the highest administrative authority with respect to the implementation of this Law.

(b) To assist it in carrying out its duties, the Commission shall establish the Afghanistan Investment Support Agency (AISA), which is to be named "Office" in this law hereafter, as a limited liability company.

\section{Article 7}

\section{Composition of the Commission}

(a) The Commission shall be composed of:

1. The Minister of Commerce,

2. The Minister of Finance,

3. The Minister of Foreign Affairs,

4. The Minister of Economy,

5. The Minister of Mines and Industries,

6. The Minister of Agriculture, Animal husbandry and Food,

7. The President of Da Afghanistan Bank,

8. The Chief Executive Officer of the Office as a non-voting member, and

9. Two representatives from the private sector as non-voting members, which

representatives will be appointed annually by the Chamber of Commerce of

Afghanistan for one-year terms.

(b) The Minister of Commerce shall serve as Chairman of the Commission. If the Minister of Commerce is unavailable, then he whom the chairman chooses among those members, who deserve the right to vote, shall serve as Chairman in his stead.

(c) If the Commission determines that one of its proposed actions may significantly affect Investment projects or policies in a particular sector which is not represented on the Commission, the relevant Minister(s) shall be invited to participate in the meetings of the Commission that relate to the proposed action.

(d) The Head of State may alter the composition of the Commission.

\section{Article 8 \\ Responsibilities of the Commission}

(a) At its first meeting, the Commission shall adopt, by majority vote, bylaws establishing procedures for conducting its meetings and for making and recording decisions.

(b) The Commission shall monitor the state of Investment in the country and shall propose to any modifications to this Law that it deems advisable.

(c) The Commission shall establish the Office (AISA) for carrying out its administrative duties.

(d) The Commission shall have authority to issue rules for the implementation of this Law and may instruct the Office to draft such rules for review and promulgation by the Commission. These rules may include, if necessary, provisions designed to create additional incentives for Investment in particular economic sectors or regions of Afghanistan whose development is of particular importance. Notwithstanding the foregoing, the Commission may not provide more attractive fiscal incentives than those provided here without the consent of the Ministry of Finance.

(e) The Commission shall initially establish a threshold value (the "Threshold Value"). The Commission shall have the sole authority, after receiving advice from the Office, to recognize Registered Enterprises where Investment is reasonably expected to be greater than or equal to the Threshold Value. The Office shall have the authority to recognize 
Registered Enterprises where Investment is reasonably expected to be less than the Threshold Value, subject to Article 5 above. The Commission may, at its option, set up a procedure to hear appeals from decisions by the Office not to recognize a Registered Enterprise. (f) The Commission shall have the sole authority to recognize Registered Enterprises in all other cases where, according to this Law, decisions to approve must be made by the Commission.

\section{Article 9}

(a) The office shall review and register applications to the extent that it is so instructed by the commission.

(b) The office shall establish a procedure, which shall be subject to the approval of the

commission for the submission review and registration of application for domestic and foreign investment.

(c) The office shall draft appropriate rule and procedures, which shall be submitted to the

commission for approval and published.

(d) The office shall keep records and monitor Registered Enterprises so as to ensure

compliance with the provision of this law.

(e) The office shall promote Afghanistan as an attractive place for investment.

(f) The office shall assist investors in understanding and complying with provisions of the relevant law, rule and procedure.

(g) The office shall facilitate for prospective foreign investors the process of procuring the various permits, approvals and authorizations necessary to implement the activities of a registered enterprise.

(h) The office shall control and monitor provision of this law and any legal documents such as related rules and procedures.

\section{Chapter Three REGISTERED ENTERPRISES}

\section{Article 10 \\ Registered Enterprises}

(a) Pursuant to the terms of this Law, the Commission or the Office, as appropriate, shall recognize business entities as Registered Enterprises upon receipt of an application in accordance with Article 12 below and in accordance with the provisions of Article 13 below. Records of all Investment in such Registered Enterprise shall be kept.

(b) Registered Enterprises may be either:

(i) Business entities organized under Afghan law.

(ii) Business entities organized under the laws of another nation, but registered to do Business in Afghanistan in accordance with the laws of Afghanistan.

(c) Registered Enterprises may have ownership in any of the following forms:

(i) One hundred percent (100\%) ownership by Investors.

(ii) A joint venture between the Government of Afghanistan and other Investors.

\section{Article 11}

Applying for Recognition as a Registered Enterprise

(a) A Person that wishes to register an entity as a Registered Enterprise must submit to the Office an application giving information in substance and form as required by this Law and by rules promulgated by the Commission or by procedures issued by the Office and approved by the Commission

(b) A Person may seek recognition as a Registered Enterprise for a business entity that is already in existence or an entity that will be formed.

(c) Deleted

\section{Article 12}

\section{Recognition of Registered Enterprises}

(a) Within a fixed time period to be specified in rules promulgated by the Commission, the Commission or the Office, as appropriate, shall recognize as a Registered Enterprise any existing entity that meets the requirements for a Registered Enterprise established by this 
Law and has had an application submitted to the Office in accordance with the terms of this Law, unless

(b) the application that was submitted for the entity did not comply with this Law or regulations or rules issued hereunder, or (ii) recognizing the entity as a Registered Enterprise would violate the terms of this Law or regulations or rules issued hereunder or any other law of Afghanistan, or (iii) approval has been denied in accordance with Article 5(c) above or regulations or rules issued thereunder.

If the Commission or Office has denied an application, it shall give an explanation in writing for the denial.

(c) The applicant shall be permitted to re-apply after correcting the situation that gave rise to the denial pursuant to article 12 (b).

(d) If the Commission or Office has not sent the response within the fixed period described above, the entity shall be deemed recognized.

(e) If the Commission or Office has recognized an existing entity, the Office shall immediately register such entity as a Registered Enterprise and provide a certificate to the entity evidencing its status as a Registered Enterprise (the "Certificate of Registration").

(f) If the Commission or Office has recognized an entity that has not yet been formed, the Office shall register such unformed entity as a Registered Enterprise and provide a Certificate of Registration. Thereafter, the entity must be formed within a fixed time period established in rules promulgated by the Commission.

(g) An entity shall retain its status as a Registered Enterprise unless its registration is rescinded pursuant to Article 14 below.

\title{
Article 13
}

Continuing Reporting Requirements for Registered Enterprises

(a) Extraordinary Reporting: A Registered Enterprise must immediately notify the Office if there has been a change in its ownership or capital structure, or if an Investor in the Registered Enterprise contributes additional capital.

(b) Annual Reporting: Registered Enterprises shall annually file an update (the "Annual Update") with the Office. The Annual Update must be submitted to the Office within ninety (90) days of the end of the fiscal year of the Registered Enterprise and shall include an update of the information provided by the Registered Enterprise in its application pursuant to the terms of Article 12 above, along with such other information as the Commission or the Office, as the case may be, deems appropriate.

\section{Article 14}

\section{Loss of Registered Enterprise Status}

(a) The Commission or, if so instructed by the Commission, the Office may review and revoke an entity's recognition as a Registered Enterprise.

(b) Registered status shall only be revoked if (i) the entity is dissolved or otherwise ceases to exist or operate as a viable concern or (ii) the entity violates, in a substantial respect, applicable provisions of this Law.

(c) Except for violations of Article 12(f) above, before an entity's status as a Registered Enterprise is revoked,

(d) Such Registered Enterprise will be informed of the violation and given three (3) months

to remedy the situation and/or bring itself into compliance with this Law.

\section{Chapter Four \\ RIGHTS AND RESPONSIBILITIES OF REGISTERED ENTERPRISES AND OF FOREIGN INVESTORS.}

\author{
Article 15 \\ Application of Afghan Law \\ Unless otherwise specifically provided by this Law or other Afghan laws, all Registered \\ Enterprises, and all investors, whether domestic or foreign, must abide by all applicable laws of \\ Afghanistan.
}




\section{Article 16}

Right to be Free from Discriminatory Governmental Actions

Unless otherwise specifically provided in this Law or other Afghan laws, the provisions of this law and any other Afghan laws shall be applied equally and fairly to all similarly situated Registered Enterprises, whether they have foreign equity ownership or not, and to all similarlysituated Investors.

\section{Article 17}

Tax Concessions for Registered Enterprises

(a) A Registered Enterprise which incurs a net operating loss in any fiscal year may carry this loss forward and apply it as a deduction from its taxable income to the extent permitted in the Income Tax Law.

(b) A Registered Enterprise shall be entitled to an accelerated deduction for depreciation on Capital Assets to the extent permitted in the Income Tax Law.

\section{Article 18}

Import-Export Duty and Tax Concessions for Registered Enterprises

(a) A Registered Enterprise shall be exempted from export duties and export taxes on products that it manufactures or assembles in Afghanistan to the extent permitted in the Customs Law. An export license shall be required for such exports but such license shall be granted automatically upon submission of such documentation as is required by law.

(b) Deleted

\section{Article 19}

\section{Access to Banking}

(a) A Registered Enterprise shall have the right to use banking facilities in Afghanistan: including the right to open accounts in foreign currency and to use these banks to receive loans and credit in foreign currency from outside Afghanistan to advance its legitimate business.

(b) A Registered Enterprise shall have the right to maintain bank accounts in foreign currency outside of Afghanistan for the purpose of purchasing equipment and machinery, raw materials, spare parts, feedstock and for services used by the Registered Enterprise in conducting its operations, and for payment of salaries and benefits to expatriate employees, and for all other purposes of the Registered Enterprise that are not contrary to Afghan laws.

\section{Article 20}

\section{Labor and Employment}

(a) Notwithstanding any provision to the contrary in Afghan laws, a Registered Enterprise shall have the right, directly or indirectly, to employ foreign managerial and expert personnel of any nationality

(a) A Registered Enterprise shall have the right to enter into service contracts with foreign Persons in order to conduct its business activities. The Registered Enterprise shall have the right to obtain work permits for such managerial and expert personnel, PROVIDED THAT employees of Registered Enterprises, regardless of nationality, shall be subject to and shall comply with the laws applicable in Afghanistan while present in Afghanistan.

(b) Foreign Investors and Registered Enterprises in which Foreign Investors have equity ownership are encouraged to hire Afghan personnel whenever possible in order to further their technical development.

\section{Article 21}

\section{Land Use by Registered Enterprises}

Notwithstanding any law or regulation in Afghanistan to the contrary, a Registered Enterprise shall not be barred by law from leasing real property for terms of up to fifty (50) years. 


\section{Chapter Five \\ TRANSFER OF CAPITAL AND PROFITS ASSOCIATED WITH FOREIGN INVESTMENT}

\section{Article 22}

Transfer of Foreign Investment Capital

(a) Notwithstanding any currency restrictions in Afghanistan to the contrary, a Foreign Investor shall be permitted to freely transfer out of Afghanistan without unreasonable delay distributions received from a Registered Enterprise, to the extent that such distribution is treated as a distribution of capital under the Income Tax Law, in whatever foreign currency the Foreign Investor chooses, at the prevailing exchange rate for that currency, in an aggregate amount equal to the amount of such Foreign Investor's registered Foreign Investment.

(b) The transfer of these funds may take place in one or more transactions as accorded in article 22 (a). PROVIDED.

(c) Except as otherwise provided by law, each time a Foreign Investor transfers out of Afghanistan funds pursuant to Article 22(a) above, it must notify the Central Bank (or such other entity as the Law may designate to keep records of Foreign Investment in Afghanistan) whereupon, the Central Bank or other entity, as the case may be, shall reduce the amount of such Foreign Investor's registered Foreign Investment by the amount that has been transferred.

\section{Article 23}

Transfer of Profits Associated with Foreign Investment

A Foreign Investor shall be permitted to freely transfer outside of Afghanistan without unreasonable delay dividends, or distributions treated as dividends under the Income Tax Law, received from a Registered Enterprise in whatever foreign currency the Foreign Investor chooses, at the prevailing exchange rate for that currency.

\section{Article 24}

Transfer of Principal and Proceeds on Foreign Loans

A Registered Enterprise shall be permitted freely to transfer out of Afghanistan funds for payment of principal, interest and fees relating to a Foreign Loan to such Registered Enterprise in the currency of the Foreign Loan at the prevailing exchange rate, provided that such Foreign Loan is entered into in accordance with all applicable Afghan Laws.

\section{Chapter Six SALE OF APPROVED ENTITIES; TRANSFER OF PROCEEDS}

\section{Article 25 \\ Sale of Approved Entities}

(a) An investor in a Registered Enterprise, after settling his legal and financial obligations, shall have the right to sell or transfer all or a part of its ownership interest in a Registered Enterprise to domestic or foreign Persons or the Afghan Government, in its discretion, without approval of the office, or relevant agencies, PROVIDED THAT the purchaser's Investment in the Registered Enterprise shall not violate any applicable Afghan law.

(b) The Commission shall have the right to void any sale made in violation of this provision.

(c) The Office shall be notified of any sale or transfer of an ownership interest in a Registered Enterprise and the purchaser shall be recorded as a Foreign Investor or domestic investor as the case may be.

\section{Article 26 \\ Transfer of Proceeds from the Sale of Approved Enterprises}

After a sale or transfer of an interest in a Registered Enterprise, a Foreign Investor shall, subject to payment of any taxes applicable to such sale or transfer in Afghanistan, be permitted freely to transfer out of Afghanistan immediately, in the currency of the Investment at the prevailing exchange rate, the proceeds of any such sale. 


\title{
Chapter Seven \\ EXPROPRIATION
}

\begin{abstract}
Article 27
Expropriation

The state is authorized to expropriate an Investment or assets of a Registered Enterprise for an overriding public purpose. The decision to expropriate shall be based on a law permitting such expropriation and shall be made on a non-discriminatory basis.
\end{abstract}

\section{Article 28}

Compensation of Loss

(a) The State shall provide prompt, adequate and effective compensation in conformity with principles of international law, equivalent to the fair market value of the expropriated Investment or assets immediately before the expropriatory action was taken. Such compensation shall include interest at the one-year LIBOR rate for the period between the date of the expropriation or nationalization and the date of complete payment of the compensation. In the case of an Investment made in a foreign currency, the compensation shall be made in the currency in which the Investment was made at the prevailing rate of exchange.

\section{Article 29}

Transfer of Capital, Compensation and Right to Dispute

(a) A Foreign Investor or a Registered Enterprise of which over [(25\%)] of the ownership interest is held by Foreign Investors may freely transfer any payment from the Government as compensation for expropriation or nationalization out of Afghanistan without the payment of taxes to the extent that such exemption is permitted in the Income Tax Law.

(b) Except as otherwise provided by Law, if the State expropriates the assets of a Registered Enterprise of which over [(25\%)] of the ownership interest is held by

Foreign Investors, such Foreign Investor or Registered Enterprise, as the case may be, shall have the right immediately to dispute the expropriation or the adequacy or fairness of the compensation therefor, pursuant to the provisions of Article 28 above.

\section{Chapter Eight DISPUTE RESOLUTION}

\section{Article 30 \\ Dispute Resolution}

(a) Any raised dispute shall be resolved in reference to provisions of this legislation.

(b) Except as otherwise provided below, an Investor or a Registered Enterprise may, in any contract or other agreement, specify:

I. any arbitration or other dispute resolution procedure,

II. that the place of such arbitration may be outside of Afghanistan, and

III. that the law of a jurisdiction other than Afghanistan may apply to the resolution of such dispute If such contract or other agreement so provides,

(c) Any award resulting from such arbitration or other dispute resolution procedure shall be final, and shall be enforceable in accordance with the Arbitration Law upon application of any party to such arbitration or procedure.

(d) Except as otherwise provided in subsection (e) below, If a dispute arises pursuant to a contract or other agreement entered into between an Investor or a Registered Enterprise on the one hand and the State (or any constituent subdivision, agency or instrumentality thereof) on the other, with regard to an Investment, or if an Investor or Registered Enterprise has a claim under Article 28 (b) of this Law, the dispute shall be resolved according to applicable Afghan law.

(e) If a dispute arises pursuant to a contract or other agreement entered into between a 
Foreign Investor or a Registered Enterprise with foreign equity ownership and the State or any constituent subdivision, agency or instrumentality thereof in regard to a Foreign Investment, or if a Foreign Investor or Registered Enterprise has a claim under Chapter 7 of this Law, the parties shall endeavor to settle such dispute amicably by mutual discussions. Failing such amicable settlement, and unless the parties to such dispute otherwise agree, the parties shall submit such dispute either

(i) to the International Centre for Settlement of Investment Disputes ("ICSID") for settlement by arbitration pursuant to the Convention on the Settlement of Investment Disputes between States and Nationals of Other States of March 18, 1965 , as such may have been or may be amended from time to time (the "Convention") (ii) if ICSID rules preclude the Foreign Investor from arbitrating before ICSID or if the Foreign Investor otherwise prefers, to arbitration in accordance with UNCITRAL Rules. The Government, by operation of this article subsection (a), consents to the submission of any such dispute to ICSID for settlement by arbitration in accordance with Article 25(1) of the Convention.

(f) A Registered Enterprise incorporated under Afghan Laws or otherwise registered to do business in Afghanistan of which over twenty five percent (25\%) of the ownership interest is owned by a Foreign Investor shall be treated as a national of a state other than Afghanistan. For the purpose of Article 25(3) of the Convention, if one of the disputing parties is a constituent subdivision, agency or instrumentality of the State, the Government, by operation of this Article 29(c), gives its consent to the submission of such dispute to ICSID for settlement by arbitration and no further consent of the State is required for the submission of such dispute to ICSID.

\section{Chapter Nine MISCELLANEOUS}

Article 31

Preference

If anything provided in this legislation is in conflict with the provisions of any other law in relation to investment in Afghanistan, those specified in this law shall be preferred.

\section{Article 32}

\section{Transitional Provisions}

(a) An entity which approved prior to execution of this law, as specifically provided in the income-tax law article 115, can avail itself of the concession accorded in "The private domestic and foreign investment legislation that was published in official Gazette number[803] Dated 1381.

(b) Any Investor or Approved Enterprise, which is registered as an Approved Enterprise under the domestic and foreign private investment law that was published in official Gazette number [803] Dated 1381, require to re-registered with the office within six (6) month from the date of execution of this law or such longer period as may be established in rules issued by the commission.

(c) Any Approved Enterprise that is registered in accordance with article 32(b) is considered registered and Approved Enterprise and will be fully subject to this law.

(d) Any Investor or Approved Enterprise, fails to re-register in accordance with articles 32(b) above, shall be ineligible to avail themselves of the rights and privileges accorded under this law.

(g) [Deleted]

\section{Article 33 \\ Execution and abrogation}

Upon its execution by the Head of State, this legislation will be published in the Official Gazette and upon execution of this Law, private foreign and domestic investment legislation that was published in the Official Gazette number [803] will become null and void. 


\section{INCOME TAX LAW}

An unofficial translation of the Income Tax Law 2005 as published in Official Gazette number 867 dated 26 November 2005

This translation has been prepared by the Department of Revenue, Ministry of Finance. It is not an official version of the law and should be read and used with regard to this limitation. All reasonable effort has been made to provide an accurate translation of the law as published in the Official Gazette. Where a person requires more certainty than an unofficial translation of the law can provide, that person is advised to seek professional advice based on the law in the languages of Dari and Pashtu as published in the Official Gazette.

\section{Contents}

CHAPTER I - General Provisions

Article 1 Authority

Article 2 Tax implementation

Article 3 Tax (fiscal) Year

Article 4 Tax calculation

Article 5 Tax on residents

Article 6 Non-residents tax exemptions

Article 7 Non-residents and allowable deductions

Article 8 Tax on business activities

Article 9 Tax on foreign governments and international organizations

Article 10 Tax Exempt Organizations

Article 11 Tax Exemptions of government

CHAPTER II - Determination of Taxable Income

Article 12 Definitions

Article 13 Receipts subject to tax

Article 14 Non-taxable income

Article 15 Food and fuel tax exemption

Article 16 Taxes on rent and lease of immovable properties

Article 17 Liability to withholding tax from salary or wages

Article 18 Deductible expenses

Article 19 Non-deductible expenses

Article 20 Income from domestic sources

CHAPTER III - Gain or Loss from the Sale, Exchange or Transfer of Assets

Article 21 Gains subject to income tax

Article 22 Taxable gain of fiscal year

Article 23 Tax on transfer of property

Article 24 Deduction of expenses from taxable income

Article 25 Tax determination based on market value

Article 26 Form of transfer no effect on tax liability

Article 27 Deduction of loss incurred from taxable income

Article 28 Non-deduction of additional loss from taxable income

Article 29 Computing tax on capital gains

Article 30 Tax on sale of movable or immovable Property

CHAPTER IV - Partnerships

Article 31 Definitions

Article 32 Limited liability company and special partnership

Article 33 General partnerships

Article 34 Determination of net income

Article 35 Distribution of receipts

CHAPTER V - Rules for Accounting

Article 36 Maintenance and preservation of records

Article 37 Accrual method of accounting 
Article 38 Cash method of accounting

Article 39 Form and content of records

Article 40 Inventory at the close of year

Article 41 Tax determination of two or more businesses

CHAPTER VI - Special Provisions for Corporations and Limited Liability Companies

Article 42 Deduction of operating loss

Article 43 Distribution of assets to shareholders

Article 44 Distribution of assets at the time of liquidation of company

Article 45 Distribution of money or other assets

Article 46 Withholding tax

Article 47 Deduction of depreciation and losses

CHAPTER VII - Taxation of Insurance Companies

Article 48 Provisions for applicable insurance companies

Article 49 Taxable income of insurance companies

Article 50 Exemption of certain policy holders

Article 51 Non-deductible expenses of insurance companies

Article 52 Deductible expenses of insurance companies

Article 53 Determination of taxable income of foreign insurance companies

CHAPTER VIII - Taxation of Banks, Loan And Investment Corporations

Article 54 Gains subject to tax

Article 55 Deduction of necessary expenses

Article 56 Additions to reserves

Article 57 Increase or decrease in value of securities

CHAPTER IX - Withholding Taxes on Income Sources

Article 58 Withholding and payment of tax

Article 59 Rent withholding tax on buildings and houses

Article 60 Remittance of tax payments

Article 61 Preparation of statements

Article 62 Time for submission of statements

Article 63 Submission of return

CHAPTER X - Business Receipts Tax

Article 64 Business receipts tax

Article 65 Rates of business receipts tax

Article 66 No effect of profit or loss on business receipts tax

Article 67 Deductible amount

CHAPTER XI - Fixed Taxes

Article 68 Fixed tax on commercial activities

Article 69 Payment of fixed tax

Article 70 Fixed tax on imports

Article 71 Fixed tax on exports

Article 72 Fixed tax on transport

Article 73 Fixed tax of government contractors

Article 74 Fixed tax of exhibitions

Article 75 Fixed tax of grain and processing mills, cane and seed oil machinery

Article 76 Fixed tax of place of business

Article 77 Determination of fixed tax on place of business

Article 78 Fixed tax of physicians

Article 79 Amendments to exemptions

Article 80 Fixed tax on persons without fixed place of business

Article 81 Fixed tax of brokers and commission agents

CHAPTER XII - Taxation Rules for Qualifying Extractive Industry Taxpayers

Article 82 Definitions

Article 83 Precedence of Chapter XII

Article 84 QEIT treated as separate taxpayer for each Authorization, License or Contract

Article 85 Business Receipts Tax

Article 86 Depreciation deductions 
Article 87 Cost of constructing roads

Article 88 Pre-production costs

Article 89 Deduction for contributions to a fund for environmental and social obligations

Article 90 Loss carry-forward and stability agreements

CHAPTER XIII - Assessments, Returns, Objections and Payment of Tax

Article 91 Tax Identification Number

Article 92 Assessments and amended assessments

Article 93 Submitting returns and payment of tax

Article 94 Objections and appeals

Article 95 Refunds

Article 96 Information collection

CHAPTER XIV - Enforcement Provisions

Article 97 Collection of unpaid tax from third parties

Article 98 Liability of directors, shareholders and other persons

Article 99 Persons not allowed to leave Afghanistan

Article 100 Business closure

Article 101 Restriction on disposal of property by a taxpayer

CHAPTER XV - Anti-Avoidance

Article 102 Transactions between connected persons

Article 103 Anti-avoidance

CHAPTER XVI - Additional Tax And Penalties

Article 104 Offenses and penalties

Article 105 Additional income tax where tax is paid late

Article 106 Additional income tax where records were not maintained

Article 107 Additional income tax where a tax return was not filed

Article 108 Additional income tax where tax was not withheld

Article 109 Additional income tax where tax was not paid

Article 110 Additional income tax related to Tax Identification Numbers

Article 111 Offenses committed by taxation officers

Article 112 Authority for collection of additional tax

CHAPTER XVII - Final Articles

Article 113 Provision of forms and rulings

Article 114 Non issuance of licenses

Article 115 Requirements for entitlement to exemption

Article 116 Primacy of Income Tax Law

Article 117 Enforcement date

DECREE OF THE PRESIDENT and transitional provisions

\section{CHAPTER I \\ GENERAL PROVISIONS}

Article 1 Authority

This Law is imposed under the authority of Article 42 of the

Constitution of Afghanistan for the purpose of tax determination and tax

payment.

Article 2 Tax implementation

(1) A tax is imposed on the income from Afghan

sources of all natural persons, corporations, limited liability companies, and

other legal entities whether in Afghanistan or abroad, and on the foreign

income of residents of Afghanistan in accordance with the provisions of this

Law.

(2) A natural or legal person is considered a resident of Afghanistan if:

1. The person has his or her principal home in Afghanistan at

any time during the fiscal year; or

2. The person is present in Afghanistan for a period or periods 
amounting to one hundred eighty-three days in the fiscal year; or

3. The person is an employee or official of the Government of

Afghanistan assigned abroad at any time during the fiscal year.

4. Any other entity is resident in Afghanistan for a fiscal year if it

was established in Afghanistan or has the centre of its

administrative management in Afghanistan at any time

during the fiscal year.

Article 3 Tax (fiscal) Year

(1) The income tax is imposed for each taxable year

on the taxable income of each person, corporation, limited liability company,

or other entity. The taxable year is the solar year which starts from the first

day of Hamal (21 March) and ends on the last day of Hoot (20 March).

(2) A legal person wishing to use a different taxable year than that mentioned

in paragraph (1) of this Article shall apply, in writing, to the Ministry of Finance

setting out the reasons for the change of that person's taxable year to another

twelve-month period. The Ministry of Finance may grant such application but

only where the application is justifiable.

(3) Permission to use a different taxable year under paragraph (2) of this

Article takes effect from the date specified by the Ministry of Finance by notice in writing.

(4) The Ministry of Finance is authorized to withdraw the approval prescribed

in paragraph (3) of this Article when required.

Article 4 Tax calculation

(1) The income tax of legal persons is 20 percent of

its taxable income in the fiscal year.

(2) Income in foreign money shall be converted to afghanis for purposes of

taxation. The rate of conversion shall be the average of free rates used by

Da Afghanistan Bank to purchase such foreign money at the end of each month.

(3) The income tax of a natural person is the amount calculated in

accordance with the following schedule:

TAXABLE INCOME INCOME TAX

From

1 afghani up to afs 12,500 per month

From afs 12,501 up to afs 100,000 per month ............. 10\%

From afs1 00,001 per month in addition to afs 8,750 . $20 \%$

Article 5 Tax on residents

(1) Tax on income of resident natural persons

in Afghanistan shall be calculated as follows:

1. In accordance with taxable income including income from

sources outside Afghanistan.

2. Any income tax paid to the government of a foreign country by

a resident natural person of Afghanistan may be taken as

credit only against that part of his annual income tax

attributable to his foreign income.

3. If the income of a resident natural person is derived from more

than one foreign country, the income tax credit shall be applied

in proportion to the income from each country as provided in

the Income Tax Manual established by the Ministry of Finance.

(2) All legal persons are subject to income tax on all taxable income from all

sources within Afghanistan and outside Afghanistan according to the

provisions paragraph (1) of this Article. 
Article 6 Non-residents tax exemptions

Non-resident persons are exempt

from income tax provided that the foreign country grants a similar

exemption to residents of Afghanistan.

Article 7 Non-residents and allowable deductions

(1) Individuals, companies and

other non-resident persons not engaged in trade or business in Afghanistan

are subject to income tax on the amount received from sources within

Afghanistan as interest, dividends, rents, royalties, and gain or profit of any

kind according to the provisions of this Law.

(2) Deductions allowed under this Law are only allowed in respect of income other than interest, dividends, rents and royalties to those nonresident

legal persons which file a true and accurate return including all

information required by this Law and the Income Tax Manual established

by the Ministry of Finance.

Article 8 Tax on business activities

(1) Non-resident natural persons, companies

and other organizations engaged in economic, service or business activities

in Afghanistan are subject to income tax on all taxable income from sources within Afghanistan.

(2) Deductions are allowable only if and to the extent that they are

connected with income from sources within Afghanistan.

(3) Income derived from the operation of aircraft and by its staff under the

flag of a foreign country are exempt from taxation provided that the foreign

country grants a similar exemption to aircraft and its staff under the flag of Afghanistan.

(4) A correct apportionment of expenses with respect to sources of income

within Afghanistan shall be determined as provided by this Law and the

Income Tax Manual.

(5) Where a non-resident person carries on business in Afghanistan through

a branch in Afghanistan, the taxable income of the branch is determined as if

the branch were a separate legal person and calculated as follows:

1. payments or amounts incurred to another part of the nonresident

person are deemed to be dividends under paragraph

(3) of Article 13 of this Law,

2. no deduction is allowed for payments or amounts incurred to

another part of the non-resident person according to paragraph

(2) of Article 18 of this Law, and

3. expenses incurred by the branch or another part of the nonresident

person that related directly to the earning of gross

income by the branch are treated as expenses incurred by the

branch as a separate legal person.

Article 9 Tax on foreign governments and international organizations

The taxability of income in Afghanistan of foreign governments, international organizations, and of their employees not residents of Afghanistan shall be determined by the provisions of existing agreements, treaties and protocols with the government of Afghanistan.

Article 10 Tax Exempt Organizations

(1) Contributions received and income from

the necessary operations of organizations that meet the following

conditions are exempt from taxation:

1. The organization must be established under the laws of Afghanistan.

2. The organization must be organized and operated exclusively for 
educational, cultural, literary, scientific, or charitable purposes.

3. Contributors, shareholders, members or employees either during

the operation or upon dissolution of the organization mentioned

in sub-paragraphs 1 and 2 of this paragraph must not benefit from the organization.

(2) The process of exemption from income tax for organizations prescribed

in paragraph (1) of this Article shall be provided in the Income Tax Manual.

Article 11 Tax exemptions of government The income of agencies and

departments of the State and of municipalities is exempt from taxation.

Government enterprises are excluded from the provisions of this Article.

\section{CHAPTER II \\ DETERMINATION OF TAXABLE INCOME}

Article 12 Definitions

Taxable Income is the total of all receipts of an individual, corporation, limited liability company, or other legal person less those exemptions and deductions authorized in this Law.

Exemptions are deductions from income of the taxpayer given in accordance with the provisions of this Law.

Deductions are expenses of production, collection, and preservation of

income, which are allowed, by provisions of this Chapter, to be deducted from receipts.

Expenditures and costs not specifically defined as exemptions or

deductions are not deductible.

Net Operating Loss is the amount that exceeds income after allowance of

deductions prescribed in this Law.

Article 13 Receipts subject to tax

(1) The following receipts are subject to income tax:

1. salaries, wages, fees and commissions,

2. all receipts derived from business and industry,

3. receipts from sale of movable and immovable property,

4. interest, dividends, rents, royalties, awards, prizes, winning,

bakhshishis (gratuities, bonus payments),

5. distributive shares of partnership gross income,

6 . any other return from labor, capital, or economic activity,

7. income from other circumstances provided in this Law.

8. any other income which has not been provided in this Law.

(2) Dividends mean any distribution by a company in money or in property and

any benefit provided to shareholders in their capacity as shareholders including:

1. any tangible or intangible assets;

2. shares in the company;

3. discounts on any purchases from the company;

4. loans to shareholders

5. the use of any company property.

(3) Where a branch in Afghanistan of a non-resident person (as defined in Article 8 of this Law) pays or incurs an amount to the non-resident person or any person connected to the non-resident person, that amount will be treated as a dividend.

Article 14 Non-taxable income

The following receipts are not subject to income tax

and not included in returns of natural and legal persons:

1. grants, gifts, and awards of the State;

2. grants, gifts, and awards of foreign governments, international

organizations, or nonprofit organizations for contributions to science, art,

literature, social progress, and international understanding;

3. all scholarships, fellowships, and grants for professional and technical training; 
4. health, accident, and unemployment insurance benefits;

5. life insurance paid on death;

6. compensation or damages for personal injuries or sickness or restitution of reputation;

7. proceeds of borrowing;

8. proceeds of issues of stocks and bonds by companies;

9. acquisition of property in connection with mergers of domestic

corporations and other legal entities;

10 acquisition of movable or immovable property through expropriation of

property of debtors by creditors;

11. payments on principal received from debtors;

12. interest on deposits of individuals from State banks;

13. interest on bonds issued by the State and by municipalities; and

14. any other receipts according to the provisions of this Law.

Article 15 Food and fuel tax exemption

Income represented by the value of

food, fuel, and goods consumed or used by the producer of the same or by

members of his household is excluded from income tax.

Article 16 Taxes on rent and lease of immovable properties

Rent received in money or otherwise from renting and leasing immovable property used for commercial, industrial and other economic purposes is subject to income

tax. Taxation of agricultural lands, gardens, and livestock together with their income are taxed by separate laws.

Article 17 Liability to withholding tax from salary or wages

(1) Ministries, agencies

and other government organizations, enterprises, companies and charitable

institutions are required to withhold taxes from the salary or wages of its

employees when they are being paid and transfer the withheld amount to

the government account.

(2) Pensions of government employees are exempt from income tax.

Article 18 Deductible expenses

(1) Deduction of all ordinary and necessary

expenses of the production, collection, and preservation of income of

natural and legal persons is allowed and deductible as follows, provided

that these expenses have been incurred during the taxable year, or one of

three previous years, in accordance with the provisions of this Law.

1. Any expense related to the cost of production or trade and

business, such as insurance and freight expenses, etc.;

2. The cost of supplies, materials, fuel, electricity, water, and

ordinary and necessary expenses used in the production of

income, or in a trade or business;

3. Wages, salaries, commissions, and fees paid for services

rendered by employees in trade or business;

4. Interest paid on business loans;

5. Rent paid on property necessary to and used in trade or business;

6. Cost of repairs and maintenance of properties and

equipment necessary to and used for purposes of the business or trade;

7. Depreciation of moveable and immovable property (except

agricultural land) used in a trade or business or held by the

producer for the production of income In accordance with the

Income Tax Manual. The total of deductions for depreciation

of any item of property over a period of years shall not

exceed its cost to the taxpayer; 
8. Any tax or charge that is necessary expense of doing business, holding property for income, or of producing income, if paid or accrued during the taxable year. Taxes imposed by this Law and taxes not qualifying as necessary business expense are not deductible, except as otherwise provided by this Law;

9. Damages to movable or immovable property caused by fire, earthquake, and by casualty or disaster of any kind, over a three year period, to the extent that the cost is determined and substantiated by records and the loss was not recovered by insurance;

10. Losses in business or trade from bad debts according to the Income Tax Manual;

11. Dividends paid in money by a legal entity organized under the laws of Afghanistan; and

12. Other expenses of doing business and of holding movable or

immovable property for the production of income under

relevant legislative documents.

(2) No deductions are allowed for the following expenses:

1. Expenses incurred to provide entertainment or advertising that are not connected to economical or commercial activities; 2. Dividends, interests, royalties, rents, commissions, wages, salaries and similar expenses from which legal persons are required under provisions of this Law to withhold tax but have failed to do so; and 3. In the case of a branch in Afghanistan of a non-resident person, any expenses paid or incurred to the non-resident person or any person connected to the non-resident person.

Article 19 Non-deductible expenses

(1) Personal expenses including the following expenses are not deductible:

1. payments made to persons for his or his family's benefit and enjoyment;

2. expenses and costs of maintenance, repair, construction,

improvement, furnishing, and other expenses of the

taxpayer's or his family's house or residence or any property

devoted to his own personal or family's use;

3 . interest on personal loans;

4. costs of commuting to and from work and cost of travel for

personal purposes;

5. cost of life, accident, health, and liability insurance for the

protection of the taxpayer and his family; and

6. cost of insurance of any kind for the protection of property

used for personal purposes.

(2) The following expenses are not deductible:

1 . The cost of acquiring land, buildings, durable items such as

machinery, equipment, fixtures, and furniture, or costs of

additions or improvements to the same. Depreciation

expense allowable under sub-paragraph 1 (7) of Article 18

and the provisions of Chapter 3 of this Law are excepted from this paragraph;

2. Additions to reserves for contingencies, bad debts, and other similar purposes; and

3. Taxes paid to foreign countries by non-resident persons on

income from sources within Afghanistan, except as provided

by an existing treaty.

Article 20 Income from domestic sources

(1) Income from sources within

Afghanistan is as follows:

1. Interest from loans, deposits, investments, etc.;

2. Dividends received from resident companies doing business in Afghanistan;

3. Salaries, wages, self-employment income, etc. for services performed; 
4. Rentals and royalties from any property (movable and immovable);

5. Gain from sale of immovable and movable property;

6. Commissions on sales of any kind including insurance;

7. Income from commercial activities within Afghanistan;

8. Gains from the sale or transfer of any movable property used

in commercial or employment activities;

9. Royalties, a management fee, an annuity, or a commission paid by a resident of Afghanistan;

10. Income from exploitation of any interest in a right to explore

for, or exploit, any mineral, petroleum, or any other resources; and

11. Income from other sources in Afghanistan which is subject to

tax according to the provisions of this Law.

(2) For the purposes of this Law, apart from Articles 29 and 30, the term

"immovable property" in subparagraph (5) of paragraph (1) of this Article

includes any benefit in a company or other entity where the value of the

assets of the company or entity results principally from ownership either

directly or indirectly through other persons of -

1 immovable property in Afghanistan; or

2 benefits in immovable property in Afghanistan, including

hydrocarbon contracts and mining licenses and mining

authorizations as defined in Chapter XII.

(3) For the purposes of this Law, apart from Articles 29 and 30, exploitation of an interest described in subparagraph (10) of paragraph (1) of this Article

includes any sale of or other dealing with an interest.

\section{CHAPTER III \\ GAIN OR LOSS FROM THE SALE, EXCHANGE, OR TRANSFER OF ASSETS}

Article 21 Gains subject to income tax

The gain from the sale or exchange of a capital asset or investment in a trade or business is subject to income tax.

Article 22 Taxable gain of fiscal year

The gain from the sale or exchange of

any asset of a corporation or limited liability company is taxable income in

the taxable year the asset was transferred.

Article 23 Tax on transfer of property

(1) Gain from the sale, exchange, or

transfer of the following assets is taxable income:

1. a trade or business, including goodwill;

2. a factory including equipment, machinery, buildings and land, or any part of such assets;

3 equipment used in the business of transporting persons and property; and

4. shares of stock in corporations or limited liability companies.

(2) Gain from the sale or transfer of movable or immovable property

acquired by inheritance is excluded from the provisions of paragraph (1) of this Article.

Article 24 Deduction of expenses from taxable income

Proceeds from sale, exchange, and transfer of assets, (except by inheritance), shall be reported

in full. The following deductions are allowed in determination of taxable gain:

1. Cost to the taxpayer of the asset and investment sold, less the total

amount allowable for its depreciation since it was acquired.

2. Expenses of sale including sales commissions, advertising

expenses, legal expenses, transaction and document taxes, and

other expenses of selling and transferring the asset. 
Article 25 Tax determination based on market value

The market value of the movable or immovable asset at the time it was transferred or exchanged (except inheritance), shall be the basis for computing the gain.

Article 26 Form of transfer no effect on tax liability

The form or nature of the transfer of movable or immovable assets shall not affect taxability of the gain from the transfer, except by inheritance, which is not taxable.

Article 27

Deduction of loss incurred from taxable income Losses from the sale or exchange of capital assets used in trade or business are deductible from the taxable income of the taxpayer in the taxable year in which the sale or exchange took place, provided that a gain from such sale or exchange would have been taxable.

Article 28

Non-deduction of additional loss from taxable income Loss from sale or exchange of shares of stock is not deductible except from the gain from sale or exchange of shares of stock in the same year. For any such gain, if in excess of loss from such transactions, the excess is taxable, but if any such loss is in excess of gain, the excess loss is not deductible.

Article 29

Computing tax on capital gains The method of determining and computing tax on capital gains is as follows:

(1) Gain, taxable under Article 23 of this Law, from the sale or transfer of an asset owned by a person eighteen months or more is subject to the provisions of this Article if one or more of the following criteria and conditions is met:

- the transfer (except by inheritance) of property was not a sale;

- the asset transferred was a capital asset;

- the asset was transferred in the sale or liquidation of a business.

(2) The income tax of any person in any taxable year where assets were transferred under any of the circumstances described in paragraph 1

of this Article will be the product of the person's taxable income from all sources multiplied by the special rate imposed by paragraph (3) of this Article.

(3) The special rate imposed by this Article shall be determined as follows:

- the gain from transfer of any asset (except by inheritance) is

divided by the number of years it was owned;

- the average annual gain or gains so determined are added to all other taxable income and income tax is computed according to the rate schedule in Article (4) of this Law.

- the tax so obtained, divided by the amount of taxable income for which it was computed, is the special rate. If the resulting rate is less than ten percent the applicable rate shall be ten percent.

Article 30 Tax on sale of movable or immovable property (1) Except by inheritance and as mentioned in Article (23) of this Law, the price of sale or transfer of immovable property is subject to a fixed tax of one percent at the time of transfer of ownership in lieu of income tax.

(2) The price of sale or transfer of movable property or a vehicle is subject to a fixed tax of two percent at the time of transfer of ownership in lieu of income tax. 


\section{CHAPTER IV \\ PARTNERSHIPS}

Article 31 Definitions

1. A partnership is an association of two or more persons joining under an agreement, in accordance with the provisions of the relevant laws, to carry on business and share the profit or loss.

2. A partner is a person who has a share in the partnership.

3. The partnership agreement is the body of provisions agreed to by the partners under which they operate the partnership.

4. A general partnership (Sherkat-Tazamoni) is one in which the partners are liable for payment of all debts of the partnership individually and collectively.

5. A special partnership (Sherkat-Tazamoni-Mekhtalet) is one in which one or more partners have unlimited liability for debts of the partnership and the rest of the partners have liability limited to their shares of capital in the partnership.

6 A limited liability company (Sherkat-Mahdudul Masseliat) is a partnership in which the partners are not individually liable for debts of the company but each partner has liability limited to his shares of capital in the company.

7 A corporation (Sherkat-Sahami) is a partnership which has its capital determined and divided by shares and liability of each partner is limited to his shares.

Article 32 Limited liability company and special partnership

(1) A limited liability company is subject to the same provisions of this Law as

corporations (Sherkat-Sahami). Partners in such companies are

considered shareholders and distributions of earnings are considered

dividends for purposes of this Law.

(2) A special partnership is subject to the same provisions of this Law as a

general partnership.

Article 33 General partnerships

A general partnership as a legal entity is not subject to the income tax imposed by this Law. Partners as natural persons are liable for income tax only in their separate and individual capacities. The

income of the general partnership is taxable as income of the partners

individually, each of whom is required to include his share of the partnership

income in his taxable income.

Article 34 Determination of net income

Every general partnership is required

to make an annual report of all its receipts, expenses, and disbursements,

and to determine its net income in the same manner as an individual. The

partnership is required to report separately for each partner his share of the following items:

1. the net income or net loss;

2. the gains or losses from sale or exchange of movable and immovable property; and

3. salary, interest, dividends, advances, etc.

Article 35 Distribution of receipts

The income, expenses, and net earnings of a

general partnership shall be deemed to have been shared by the partners

according to the terms and conditions of the general partnership agreement. 


\section{CHAPTER V \\ RULES FOR ACCOUNTING}

Article 36 Maintenance and preservation of records

All natural or legal persons with taxable income in a taxable year shall keep records of all

transactions, of all movable and immovable property, and of all income.

Such records shall be preserved by the owner and be available to the

Ministry of Finance upon request.

Article 37 Accrual method of accounting

Corporations and limited liability companies shall compute their income using the accrual method of accounting which recognizes income and expenses when due.

Article 38 Cash method of accounting

A person shall compute his taxable income using the cash method of accounting at the time of income receipt and expense payment. The Ministry of Finance may permit a taxpayer to

compute his taxable income using the accrual method of accounting. Corporations and limited liability companies are excluded from this provision. Deductions for depreciation are allowable in accordance with the Income Tax Manual.

Article 39 Form and content of records

The Ministry of Finance is authorized to prescribe the records that shall be kept by any taxpayer or class of taxpayers to reflect income clearly and to require such reports as it deems necessary to administer the income tax.

Article 40 Inventory at the close of year

Inventories of goods, products, and materials used in business shall be taken at the close of each taxable year and priced at cost or market value, whichever is lower. All taxpayers engaged in manufacturing, trade, or other businesses are required to take inventories on such basis as the Ministry of Finance may prescribe.

Article 41 Tax determination of two or more businesses

In the case two or more organizations, trades or businesses are owned or controlled directly or indirectly by the same natural or legal person, the Ministry of Finance may

distribute, apportion or allocate receipts, deductions or credits between or among such organizations, trades or businesses to reflect accurately the taxable income and prevent evasion of taxes.

\section{CHAPTER VI \\ SPECIAL PROVISIONS RELATING TO CORPORATIONS AND LIMITED LIABILITY COMPANIES}

Article 42 Deduction of operating loss

(1) A corporation or limited liability company incurring a net operating loss in a taxable year shall be entitled to deduct this loss from its taxable income of three succeeding years, deducting each year one-third of the loss. Paragraph 4 of Article 47 of this Law is an exception to this provision.

(2) Where a resident company carries on activities that are intended to generate income from a source outside of Afghanistan, the company shall determine its taxable income as defined in Article (12) of this Law or its net operating loss as defined in paragraph (1) of this Article separately in respect of the activities that are intended to generate income from a source in Afghanistan and its activities that are intended to generate income from a source outside of Afghanistan. A net operating loss from activities that are intended to generate income from a source outside of Afghanistan may only be carried forward and deducted from taxable income from such activities and 
may not be deducted from taxable income from a source in Afghanistan.

Article 43 Distribution of assets to shareholders

Except payments of dividends, and except when made in connection with liquidation of a corporation or a limited liability company, the distribution of the assets of the corporation or limited liability company to its shareholders or partners shall be treated by the shareholder or partner as a reduction in the cost of his stock or capital share.

Article 44 Distribution of assets at the time of liquidation of company A distribution of assets among shareholders or partners in connection with the liquidation of a corporation or a limited liability company shall be treated by the shareholder or partner as proceeds from sale or exchange of assets as provided in Chapter III of this Law. The amount distributed in money plus the market value of any other assets distributed less the shareholder's cost of the stock or the amount of partner's capital on which distribution is made is taxable income of the shareholder or partner. No gain or loss shall be recognized to the corporation or limited liability company on the distribution of its assets in partial or total liquidation.

Article 45 Distribution of money or other assets

A dividend is any distribution of money or assets made by a corporation or a limited liability company to its shareholders or partners out of earnings. Dividends are subject to the following provisions:

1. Dividends paid in cash by a corporation or limited liability company which is organized under the laws of Afghanistan are deductible from the income of the company which makes the payment except where paragraph 2(2) of Article 18 applies.

2. Dividends paid in the form of securities of any kind are not deductible from income of the corporation or limited liability company. 3. Dividends paid in money are taxable income of the recipient at the time received, but dividends in the form of securities of any kind are not considered taxable income of the recipient at the time received.

Article 46 Withholding tax

(1) A profit or non-profit legal person organized under

the laws of Afghanistan is required to withhold income tax as follows:

1. in the case of wages and salaries, in accordance with the provisions of this Law; 2. $20 \%$, in the case of interest, dividends, royalties, or similar income subject to provisions of this Law

(2) Tax withheld under this Article is to be paid to the State no later than 10 days after the end of the month in which the tax was withheld.

(3) No later than the last day of Hamal, a legal person making payments subject to withholding tax under the provisions of the Law shall provide each person receiving amounts that have been subject to withholding tax with details of payments and withholding tax in the manner prescribed by the Ministry of Finance.

(4) No later than 10 days after the end of each month, a person making payments subject to withholding tax shall provide details of payments and withholding tax to the Ministry of Finance in the manner prescribed by the Ministry of Finance.

(5) Where the correct amount of tax has been withheld from an amount in accordance with the provisions of this Law, it is deemed that the income tax on this amount has been fully satisfied.

(6) A natural person who has income from more than one source is required to file a tax return and income tax shall be computed based on provisions of this Law. Any amount of tax which has been withheld on payment of the income will be allowed as a credit deductible against income tax otherwise payable. 
Article 47 Deduction of depreciation and losses

(1) From 21 June 2004 and as an exception to paragraph 1 (7) of Article 18 of this Law, an approved enterprise registered under the Law on Domestic and Foreign Private

Investment in Afghanistan shall be entitled to a deduction for the depreciation of capital assets as follows:

- four years for buildings; and

- two years for other capital assets.

(2) The depreciation deduction for buildings and other capital assets shall be an equal deduction for each fiscal year of depreciation. If a capital asset is owned by the enterprise for less than one half of the year, a deduction for half the annual amount will be allowed in that year.

(3) The depreciation deduction shall only apply to capital assets acquired and first used in the year in which the enterprise became an approved enterprise or registered enterprise (whichever is earlier) or in the following two years.

(4) From 21 June 2004 and as an exception to Article 42 of this Law, an approved enterprise that incurs a net operating loss in a fiscal year based on legal records and accounting records may carry this loss forward as a deduction from taxable income in each subsequent year until the loss is fully extinguished. The loss incurred by such approved enterprise shall be calculated in accordance with Article 42 of this Law. Depreciation and expenditure which relate to a period covered by a tax exemption or to a period before an enterprise first became an approved enterprise cannot be used in the calculation of a net operating loss.

\section{CHAPTER VII \\ TAXATION OF INSURANCE COMPANIES}

Article 48 Provisions for applicable insurance companies

The Articles of this Chapter apply to an insurance company provided it meets the following conditions:

1. It shall have been organized as a corporation under the laws of Afghanistan.

2. The company is engaged in more than one field of insurance, such

as casualty-risk insurance, life insurance, or any other type of insurance activity,

3 The company must have separate accounting and reserves for each

of its fields of insurance and other activities.

Article 49 Taxable income of insurance companies

The following receipts of insurance companies are subject to income tax:

1. Interest, dividends, rent, and other income from investments and property;

2. all receipts from activities other than insurance;

3. all premiums for insurance against fire, theft, accident, sickness,

casualty, or risk, the insurance of which is for a specified term, and

the insured person has no money claim after the term has expired; and

4. income from capital transactions.

Article 50 Exemption of certain policy holders

All insurance premiums received for written contracts that require ultimate payment of specified

benefits to the policyholder or his beneficiaries are exempt from income tax.

Article 51 Non-deductible expenses of insurance companies

The following expenses and payments made in connection with insurance for which

premium income is tax exempt under Article 50 are not deductible:

1. Commission expense and other costs of writing insurance; and

2. Payments of benefits to the policyholders or their beneficiaries.

Article 52 Deductible expenses of insurance companies

(1) The following expenses and payments of insurance companies are deductible from their 
income:

1. claims paid on insurance for which premium income is taxable;

2. commissions and other costs of writing insurance for which premium income is taxable;

3. reinsurance costs of insurance for which premium income is taxable;

4. additions to reserves for compensation of claims, provided

such reserves do not exceed 100 percent of premiums for

transport insurance and 50 percent of premiums for any

other risk insurance received during the taxable year;

5. additions to reserves for losses in operations in the field of

insurance for which premium income is taxable, provided

such reserves do not exceed twice the amount of invested capital for such field of insurance;

6. all necessary expenses of doing business as provided in

Chapter II of this Law except those cited in Article 51.

(2) Any transfers or payments from reserves referred to in sub-paragraphs

(4) and (5) of paragraph 1 of this Article, except for actual claims and losses

or for dividend payments in money, are taxable income in the taxable year

during which the transfer or payment was made.

Article 53 Determination of taxable income of foreign insurance companies Any

foreign insurance company or underwriter receiving premium income of any

kind from within Afghanistan is subject to income tax as follows:

1. the premiums received by the company from within Afghanistan in

the taxable year shall be determined;

2. the total premiums received world-wide by the company in the same period shall be determined;

3. the net income amount before income tax and dividend payments of

such company from its world-wide business shall be determined;

4. the amount determined in sub-paragraph (1) divided by the amount

determined in sub-paragraph (2) multiplied by the amount

determined in sub-paragraph (3) shall be taxable income.

\section{CHAPTER VIII \\ TAXATION OF BANKS, LOAN AND INVESTMENT CORPORATIONS}

Article 54 Gains subject to tax

Income of banks, loan and investment corporations

are subject to income tax on all income from dividends, interest, discounts,

rents, service charges, fees, commissions, and on gains from capital transactions.

Article 55 Deduction of necessary expenses

Necessary and ordinary business

expenses are deductible from the income described in Article 54 of this

Law. Losses from capital transactions, dividends paid in money and

additions to a reserve against losses on loans are also deductible.

Article 56 Additions to reserves

Additions to reserves against losses on loans

are deductible only if such reserve does not exceed 25 percent of loans

outstanding at the end of the taxable year. Any transfers or payments from

such reserve, except in accordance with the purpose of the reserve, is

taxable income in the year the transfer or payment was made.

Article 57 Increase or decrease in value of securities

An increase or decrease in value of securities owned, loans and similar items is not recognized

for the purposes of this Law until realized through sale or exchange of

the securities. When gain or loss is realized through sale or exchange of

the securities, such gain or loss shall be income or loss in the year in which

the sale or exchange took place. 


\section{CHAPTER IX WITHHOLDING TAXES ON INCOME SOURCES}

Article 58 Withholding and payment of tax

All natural or legal profit and non profit

persons, ministries, state enterprises, municipalities and other State

departments employing two or more employees in any month of a year are

required to withhold taxes as provided in Article 4 of this Law from all salary

and wage payments and pay the amount withheld to the Government account.

Article 59 Rent withholding tax on buildings and houses

(1) Payments of rent for buildings and houses which are rented to legal persons or natural persons

and are used for business purposes or offices where the monthly rent is

more than 15,000 afghanis are subject to a 20 percent income tax.

(2) Tenants of buildings and houses mentioned in paragraph (1) of this

Article are required to pay taxes according to the rulings issued by the Ministry of Finance.

(3) Tax collected under paragraph (1) of this Article is paid by the tenant in

respect of the income tax liability of the landlord under this Law. This tax

shall be treated as a prepayment of the tax liability of the landlord and shall

be credited at the time of annual tax payment. In the event of a dispute

about the amount of rent owed by a tenant, the tenant will be treated as

having paid to the landlord as rent any tax that was paid to the relevant

authorities under this Article.

(4) Payments for rental services include:

- any money, goods or services or any other benefit received

by a person or persons for rental services; and

- the cost of any repairs, renovations or improvements to the property carried out by the tenant.

(5) If the rental payment of a property is less than the actual rental value of

the property, the Ministry of Finance by its authorized panel will calculate

the rent according to the market value.

(6) Property dealers are required to send a copy of the agreement to the

Ministry of Finance as soon as it is signed. If a property dealer makes a

false agreement or delays sending the agreement, the Ministry of Finance

will officially notify the Ministry of Justice to take necessary action.

(7) Where it is proven that the rent in a lease agreement is more than 20

percent lower than the market value rent, paragraph (5) of this Article will be

applied. In the case of a dispute on market value of the rent, the onus is on

the landlord to prove that the rate fixed by the Ministry of Finance is not

correct. This provision applies where the Ministry of Finance finds evidence

and documents which show that the rent mentioned in the contract is less

than what is paid. In this case, the Ministry of Finance may require the

landlord to lease the property to the Ministry of Finance at the end of the

current lease for a period twice the period set out in the current lease for the

rental price set out in the current lease.

(8) If the tax has not been paid within 15 days of the due date, the following rules will apply:

1. Subject to a notice in writing by the Ministry of Finance, the

right of the landlord in a lease agreement or similar contract

to receive payment for rental services shall be treated as if it has been temporarily transferred to the Ministry of Finance

as representative of the Government of Afghanistan;

2. If the tenant has not paid the tax due within 30 days after

receiving notice from the Ministry of Finance of the amount

overdue, the right of the landlord in a lease agreement or

similar contract to evict tenants for non-payment of rent shall

be treated as if it has been transferred to the Ministry of 
Finance as representative of the Government of Afghanistan;

This arrangement will remain in place until the Ministry of

Finance receives the rental tax due and any additional

income tax payable in accordance with Chapter XVI of this law.

Article 60 Remittance of tax payments

Any employer required to withhold

taxes by Article 58 of this Law is required to remit to the State the amount

withheld no later than 10 days after the end of the month in which the

amounts were withheld. The employer shall submit with this remittance a

Tax Withholding Report in such form as is prescribed in the Income Tax

Manual of the Ministry of Finance.

Article 61 Preparation of statements

(1) As prescribed by the Ministry of Finance,

each employer required to withhold tax from salaries or wages shall prepare a

salary and tax statement for each employee and submit the statement to the

Ministry of Finance or relevant tax office and employees no later than the end

of the first month of the following year.

(2) Every employer prescribed in paragraph (1) of this Article is required to file an annual summary report of taxes withheld from salaries and wages in the form and at the time and place prescribed by the Ministry of Finance.

Article 62 Time for submission of statements (1) Every taxpayer is required to present his annual salary and tax statement to the relevant tax office within

one and half months after the end of the fiscal year.

(2) The income tax liability for a taxable year is discharged by a taxpayer

filing his salary and tax statement, certified by his employer, within one and

half months after the end of the taxable year, provided the taxpayer meets the following conditions:

1. The taxpayer has no taxable income in the taxable year

other than the salary or wage from which taxes were withheld;

2. The taxpayer was not employed during the taxable year by

more than one employer; and

3. The taxes withheld were in accordance with income tax rates

prescribed in paragraph 3 of Article 4 of this Law.

Article 63 Submission of return

(1) Any taxpayer with income from salaries or

wages subject to tax withholding from more than one employer or has

income from sources other than salaries or wages shall file an income tax

return as required by the provisions of this Law. The taxes withheld shall be

allowed as a credit against the taxpayer's tax liability.

\section{CHAPTER $X$ BUSINESS RECEIPTS TAX}

Article 64 Business receipts tax

(1) The business receipts tax is imposed on

the business activities of limited liability companies, corporations, general

partnerships and organizations.

(2) Natural and legal persons deriving 100,000 afghanis or more income per

month from providing taxable services mentioned in paragraph (2) of Article

65 of this Law are subject to tax mentioned in sub-paragraph 1 (6) of Article 65 of this Law.

Article 65 Rates of business receipts tax

(1) The business receipts tax is collected from limited liability companies, corporations, general partnerships and organizations as follows: 
1. Five percent of the gross receipts (before any deductions) during the fiscal year of commissions, fees, interest, dividends, rent, royalties, and similar income. However, the business receipts tax does not apply to the rental income of a natural person from which tax has been withheld under Article 59 of this Law.

2. Two percent of the gross receipts (before any deductions) during the fiscal year for materials, equipment, services, transportation, and construction of buildings provided under terms of a contract.

3. Two percent of the gross receipts (before any deductions) during the fiscal year from premium income for insurance.

4. Two percent of the gross receipts (before any deductions) during the fiscal year from sale of admissions to public entertainment including cinema shows, plays, concerts, exhibitions, sports and others of the same kind.

5. Two percent of the gross receipts (before any deductions) during the fiscal year from sales of products, goods, assets, and other services.

6 . Ten percent of the income derived from the services provided by a legal or natural person which is 100,000 afghanis or more per month in accordance with rulings issued by the Ministry of Finance.

(2) Taxable services mentioned in sub-paragraph (1) 6 of this Article are guest house and hotel services, restaurant services, telecommunications services, and airline services:

"guest house and hotel services" means the provision of sleeping accommodation and related services, including the provision of meals, beverages, laundry and communications services, to persons who occupy such accommodation as transient guests;

"restaurant services" means the provision of food or beverages by an establishment that provides facilities for immediate consumption at that establishment, or catering services of prepared food; or sales of cooked foods that were prepared on the premises; "telecommunications services" means the provision of telephonic services or internet services by a telecommunications service provider or internet service provider, including digital or analogue telephone, facsimile or data transfer communications, and internet access by any means; "airline services" means passenger air services where the flight originates in Afghanistan.

(3) Total income of a business entity is not severable.

(4) The monthly receipts of a person for the provision of taxable services include money, goods and services. The cost of goods and services are computed in afghanis according to market value.

(5) Where a taxpayer referred to in paragraph 1 (6) of this Article claims that it does not have income from taxable services for one or more months, the person is required to inform the Ministry of Finance in writing and attach with a completed tax return. Where the claim is true, the person will not be subject to business receipts tax under the paragraph 1(6) of this Article. If the claim is not true then, in addition to the business receipts tax payable under paragraph 1(6) of this Article, the person will be required to pay the additional tax provided in paragraph 2 of Article 103 of this Law.

Article 66 No effect of profit or loss on business receipts tax Business receipts tax is payable on total receipts and is not affected whether the taxpayer has a profit or loss during the current or previous years. 
Article 67 Deductible amount

The business receipts tax paid or payable shall be a

deductible expense in computing taxable income for the same taxable year.

\section{CHAPTER XI \\ FIXED TAXES}

Article 68 Fixed tax on commercial activities

Persons who are engaged in commercial activities or who own the properties described in this Chapter are subject to fixed tax.

Article 69 Payment of fixed tax

Fixed taxes are due and payable during the taxable year unless otherwise provided in this Law.

Article 70 Fixed tax on imports

(1) Persons who import goods and have a

business license are subject to two percent fixed tax on the total cost (including custom duties) of the goods imported. The tax paid will be allowed as a credit in the calculation of the person's annual income tax assessment in accordance with the provisions of this Law.

(2) Persons who import goods without having a business license are subject to three percent fixed tax on the total cost (including customs duties) of the goods imported in lieu of income tax on such activities.

(3) Persons who import goods and have an interim business license but do not provide their business declaration form to the Ministry of Finance are subject to three percent fixed tax on the total cost (including customs duties) of goods imported in lieu of income tax on such activities.

(4) The tax mentioned in the paragraphs of this Article shall be paid at the customs house where customs duties of the goods are paid.

Article 71 Fixed tax on exports

(1) Persons who export goods and have a business

license are subject to two percent fixed tax on the total cost (including custom duties) of the goods exported. The tax paid will be allowed as a credit in the calculation of the person's annual income tax assessment in accordance with the provisions of this Law.

(2) Persons who export goods without having a business license are subject to two percent fixed tax on the total cost (including customs duties) of the goods exported in lieu of income tax on such activities.

(3) Persons who export goods and have an interim business license but do not provide their business declaration form to the Ministry of Finance are subject to two percent fixed tax on the total cost (including customs duties) of the goods in lieu of income tax on such activities.

(4) The tax mentioned in the paragraphs of this Article shall be paid at the customs house where customs duties of the goods are paid.

Article 72 Fixed tax on transport

Persons who transport passengers or goods for business purposes are required to pay an annual tax as follows, before renewal of their vehicle registration:

\section{Vehicles based on tons}

1 From 1 up to 2 tonnes 2600 afs

2 Over 2 up to 3 tonnes 3400 afs

3 Over 3 up to 4 tonnes 4200 afs

4 Over 4 up to 5 tonnes 5000 afs

5 Over 5 up to 6 tonnes 6000 afs 
6 Over 6 up to 8 tonnes 7500 afs

7 Over 8 up to 10 tonnes 9000 afs

8 Over 10 up to 12 tonnes 10500 afs

9 Over 12 up to 14 tonnes 12000 afs

10 Over 14 up to 16 tonnes 13500 afs

11 Over 16 up to 18 tonnes 15000 afs

12 Over 18 up to 20 tonnes 16500 afs

13 Over 20 up to 25 tonnes 18500 afs

14 More than 25 tonnes 18500 afs and 500 afs per additional tonne

15 More than the total allowable tons of a trailer Over $500 \mathrm{~kg}$ then 200 afs per onne

\section{Passenger vehicles}

1 Taxi with capacity of 3 to 5 passengers 2000 afs

2 Taxi with capacity of more than 5 Passengers 2000 afs and 200 afs per additional seat

3 Microbus with up to 14 seats 2600 afs

4 Other buses from 15 up to 21 seats 4000 afs

5 Other buses from 22 up to 29 seats 6000 afs

6 Other buses from 30 up to 39 seats 7000 afs

7 Other buses from 40 up to 49 seats 7500 afs

8 Other buses from 50 up to 60 seats 8000 afs

9 Other buses with more than 60 seats 8000 afs and 200afs per additional seat

Vehicles according to their cylinders

14 cylinders 1500 afs per vehicle

26 cylinders 2000 afs per vehicle

38 cylinders 3000 afs per vehicle

4 More than 8 cylinders 3000 afs and 500afs per additional cylinder

\section{Rickshaw}

1 Motorbike rickshaw 500 afs

2 Rickshaw 1000 afs

Article 73 Fixed tax of government contractors

Persons who provide supplies, materials, services or construction under contract to the State or its agencies without a business license are subject to a seven percent fixed

tax in lieu of taxes on income from such activities. Fixed tax is to be withheld from the amount to be paid.

Article 74 Fixed tax of exhibitions

Legal persons not subject to taxation under Chapter $\mathrm{X}$ of this Law or persons who are the owners of cinemas, theaters, exhibitions, or other places of entertainment and who at the same time operate such places, are subject to a fixed tax of ten percent of receipts from sale of admissions. This fixed tax is in lieu of income tax for such business. The fixed tax on admissions sold during each month is to be paid before the sixth day of the following month at the tax office of the district in which the showing took place.

Article 75 Fixed tax of grain and processing mills, cane and seed oil machinery (1) Owners of mills grinding grains or processing rice, cane or seed oil extracting machines are subject to a fixed tax in lieu of taxes on income from such property. This tax shall be ten percent of the estimated gross income per year from such mills or machines. The estimated gross income per year shall be determined in accordance with Income Tax Manual of the Ministry of Finance and the tax shall be paid by the owner at the tax office of the district in which the mill or machine is located.

(2) Owners of mills and saw mills with machines which operate by electric or 
diesel or similar power are subject to a fixed tax in lieu of income tax on the income from such mills. The fixed tax is equal to 400 afghanis per year per horse power of the motors or machines providing power for the mill. The tax shall be paid by the owner of the mill at the tax office of the district in which the mill is located.

Article 76 Fixed tax of place of business

All persons selling goods and services

from established places of business are subject to taxes specified under the provision of the Article 77 of this Law. These taxes are in lieu of income taxes. This tax shall be paid by the owner or owners of the business at the tax office of the district in which the business establishment is located.

Article 77 Determination of fixed tax on place of business

(1) The fixed tax of business establishments is to be set by a committee considering the following factors and is to be approved by the Minister of Finance every three years:

1. The kind of goods and services offered;

2. The estimated volume of business;

3. The size and rental value of the establishment;

4. The economic advantages of its location in relation to the population;

5. Demand for goods and services offered;

6. Estimation of turnover, cost of goods and sales of goods;

7. Classification between domestic and foreign products;

8. Classification between consumable and non-consumable goods;

9. Estimation of daily, monthly and annual net income of the business establishment.

(2) A fixed tax is imposed on business establishments which do not have

complete accounting documents, and is computed according to the following categories:

1. The fixed tax of business establishments which have reliable

purchase documents is three percent of the total annual purchases.

2. The fixed tax of business establishments which have reliable

sales documents is two percent of the total annual sales.

3 . The fixed tax of business establishments which are not

covered by sub-paragraphs (1) and (2) of this paragraph is

2.5 percent of the estimated total annual sales.

4. The fixed tax of business establishments whose calculation

of annual net income is not possible is six percent of the

market value of current stock on hand.

Article 78 Fixed tax of physicians

(1) Physicians or medical practitioners

who treat patients outside of State hospitals are required to pay an annual

fixed tax in lieu of income tax as follows:

1. 6,000 afghanis for physicians or medical practitioners who have up to 10 years of experience,

2. 10,000 afghanis for physicians or medical practitioners who have more than 10 years and up to 20 years of experience,

3. 15,000 afghanis for physicians or medical practitioners who have more than 20 years of experience.

(2) The fixed taxes mentioned in paragraph (1) of this Article are collected

by the relevant section of the Ministry of Public Health while issuing or

renewing medical treatment licenses.

(3) Where a person does not pay the tax due under paragraph (1) of this

Article, the person's clinic or office will be closed by officials of the Ministry

of Finance until the tax due has been paid.

Article 79 Amendments to exemptions

(1) Amendments to exemptions and tax rates of this Law must be proposed by the Ministry of Finance and approved by the authorized officials.

(2) Tax imposition and exemptions are not valid without the approval of the Ministry of Finance. 
Article 80 Fixed tax on persons without fixed place of business

Persons with no fixed place of business and not otherwise taxed under the provisions of this

Law are subject to fixed occupational tax in accordance with the provisions

of Article 81. Fixed occupational tax is payable to the nearest tax office of

the district in which the person resides.

Article 81 Fixed tax of brokers and commission agents

Persons who are brokers, commission agents, or sellers of goods and similar businesses

without a fixed place of business shall pay tax according to the rates determined by the Ministry of Finance.

\section{CHAPTER XII \\ TAXATION RULES FOR QUALIFYING EXTRACTIVE INDUSTRY TAXPAYERS}

Article 82 Definitions

(1) In this Chapter:

1. a "hydrocarbons Contract" means an Exploration Contract or

Service Contract described in any applicable law affecting hydrocarbons in Afghanistan;

2. a "mining Authorization" means an Authorization described in Article 18 of the Minerals Law, 2005;

3. a "mining License" means a License described in Article 18 of the Minerals Law, 2005;

4. a "QEIT" means a Qualifying Extractive Industries Taxpayer and refers to a person that holds a mining License or mining

Authorization or is party to a hydrocarbons Contract;

5. a "QEIT asset" is an asset that -

has an effective life greater than 12 months; and

is constructed or acquired to be used directly in the

business subject to a mining License or mining

Authorization or a hydrocarbons Contract.

(2) A well that is drilled by a QEIT for the purpose of exploring for, developing, or producing hydrocarbons is deemed to be a QEIT asset and all costs

incurred in the course of drilling the well, contracting with another person to

drill the well for the QEIT, or closing a well are treated as the cost of acquiring

the well. Where the drilling or contracting costs for drilling are incurred over

more than one fiscal year, the QEIT is treated as acquiring separate QEIT

assets in each year with a cost for each asset equal to the drilling or

contracting costs for drilling incurred in that year.

Article 83 Precedence of Chapter XII

The Articles in the Chapters of this Law apart

from this Chapter apply to a QEIT in the same manner they apply to a

taxpayer that is not a QEIT unless they are changed by an Article in this Chapter.

Article 84 QEIT is treated as a separate taxpayer in respect of each Authorization, License, or Contract (1) If a QEIT is party to more than one hydrocarbon Contract or holds more than one mining License, or mining Authorization, or any combination of these, the person is treated as if it were a separate person in respect of the business operations related to each hydrocarbon Contract, mining License, or mining Authorization.

(2) If a hydrocarbon Contract, mining License, or mining Authorization is renewed, the renewal is treated as part of the original hydrocarbon Contract, mining License, or mining Authorization for the purpose of this Article.

(3) If a QEIT is party to more than one hydrocarbon Contract or holds more

than one mining License, or mining Authorization, or any combination of these

and incurs expenditure in relation to more than one hydrocarbon Contract, 
mining License, or mining Authorization, the expenditure is apportioned

between the different parts of the business on the basis of the application of the expenditure.

Article 85 Business Receipts Tax

The Business Receipts Tax imposed under Chapter X of this Law does not apply to:

1. receipts of a QEIT from the sale of Mineral Substances (as

defined in the Minerals Law, 2005) that are subject to a mining

License or mining Authorization;

2. receipts of a QEIT from the sale of hydrocarbons that are

subject to a hydrocarbons Contract; or

3. receipts of a QEIT from the sale or transfer of a mining License

or mining Authorization or a hydrocarbons Contract.

Article 86 Depreciation deductions

(1) Contrary to paragraph 1 (7) of Article 18 of

this Law, a person that is a QEIT and that incurs an expense to acquire a

QEIT asset other than a building or rights to occupy a building may deduct the

cost of acquiring the asset on a straight-line basis over the lesser of:

1. the effective life of the asset; and

2. five years commencing with a deduction in the year in which the asset is acquired.

(2) Contrary to paragraph 1 (7) of Article 18 of this Law, a person that is a

QEIT and that incurs an expense other than annual rent to construct or

acquire a QEIT asset that is a building or to acquire rights to occupy a building

may deduct the expense on a straight-line basis over 15 years, commencing

with a deduction in the year in which the expense is incurred.

(3) A person that is a QEIT that incurs an expense to acquire a mining

Authorization or mining License or hydrocarbons Contract may deduct the

cost of acquiring the Authorization, License or Contract on a straight-line basis

over the period to which the Authorization, License or Contract applies.

(4) The depreciated value of a QEIT asset at any time is the original cost less

any deductions for the cost of constructing or acquiring the asset that were

allowed under this Article. Where a person that is a QEIT disposes of a QEIT

asset for more than its depreciated value, the excess of sale proceeds over

depreciated value is included in the person's income for tax purposes. Where

a person that is a QEIT disposes of a QEIT asset for less than its depreciated

value, the excess of depreciated value over sale proceeds is deductible in the year of sale.

Article 87 Cost of constructing roads

(1) This Article applies to a person that is a

QEIT and that incurs an expense to construct a road that will be used to carry

on a business that is subject to a mining License or mining Authorization or a

hydrocarbons Contract.

(2) A person described in paragraph (1) of this Article may deduct the cost of constructing the road described in paragraph (1) of this Article over a period of

fifteen years commencing with a deduction in the year in which the road is completed.

(3) This paragraph applies where a person that is a QEIT sells its rights under

a mining License or mining Authorization or hydrocarbons Contract to another

person and as a result of that transfer the person making the sale will no

longer use a road described in paragraph (1) of this Article and the person

acquiring the mining License, mining Authorization or hydrocarbons will use

the road. In this situation, the person acquiring the mining License, mining

Authorization or hydrocarbons Contract asset is entitled to deduct the

undeducted cost of constructing the road over the remaining deduction years.

For this purpose, the remaining deduction years for the road is calculated as

15 minus the number of years during which the previous owner or owners

were entitled to deductions under this Article. 
(4) Where paragraph (3) of this Article applies to a road described in paragraph (1) of this Article, the person who sells its rights under a mining License, mining Authorization or hydrocarbons Contract is not entitled to any deductions under this Article for the cost of constructing the road the year in which the rights under the mining License, mining Authorization or hydrocarbons Contract are sold or in any later year.

Article 88 Pre-production costs

(1) Notwithstanding Article 18 of this Law, a

person that is a QEIT may only deduct an expenditure that is a pre-production cost on a straight-line basis over the pre-production cost recovery period where -1. a "pre-production cost" is any expenditure that is incurred by a QEIT prior to commencing commercial production of minerals in the course of business related to a mining License or mining Authorization or a hydrocarbons Contract. However, a preproduction cost does not include the cost of acquiring a QEIT asset or the cost of constructing a road;

2. the "pre-production cost recovery period" for a mining business carried on by a QEIT in an area defined in a mining License or mining Authorization is the lesser of -

15 years; and - the number of years remaining in the License or Authorization' 3. the "pre-production cost recovery period" for a hydrocarbon business is the number of years remaining in the Contract.

(2) A QEIT is treated as commencing commercial production of minerals or hydrocarbons in the earlier of:

1. the year in which the Ministry of Finance and the Minister of Mines and Industries issue to the QEIT a written notification that the Ministries jointly accept a written submission by a QEIT that it has commenced commercial production, and 2. in the case of a QEIT that holds a mining Authorization, the year in which the proceeds from the sale of minerals exceeds 6 percent of the pre-production costs incurred by the QEIT prior to that year, 3. in the case of a QEIT that holds a hydrocarbons Contract, the year in which the proceeds from the sale of hydrocarbons exceeds the threshold percentage of the pre-production costs incurred by the QEIT prior to that year where the number in the threshold percentage is determined by dividing 100 by the number of years of the hydrocarbons Contract.

(3) Where a person that is a QEIT sells its rights in a mining License or mining Authorization or hydrocarbon Contract to another QEIT, the first QEIT may add to the cost of acquiring its rights in the License, Authorization or Contract any pre-production expenses it incurred that have not been previously deducted under paragraph (1).

Article 89 Deduction for contributions to a fund for environmental and social obligations A person that is a QEIT may deduct any amount that is required to be paid in respect of environmental and social obligations under Article 82 of the

Minerals Law, 2005 or pursuant to a plan required by any applicable law affecting hydrocarbons provided -

1. the amount is paid to an entity that has no direct or indirect connection to the person claiming a deduction under this Article;

2. the person provides, through a financial institution approved for this purpose by the Da Afghanistan Bank, a bank guarantee for payment to the Ministry of Finance of the deductible amount in the event the entity holding the amount deposited does not apply the funds as specified in the governing Minerals 
Regulations or pursuant to a plan required by any applicable law affecting hydrocarbons.

Article 90 Loss carry-forward and stability agreements

(1) Article 42 of this Law, which

imposes a limit on the recognition of net operating losses, does not apply to a

QEIT. Where a QEIT incurs a net operating loss as defined in Article 47, the

loss may be treated as a deductible expense in the following year.

(2) Subject to paragraph (3) of this Article, the Ministry of Finance shall apply

to a QEIT the provisions of this Law as they stood at the time the QEIT

became party to a mining Authorization, mining License, or hydrocarbons

Contract for a period of:

1. 5 years, in the case of a QEIT holding a mining Authorization, commencing in the year in which the QEIT begins to hold the Authorization;

2. 8 years, in the case of a QEIT holding a mining License,

commencing in the year in which the QEIT beings to hold the License; or

3. the period of the hydrocarbons Contract, in the case of a QEIT

that is party to a hydrocarbons Contract.

(3) The Ministry of Finance shall only apply the provisions of this Law to a

QEIT as set out in paragraph (2) where the QEIT has agreed in writing that

taxable income of the QEIT shall be subject to an income tax rate of $30 \%$ for the years in which the provisions of this Law are applied by the Ministry of Finance on the basis of this Article without regard to subsequent changes.

\section{CHAPTER XIII \\ ASSESSMENT, RETURNS, OBJECTIONS AND PAYMENT OF TAX}

Article 91 Tax Identification Number

(1) Individuals, companies and organizations which are, according to the Income Tax Law and the Customs

Law, required to pay taxes or customs duties; social, non profit and welfare organizations

which are required to withhold taxes from the salaries or wages of their

employees; persons who have an account or open an account with a bank or

other financial institution; and employees whose incomes are subject to

income tax withholding under provisions of this Law are required to have a Tax Identification Number.

(2) Procedures for the issue and use of Taxpayer Identification Numbers will

be prepared by the Ministry of Finance.

(3) Ministries, government agencies and other government organizations shall

not issue or renew business licenses for natural or legal persons who are

required to have a Tax Identification Number but fail to provide it.

Article 92 Assessments and amended assessments

(1) Persons who are subject to

income tax under the provisions of this Law are required to file a detailed

return to report income, deductions, tax withholding, and other necessary

information required by the provisions of this Law and the income tax manual

and submit it to the relevant tax office.

(2) An individual who derives wage income that is subject to income tax

withholding in accordance with the provisions of this Law shall not make a

return unless the person receives wages from two or more employers or the

person has other income in addition to his wage income. The withheld tax

from wages and salaries under the provision of the Law is not refundable.

(3) Where a person has delivered a tax return form required under the provisions of this Law, the tax due if any according to the tax return shall be

treated as an assessment of tax payable and the return shall be treated as a

notice of assessment.

(4) Where the Ministry of Finance believes that the information provided on a tax return does not correctly disclose the tax due, the Ministry of Finance may 
determine the amount of the tax due and issue to the person liable for payment of the tax an amended assessment notice for the amount due. This notice may also be amended if the Ministry of Finance believes it does not correctly show the tax due. The amended notice is treated as a notice of assessment.

(5) Where a person has not prepared and delivered a tax return required under provisions of this Law, the Ministry of Finance may determine the amount of tax due and issue to the person liable for payment of the tax a notice of assessment for the amount due. This notice may be amended if the Ministry of Finance believes it does not correctly show the tax due. The amended notice is treated as a notice of assessment.

(6) The Ministry of Finance may issue an assessment notice or amend an assessment notice only within five years of the date on which the tax return to which the notice relates was due. However, the Ministry of Finance may make or amend an assessment at any time where a person failed to deliver a tax return or delivered an incorrect tax return with the intent of evading tax. (7) Where the Ministry of Finance believes that the collection of tax that will become due is in jeopardy because a person is about to depart from Afghanistan, to cease business, or to transfer property, or for other reasons, the Ministry of Finance may at any time issue an assessment notice for any period in the current or preceding tax year.

Article 93 Submitting returns and payment of tax (1) A person who is required to complete a tax return other than a business receipts tax form must submit their tax return by the end of Jawza (third month) of the next year to the relevant tax office.

(2) Tax specified in an assessment notice is payable on the date specified in the assessment notice.

(3) Residents and non-residents who intend to leave the country before the due date for payment of their tax are required to submit their return form and pay the tax due two weeks before leaving the country.

(4) Income tax payable by persons required to submit a tax return according to the provisions of this Law that is not subject to other payment regulations under this Law must be paid when the tax return is submitted.

(5) A person required to complete a business receipts tax form must complete a tax form for each quarter year. The person must deliver the form and the tax payable for the quarter no later than the fifteenth day of the next month after each quarter year. A business receipts tax form must be delivered by each person who operates a business, regardless of whether or not in one or more months of the fiscal year the person has derived income below the threshold provided in paragraph 1 (6) of Article 65 of this Law.

(6) Unless a different time is provided in this Law, persons who carry on business from fixed business establishments are required to pay their due tax quarterly and the payment for each quarter shall be made no later than the fifteenth day of the month following each quarter.

(7) Persons who own moveable and immovable property shall pay tax due at the time ownership of such property is transferred.

(8) Tax on contracts signed with government agencies, according to Article 73

of this Law, shall be withheld at the time payment is made by the relevant government agency.

(9) Income tax on the gains by brokers shall be paid no later than five days

after the end of the tax year.

(10) The income tax on shows, exhibitions, theaters, cinemas, concerts, sports and similar events shall be paid no later than the fifteenth day of the

next month. If the mentioned shows are not continuous, tax shall be paid after the end of each show.

Article 94 Objections and appeals

(1) Where a person has delivered a tax return required under this Law or has received an assessment notice and that person believes that the tax return or assessment is incorrect, the person can 
request an amendment of the assessment notice within five years of the date on which the tax return was due.

(2) The Ministry of Finance may amend or affirm an assessment notice and will advise the person of its decision.

If the Ministry of Finance has not amended an assessment notice as requested within 60 days after the date on which a person delivered a request for amendment, the earlier assessment notice will be treated as being affirmed. If the person liable to pay the tax assessed in the amended assessment notice or affirmed assessment notice believes that the amended assessment notice or affirmed assessment notice is incorrect, the person may submit to the Ministry of Finance an objection within 30 days after receiving the amended assessment notice or the assessment notice being otherwise affirmed. The objection will be considered by the Objection Review Panel which may affirm or amend the assessment notice in whole or in part.

Where a person does not accept the decision of the Objection Review Panel or the Objection Review Panel has not made a decision with 60 days after receiving the objection, the person may appeal to a court within 30 days after receiving the decision or the assessment notice being otherwise affirmed. The decision of the court will be final.

Article 95 Refunds

If the Ministry of Finance finds, upon examination of a return, claim, or judgment of the Court, that the tax paid is in excess of the amount due, it shall first apply the overpayment against any other taxes or custom duties of the person then due and, with the person's agreement, to another person's tax liability and then refund the excess following procedures set out in the Income Tax Manual.

Article 96 Information collection (1) In order to ascertain the correctness of any return or make an estimate of the income of any person, the Ministry of Finance shall have the power to -

1. examine the books, papers, or records of the person through designated employees of the Ministry of Finance; and

2. require information on the income, expenses, or assets of the person from other persons.

(2) The Ministry of Finance may specify the procedures for examination of a person's books, papers, or records in the Income Tax Manual.

(3) All information collected by the Ministry of Finance on an income tax return and in exercise of the power provided in paragraph (1) of this Article is confidential and may not be disclosed by the Ministry of Finance to anyone outside the Ministry of Finance unless authorized by law.

\section{CHAPTER XIV ENFORCEMENT PROVISIONS}

Article 97 Collection of unpaid tax from third parties

(1) For the purpose of

recovering any tax due by a taxpayer, the Ministry of Finance may, without the agreement of the taxpayer, by notice in writing, require payment from any person:-

1. owing money to the taxpayer; or

2. holding money for the taxpayer; or

3. holding money on behalf of some other person for payment to the taxpayer; or

4. having authority of some other person to pay money to the taxpayer, or

5. who is liable to make payments of salary or wages or other similar payments to a taxpayer. 
Article 98 Liability of directors, shareholders and other persons

Where a company has failed to pay income tax as required under this Law, the Ministry of Finance may collect the tax due from the following persons:-

(1) any or all of the directors of the company who has failed to

exercise care in ensuring the company met its tax liability;

(2) a shareholder of the company with a 10 percent or greater

ownership interest in the company, but only to the extent that the

shareholder received dividends from the company.

(3) a person who has obtained one or more assets from the company

for less than its market value in the course of a transaction that took

place within the three years preceding the date on which the unpaid tax was due.

Article 99 Persons not allowed to leave Afghanistan

(1) A person who has tax due of

more than 20,000 afghanis may be prevented from departing Afghanistan if

the tax due has not been paid to the relevant tax offices. An authorized

person of the Ministry of Finance may issue a notice to the relevant authorities

requesting that those authorities prevent the person from departing Afghanistan.

Article 100 Business closure

(1) Where a person has failed to deliver a tax return,

failed to pay tax on the due date or failed to withhold and pay tax as set out in the provisions of this Law, the Ministry of Finance may notify the person in writing of the intention of the Ministry of Finance to close down part or the whole of the person's business. The Ministry of Finance may issue an order to close down part or the whole of the person's business seven days after the person receives the notice. The order must be signed by an authorized person of the Ministry of Finance and will continue in effect until the person pays the tax due. The Ministry of Interior shall assist with the implementation of this order.

Article 101 Restriction on disposal of property by a taxpayer

(1) Where a person has failed to deliver a tax return, failed to pay tax on the due date or failed to withhold and pay tax as required by the provisions of this Law, the Ministry of Finance may request an order of an appropriate court placing restrictions on a person's movable and immovable property until the person pays the tax due. (2) Where a person does not pay the tax due within 30 days of an order of the court, the Ministry of Finance may request the appropriate court to order the sale of the person's property. Where a person pays tax due under paragraph (1) of this Article before an order of the court for sale of property is issued, the order placing restrictions on the person's property will be withdrawn.

(3) Where paragraph (1) of this Article applies, a court may issue an order to sell a person's property through a public auction.

(4) The Ministry of Finance shall apply the proceeds of the sale of property to the payment of the tax due and any excess of the proceeds shall be paid to the person.

\section{CHAPTER XV ANTI-AVOIDANCE}

Article 102 Transactions between connected persons

If any amount paid or payable in

a transaction between connected persons is different than the amount that

would be paid or payable had the transaction taken place between

unconnected persons, when determining the tax liabilities of the connected

persons, the Ministry of Finance may substitute the amount that would be paid

or payable had the transaction taken place between unconnected persons. 
Article 103 Anti-avoidance

(1) Where any person enters into any transaction or

arrangement or series of transactions or arrangements that have as the main

object or main effect a reduction of liability to pay income tax, the Ministry of

Finance may disregard such transaction or arrangement and assess all

persons affected by the transaction or arrangement as if the disregarded

transaction or arrangement had not taken place.

(2) Any person who evades income tax will be required to pay the income tax due and:

- in the first instance, additional tax of double the evaded tax, and

- in the second instance, additional tax of double the evaded tax and the business activity of the person shall

be ceased by order of the court.

\section{CHAPTER XVI \\ ADDITIONAL TAX AND TAX PENALTIES}

Article 104 Offenses and penalties

(1) A taxpayer may incur an additional income

tax liability and penalties under this Chapter in addition to tax due if the

taxpayer has not complied with tax obligations set out in the provisions of this

Law. The provisions of this Law apply to the assessment and collection of

additional income tax in the same manner as for other tax under this Law.

(2) Additional income tax is payable in the following cases:

1. failure to pay the due tax by the due date,

2. failure to maintain or provide access to records of business transactions,

3. failure to deliver a tax return,

4. failure to withhold tax,

5. failure to pay tax,

6. failure to obtain a Tax Identification Number.

Article 105 Additional income tax where tax is paid late

Where a person has failed to pay tax due by the due date, the person is liable to pay additional income tax of 0.10 per cent of the tax due per day.

Article 106 Additional income tax where records were not maintained

(1) A person who fails without reasonable cause to establish and maintain records required by

the provisions of this Law or fails to provide access to records by Ministry of

Finance officers, shall pay additional income tax of 5,000 afghanis if the

person is a natural person or 20,000 afghanis if the person is a legal person.

(2) A person who fails to establish and maintain records required as a result of

gross negligence or disregard shall pay additional income tax of 10,000

afghanis if the person is a natural person or 40,000 afghanis if the person is a legal person.

(3) A person who deliberately fails to establish and maintain records or

fails to provide access to records by Ministry of Finance officers shall pay

additional income tax of 30,000 afghanis if the person is a natural person or

120,000 afghanis if the person is a legal person.

(4) A person who fails to establish and maintain records as required by

the provisions of this Law with the intent of evading payment of tax, in addition

to the payment of an additional tax under paragraph (3) of this Article, shall be

guilty of an offence and is liable upon conviction by a court to a fine not

exceeding 250,000 afghanis or imprisonment for a term not exceeding two years or both.

Article 107 Additional income tax where a tax return was not filed

(1) A person who fails without reasonable cause to file a tax return by the due date shall pay

additional income tax of 200 afghanis for each day other than holidays that the

return is overdue if the person is a natural person or 1,000 afghanis for each

day other than holidays that the return is overdue if the person is a legal person. 
(2) A person who fails to file a tax return by the due date as a result of gross negligence or disregard shall pay additional income tax of 400 afghanis for each day other than holidays that the return is overdue if the person is a natural person or 2,000 afghanis for each day other than holidays that the return is overdue if the person is a legal person.

(3) A person who deliberately fails to file a tax return by the due date shall pay additional income tax of 800 afghanis for each day other than holidays that the return is overdue if the person is a natural person or 4,000 afghanis for each day other than holidays that the return is overdue if the person is a legal person. (4) A person who fails to file a tax return by the due date with the intent of evading payment of tax, in addition to the payment of an additional tax under paragraph (3) of this Article, shall be guilty of an offence and is liable upon conviction by a court to a fine not exceeding 250,000 afghanis or imprisonment for a term not exceeding two years or both.

Article 108 Additional income tax where tax was not withheld (1) A person who fails to withhold tax as required under the provisions of this Law which apply to payments of dividends, interest, royalties, wages, salaries, rents, commissions, and similar incomes without reasonable cause shall pay additional income tax of 20 per cent of the tax that should have been withheld. (2) A person who fails to withhold tax as required under paragraph (1) of this Article as a result of gross negligence or disregard shall pay additional income tax of 40 per cent of the tax that should have been withheld.

(3) A person who deliberately fails to withhold tax as required under paragraph (1) of this Article shall pay additional income tax of 100 per cent of the tax that should have been withheld.

(4) A person who fails to withhold tax with the intent of evading payment of tax under paragraph (1) of this Article, in addition to the payment of an additional tax under paragraph (3) of this Article, shall be guilty of an offence and is liable upon conviction by a court to a fine not exceeding 125,000 afghanis or imprisonment for a term not exceeding one year or both.

Article 109 Additional income tax where tax was not paid (1) A person who fails to pay tax due under the provisions of this Law without reasonable cause shall pay additional income tax of 20 percent of the tax that should have been paid in addition to the tax payment under the Article 105 of this Law.

(2) A person who fails to pay tax due under the provisions of this Law as a result of gross negligence or disregard shall pay additional income tax of 40 per cent of the tax that should have been paid in addition to the tax payment under the Article 105 of this Law.

(3) A person who deliberately fails to pay tax due under the provisions of this Law shall pay additional income tax of 100 per cent of the tax that should have been paid in addition to the tax payment under Article 105 of this Law. (4) A person who fails to pay tax due under the provisions of this Law with the intent of evading payment of tax, in addition to the payment of an additional tax under paragraph (3) of this Article, shall be guilty of an offence and is liable upon conviction by a court to a fine not exceeding 250,000 afghanis or imprisonment for a term not exceeding two years or both.

Article 110 Additional income tax related to Tax Identification Numbers (1) A person required to have a Tax Identification Number under Article 91 of this Law who fails to apply for a Tax Identification Number without reasonable cause shall pay additional income tax of 5,000 afghanis if the person is a natural person or 20,000 afghanis if the person is a legal person.

(2) A person required to have a Tax Identification Number under Article 91 of this Law who fails to apply for a Tax Identification Number as a result of gross 
negligence shall pay additional income tax of 15,000 afghanis if the person is a natural person or 50,000 afghanis if the person is a legal person.

(3) A person required to have a Tax Identification Number under Article 91 of this Law who deliberately fails to apply for a Tax Identification Number shall pay additional income tax of 30,000 afghanis if the person is a natural person or 100,000 afghanis if the person is a legal person.

Article 111 Offenses committed by taxation officers

(1) A taxation officer who discloses confidential information with the intent of any direct or indirect benefit from the disclosure, or any person who assists a taxation officer to disclose confidential information, is guilty of an offence and is liable upon conviction by a court to a fine not exceeding 125,000 afghanis or imprisonment for a term of up to one year, or both.

(2) A taxation officer who misuses their position in any unauthorized way for the purpose of direct or indirect financial or other benefits is guilty of an offence and is liable upon conviction by a court to a fine not exceeding 225,000 afghanis or imprisonment for a term not exceeding three years, or both.

Article 112 Authority for collection of additional tax Additional tax imposed under the provisions of this Chapter will be collected by Ministry of Finance tax offices.

\section{CHAPTER XVII FINAL ARTICLES}

Article 113 Provision of forms and rulings

(1) The Ministry of Finance is required to

provide forms that are necessary for the purpose of determining and collecting

tax according to the Law.

(2) The Ministry of Finance may issue an income tax manual and separate public and private rulings regarding income tax for the better administration of the provisions of this Law.

Article 114 Non issuance of licenses

Where natural or legal persons have not paid

their tax due by the due date according to the provisions of this Law, the Ministry of Finance may officially inform those government agencies and departments which have the authority to issue licenses to not renew their licenses. The licenses of such persons may be issued only when they have such documents from the Ministry of Finance to indicate they have fulfilled their tax obligations and submitted them to the relevant office.

Article 115 Requirements for entitlement to exemption

(1) Approved enterprises which

have not met the requirements of the provisions of the Law on Domestic and

Foreign Private Investment in Afghanistan published in official gazette no (803) dated 1381/6/20 and other related laws are no longer entitled to income tax exemption under the provisions of that Law from 21 June 2004 (1 Saratan 1383).

(2) Approved enterprises according to the provisions of the Law on

Domestic and Foreign Private Investment in Afghanistan mentioned in paragraph (1) of this Article which have commenced business activities prior to 22 November 2003 (I Kawos 1382) may benefit from the income tax exemptions mentioned in the investment law only if they have complied with and continue to comply with the provisions of that law and other related laws. (3) If an approved enterprise granted tax exemption under the provisions of the Law on Domestic and Foreign Private Investment in Afghanistan holds 
capital assets on the date the exemption ends as a result of paragraph (1) of this Article or the date the tax exemption expires, the remaining undepreciated value of the capital assets on that date will be treated as the cost of those capital assets.

Article 116 Primacy of Income Tax Law

(1) In the event of any conflict between contracts, agreements, and provisions of other laws with the provisions of the Income Tax Law, the Income Tax Law shall prevail.

(2) International contracts and agreements entered into by the Islamic

Republic of Afghanistan with foreign countries or United Nations agencies are excluded from the provisions of the paragraph (1) of this Article.

Article 117 Enforcement date

This Law shall come into force from the date that it is signed and shall be published in the Official Gazette. After its enforcement, the Income Tax Law published in Official Gazette number 25 dated 29 Saor 1344 (1965), amendments mentioned in decree number (52) dated 27 Hoot 1383 (17 March 2005) and other amendments, attachments and provisions contrary to this Law are cancelled.

Note: The Income Tax Law was signed by the President on 14 November 2005 (23 Aqrab 1384) and the law commenced with effect from that date.

\section{Decree of President of Islamic Republic of Afghanistan \\ On the Enactment of Income Tax Law \\ No. 95 Date: 14 November 2005}

Article 1:

I endorse (sign) the Income Tax Law containing 17 chapters and 117 articles which has been approved by Ministerial Council.

\section{Article 2:}

The provisions set forth in the following articles of the Income Tax Law apply from the following dates:

1. Article 8 (5), article 13 (2 and 3), article 18 (2) 3, article 42 (2), and article 93 (5)

from 1 Hamal 1385 (21 March 2006)

2. Article 58 and 60 from 1 Mizan 1384 (23 September 2005)

3. Article 70 (1) and article 71(1) from 1 Hamal 1384 (21 March 2005)

\section{Article 3:}

This decree comes into effect from the date it is signed and shall be published in the Official Gazette with the Income Tax Law.

(signed)

Hamid Karzai

President of Islamic Republic of Afghanistan 


\section{CUSTOMS CODE}

UNOFFICIAL ENGLISH TRANSLATION. CHECK AGAINST DELIVER OF THE FINAL DARI VERSION KABUL MARCH 20, 2005

\section{CONTENTS}

CHAPTER 1:GENERAL PROVISIONS

ARTICLE 1 (CONSTITUTIONAL AUTHORITY)

ARTICLE 2 (RESPONSIBLE AUTHORITY)

ARTICLE 3 (DEFINITIONS)

ARTICLE 4 (UNIFORM APPLICATION OF CUSTOMS LAW)

ARTICLE 5 (THE CUSTOMS TERRITORY OF THE COUNTRY)

ARTICLE 6 (CUSTOMS AREAS)

ARTICLE 7 (SCOPE OF WORK OF CUSTOMS)

CHAPTER 2: CUSTOMS ADMINISTRATION

ARTICLE 8 (ORGANIZATION)

ARTICLE 9 (SERVICE UNIFORM AND CONDITIONS OF SERVICE)

ARTICLE 10 (MOVEMENT OF GOODS)

ARTICLE 11 (RESPONSIBILITIES OF CUSTOMS)

ARTICLE 12 (PROVIDING INFORMATION)

ARTICLE 13 (CONFIDENTIALITY)

ARTICLE 14 (CUSTOMS CONTROLS OUTSIDE OF CUSTOMS OFFICES)

ARTICLE 15 (RIGHTS AND OBLIGATIONS OF IMPORTERS AND EXPORTERS)

ARTICLE 16 (BROKERAGE)

ARTICLE 17 (TAKING OF DECISIONS)

ARTICLE 18 (REVIEW OF CUSTOMS DECISIONS)

CHAPTER 3: TAKING CARE OF AN OBJECTION

ARTICLE 19 (ARBITRATION)

ARTICLE 20 (OPINION)

ARTICLE 21 (THE FINALITY OF AN OPINION)

ARTICLE 22(METHOD OF EXECUTIONS)

CHAPTER 4: CUSTOMS TARIFF AND VALUATION OF GOODS

ARTICLE 23 (THE CUSTOMS TARIFF)

ARTICLE 24 (VALUATION OF GOODS)

ARTICLE 25 (EXCHANGE RATE)

ARTICLE 26 (PERISHABLE GOODS)

CHAPTER 5: FAVORABLE TARIFFS

ARTICLE 27 (CASES FOR GRANTING A FAVORABLE TARIFF)

ARTICLE 28 (REQUESTS FOR A FAVORABLE TARIFF)

CHAPTER 6: ORIGIN OF GOODS

ARTICLE 29 (PRODUCTION OF GOODS IN A COUNTRY)

ARTICLE 30 (PRODUCTION OF GOODS IN MORE THAN ONE COUNTRY)

ARTICLE 31 (CERTIFICATE OF ORIGIN)

ARTICLE 32 (PREFERENTIAL ORIGIN)

ARTICLE 33 (RETURN OF GOODS)

CHAPTER7: PRESENTATION OF GOODS TO CUSTOMS

ARTICLE 34 (ENTRY AND EXIT OF GOODS)

ARTICLE 35 (PLACE FOR PRESENTATION OF GOODS)

ARTICLE 36 (TRANSPORTATION OBSTACLES TO PRESENTATION OF GOODS) 
ARTICLE 37 (PRESENTATION OF AIR SHIPMENTS AT AIRPORT OF FINAL DESTINATION)

ARTICLE 38 (PRESENTING MANIFESTS TO CUSTOMS)

ARTICLE 39 (CUSTOMS SUPERVISION ON AIRCRAFT)

ARTICLE 40 (EXEMPTION FROM OBLIGATION TO PRESENT A MANIFEST)

ARTICLE 41 (AIRCRAFT'S FORCED LANDING

ARTICLE 42 (CUSTOMS DECLARATION FOR POSTAL GOODS)

ARTICLE 43 (EXEMPTION FROM DECLARATION)

ARTICLE 44 (EXPORT POSTAL SHIPMENTS)

ARTICLE 45 (CUSTOMS CONTROL ON TRANVELERS LUGGAGE)

ARTICLE 46 (PRESENTATION OF GOODS FROM THE DETERMINED LOCATION TO CUSTOMS)

ARTICLE 47 (GOODS VERIFICATION AND TAKING OF SAMPLES)

ARTICLE 48 (SUBMISSION OF A SUMMARY DECLARATION)

ARTICLE 49 (UNLOADING AND TRANSSHIPPING FROM DESIGNATED SITES)

CHAPTER 8: TEMPORARY STORAGE OF GOODS

ARTICLE 50 (PLACES OF TEMPORARY STORAGE

ARTICLE 51 (REMOVING GOODS FROM TEMPORARY STORAGE)

ARTICLE 52 (NON-ALLOWED GOODS)

CHAPTER 9: CUSTOMS DECLARARTION

ARTICLE 53 (ASSIGNING A DESIGNATION FOR NON-AFGHAN GOODS)

ARTICLE 54 (TIME PERIOD FOR COMPLETING CUSTOMS DECLARATION)

ARTICLE 55 (DECLARATION OF THE GOODS FOR A CUSTOMS PROCESS)

ARTICLE 56 (ACCEPTANCE OF THE DECLARATION)

ARTICLE 57 (VOLUNTARY AMENDMENT OR WITHDRAWAL OF DECLARATIONS)

ARTICLE 58 (VERIFICATION OF THE DECLARATION)

ARTICLE 59 (COMPOSITE DECLARATION)

ARTICLE 60 (PARTIAL CONTROL)

ARTICLE 61 (THE IDENTIFICATION OF THE GOODS)

ARTICLE 62 (RELEASE OF GOODS)

ARTICLE 63 (GOODS INELIGIBLE FOR RELEASE)

ARTICLE 64 (CUSTOMS AMENDMENT OR INVALIDATION OF DECLARATIONS)

CHAPTER 10: CUSTOMS PROCESSES

ARTICLE 65 (RELEASE OF GOODS FOR FREE CIRCULATION)

ARTICLE 66 (CONDITIONAL RELEASE OF GOODS)

ARTICLE 67 (CLASSIFICATION OF MIXED GOODS)

ARTICLE 68 (LOSS OF CUSTOMS STATUS AS AFGHAN GOODS)

ARTICLE 69 (CUSTOMS PROCESSES WITH ECONOMIC IMPACT)

ARTICLE 70 (CONDITIONS FOR GRANTING AN AUTHORIZATION)

ARTICLE 71 (SECURITY)

ARTICLE 72 (RELEASE FROM THE PROCESS)

ARTICLE 73 (TRANSFER OF THE RIGHTS AND OBLIGATIONS)

ARTICLE 74 (THE TIME FOR DETERMINING THE CUSTOMS DEBT)

ARTICLE 75 (TRANSIT PROCESS)

ARTICLE 76 (RELEASE FROM THE PROCESS)

ARTICLE 77 (TRANSIT VIA THIRD COUNTRIES)

ARTICLE 78 (TRANSIT SECURITY)

ARTICLE 79 (EXEMPTIONS FROM GIVING SECURITY)

ARTICLE 80 (OBLIGATION OF PERSONS RESPONSIBLE FOR TRANSIT GOODS)

ARTICLE 81 (CUSTOMS WAREHOUSING)

ARTICLE 82 (WAREHOUSE TYPES)

ARTICLE 83 (WAREHOUSE KEEPER AND HIS RESPONSIBILITIES)

ARTICLE 84 (APPROVAL FOR OPERATING A CUSTOMS WAREHOUSE)

ARTICLE 85 (TRANSFER OF RIGHTS AND RESPONSIBILITIES)

ARTICLE 86 (DISTINCTIVE CASES) 
ARTICLE 87 (TIME FOR DEPOSITS IN WAREHOUSE)

ARTICLE 88 (HANDLING OF GOODS UNDER CUSTOMS WAREHOUSING PROCESS)

ARTICLE 89 (TEMPORARY WITHDRAWALS FROM WAREHOUSE)

ARTICLE 90 (TRANSFER OF GOODS)

ARTICLE 91 (CUSTOMS VALUE OF WAREHOUSED GOODS)

ARTICLE 92 (INWARD PROCESSING)

ARTICLE 93 (INWARD PROCESSING OPERATIONS)

ARTICLE 94 (APPLICATION FOR APPROVAL OF INWARD PROCESSING

ARTICLE 95 (TIME PERIOD FOR EXPORTATION IN INWARD PROCESSING)

ARTICLE 96 (RATE OF YIELD OF INWARD PROCESSING)

ARTICLE 97 (RELEASE FOR FREE CIRCULATION FROM INWARD PROCESSING)

ARTICLE 98 (COMPENSATING PRODUCTS OF INWARD PROCESSING)

ARTICLE 99 (CUSTOMS DUTIES ON COMPENSATING PRODUCTS OF INWARD PROCESSING)

ARTICLE 100 (COMPENSATING PRODUCTS OF INWARD PROCESSING AFTER OUTWARD

PROCESSING)

ARTICLE 101 (DRAWBACK CASES)

ARTICLE 102 (DRAWBACK DECLARATION)

ARTICLE 103 (TEMPORARY EXPORTATIONS PURSUANT TO DRAWBACKS)

ARTICLE 104 (DRAWBACK REFUNDS)

ARTICLE 105 (PROCESS UNDER THE CUSTOMS CONTROL)

ARTICLE 106 (APPROVAL FOR PROCESSING UNDER CUSTOMS CONTROL)

ARTICLE 107 (APPROVAL CONTENTS FOR PROCESSING UNDER CUSTOMS CONTROL)

ARTICLE 108 (DEBT AMOUNT IF PROCESS IS NOT COMPLETED)

ARTICLE 109 (IMPORT OF COMPENSATING PRODUCTS OF PROCESSING UNDER CUTOMS

CONTROL)

ARTICLE 110 (THE TEMPORARY IMPORTATION PROCESS)

ARTICLE 111 (APPROVAL FOR TEMPORARY IMPORTATION)

ARTICLE 112 (CONDITIONS FOR APPROVAL FOR TEMPORARY IMPORTATION)

ARTICLE 113 (SPECIAL CONDITIONS IN TEMPORARY IMPORTATION PROCESS)

ARTICLE 114 (THE DUTY AMOUNT PAYABLE FOR GOODS UNDER THE TEMPORARY

IMPORTATION PROCESS WITH PARTIAL RELIEF)

ARTICLE 115 (CHANGE OF CUSTOMS DESIGNATION OF TEMPORARILY IMPORTED GOODS)

ARTICLE 116 (OUTWARD PROCESSING)

ARTICLE 117 (APPLICATION FOR THE APPROVAL OF OUTWARD PROCESSING)

ARTICLE 118 (CONTENTS OF OUTWARD PROCESSING APPROVAL)

ARTICLE 119 (IMPORT DUTY FOR COMPENSATING PRODUCTS OF THE OUTWARD

PROCESSING)

ARTICLE 120 (GOODS REPAIRED WITHOUT CHARGE IN THE OUTWARD PROCESSING)

ARTICLE 121 (TRANSFER OF RIGHTS OF THE OUTWARD PROCESSING APPROVAL)

ARTICLE 122 (EXPORT PROCESS FOR AFGHAN GOODS)

ARTICLE 123 (EXPORTATION OF NON-AFGHAN GOODS)

CHAPTER 11: FREE ZONES AND FREE WAREHOUSES

ARTICLE 124 (THE MEANING OF DUTY FREE ZONES)

ARTICLE 125 (FREE ZONES DESIGNATION)

ARTICLE 126 (CUSTOMS SUPERVISION IN FREE ZONES)

ARTICLE 127 (CONDITIONS FOR ENTRANCE AND EXIT OF GOODS)

ARTICLE 128 (CUSTOMS STATUS OF GOODS IN DUTY FREE ZONES)

ARTICLE 129 (TIME LIMITS)

ARTICLE 130 (AUTHORIZED ACTIVITIES)

ARTICLE 131 (APPROVED REGISTERS)

ARTICLE 132 (TARIFF ON CONSUMED AND MISSING GOODS)

ARTICLE 133 (ABANDONMRNT/DESTRUCTION OF GOODS IN FREE ZONES

CHAPTER 12:CUSTOMS DESIGNATIONS

ARTICLE 134 (DESTRUCTION OR ABANDONMENT) 
ARTICLE 135 (DESTRUCTION OF GOODS)

ARTICLE 136 (PROCEEDS FROM ABANDONED GOODS)

CHAPTER 13: CUSTOMS DEBT

ARTICLE 137 (FORM OF SECURITY)

ARTICLE 138 (THE LIMIT OF A SINGLE SECURITY FOR SEVERAL ACTIONS)

ARTICLE 139 (THE SECURITIES AMOUNT)

ARTICLE 140 (CASH DEPOSITS)

ARTICLE 141 (GUARANTOR)

ARTICLE 142 (OTHER KINDS OF SECURITY)

ARTICLE 143 (ADDITIONAL SECURITIES)

ARTICLE 144 (RELEASE OF SECURITY)

ARTICLE 145 (LAWFUL ACTIVITIES WHICH CAUSE CUSTOMS DEBT)

ARTICLE 146 (UNLAWFUL ACTIVITIES CAUSING A CUSTOMS DEBT)

ARTICLE 147 (CUSTOMS DEBT ON REMOVAL OF GOODS FROM SUPERVISION WITHOUT PERMISSION)

ARTICLE 148 (NON OCCURRENCE OF DEBT)

ARTICLE 149 (RESPOSIBILITY OF PARTNERSHIPS)

ARTICLE 150 (DATE OF DETERMINING CUSTOMS DEBT)

ARTICLE 151 (ENTRY OF DEBT INTO ACCOUNTS)

ARTICLE 152 (DIFFERENCES IN ACCOUNT ENTRIES)

ARTICLE 153 (NOTIFICATION ABOUT DEBT ENTRY)

ARTICLE 154 (SITUATIONS FOR SETTLING AND EXTINQUISHING OF CUSTOMS DEBTS)

ARTICLE 155 (PAYMENT TERM FOR CUSTOMS DEBT)

ARTICLE 156 (DEFERRAL OF DEBT PAYMENT)

ARTICLE 157 (MANNER OF PAYMENT)

ARTICLE 158 (NON PAYMENT OF DEBT WITHIN THE PRESCRIBED TERM)

ARTICLE 159 (REFUND OR REMISSION OF AN ERRONEOUS ENTRY)

ARTICLE 160 (REMISSION OR REFUND FOR DEFECTIVE GOODS)

ARTICLE 161 (LIMIT OF THE AMOUNTS TO BE REFUNDED)

ARTICLE 162 (INTEREST ON REFUNDS)

ARTICLE 163 (ERRONEOUS REFUNDS)

CHATER 14: CUSTOMS VIOLATIONS AND PENALTIES

ARTICLE 164 (CUSTOMS POLICE ADMINISTRATION)

ARTICLE 165 (CUSTOMS VIOLATIONS)

ARTICLE 166 (ADMINISTRATIVE VIOLATIONS AND SANCTIONS)

ARTICLE 167 (PENALTIES)

ARTICLE 168 (MULTIPLE OFFENSES)

ARTICLE 169 ( METHOD FOR COLLECTION OF FINES)

ARTICLE 170 (DISCRETIONARY ADMINISTRATIVE PENALTIES)

ARTICLE 171 (LICENSE REVOCATION)

ARTICLE 172 (SMUGGLING OF GOODS)

ARTICLE 173 (SANCTIONS APPLICABLE TO SMUGGLING)

ARTICLE 174 ( SMUGGLING OBJECTS)

ARTICLE 175 (VEHICLES)

ARTICLE 176 (THE SEIZURE OF SMUGGLING OBJECTS)

ARTICLE 177 (PERISHABLE GOODS; LIVESTOCK

ARTICLE 178 (COMPENSATION FOR DAMAGES)

ARTICLE 179 ( RANGE OF PENALTIES)

ARTICLE 180 (AGGRAVATING CIRCUMSTANCES)

ARTICLE 181 (PATICIPATION OF GOVERNMENT EMPLOYEES IN SMUGGLING ACTIVITY)

ARTICLE 182 (EVALUATION OF ADMINISTRATIVE VIOLATIONS)

ARTICLE 183 (AUTHORITY FOR ACCESS TO INFORMATION)

ARTICLE 184 (REPORT AND COLLECTION OF EVIDENCE)

ARTICLE 185 (FILE ADMINISTRATION) 
CHAPTER 15: DISTRIBUTION OF REVENUES AND GRANTING INCENETIVES

ARTICLE 188 (INCENTIVES FOR INFORMANTS)

ARTICLE 189 (INCENTIVES FOR THE SEIZING PERSONS)

ARTICLE 190 (HALVED INCENTIVES)

CHAPTER 16: MISCELLANEOUS

ARTICLE 192 (PRESENTATION OF ANNUAL CUSTOMS REPORT)

ARTICLE 193

ARTICLE 194 (DATE OF ENFORCEMENT)

\section{CHAPTER 1 \\ GENERAL PROVISIONS}

\section{Article 1 (Constitutional Authority)}

This law has been enacted pursuant to Article 42 of the Constitution in order to ensure the collection of state revenues by the national customs authorities; to provide for the organization of customs; to define the scope of authority of customs officials; to provide for the supervision and the control of the movement of goods in and out of Afghanistan, and for the prevention of customs violations.

\section{Article 2 (Responsible Authority)}

The Ministry of Finance is responsible for the collection of customs revenues of the state, and for enforcing the provisions of this law and any other relevant customs legislation .

\section{Article 3 (Definitions)}

For the purposes of this law, the following definitions shall apply:

1- 'Person' means:

- a natural person; or

- a legal person,

2- "Persons established in Afghanistan" means:

- In the case of a natural person, any person who is

resident in the Afghanistan for more than 183 days per

year.

- A legal person who has a registered or a permanent

business office in Afghanistan.

3- "Customs" means the state agency which carries out and controls custom affairs of import, export, and transit goods, travelers and responsible person's baggage and parcel post in accordance with customs legislation.

4- Customs legislation" means this Law, and any other enforced legislation, international conventions and treaties containing customs provisions to which Afghanistan is a party and relevant rules and procedures.

5- "Customs Areas" means the areas where the customs authorities exercise their activities as well as areas where the customs authorities exercise direct and indirect control or supervision of the relevant affairs.

6- 'Customs decision' (tasmim) means any official order (hedayat e rasmi) by customs authorities pertaining to the application of Customs legislation to a particular case which affects one or more specific or identifiable persons. 7- 'Customs opinion' means the decision of the Customs 
Arbitration Admninistration (Edaara Hakamiyet e

Gumruki) taken with regard to a disputed customs case.

8- 'Customs status' means the categorization of goods as Afghan or non-Afghan goods.

9- 'Afghan goods' means goods:

- Wholly obtained or produced in the customs territory of the State in accordance with the provisions of Article

29;

- imported from other countries, which have been released for free circulation in the customs territory of the State;

- Obtained or produced in the customs territory of the

State, either from goods referred to in subparagraph (2)

alone, or from goods referred to both in subparagraphs

(1) and (2) above.

10- 'Non-Afghan goods' means goods other than those referred to in subparagraph 9 of this Article.

11- 'Customs debt' means a payment obligatory on a person, on account of customs duty, charges (haq ul zamat), dues (awarez), penalties (jerima), and any other monetary obligations (eltezamat e puli) that apply to specific goods or actions under customs legislation.

12- 'Customs Debtor' means any person liable for the payment of a customs debt.

13- "Responsible Person" is the declarant, except when the [this] Law indicates otherwise.

14- 'Import duty' means customs duty on the importation of goods.

15- 'Export duty' means customs duty on the exportation of goods.

16- 'customs supervision' means the inspection done by those authorities with a view to ensuring that customs legislation and, other provisions applicable to goods subject to customs supervision are observed, and may include measures for exercising customs control, when necessary. 17- 'customs control' means executing specific actions, such as examining goods, verifying the existence and the authenticity of customs documents, examining the accounts and other records inspecting means of transport, luggage and other goods carried by or on persons, seizing goods, and reporting suspects to the judicial and justice authorities, with a view to ensuring that customs legislation and, where appropriate, other provisions applicable to goods subject to customs supervision are respected in the customs territory of the State.

18- "Customs designation" means :

- the placing of goods under a customs process,

- their entry into a free zone, free warehouse, or duty free

shop.

- their destruction, or

- Their abandonment and transfer to the State.

19- 'Customs process' means the following stages (marahel):

- release for free circulation within the customs territory of

the State;

- conditional release of goods under customs supervision

- transit;

- customs warehousing; 
- inward processing;

- processing under customs control;

- temporary importation;

- outward processing;

- Exportation.

20- 'Suspensive process' means the following customs

processes which entails suspension of the payment of the

customs debt:

- transit;

- customs warehousing;

- inward processing

- processing under customs control;

- temporary importation;

21- "Suspensive goods" means goods placed under one or more of the suspensive processes mentioned in section 20 of this article. .

22- "Favorable tariff" means a reduction in, suspension of, or exemption from the otherwise applicable import duty stated in the Customs Tariff,

23- "Customs declaration" means the act or document whereby a person expresses, the wish to place goods under a given customs designation or process.

24- "Time of acceptance of the declaration" means the time when the customs declaration presented to customs authorities is accepted by the relevant [customs] office. 25- "Declarant" means any person who prepares and presents a customs declaration.

26- "Presentation of goods at customs" means the notification to the customs authorities, in accordance with the relevant procedures, of the arrival of goods at customs or at any other place designated or approved by the Customs authorities.

27- "Release of goods" means the act whereby the customs authorities make goods available to the declarant for placement or disposition under a customs designation or process.

28- "Holder of authorization" means the person to whom an authorization has been granted.

29- "Customs duty" means an amount of money assessed on imports or exports in accordance with the classification and rates stated in the Customs tariff, 30- "Force majeure" means a natural disaster, war, unexpected political and economic upheavals, or similar act beyond the control of the person affected.

31- "Commercial policy measures" means the imposition of quotas, ceilings, countervailing duties on subsidized foreign goods, anti-dumping duties, or similar provisions for advancing national (keshwar) commercial interests. 32- "Remission" (lit. "Cession"-Wogozari) means a decision to waive all or part of a customs debt prior to entry or after entry and before payment in accordance with article 151. 33- "Refund" means the repayment of part or all of a customs debt that has already been collected.

\section{Article 4 (Uniform Application of Customs law)}

(1) Customs legislation shall apply uniformly throughout the 
customs territory of the state.

(2) Customs legislation may also apply in other countries, within the framework of either international conventions or other provisions governing specific customs activities provided that they do not conflict with the laws of another country.

(3) Customs legislation may be applied in cooperation with customs administration of other countries at joint facilities, either inside or outside of Afghanistan's customs territory, in accordance with international agreements and conventions.

Article 5 (The Customs Territory of the State) The Customs Territory of the State shall include the land, and water territory, and the airspace of Afghanistan.

\section{Article 6 (Customs Areas).}

(1) Customs areas are established at border crossing points, international airports, duty free zones, customs warehouses and any other points within the Customs Territory as provided for in this Law.

(2) Customs areas may be established, altered or abolished upon the recommendation of the Customs

Administration and the approval of the Ministry of Finance.

\section{Article 7 (Scope of Customs Work)}

in order to secure (taamin) the interests of the State, Customs shall apply the necessary controls in accordance with customs legislation with respect to international shipments and import and export and movement of goods in the customs territory of the state.

CHAPTER 2

\section{CUSTOMS ADMINISTRATION}

\section{Article 8 (Organization)}

(1) Customs comprises the General Directorate, the Regional Directorates and their branches. All Customs shall work subordinate to and under the supervision of the General Directorate of Customs of the Ministry of Finance.

(2) The General Director of Customs is appointed upon the recommendation of the Minister of Finance in accordance with law.

(3) The Deputy Directors General of Customs are appointed, upon the proposal of the General Director of Customs, and confirmation of the Ministry of Finance, in accordance with the law.

(4) The other Civil Service (momorin) and auxiliary (ajir) personnel of the Customs are employed in accordance with the procedures established by the law.

Article 9 (Service Uniforms and Conditions of Service) (1) Customs personnel shall wear the service uniform. In the event that service needs make it necessary to work 
without wearing a uniform, the customs personnel must show their Identity Cards.

(2) Customs officers are not allowed to accept directly or indirectly, rewards in cash or kind for the customs services performed.

(3) Customs officers are not allowed to carry on any kind of business, or advising activity, that is incompatible with the faithful performance of customs duties.

\section{Article 10 (Movement of Goods)}

Goods may cross the State border, and designated customs borders at customs warehouses, at duty free zones, in airports, and at any other facilities under customs control, only at customs areas staffed by customs officials.

\section{Article 11 (Responsibilities of Customs)}

(1) Loading, unloading, movement, and transshipment of goods through specified customs borders [lines] as well as their release from a customs process, is carried out with the permission of Customs in accordance with Customs legislation.

(2) Customs is responsible for:

1.determining the value of goods and collecting the related customs debt.

2. Supervising, detecting, reporting and preventing smuggling;

3. detecting and evaluating violations of this law; 4. participating in preparing and signing international agreements and conventions in customs matters, in accordance with customs legislation;

5. preparing, collecting and, upon agreement of the Minister of Finance, distributing foreign trade statistical data to the Ministry of Commerce and other public institutions;

6. supervising customs goods, throughout the entire customs territory of the state;

7. exercising customs control over customs areas,

8. maintaining customs records

9. carrying out all other activities determined in customs legislation.

(3) In order to improve the enforcement of customs legislation, Customs, with the approval of the Minister of Finance may, subject to Article 13, sign agreements with state or non-state domestic or foreign, organizations, for exchanging information.

(4) Customs shall establish customs verification teams to verify the conformity of the quantity and quality of the goods transported with the customs documents accompanying them at exit from border crossing points and in airports, as well as at the exit of the inland customs offices, and at the facility of importers. If the goods and transportation are in conformity with the customs documents, the customs verification team will confirm the customs documents and stamp them. If the goods and transportation are not in conformity with the customs documents, they will draw up the appropriate 
written report, and submit it to the relevant customs office for investigation.

(5) Customs administrations shall assign mobile customs verification teams to verify customs compliance of transporters in the customs territory along roads. The members of the mobile teams shall examine the customs documents and the good upon presentation of their identity card and shall draw up the appropriate written report, to the relevant customs administration in accordance with the relevant procedures.

(6) In cases of danger to health, or to the environment, Customs may, upon notice to the declarant have goods presented to Customs destroyed or removed from the area in accordance with relevant procedures.

(7) When Customs receive information from other public authorities working in the customs territory of the state with regard to violations of customs legislation, Customs shall submit a written report, to the relevant customs administration for further investigation (rasidigi).

(8) When police authorities check vehicles that have been sealed by Customs, the vehicle shall be transferred to the nearest customs office to obtain the agreement of Customs for removal of the seal and to perform controls (bazrasi). In this case, the police and customs will submit a written report to Customs for investigation.

\section{Article 12 (Providing information)}

(1) Customs authorities may provide information free of charge to requesting parties concerning the application of customs legislation in the forms prepared by the Ministry of Finance, except when it pertains to an ongoing import or export operation or would be inconsistent with the secrecy provisions of Article 13.

(2) Incase the provision of information shall involve expense, customs authorities may collect the expenses from the applicant.

(3) The Ministry of Finance may in prepared forms, when needed require the necessary information to be supplied by relevant persons.

(4) Information provided by persons as required in section 3 is effective when signed.

\section{Article 13 (Confidentiality)}

The following information provided to Customs is covered by the obligation of professional secrecy and Customs will not disclose such information without permission of the person concerned and with legal authority to do so:

1 - The valuation of a specific goods,

2- Details [e.g. names and addresses] of suppliers of goods,

3- The results of testing, and

4- Other information which is provided to Customs on a confidential basis.

Article 14 (Customs Controls Outside of Customs Offices)

Customs, when the needs of the trade so require and upon request of the person concerned, may allow customs controls to be 
carried out at the premises pertinent to the importer. The Director of Customs for the area, taking into account the conditions, shall establish the cost of this service and collect them from the responsible person.

Article 15 (Rights and Obligations of Importers and Exporters)

(1) Importers and exporters of goods shall execute the customs clearance of the relevant import and export of goods by a customs broker licensed by the Ministry of Finance. (2) The provisions of paragraph 1 do not apply to Postal goods and goods imported by travelers pursuant to Articles 42 and 45 of this law.

\section{Article 16 (Brokerage)}

(1) Brokerage is a non-governmental business which persons may carry out upon obtaining a license from the Ministry of Finance

(2) The conditions for obtaining the license and the rights and obligations of the customs broker shall be regulated by separate rules (loyaha) approved by the Ministry of Finance.

\section{Article 17 (Taking of Decisions)}

(1) Customs may make a decision with regard to a particular customs transaction in accordance with customs legislation upon the request of the person concerned. The applicant must furnish and complete information and documents required by customs to make the decision. (2) Customs are obliged to take the decision mentioned in Section 1 within a maximum of 30 days and announce it to the applicant.

(3) In case the customs decision mentioned in section 2 is detrimental to the interests of the applicant or any other [interested] party, Customs shall notify their decision in writing together with the reasons to the applicant and shall explain that the applicant has the right to object.

\section{Article 18 (Review of Customs Decisions)}

(1) A customs decision may be reviewed upon submission of an application by the applicant. In case a decision was due to the submission of incorrect information by the applicant, review will not be permitted except in accordance with Article 186.

(2) Customs decisions mentioned in paragraph 1 shall be enforceable and the customs debt assessed (other than penalties paid in accordance with Article 186) shall be collected and shall remain in trust (taht amanat) until final decision

(3) An interested party may request a review of a disputed customs decision through any competent regional customs authority to the General Directorate of Customs, within 10 days from the day of notification of the decision by Customs. The General Directorate of Customs must issue a decision within 20 days on the outcome of the review. In the event the General Director of Customs does not issue a decision within this time 
period, the request shall be presumed to have been decided in favor of the person making it.

(4) In case of an objection to a decision made by the General Directorate of Customs or the rejection of the request by the General Directorate of customs, it may be submitted to the Customs Arbitration Administration.

(5) An objection to a customs decision shall be made by filing a notice of objection mentioned in paragraph 4 and it shall be presented to the Customs Arbitration Administration within fifteen days of receiving a customs decision from the General Directorate of Customs, along with security for costs in the amount of 2 percent of the contested amount.

\section{CHAPTER 3}

\section{TAKING CARE OF AN OBJECTION}

\section{Article 19 (Arbitration)}

(1) The Customs Arbitration Administration will be established within the framework of the Ministry of Finance for the purpose of taking care of objections to the decisions of Customs.

(2) The Arbitration Administration shall be composed of three members to be appointed upon proposal of the Minister of Finance by the Head of State.

\section{Article 20 (Customs Opinion)}

(1) The opinion of the Customs Arbitration Administration shall be final and enforceable where the amount of customs debt in dispute is up to 50000 Afghani.

(2) If the amount of the customs debt in dispute is greater than Afghani 50,000 the parties may in cases when dissatisfied refer the opinion to the relevant commercial Court. The order of court shall be final and enforceable.

\section{Article 21( Finality of an opinion)}

Administrative fines for smuggling agreed by the parties (tarazi tarfin) pursuant to Article 170 shall, in accordance with the relevant procedure, be submitted to the Customs Arbitration Administration which shall determine solely whether the settlement is consistent with Article 170.

\section{Article 22(Method of Executions)}

The manner of taking care of the objections sent to the Customs Arbitration Administration shall be regulated in a separate regulation.

\section{CHAPTER 4 \\ CUSTOMS TARIFF AND VALUATION OF GOODS}

\section{Article 23 (The Customs Tariff)}

(1) The customs tariff is a document enacted in accordance with this law which determines the import and export duty of goods based on their classification.

(2) The Customs Tariff shall be approved by the Minister of Finance upon the recommendation of the General 
Director of Customs.

(3) No treaty, international agreement, law (other than this law), regulation or other legislative document shall affect the Customs Tariff, unless the change is implemented through an amendment or annex to the Tariff.

(4) The General Directorate of Customs is responsible for carrying out the tariff classification of goods concerning description and coding in accordance with the Harmonized System of the World Customs Organization and for assessing any corresponding duty under the Customs Tariff.

\section{Article 24 (Valuation of Goods)}

(1) The customs value of goods for the purpose of collecting customs debts shall be determined by relevant customs authorities in accordance with a separate regulation to this law.

(2) In order to combat false valuation of certain goods with suspicious values, their minimum value shall be determined by General Directorate of Customs in accordance with the relevant procedures.

(3)A list of the goods mentioned above and specific values assigned to them shall be published.

\section{Article 25 (Exchange Rate)}

(1) The value of goods according to customs legislation shall be computed in Afghan currency.

When the value of goods is expressed in foreign currency and there is need to determine customs value, the value of goods shall be determined in accordance with the Da Afghanistan Bank exchange rate.

(2) The exchange rate shall be the rate announced by The Afghanistan Bank on the last working day of the month and shall be valid for a period starting from the 6th day of every month and ending on the 6th day of the following month.

(3) Whenever the exchange rate published by the $\mathrm{Da}$ Afghanistan Bank differs by $5 \%$ or more from the rate announced in accordance with paragraph (2) of this article, a new rate will be provided and it shall be effective from the second working day following its announcement and notification to Customs as the rate effective for the rest of that period.

\section{Article 26 (Perishable Goods)}

The customs value for perishable goods, at the request of the declarant, shall be determined by the Director of Customs of the area [mahal] in accordance with customs legislation, without applying the valuation criteria established for other goods

\section{CHAPTER 5 FAVOURABLE TARIFF}

Article 27 (Cases for Granting Favourable Tarrifs)

(1) A favorable tariff shall be granted as provided in 
customs legislation in accordance with Article 23(3), and in the cases referred to in paragraph 2 .

(2) The following imported goods shall be exempted from paying customs duty:

1- Goods imported by officials of the State during official travels not in excess of Afghani 100,000 as provided by the Customs Tariff.

2- Office materials and equipment of political representatives and international agencies, intended to be used in residences and offices of representatives of foreign countries in Afghanistan, after confirmation of permission to do so by competent authorities.

3- Items intended for personal use by foreigners working in Afghanistan according to the terms and conditions of their contract.

4- Permitted books, gazettes, magazines and newspapers. 5- Goods provided for government projects funded by loans or imported into the country by or for public and private foreign and International relief and development agencies approved by the government.

6- Personal effects used by Afghan delegations or Afghan international workers and their family members while abroad.

7- Travelers' personal goods in accordance with the Customs Tariff.

8- Commercial samples and advertising gifts.

9- Post parcels valued at Afghani 5000 or less.

10- honorary decorations or awards;

11- samples sent to organizations protecting

copyrights or industrial or commercial patent rights;

12- Used movable property belonging to natural persons, who transfers their normal place of residence from another country to the State, as provided in the Customs Tariff;

13- a consignment of less than Afghani 1000 value;

14- Pure-bred breeding animals and insects and laboratory animals; biological or chemical substances needed for scientific researches;

15- therapeutic substances of human origin and blood grouping and tissue typing reagents,;

16- substances for the quality control of medicinal products;

17- Fuels, lubricants and equipments carried with and necessary for the normal functioning of transport vehicles in accordance with the relevant procedure. 18- Other goods may be included as exempted goods upon recommendation of Minister of Finance and approval of Council of Ministers as required.

\section{Article 28 (Request for a Favourable Tariff)}

(1) To obtain the benefits of a favorable tariff a declarant may present a request before or after completion of the customs process.

(2) If a favorable tariff is restricted to a certain volume of imports, it ceases to be valid in the following conditions: 1- quotas, when the stipulated limit on the volume of 
imports is reached;

2- Tariff ceilings, according to specific provisions in the law.

(3) The manner, and the conditions on which a favorable tariff is granted, any quantitative or value-based limits on imported goods or benefits based on their origin, nature, or end-use, shall be determined in a separate procedure.

\section{CHAPTER 6 ORIGIN OF GOODS}

Article 29 (Production of Goods in a Country)

(1) When goods are wholly originated or produced in a country, that country shall be known as the origin of those goods. Such goods includes:

1- mineral products extracted within that country;

2- vegetable products harvested therein;

3- live animals born and raised therein;

4- products derived from animals raised therein;

5- products of hunting or fishing carried on therein; 6- products of sea fishing and other products taken from the sea outside a country's territorial waters by vessels flying the flag of that country and registered or recorded therein;

7- goods obtained or produced from the products referred to in subparagraph (6) on board factory ships which fly the flag of that country and are registered or recorded therein;

8- products taken from the seabed or subsoil beneath the seabed outside the territorial waters provided that the country has exclusive rights to exploit that seabed or subsoil;

9- waste and scrap products derived from manufacturing operations and from used articles, provided that they were collected therein and are fit only for the recovery of raw materials;

(2) Goods, which are obtained or produced wholly from goods referred to in paragraph (1), or their derivatives at any stage of production.

Article 30 (Production of Goods in More than one Country)

Goods whose production involves more than one country shall

be deemed to originate from the country where they

underwent their last substantial processing [transformation].

\section{Article 31(Certificate of Origin)}

(1) The manner of Certification of a document proving the origin of goods shall be arranged in accordance with separate procedures.

(2) Certification of documents proving the origin of goods may be issued by the responsible authorities for the region in which the goods were produced.

(3) in case the custom authorities have doubt with regard to a certificate of origin, such authorities may require additional proofs ensuring that the documents of origin comply with customs legislation. 
(4) The procedure referred to in paragraph (1) of this article shall provide the conditions under which a country is considered as the origin of goods which shall be applied in the following cases:

1- to implement the Customs Tariff, excluding the measures referred to in Article 23(2) of this law; and

2- To implement State measures restricting trade in particular goods.

\section{Article 32 (Preferential Origin)}

The preferential conditions for determination of the origin of goods for purposes of taking advantage measures contained in international agreements, as well as the method of issuing certificates of preferential origin, shall be arranged in a separate procedure.

\section{Article 33(Return of Goods)}

(1) Afghan or non-Afghan goods that have been released for free circulation in the State, which, after having been exported there from, are then brought back into the customs territory of the State are referred to as "returned goods." Returned goods which have been processed outside of Afghanistan shall be subject to the conditions of the process of outward processing.

(2) Goods which within three years of export are returned to the customs territory of the State for purposes of release for free circulation, shall at the request of the person concerned be exempt from import duty. The General Directorate of Customs may extend this period in light of special circumstances;

(3) When, prior to their exportation from the customs territory of the State, the returned goods had been released for free circulation at a favorable tariff because of their use for a particular purpose, exemption from duty under paragraph 1 shall be granted only if they are to be re-imported for the same purpose.

(4) Any import duty paid on goods when they were first released for free circulation shall be credited against the amount of import duty chargeable when the same goods are returned.

\section{CHAPTER 7 PRESENTATION OF GOODS AT CUSTOMS}

\section{Article 34 (Entry and Exit of Goods)}

(1) The time of entry or exit is considered to take place when goods, cross the State border to enter or leave the customs territory of the State.

(2) The driver of a commercial means of transport entering or leaving the customs territory of the State, must submit to the customs a manifest of the goods carried on the means of transport before:

1- the captain of an aircraft or vessel, when the goods can be removed from the aircraft or vessel; or

2- any other means of transport, when the vehicle enters into the customs territory of the State. 
(3) A Manifest of Goods need not contain details about the goods of travelers who are themselves required to make a declaration under Article 45.

(4) A "Manifest of Goods" shall contain information regarding the nationality, flag, and crew of the means of transport, as well as all the information necessary for the identification of the cargo, as provided for in a separate procedure.

(5) Goods brought into the customs territory of the State shall, at the time of their entry, be subject to customs supervision and control by the customs. Such goods shall not be moved without the permission of the customs.

(6) Goods shall remain under customs control and supervision until determination of their final customs designation.

\section{Article 35 (Place for Presentation of Goods)}

The General Directorate of Customs shall specify a place for Presentation of goods and their transfer to customs. The time for completing any transfer of imported goods from the border customs sites to the approved place, and the routes permitted therefore, shall be provided in a separate procedures.

Article 36 (Transportation Obstacles to Presentation of Goods)

(1) When, by reason of unforeseeable circumstances or force

majeure, the owner of goods can not transfer the goods

to the location specified in Article 35, the owner of goods shall be obliged to inform the customs authority of the situation. Where the unforeseeable circumstances or force majeure do not result in total loss of the goods, such person is also obliged to inform the Customs of the precise location of the goods.

(2) When by reason of unforeseeable circumstances or force majeure, an aircraft is forced to enter or land temporarily in the customs territory of the State, the captain of his representative, shall be obliged to report the situation immediately to Customs.

(3) Customs shall be obliged to take the measures necessary to enable the customs supervision of goods mentioned in this Article, ensuring that they are subsequently conveyed to a customs office or other designated places .

\section{Article 37 (Presentation of Air Shipments at the Airport of Final Destination)}

(1) When goods are brought into the customs territory of the State from another country by air, and are consigned under cover of a single transport document by the same mode of transport to another airport in Afghanistan, they shall be presented at customs, without delay, at the airport where they are unloaded.

(2) Specific provisions regarding customs control, supervision and other customs executions at the time of entry and exit for goods from the customs territory of the State are laid down in a separate procedure. 
Article 38 (Presenting Manifests to Customs)

(1) Aircrafts carrying imported or exported goods fly in air corridors (dahlez hawai) designated, in accordance with the Law of Civil Aviation, and must land and take off only from international airports approved for international flights.

(2) The captain of an aircraft carrying goods and destined to leave Afghanistan, must present customs officer the customs declaration or manifest of goods on board to be exported from the customs territory of the State.

Customs must verify that the goods so indicated in the manifest of declaration correspond to those on board the aircraft.

Article 39(Customs Supervision on Aircraft ) (1) Aircraft, flight crew and cabin crew, travelers, crew luggage, traveler baggage, and transported goods, except as provided in Article 37(1), are subject to customs supervision at the first airport of arrival in Afghanistan. (2) An airport authorized for international traffic in accordance with Civil Aviation Law, is subject to customs supervision.

(3) The Captain of an aircraft must, as soon as the aircraft lands at an authorized airport, submit to the customs office a manifest of all goods carried on the aircraft, except for goods mentioned in Article 34(3).

(4) The provisions of paragraphs (1), (2) and (3) of this article, shall also be applicable whenever an aircraft is departing to a destination outside the country.

Article 40 (Exemption from Obligations to Present a Manifest)

The following shall not present a manifest to the customs :

1- aircraft flying from one airport to another in

Afghanistan unless they have any stops at an airport outside Afghanistan or transport goods subject to the customs control and supervision;

2- private aircraft for personal use which is not carrying goods subject to customs control and supervision

Article 41 (Aircraft's Forced Landing)

If, in cases of emergency or force majeure, an aircraft has to land at an airport not authorized for receiving international air traffic, the captain of the aircraft must, immediately after landing and stopping, inform the nearest customs authority, which shall place the aircraft, cabin, flight crew, travelers and goods under customs supervision.

Article 42 (Customs Declaration for Postal Goods)

(1) All postal goods containing consignments for commercial purposes as well as postal goods containing consignments of an aggregate value, for each consignment exceeding the threshold value of Afghanis 5000 , or other value as may be provided in the relevant procedures, are subject to a customs declaration. 
(2) Postal goods shall be accepted and delivered between a foreign post office and the State's Post office under customs supervision. In case of regular consignments by small package freight shippers, the General Directorate of Customs may authorize immediate release of goods under a security and subsequent submission of an appropriate declaration covering, all goods imported within a fixed period of time as provided by the Procedure.

(3) Postal shipments shall remain under customs supervision while customs requirements are completed in the post office. The Postal and Parcel Directorate of Customs shall designate post offices where the customs requirements may be completed.

\section{Article 43 (Exemption from Declaration)}

The following postal consignments do not require a declaration:

1- postcards and letters containing personal messages only; 2- printed matters not liable for import duty;

3- all other consignments sent by letter or parcel post, which have no commercial value.

\section{Article 44 (Export Postal Shipments)}

Pursuant to export provisions of this Law and international regulations, the Directorate of Customs may prescribe restrictions and special conditions on postal shipments sent abroad.

Article 45 (Customs Control of Tranvelers Luggage)

(1) When entering or leaving Afghanistan, travelers are obliged to declare goods in their possession to Customs , and show them upon request.

(2) Customs authority may inspect the goods for the purpose of verifying the declaration referred to in paragraph 1 with the goods.

(3) Goods carried by diplomatic couriers, and certified in writing by their relevant agencies shall not be subject to the provisions of Articles 42 to 44 .

Article 46 ( Presentation of Goods at the Determined Location to Customs) Goods which arrive at the place for Presentation of goods at customs shall be presented, without delay, except for delay due to no fault of the person presenting the goods. Any person who makes a presentation of goods at customs shall provide within the time limit prescribed any required declaration, documents, or information, and shall provide all necessary assistance as may be requested by the customs.

\section{Article 47 (Goods Verification and Taking of Samples)}

(1) During presentation of goods at customs, an officer of the Customs may take a sample of the goods, to assign them a tariff classification, or customs designation. The taking of samples may also be made at the request of the owner of goods or his agent.

(2) The importer, exporter or their agent shall be entitled to 
be present when samples are taken, and are obliged to be present when instructed by customs authority;

(3) The sample shall be examined in a place designated and

during the hours prescribed by the General Directorate of

Customs; where the samples are not destroyed during the

examination, they will be returned to the owner or his

agent, otherwise the Customs shall not be liable for the payment of compensation.

(4) The owner or agent responsible for the goods shall be responsible to pay the cost of transferring to the examination sites, unpacking, weighing, repacking and any other operation involved in the sampling and exanimation process.

Article 48 (Submission of a Summary Declaration)

(1) The owner of goods or his agent shall submit a summary declaration within one hour after the presentation of goods at customs in accordance with the relevant procedure. The customs may allow an additional period for submitting the declaration, until the first working day following the day of presentation of goods at customs. (2) Customs shall be obliged to retain the summary declaration. Goods entered in the summary declaration will be placed in temporary storage pending the presentation of a completed declaration.

(3) If a completed customs declaration has been submitted prior to the expiry of the period referred to in paragraph I of this Article, the owner of the goods or his representative shall not be obliged to submit a summary declaration.

(4) The owner of the goods or his representative and travelers shall not be required to file a summary declaration for goods described in Article 42.2 of this law, unless this would jeopardize customs supervision of the goods.

Article 49 (Unloading and Tansshipping at Designated Sites)

(1) Goods shall be unloaded or transshipped from the means of transport carrying them at designated places with the permission of Customs, except where there is imminent danger necessitating the immediate unloading of all or part of the goods. In the latter case, the owner of goods or his agent shall immediately inform Customs.

(2) Customs may at any time require goods to be unloaded and unpacked in order to inspect the goods and their means of transport. The person who introduced the goods or his agent shall be entitled to be present while the goods are examined.

(3) Customs are obliged to notify their intention to proceed with the examination to the person responsible or his agent. If within two hours there is no reply, Customs may proceed with the examination of goods in their absence. 


\section{TEMPORARY STORAGE OF GOODS}

Article 50 (Places of Temporary Storage

(1) From the moment of acceptance of the summary declaration and until the time of acceptance of the customs declaration referred to in Article 55 of this Law, such goods shall be considered as "goods in temporary storage". Goods in temporary storage shall be stored in customs areas or any other place determined by Customs (2) Good referred to in paragraph (1) shall not be subject to any form of handling. The provisions of article 47 of this law and such forms of handling as are designed to ensure their preservation in the original state ( without modifying their appearance or technical characteristics) shall be an exception to this rule.

(3) The customs authorities may require the owner of the goods or his agent to provide security with a view to ensuring payment of any customs debt and fulfillment of his obligations provided for by this law

Article 51 (Removing Goods from Temporary Storage) (1) If the summary declaration is not submitted within the periods determined in accordance with Article 48, the Director General of Customs shall, taking into account Article 54(3), without delay take all measures necessary, including, after providing notice to person responsible for goods, for the purpose of sale of, or assigning a customs designation for, the goods left at customs, in accordance with the relevant procedure.

(2) Customs may, at the expense of the owner of the goods, transfer the goods mentioned in paragraph 1 to a place which is under customs supervision, and keep them there until a determination is made concerning the sale or customs designation of the goods.

\section{Article 52 (Non-allowed Goods )}

(1) Customs authorities who believe that the goods are smuggled according to the provisions of this law shall upon final decision by a responsible authority, take measures for sale or other authorized action with respect to the goods.

(2) Goods that are prohibited in accordance with 53(2) shall be seized by customs authorities, and treated in accordance with Paragraph. 1

(3) Customs, upon request of the holder of a trademark or patent or other proprietary rights in accordance with the relevant procedures, may prohibit the release into free circulation, and the exportation of goods, provided that they are recognized in accordance with applicable Law to be counterfeited or pirated goods. 


\section{CUSTOMS DECLARATION}

Article 53 (Assigning a Customs Designation for Non-afghan Goods)

(1) Customs are obliged to assign a customs designation for

Non-Afghan goods presented at customs in accordance

with customs legislation.

(2) Customs may, for reasons of public morality, public security, protection of environment, health and life of humans, animals or plants, the protection of national treasures possessing artistic, historic or archaeological value or the protection of industrial and commercial property and other state policies, adopt prohibitions or restrictions in accordance with relevant legislative instruments.

\section{Article 54 (Time Period for Completing a Customs Declaration)}

(1) The declarant is obliged to complete required customs declarations within 5 days from the date on which the summary declarations were submitted.

(2) Where circumstances so warrant, Customs may set a shorter period or authorize an extension to the periods referred to in paragraph 1.

(3) The temporary storage period shall be 30 days and it will terminate at any time that duties, storage and other obligations accrued under this law equal the value of the goods. In no event shall the period be extended in the absence of a complete report by the responsible customs authority to the General Directorate of Customs justifying the delay.

Article 55 (Declaration of the Goods for a Customs Process)

(1) A request to place goods under an initial customs process or for release of goods shall be made in the customs

declaration.

(2) Customs declarations must be made in accordance with the customs requirements in one of the following acceptable

formats:

1- In writing ; or

2- By an oral declaration

3- Using data-processing techniques; or

4- any other act by which the person responsible for the goods

expresses his wish to place goods under a Customs

designation or process

(3) The customs declaration shall be accompanied by the customs documents required in accordance with the relevant procedure governing the requested customs designation or process.

\section{Article 56 (Acceptance of the Declaration)}

(1) Declarations, which are prepared or submitted by the person responsible for goods in compliance with the conditions laid down in Article 55 shall be accepted by Customs without delay, provided that the goods to which they refer can be made available for customs inspection.

(2) Where acceptance of a customs declaration requires the fulfillment of additional obligations by persons, such person 
shall sign it upon being required by Customs to do so.

Article 57 (Voluntary Amendment or Withdrawal of Declarations)

(1) The declarant may amend one or more of the particulars of the accepted declaration, in case of unintentional error, or to make a change in the customs designation or process of the goods, or to withdraw the customs declaration, provided that the amendment or withdrawal does not apply to goods other than those originally covered.

(2) No amendment or withdrawal shall be permitted in the following circumstances:

1- during the period after Customs have informed the declarant that they intend to examine the goods; or,

2- if Customs have established that the declaration has been prepared in violation of chapter 14 of this law.

\section{Article 58 (Verification of the Declaration)}

Customs may verify any customs declarations and attached documents and may require the declarants to present other documents, or examine the goods and take samples for analysis or for detailed examination.

\section{Article 59 (Composite Declaration)}

The declarant may file a single declaration form covering two or more types of goods. In such case the particulars relating to each type of goods shall be deemed to constitute a separate declaration.

\section{Article 60 (Partial Control)}

Where only parts of the goods covered by a declaration are examined or sampled, the results of the partial examination shall be taken to apply to all the goods covered by that declaration. The declarant may request a further examination of the goods if he is not satisfied with the results obtained.

\section{Article 61 (Identification of the Goods)}

(1) Customs shall for the purpose of complying with the procedure for assigning a customs designation or process for the goods included in the declaration, identify the goods when required and assure themselves.

(2) Labeling which is affixed to goods under customs supervision for the identification of the goods, shall be removed or destroyed only by Customs, or with their permission. The person responsible for goods may remove or destroy such labeling in unforeseeable circumstances or force majeure, provided that he proves the occurrence of force majeure.

\section{Article 62 (Release of Goods)}

(1) Where the goods are placed under a customs designation or process in accordance with this law, Customs shall release the goods as soon as the particulars in the declaration have been verified to their satisfaction.

(2) Assigning an initial customs designation, or release from any transit process of all goods covered by the same declaration shall take place at the same time. 
(3) Goods shall not be released unless a customs debt due, penalties due, and any other obligations (eltazamat) under this law, have been paid or security or assurances are provided.

(4) Paragraph 3 shall not apply to amounts of the customs debt not yet due for goods in the temporary importation process.

\section{Article 63 (Goods Ineligible for release)}

(1) Goods ineligible for release shall be goods for which: 1 - it has not been possible to undertake or continue examination within the period prescribed for reasons attributable to the declarant; or,

2 - customs have not been presented the customs documents required for a requested customs process; or, 3- payments due for customs duty, or security, or other arrangements, have not been made or provided within 3 days after being placed in a designation; or, 4- goods are not removed from customs facilities within 10 days after their release; or

5 - goods have been the subject of termination of temporary storage in accordance with Article 54(3); or 6- goods have been determined as being subject to prohibitions included in paragraph (2) article 53 of this law, provisions of smuggling or confiscation orders by the competent authorities referred to in this law.

(2) Customs in accordance with the relevant procedures, shall be authorized to impose additional storage charges, seize or sell the goods referred to in paragraph (1), provided that they make prior notification to the person responsible for the goods.

Article 64 (Customs Amendment or Invalidation of Declarations)

(1) Customs may amend or invalidate the declaration after release of the goods where the designation was made on the basis of incorrect or incomplete information.

(2) In cases where the declarant provided the information referred to in paragraph 1 , incorrectly in violation of Articles 166(2) and 172, the customs shall apply the designatd sanctions provided for in Articles 166 and 173 and assign a new customs designation on the basis of the correct and complete information.

\section{CHAPTER 10 CUSTOMS PROCESSES}

\section{Article 65 (Release of Goods for Free Circulation)}

(1) Non-Afghan goods shall be deemed Afghan goods after release for free circulation.

(2) Release for free circulation shall be subject to application of commercial policy measures, completion of all requirements for importation of goods, and the collection of the customs debt.

Article 66 (Conditional Release of Goods)

When goods are released at a favorable tariff rate, they shall remain under customs supervision. This Customs 
supervision shall end only when the goods are released for free circulation, or when the goods are exported, abandoned to the state or destroyed. Use of the goods for the purposes other than those laid down for the application of the favorable tariff is permitted only subject to payment of the remaining duty due.

\section{Article 67 (Classification of Mixed Goods)}

When a consignment is made up of goods falling within different tariff classifications, and drawing up the declaration for each tariff classification would entail a waste of time or additional expenses disproportionate to the import duty chargeable, Customs may, with the agreement of the declarant, charge the highest level of import duty on the whole consignment based on the tariff classification of goods. In such case the declarant will be responsible only for estimating the proportionate amount of each type of goods in the consignment.

\section{Article 68 (Loss of Customs Status as Afghan goods)} Goods released for free circulation shall lose their customs status as Afghan goods when the declaration is invalidated in accordance with Article 64.

Article 69 (Customs Processes with Economic Impact)

(1) The term 'customs processes with economic impact' means the following processes:

1- Customs warehousing;

2- Inward processing;

3- Processing under customs control;

4- Temporary importation;

5- Outward processing.

(2) 'Goods in unaltered state' means goods which have undergone no form of inward processing.

\section{Article 70 (Conditions for Granting an Authorization)}

(1) The use of any customs processes with economic impacts shall be conditional upon permission being issued by the Ministry of Finance.

(2) The permission to use customs process with economic impacts and the authorization provided for in this law shall be granted to persons who offer the necessary security and when Customs are able to supervise the process.

(3) The conditions under which the process with economic impact in question is used shall be set out in the authorization.

(4) The holder of the authorization shall be obliged to notify the Customs of all factors arising after the authorization was granted which influence its continuation or contents.

\section{Article 71 (Security)}

The customs may make the placing of goods under a suspensive process conditional upon the provision of security. The conditions concerning the provision of security shall be provided in the relevant procedure. 
Article 72 (Release From the Processes with Economic Impact)

(1) Customs processes with economic impact shall end when a new customs designation is assigned either to the goods placed under that process or to the compensating /processed products related to those goods.

(2) Customs shall take the measures necessary to assign a new customs designation for goods of which a suspensive process has not been implemented as required by the provisions of this law.

\section{Article 73 (Transfer of Rights and Obligations)}

The rights and obligations of the holder of an authorization for customs processes with economic impact may, be transferred to other persons provided that the other persons undertake to comply with all associated conditions and requirements in accordance with the relevant procedures.

Article 74 (The Time for Determining the Customs Debt) (1) The amount of customs debt, for suspensive goods shall be determined at the time of acceptance of the relevant declaration.

(2) Suspensive goods may be subject to re-evaluation at the time of release for free circulation, in accordance with the relevant procedure.

(3) At the time of acceptance for the process of release for free circulation or conditional release, suspensive goods shall benefit from any favorable tariff that would have applied to the goods at the time of placing the goods in the suspensive process.

\section{Article 75 (Transit Process)}

(1) The transit process is the procedure applied to goods that have entered Afghanistan with the intent of moving through Afghanistan to another country.

(2) The transit process shall also be applied to goods placed under a customs process, or other customs control or supervision, and are moved from one point to another within the customs territory of the State.

(3) The transit process shall not involve the assessment of duties or application of commercial policy measures.

(4) The transit process may be used in combination with another customs designation or process.

(5) The transit process may include such alternative arrangements as may be established by relevant procedure pursuant to international conventions and agreements.

(6) Where customs determine that non-Afghan goods are in transit to a destination in Afghanistan, and have not complied with the requirements of the transit process, the related customs of the relevant customs house, in addition to collecting the appropriate amount due from the security, may seize the goods, and deal with them in accordance with law

Article 76 (Release From the Transit Process)

The transit process shall end in the condition mentioned in Article 72(2) or when the goods and the corresponding 
documents are produced at the approved destination customs office in accordance with the relevant procedure.

\section{Article 77 (Transit Via Third Countries)}

The transit process shall apply to goods passing through a third country and reentering Afghanistan without assigning a new customs designation, in cases provided for by international agreement.

\section{Article 78 (Transit Security)}

(1) Transit Security shall be provided in accordance with Article 137 for insuring the payment of any customs debt that is suspended in respect of transit goods.

The following shall be an exception:

1- carriage by air;

2- carriage by pipeline;

3- operations carried out by a railway company of the State; 4- other cases as determined by the Ministry of Finance

(2) The person responsible for goods in transit to a destination in Afghanistan pursuant to Article 35 shall be obliged to provide security in the amount of $110 \%$ of the customs debt.

\section{Article 79 (Exemptions from Giving Security)}

(1) Any person satisfying the following conditions may, subject to the limits of paragraph 2, obtain from the customs a security waiver certificate waiving the security requirements of Article 78 for transit goods:

1- Who are established in Afghanistan;

2- Who are continual users of the transit process;

3- Whose financial situation is such that they can meet their commitments;

4- Who have not committed any violation of customs or fiscal laws; and

5- Who, in accordance with the determined procedure, undertake (promise) to pay, upon the first application in writing by the customs, any sums due on account of their transit operations.

(2) The security waiver granted in accordance with paragraphs 1 shall not apply to transit operations involving the following goods:

1- Goods with a customs debt exceeding Afs. 200,000 or such other amount as proposed by the Ministry of Finance and approved by the Council of Ministers; or 2- Goods which present increased risks because of the level of import duty applicable [to them] in Afghanistan.

(3) The General Directorate of Customs shall be authorized to grant security waiver certificate. The certificate shall be valid for a period of six months and certified copies of the security waiver certificate shall be issued to the relevant persons. The period may become extended.

\section{Article 80 (Obligation of Persons Responsible for Transit Goods)}

The owner of transit goods or his agent shall be obliged to present the goods and the related customs documents intact, in accordance with procedures, at the relevant designated customs office by the prescribed time limit to ensure 
identification of the goods.

Article 81(Customs Warehousing)

(1) Goods shall be placed in warehouses approved by customs for the purpose of storing them under prescribed conditions, under the supervision of customs. The warehouses operated directly by Customs responsible authorities, or by warehouse keepers in a customs area are also included in this provision.

(2) The customs warehousing process shall allow the storage in customs warehouses of :

1- non-Afghan goods, without such goods being subject to import duty or commercial policy measures;

2- Export Afghan goods, when customs legislation requires that the goods be placed in a customs operated warehouse.

(3) Upon the request of the declarant, the Ministry of Finance may determine the cases in which the goods referred to in paragraph 2 can be placed under the customs warehousing process without being stored in a customs warehouse.

\section{Article 82 (Warehouse types)}

A customs warehouse may be established in the following forms: 1- official customs warehouses established exclusively by the Ministry of Finance.

2- public customs warehouses which are established by individuals and are open to all exporters and importers.

3- private customs warehouses established by its owner for his own use.

Article 83 (Warehouse Keepers and Their Responsibilities)

The customs warehouse keeper shall be responsible for: 1- Except as provided in Article 89, preventing the removal of goods from the customs warehouse which are subject to customs supervision.

2- Implementing the conditions established by the customs warehousing process, in accordance with the relevant procedure.

3- Keeping records and other obligations specified in the relevant procedure.

Article 84 (Approval to Operat a Customs Warehouse) (1) Approval for establishing Customs warehouses shall be issued by the Ministry of Finance, except for official customs warehouses operated by customs.

(2) Conditions for granting authorization and conditions for the operation of warehouses shall be regulated in a separate procedure.

(3) For public and private warehouses operated within customs areas, on land leased for this purpose, no demurrage charges shall be collected, and the area leased will remain under the control of the warehouse keeper. Duties on goods stored in such a warehouse will be postponed until goods are place under customs process and shall be paid by the declarant who declares the goods for a process involving release of the goods from the customs area. 


\section{Article 85 (Transfer of Rights and Responsibilities)}

The rights and obligations of a customs warehouse keeper may, with the agreement of the authorized customs, be transferred to another person who is eligible pursuant to the relevant procedure.

\section{Article 86 (Distinctive Cases)}

(1) Where an economic need exists and customs supervision is not adversely affected thereby, the customs may allow the storage of the following goods in customs warehouses:

1- Afghan goods other than those referred to in Article 81 (2)

(2). In this case the conditions of the customs warehousing process shall not apply.

2- Non-Afghan goods to be processed on the premises of a customs warehouse under the inward processing process or processing under customs control, and the conditions provided for by those processes be complied with. The relevant exceptions in this context shall be determined in accordance with the related procedures.

(2) The warehouse keeper shall be obliged, on request of the customs, to enter the goods referred to in Paragraph 1, in the stock records in accordance with Article 83 (3).

Article 87 (Time Limits for Storage in Warehouses)

(1) The goods may remain under the customs warehousing process for a period up to twelve months. Customs, on the declarant's request, may accept an extension up to 12 months.

(2) Where special circumstances so warrant, Customs may set a shorter limit for the time provided in paragraph (1).In this case until the end of such a time, the declarant must assign the goods another customs designation.

Article 88 (Handling of Goods Under a Customs Warehousing Process)

(1) Goods under the customs warehouse process may undergo different forms of handling intended to preserve them, improve their appearance or marketable quality, or prepare them for distribution or resale. The list of the permitted handling operations shall be provided by the Ministry of Finance in the relevant procedures.

(2) The declarant shall be obliged to receive prior authorization from customs for the forms of handling operations provided for in paragraph 1. Customs will stipulate the conditions under which the handling operations may take place.

\section{Article 89 (Temporary Withdrawals from Warehouses)}

(1) When circumstances so warrant, goods placed under the customs warehousing process may be temporarily removed from the customs warehouse, provided that such removal is authorized in advance by the customs.

(2) The conditions for such withdrawal shall be stipulated in the authorization.

(3) The goods referred to in paragraph (1) of this article, may undergo the forms of handling referred to in Article 88 of this law. 


\section{Article 90 (Transfer of Goods)}

Customs may allow goods placed under the customs warehousing process to be transferred from one customs warehouse to another.

\section{Article 91 (Customs Value of Warehoused goods.)}

(1) The cost of warehousing and of preserving goods while they remain in the warehouse need not be included in the customs value stated by the declarant if they are shown separately from the price actually paid or payable for the goods.

(2) Where the goods mentioned in paragraph 1 have undergone the usual forms of handling within the meaning of Article 88 , the type of the goods, the customs value and the quantity for the pupose of determining the amount of import duty shall, at the request of the declarant, be those that would have be taken into account for the goods, at the date referred to in Article 74 as if they had not undergone changes due to such handling.

(3) Any exceptions to the changes in valuation under paragraph 2 shall be provided for in the relevant procedures.

\section{Article 92 (Inward Processing)}

The inward processing process shall apply to the following imported goods:

1- "suspensive goods" for export from the customs territory of the State in the form of compensating products;

2- goods that are placed under a drawback system and are exported in the form of compensating products from the customs territory of the state.

\section{Article 93 (Inward Processing Operations)}

(1) "processing operations": In connection with the inward processing of goods shall mean:

- The working of goods, including erecting or assembling Them or fitting them to other goods;

- The processing of goods;

- The repair or restoration of goods; and

- The use of certain goods defined in the relevant procedures, which are not to be found in the compensating products but which allow or facilitate the production of those products;

(2) "Compensating products": means all products resulting from processing operations excluding waste and scrap.

(3) "Rate of yield": the quantity or percentage of compensating products obtained from a given quantity of goods as a result of the processing operations.

\section{Article 94 (Application for Approval of Inward Processing}

Approval (juaz) of the inward processing process shall be granted, upon submission of a written application, by the Ministry of Finance in accordance with the relevant procedure and under the following conditions:

1- The applicant shall be established in Afghanistan, 2- When the suspensive goods can be identified in the compensating products, except as provided in Article 93 
(1) 4 .

3- When the process for inward processing best serves the economic interests of the country.

Article 95 (Time Period for Exportation of Compnesating Products)

Customs shall specify the period within which the compensating products must be exported, or assigned another customs designation, provided such period shall be sufficient to carry out the processing operations and to otherwise prepare the compensating products for a new customs designation.

Customs may grant an extension at the request of the holder of the Approval.

Article 96 (Rate of Yield of Inward Processing)

(1) Customs shall set either the rate of yield of the operation or the method of determining such rate based on the actual circumstances in which the processing operation shall be carried out.

(2) The standard rate of yield shall be determined in the Approval, on the basis of information submitted in the Application.

Article 97 (Release for Free Circulation from Inward Processing)

In case goods in the inward processing process, whether in

an unaltered state or as compensating products, are missing at the period provided in Article 95, they shall be deemed to have been released for free circulation and the holder of an inward processing Approval shall be obliged to submit a customs declaration for such missing goods and shall be liable for the customs debt.

Article 98 (Compensating Products of Inward Processing)

(1) Compensating products that are re-imported after being exported are subject to customs duty.

(2) The customs debt on goods mentioned in paragraph one

shall, at the request of the importer, be calculated in

accordance with Article 97.

\section{Article 99 (Customs Duties on Compensating Products of Inward}

Processing)

(1) The compensating products shall be dutiable at the same rate as identical imported goods;

(2) In case a favorable tariff is applied by virtue of the intended use of the identical imported goods, the same favorable tariff shall also be applicable on compensating products.

(3) In case the identical goods imported in accordance with article 27 of this law become duty free, the compensating products shall also be exempted from paying duty.

(4) The Ministry of Finance may designate the duty rate for compensating products in those situations where the duty rate on a compensating product would be less than the duty rate on the related suspensive goods.

Article 100 (Compensating Products of Inward Processing After Outward Processing) 
Some or all of the compensating products or goods in unaltered state may be temporarily exported for further processing in a foreign country if the customs authority so authorizes in accordance with the provisions governing outward processing in Articles 116-121 and the relevant procedures.

\section{Article 101 (Drawback Cases)}

(1) An Approval under Article 94 may authorize use of the drawback system, except for goods the importation of which is subject to quantitative import restrictions.

(2) No drawback amount will be refunded in excess of duties actually paid in accordance with the drawback system.

\section{Article 102 (Drawback Declaration)}

The customs declaration shall indicate the use of drawback system and a copy of the Approval granted under Article 94 must be attached.

Article 103 (Temporary Exportations Pursuant to Drawbacks) Temporary exportation of compensating products carried out as provided for in Article 100 shall be considered as exported within the meaning of Article 104 where such products are not re-imported into Afghanistan within the period prescribed.

\section{Article 104(Drawback Refunds)}

(1) The import duty shall be refunded to the holder of the Approval described in Article 102 when compensating products are exported, provided that all conditions for use of the process have been fulfilled.

(2) The drawback refund must be claimed within one year, unless a shorter period is provided in the Approval. If the goods have not been exported by the time of the expiration of the drawback refund period, they shall be deemed to be goods released for free circulation.

\section{Article 105 (Processing Under Customs Control)}

Processing under customs control allows suspensive goods to be processed as described in Article 93 (1), without payment of duty or application of commercial policy measures, provided duty is paid on the compensating products when they are released for free circulation at the rate for identical imported goods.

\section{Article 106 (Approval for Processing Under Customs Control)}

Approval for processing under customs control shall be granted by the Ministry of Finance upon submission of a written application by the applicant, in accordance with the relevant procedures under the following conditions:

1- The applicant must be established in Afghanistan 2- Where the suspensive goods can be identified in the compensating products;

3 - where the goods cannot be economically restored after processing to their description or state as it was when they were placed under the process; 
4- when usage of the process best serves the economic interests of the country

Article 107 (Approval Contents For Pocessing Under Customs Control)

The Approval for processing under customs control shall

contain:

1- Satisfaction of the conditions stated in Article 106;

2- the standard rate of yield as described in Article 96;

3- The date by which the compensating products shall be

assigned a new customs designation.

Article 108 (Debt Amount if Processing Under Customs Control is Not Completed)

For goods in unaltered state or are at an intermediate stage

of processing, the amount of the debt shall be determined as

if these goods had been presented for free circulation at the

time of acceptance of declaration for placing the goods

under the process for processing under customs control.

Article 109 (Import of Compensating Products Processed Under Cutoms Control)

(1) Compensating products are dutiable at the same rate or favorable tariff as would be applicable to identical imported goods

(2) Commercial policy measures that would otherwise apply to comparable imported goods will not be applied to Compensating products.

\section{Article 110 (Temporary Importation Process)}

Suspensive goods intended for export which are assigned a temporary importation process, shall be either totally or partially relieved from import duty and commercial policy measures, provided they undergo no change, except for normal depreciation, while in the customs territory of the State.

Article 111 (Approval for Temporary Importation)

(1) Approval for temporary importation shall be granted in accordance with the relevant procedures by the Ministry of Finance.

(2) The customs declaration shall indicate if the temporary importation process is being used, and shall attach a copy of any Approval granted under Section 1.

Article 112(Conditions for Approval for Temporary Importation)

(1) The temporary importation process may be used only for suspensive goods that:

1- May be easily identified,

2- The situations in which the absence of identification measures in view of the nature of the goods or of the operations, is not liable to give rise to any abuse of the process.

3 - Will not remain under the temporary importation process in excess of 12 months, unless extended up to an additional 12 months for good cause.

(2) Customs may limit the period within which the temporarily imported goods must be exported. The period assigned must be sufficient to accomplish the intended purpose of the 
temporary importation process. The declarant is responsible for submitting a declaration for a new customs process or designation, before the expiration of the designated period, and in case of any violation of the other terms of the approval.

(3) In a special case where an economic need exists, upon the proposal of the Ministry of Finance, the Council of Ministers may prescribe a period up to 6 years for goods to remain in temporary importation.

(4) Temporarily imported goods shall remain non-Afghan goods until placed under another customs process.

Article 113 (Special Conditions for the Temporary Importation Process)

(1) The temporary importation process with total relief from import duty shall be used for goods :

1- for which, at the end of the temporary importation period, there would be no fair anticipated market for the goods in Afghanistan

2- equipment that temporarily replaces goods exported for repair;

3- Which are "tools of trade" (in accordance with the relevant procedure) of a skilled worker including musical, artistic and, sporting equipment?

(2) Use of the temporary importation process with partial relief from import duty may be granted to goods which do not fulfill the conditions mentioned in paragraph 1 .

(3) The relevant procedures may exclude categories of goods from the temporary importation process.

Article 114 (The Duty Amount Payable for Goods Under the Temporary Importation Process with Partial Relief)

(1) Goods placed under the temporary importation process with partial relief from import duty shall be charged an import

duty, for each month or fraction of a month, of $3 \%$ of the duty which would have been payable on the said goods had they been released for free circulation on the date on which they were placed under the temporary importation process.

(2) The total amount of import duty to be charged under paragraph 1 shall in no event exceed the amount which would have been charged if the goods concerned had been released for free circulation on the date on which they were placed under the temporary importation process.

(3) Goods mentioned in Paragraph 1 will be treated as nonAfghan goods until the duties and any other customs debt is paid in full

Article 115 (Change of Customs Dsignation of Temporarily Imported Goods)

(1) Suspensive goods under the temporary importation process may be assigned another customs designation if a new customs declaration is filed prior to the expiration of the temporary period.

(2) In case goods under a temporary importation process are given a new customs designation, the amount of payments made pursuant to Article 114 shall be deducted from the customs debt.

(3) In case of sale or other transfer of goods, the holder of the 
approval shall be liable to pay the amount of import duty due under Article 114 or the duty due under any new customs designation.

\section{Article 116 (Outward Processing)}

Afghan goods under the outward processing process which are called temporarily exported goods may be temporarily exported for processing. The returned goods resulting from those operations may be released for free circulation in the customs territory of the State with a reduction of import duty.

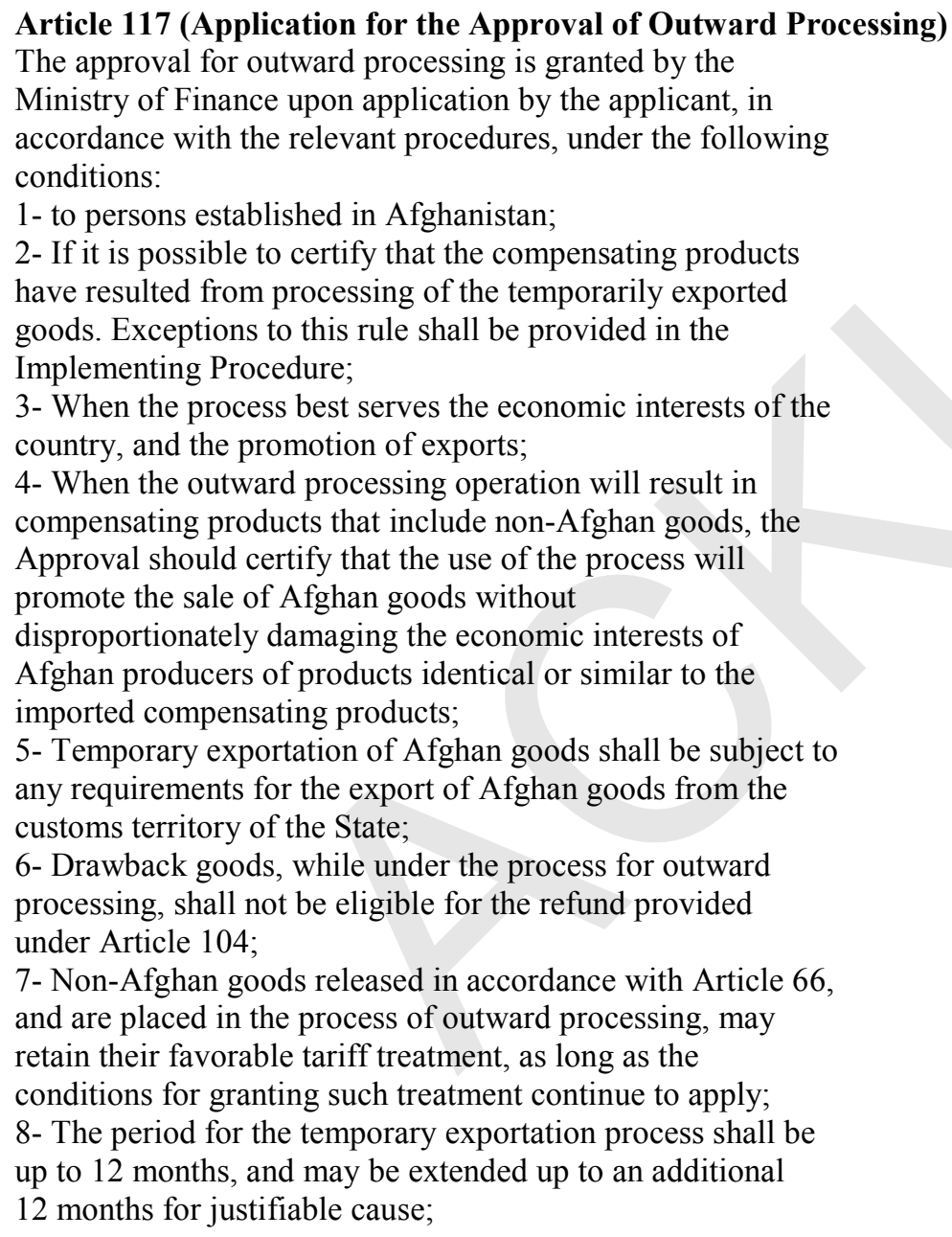

\section{Article 118 (Contents of Outward Processing Approval)}

The approval for outward processing shall include:

1- The date by which the compensating products must be reimported, taking into account the time required to carry out the processing operations.

2- The standard rate of yield.

3- The value of the temporarily exported goods, calculated as

of the date the Application is made.

Article 119 (Import Duty for Compensating Products of Outward Processing) 
(1) The import duty on compensating products under the process for outward processing shall be imposed on the value added to the temporarily exported goods, which shall be calculated in accordance with Article 24. If the added value is less than $5 \%$ of the value of the goods, no duty will be charged.

(2) The import duty on the compensating products shall be assessed at the tariff rate applicable to its tariff classification.

Article 120 (Goods Repaired Without Charge in Outward Processing)

(1) When the purpose of processing operations is the repair of temporarily exported goods, the compensating products shall be released for free circulation with an exemption from import duty, when it is established to the satisfaction of Customs that the goods were repaired free of charge, either because of a contractual or statutory obligation arising from a guarantee or because of a manufacturing defect.

(2) Paragraph 1 shall not apply where the customs debt took account of the defect at the time when the goods in question were first released for free circulation.

(3) For goods mentioned in Paragraph 2, and for goods repaired at expense, adequate documentation shall be submitted concerning the cost of the repair for purposes of determining the added value.

Article 121 (Transfer of Rights of the Outward Processing Approval)

Rights of the holder of the Approval under this process may be transferred to any other person established in Afghanistan who fulfills the conditions.

\title{
Article 122 (Export Process for Afghan Goods)
}

(1) Afghan goods leaving the customs territory of the State shall, by means of an export customs declaration, be placed in the export process at the competent customs office. The border customs office shall supervise the exit of exported goods from the customs territory,

(2) Goods provided for in Paragraph 1 may obtain the permission for release for export provided the goods are in the same condition as when the declaration was accepted.

\section{Article 123 ( Exportation of Non-Afghan Goods)}

The export of non-Afghan goods shall be carried out under customs supervision but without submission of a new customs declaration or otherwise being subject to the export process.

\section{CHAPTER 11 \\ FREE ZONES AND FREE WAREHOUSES}

\author{
Article 124 (The Meaning of Duty Free Zones) \\ Duty free zones, free warehouses and duty free shops shall \\ be a separate part of the customs territory of the State, in \\ which non-Afghan goods are considered, for purposes of \\ import duty and commercial policy measures, as not being \\ on Afghan customs territory.
}


Afghan goods may enter such areas in accordance with the relevant procedure.

\section{Article 125 (Free Zones Designation)}

(1) The Ministry of Finance shall be authorized to designate parts of the customs territory of the State as free zones and approve construction of any building in a fee zone.

(2) The geographical boundaries and the entry and exit points of each free zone and free warehouse shall be determined exactly by the Ministry of Finance. The holder of approval is obliged to wall off the related zone or warehouse.

(3) The Ministry of Finance may authorize opening of duty free shops in the customs territory of the State for the sale of goods with exemption from import duty. The method of using free duty shops shall be regulated in the relevant procedures.

\section{Article 126 (Customs Supervision in Free Zones)}

(1) Free zones, duty free shops, and free warehouses, and their borders and entry and exit points shall be subject to customs supervision and control.

(2) Persons and means of transport entering or leaving a free zone or free warehouse shall be subjected to a customs inspection.

(3) Persons who do not provide the security required by Customs legislation and procedures can not use free zones or free warehouses.

(4) When goods enter or leave a free zone or free warehouse, a copy of the transport document shall accompany the goods and be provided to the customs.

\section{Article 127(Conditions for Entrance and Exit of Goods)}

(1) Prohibited goods and goods that pose a threat to public safety or health shall not be admitted to duty free zones, free warehouses, and free shops.

(2) Goods entering and exiting a duty free zone, free warehouse, or free shop shall first be presented to the customs, but the person responsible for goods need not accompany them by a customs declaration unless the goods are placed into a customs process. The value of goods placed into a customs process shall be calculated in accordance with Article 24.

(3) When goods enter a duty free zone, free warehouse, or free shop from another part of the customs territory of the State, Customs shall release the goods from a previous customs process, and place Afghan goods into the export process, unless otherwise provided in customs legislation:

(4) The Customs debt on Afghan goods exiting the free zone free warehouse, or duty free shop into another part of the customs territory of the State shall be calculated in accordance with Article 119.

(5) Goods may exit a duty free zone, free warehouse, or free shop for export from the customs territory of the State in accordance with the relevant procedures.

Article 128 (Customs Status of Goods in Duty Free Zones) 
(1) The customs may provide, on request of the person responsible for goods, a certificate stating the customs status of goods placed in a duty free zone, free warehouse, or free shop.

(2) If the certificate, or other documents that prove the customs status of the goods, cannot be presented, the goods shall be considered to be Afghan goods, for the purposes of export from the customs territory of the State and Non-Afghan goods in case of entry into another part of the customs territory of the State.

\section{Article129 (Time Limits)}

There shall be no limit to the length of time goods may remain in free zones free warehouses, or duty free shops, unless otherwise provided in the relevant procedures.

\section{Article 130 (Authorized Activities)}

(1) Carrying out any industrial, commercial, or service activity shall, under the conditions laid down in Customs Legislation, be authorized in a free zone, warehouse or duty free shop without complying with the provision of Article 88.

(2) All nationally enforced laws, including those for the protection of patents, trademarks, and copyright are applicable to free zones.

(3) The customs may impose necessary prohibitions or restrictions on the activities referred to in paragraph 1 , having regard to the nature of the goods concerned or to the needs of customs supervision.

\section{Article 131 (Approved Registers)}

All persons engaged in storing goods, or carrying on any activity under Article 130(1), in a duty free zone, free warehouse, or free shop, shall enter the goods in the stock records when received, and maintain the stock records in accordance with the orders of customs.

\section{Article 132(Tariff on Consumed and Missing Goods)}

(1) Goods consumed for daily needs or for maintaining or otherwise supporting the purposes of free zones, as provided in the relevant procedures, shall be regarded to be released for free circulation and shall be subject to payment of customs duty.

(2) Where goods disappear and when their disappearance cannot be explained to the satisfaction of the customs, the goods shall be regarded as having been consumed in the free zone, free warehouse, or free shop and Paragraph 1 shall be applied.

Article 133 (Abandonment or Destruction of Goods in Free Zones)

Customs may designate for abandonment, or destruction, under Article 134 of Non-Afghan goods placed in a free zone or free warehouse while they remain in a duty free zone, free warehouse or free shop.

\section{CHAPTER 12}




\section{CUSTOMS DESIGNATIONS}

Article 134 (Destruction or Abandonment )

(1) A destruction or abandonment designation shall be made as described in the relevant procedures. The declarant, or other person responsible for the goods, must provide a customs declaration requesting the relevant designation.

(2) The destruction or abandonment designation shall be denied if it entails an expense for the State.

\section{Article 135 (Destruction of Goods)}

(1) The destruction designation shall be carried out by prior notification to Customs. The notification shall state with specificity the goods to be destroyed, the time, the place, the means of destruction, and the reason for destruction.

(2) Customs may supervise the destruction process and require presentation by the person responsible for the goods of related customs documents and a copy of the notification provided in Paragraph 1.

(3) Any waste or scrap resulting from such destruction shall retain the status of non-Afghan goods and shall remain under customs control until such time as it is released to another customs designation or process.

\section{Article 136(Proceeds From Abandoned Goods)}

Proceeds from the sale of transfer [disposal] of goods designated as abandoned to the state shall be deposited to the relevant account in accordance with the procedure for payment of customs debts. The Director General of Customs may provide for transfer of abandoned goods to a state institution or administrations when the cost of disposal does not merit the relevant expenses.

\section{CHAPTER 13 CUSTOMS DEBT}

\section{Article 137 (Form of Security)}

(1) Unless otherwise provided by the relevant procedures, security required under this law for payment of a customs debt shall be provided at the choice of the customs debtor by the means of cash deposit or a guarantee by a reliable person or institution.

(2) If the customs are not sure that the customs debt mentioned in paragraph 1 is to be paid within the prescribed period, they may submit an appropriate proposal to the relevant authority justifying the provision of a security.

(3) The mentioned authority of paragraph 2 may order a customs debtor to provide security necessary for satisfying the customs debt.

\section{Article 138 (Single Security for Several Actions)}

The customs may allow a single security to be provided to guaranty customs debt for two or more operations.

\section{Article 139 (Securities Levels)}

(1) Customs can fix the amount of security as following: 
1- Unless otherwise provided in customs legislation, according to the precise amount of the customs debt in question where that amount may be established with certainty at the time when the security is required 2- Where no precise or other fixed amount can be determined, according to the maximum amount of the customs debt estimated by Customs.

(2) If the security provided for in article 138 is required for customs debts which may vary in amount over time, it shall be set at a level sufficient to enable the customs debts in question to be covered at all times.

\section{Article 140 (Cash Deposits)}

A cash deposit shall be made in Afghan currency. The following shall also be deemed a cash deposit:

1- Submission of a check, the payment of which is guaranteed by the institution on which it is drawn which is approved by relevant rule.

2- Submission of any other financial instrument accepted by the customs as a means of payment.

Article 141 (Guarantor)

Any person who meets the following criteria may be accepted as a guarantor:

1- Must be a person established in Afghanistan, unless provided otherwise in the international agreements to which Afghanistan is a party.

2- Shall provide a guarantee, to pay the unpaid secured amount of a customs debt in a form satisfactory to customs. 3- Shall provide a guarantee that will be maintained until a specific time, as may be determined by customs.

\section{Article 142 (Other kinds of Security)}

Customs may accept other kinds of security, provided that they can provide equivalent assurance that the customs debt will be paid.

\section{Article 143 (Additional Securities)}

When Customs establishes that the security provided is not certain or sufficient to ensure payment of the customs debt within the prescribed period, they shall require the customs debtor to either provide additional security, or at the customs debtor's option, to replace the original security.

\section{Article144 (Release of Security)}

(1) When the customs debt has been extinguished in part, unless the amount is insufficient to justify such action, a part of the cash deposit shall be repaid to the customs debtor upon a request by the debtor.

(2) When a secured customs debt is extinguished, the non cash security shall be released and the cash deposit returned without delay.

Article 145 (Lawful Activities Which Cause Customs Debts)

(1) A customs duty on lawful importation or exportation of goods may be incurred when goods have been released for 
free circulation in accordance with this law or by the filing of an accepted customs declaration for:

1- the release for free circulation of goods liable to import duty in accordance with Article 65(2);

2 - the placing of goods under the temporary importation process with partial relief from import duty.

3 - the placing of goods in conditional release of goods under customs supervision;

4- the placing of goods in the export process;

5 - placing of goods in any other customs process or designation involving payment of duty (tarifa), charges (haq ul zamat), dues (awarez), penalties (jerima), or other monetary obligations (eltezamat e puli)

(2) A customs debt shall be incurred after customs notifies the customs debtor, whether upon acceptance of the declaration, or assessment of penalties in accordance with this law.

Article 146 (Unlawful Activities Causing a Customs Debt) A customs debt with respect to unlawful activities shall be incurred by violation of Articles 166 (2) and 170.

Article 147 (Customs Debt on Removal of Goods from Supervision Without Permission) A customs debt shall also be incurred on goods removed from customs supervision without permission. And, the customs debtor shall be:

1- the person who removed the goods from customs supervision without permission,

2- any persons who participated in such removal and who had prior awareness that the goods were being removed from customs supervision.

3- any persons who acquired or held the goods subject to customs supervision or control and who were aware at the time of acquiring or receiving the goods that they had been removed from customs supervision.

Article 148 (Non Occurrence of Debt)

No customs debt shall be deemed to be incurred in respect of goods under customs supervision that were:

1 - lost due to force majeure;

2- placed in a destruction or abandonment designation under Article 134;

3 - lost to evaporation or other natural process; or

4- were out of the control of the person when they were the subject of Article 146 and 147, and that person proves it.

\section{Article 149 (Responsibility of Partnerships)}

Where a partnership has guaranteed a customs debt, the general partners shall be jointly and severally liable for such debt. The penalty portion of the debt shall be an exception from this rule.

\section{Article150 (Date of Determining Customs Debt)}

Where it is not possible to determine precisely when the customs debt is incurred due to the fault of the declarant, the highest rate of customs duty applicable during the period in question shall be applied. 


\section{Article 151 (Entry of Debt Into Accounts)}

(1) The Customs duty shall be calculated by Customs simultaneously with the acceptance of a customs declaration which entails payment of duty. If additional information is required by Customs to determine the valuation of goods, Customs shall calculate the customs duty no later than 48 hours after the customs declarations is accepted, or for such other period of time as may be fixed in the Procedure (tarzulamal) for Customs Valuation. The amount of the customs duty shall be entered into the accounts without delay after it has been calculated, (2) Unless other wise provided for in this law and its procedures, the customs duty must be calculated and entered prior to the release of the goods for free circulation, or for another process that entails payment of customs duty, in accordance with Article 62.

(3) A customs debt incurred after the goods have been placed under a customs process shall be entered in the accounts within 48 hours after customs has information sufficient to calculate the customs debt, and determine the debtor.

(4) The customs officials shall adequately explain any delays in making the entry of a customs debt.

\section{Article 152 (Differences in Account Entries)}

When a customs debt entered in the accounts is less than the amount legally owed, the customs are obliged to enter the correct amount in accordance with article 151, within 48 hours of the time Customs become aware of the situation.

\section{Article 153 (Notification about Debt Entry)}

(1) Customs officials are obliged to notify the amount of customs duty to the customs debtor at the time it has been entered in the accounts in accordance with the relevant procedures. The notification shall take place only where the amount stated in the customs declaration is different from the amount determined by customs.

(2) Re- determining the amount of customs debt shall not be valid after a period of 3 years.

Article 154 (Situations for Settling and Extinquishing Customs Debts)

A customs debt shall be settled or extinguished by the following means:

1 - by payment in full in accordance with this articles 154 to

158 ;

2 - by remission or refund in accordance with article 159 to

163 ;

3- by withdrawal or invalidation of a customs declaration entailing the obligation to pay duty, in accordance with Article 57 or 64;

4- if the goods are confiscated, or destroyed on the instructions of the customs; and

5- In circumstances described by Article 148 (1, 2 or 3).

Article 155 (Payment Term for Customs Debt)

(1) A customs debt notified in accordance with Article 153 shall be paid by the customs debtor in accordance with the 
following term:

1- Within the term prescribed in the notification. Article 156 shall be an exception to this provision.

2- An extension shall be granted automatically where the customs debtor does not receive the notification in the prescribed period.

(2) The customs at the request of the customs debtor may also grant an extension taking into account Article 152. The

extended time limit in any case shall not exceed 10 days;

\section{Article 156 (Deferral of Debt Payment)}

(1) The Ministry of Finance may provide in a separate procedure to allow deferral of payment of all or part of a customs debt, on condition that the customs debtor provides security and the period of deferral without charge shall not exceed 30 days. Where several customs debts are aggregated over a specified time period the delay in payment shall not exceed an average of 30 days.

(2) Customs may collect a charge (haq ul zamat) for providing the service of postponement of payment of $.01 \%$ of the deferred amount per day, or such other amount as is fixed by the relevant procedures.

(3) The amount of charge (haq ul zamat) referred to in paragraph 2 shall be determined by the Ministry of Finance so as to be comparable to similar charges in the domestic money or financial market.

\section{Article 157 (Manner of Payment)}

(1) A person other than the customs debtor may pay the customs debt.

(2) Payment shall be made by bank transfer, or by other instrument provided (darj) in customs legislation and procedures, or in cash if the payer is a person described in Article 45 or identified by customs.

Article 158 (Non Payment of Debt within the Prescribed Term)

(1) Customs shall be obliged to take all actions permitted by law to secure the payment of a customs debt that is overdue.

(2) The registered movable and immovable property of a customs debtor who fails to make timely payment of the customs debt shall be under security (that e tazmin) of customs. Information on the security may be provided to any registry of property, or banks by Customs. The security shall remain in effect until the customs debt is paid.

(3) Customs may, in accordance with law, collect a customs debt as a preferred creditor from a third party that has obligations to the customs debtor.

(4) Interest shall be charged on overdue customs debts in accordance with Article 156.

\section{Article 159 ( Refund or Remission of an Erroneous Entry)}

(1) A customs debt shall be refunded or remitted if the amount paid or entered into the accounts is proved to be in excess of the amount legally owed by the customs debtor.

(2) Refunding or remittance mentioned in paragraph 1 may take place upon withdrawal or submission of an amended custom 
declaration pursuant to Article 57 within a period of three years from the date on which the amount of the duty was notified.

(3) Customs shall be obliged to refund or remit the customs debt in the situations mentioned in paragraph 1 and 2 .

Article 160 (Remission or Refund for Defective Goods) (1) Import duty paid on defective goods, which have been damaged prior to release or are not compatible with the importation contract, and have been rejected by the importer, shall be refunded or remitted if:

1- the goods have not been used, except for such initial use as may have been necessary to establish that they are defective; and

2- The goods are exported, or placed in a process or designation that does not entail payment of customs duty.

(2) Goods mentioned in paragraph 1 may be exported as nonAfghan goods from the customs territory of the country.

(3) Import duty shall be refunded or remitted for the reasons set out in paragraph 1 upon submission of an application by the debtor within 12 months from the date of notification.

(4) Customs duty may be refunded in accordance with Article 104.

Article161 (Limit of the Amounts to be Refunded) Customs duties, except those collected under Article 45, shall be refunded only if the amount to be refunded exceeds Afghani 1000 or other amount fixed in the relevant procedures.

\section{Article162 (Interest on Refunds)}

No refund under articles 159,163, shall include payment of interest for the period prior to the refund decision. Interest, in accordance with Article 156, shall be paid to the customs debtor if the decision to grant a refund is not implemented within one month from the date of the refund decision.

\section{Article 163 (Erroneous Refunds)}

Customs debt refunded in error shall be re-paid by the customs debtor after notification of the error. Any interest related to the amount of refund under Article 162 shall also be included in this provision.

\section{CHAPTER 14 \\ CUSTOMS VIOLATIONS AND PENALTIES}

Article 164 (Customs Police Administration)

(1) A Customs Police Administration shall be created jointly by the Ministry of Finance and the Ministry of the Interior for the purpose of detecting and preventing violations of the provisions of this law and for arresting the relevant suspects throughout the Customs Territory of the State, in accordance with section 3 of this Article.

(2) Customs Police officials shall be part of the organization of the Ministry of the Interior. The Ministry of the Interior shall be responsible for: 
1- Approval, Employment, and dismissal of customs police, on recommendation of the Ministry of Finance, 2- Providing the Customs Police with salaries and any other incentives as provided by law 3- Recruiting, of Customs Police candidates, and maintaining their records (personnel files) 4- Providing appropriate uniforms and other equipment in accordance with the duties they perform, as agreed with the Ministry of Finance 5- Providing training for police candidates required to carry out their police duties

(3) The Ministry of Finance, as the agency responsible for directing and managing the work of the Customs Police shall have the following duties and authorities:

1- Determining the duties and scope of authority of Customs Police and determining their locations of work. 2- Providing for the necessary training for Customs Police concerning the administration and enforcement of the customs legislation 3- Recommending [to the Ministry of the Interior] remunerations and punishments for Customs Police and other personal matters of Customs Police affecting their work.

(4) The Ministry of Interior and the Ministry of Finance may jointly provide additional inter-ministerial guidelines implementing section 2 .

(5) The Ministry of Finance may, as required, provide procedures implementing paragraph 3 .

(6) Section 2 of this Article shall be effective for three year period upon enforcement of this law. The Ministry of Finance and the Ministry of the Interior may recommend its retention, amendment or deletion to the Council of Ministers. The approval of the Council of Ministers shall be regarded effective in this regard.

(7) Customs Police shall be obliged to perform their assigned duties in accordance with the provisions of this law, (the anti-smuggling law) and other guidelines and procedures only under the direction of the Ministry of Finance

\section{Article 165 (Customs Violations)}

Violations of customs law and other customs legislation shall be of the following two types:

1- Administrative violations; which are violations from all the provisions of this law ,except article 170

2- Smuggling of goods, in accordance with chapter 14 of this law.

\section{Article 166 (Administrative Violations and Sanctions)}

Administrative violations shall be classified in the

following three catagories:

(1) category one violations are as follows:

1- Delay

For delays in violation of Articles 36(2), 39(3), 51(1), $54(1), 80,87,95,112,118$, the penalty imposed shall be $0.01 \%$ of the duty payable for each day, or the 
proportionate amount for each part of a day, or such other rate as may be, as needed, established by the Ministry of Finance taking into account the circumstances.

2- Misrepresentation

Providing information about quality, quantity, value, or origin that is incomplete or inaccurate in violation of Article 45(1), 48(1), 64(1), 80, 83(1) Differences in quantity or value that are smaller than $5 \%$ of the quantity or value indicated in the declaration or other customs documents shall receive a written warning. If the customs duty is calculated according to the customs declaration and is $5 \%$ or more deficient than the actual amount, a fine shall be imposed as indicated below: - $5-15 \%$ deficiency - a fine equal to the deficiency, $-15-25 \%$ deficiency - a fine of two times the deficiency, $-25-40 \%$ deficiency - a fine of three times the deficiency, and - 40 - $60 \%$ deficiency - a fine of four times the deficiency $-60-80 \%$ deficiency - a fine of five times the deficiency - $80-100 \%$ deficiency - a fine of six times the deficiency 3 - In cases of understatement of quantity of more than $5 \%$, in addition to the fine, the undeclared goods shall be confiscated. In case of committing the violations in transit process, the above penalties shall be applied only if the violation is repeated after a written warning. In repetition of violation in other cases a fine of from one to two times the amount of the deficiency in the payment of the customs duty shall be paid provided that the person committing the offence has been given prior warning. 4- The penalties and warning provided in this Article may be waived by customs if it is proven that the misrepresentation was caused by a mistake of calculation or errors made in good faith during the preparation of the customs declaration.

(2) Class 2 Offences are as following: 1- a person who violates Articles 17, 46, and 48, and is provided a written warning of violation and an order to correct, and fails to comply with such written warning within the time required by Customs 2- A person who fails to comply with Articles 39 and 49(1) or fails to comply with the instructions of Customs concerning goods under customs supervision or control in violation of 34(5) and 49(2)

3 - A person who moves customs goods mentioned in Articles 34(5), 35, 38(1), 36, 80, 83, 123, and 132, from an authorized location to a non-authorized location.

(3) Class 3 Offences are:

1- Intentional misrepresentation of facts required to be submitted to customs for the purpose of benefiting from a more favorable customs tariff

2- Executions in violation of Articles 50(2), 61(2), 66, 134, and 135, with the intent to frustrate the enforcement of customs legislation

\section{Article 167 (Penalties)}


(1) Persons committing class 2 Offenses shall be punished by a fine of 10 to $50 \%$ of the value of goods, taking into account the condition provided for in Article 20, in accordance with guidelines of the General Directorate of Customs.

(2) Persons committing class 3 offenses shall be punished by a fine of 50 to $100 \%$ of the value of goods taking into account the conditions provide for in article 20, in accordance with the guidelines of the General Directorate of Customs.

(3) The payment of cash penalties under this Article does not negate the payment of the principle customs debt.

\section{Article 168 (Multiple Offenses)}

If a violator commits more than one administrative violations at the same time a separate fine will be applied for each violation.

\section{Article 169 ( method for Collection of Fines)}

cash fines and other proceeds authorized by this chapter shall be collected in accordance with relevant procedures.

Article 170 (Discretionary administrative penalties)

(1) Smuggling of goods of a value less than Afghanis 10,000 shall be dealt with as a Class 3 offense, unless aggravating circumstances are present.

(2) If the value of goods is in excess of Afghani 10,000, the Director General of Customs may settle the case administratively without referral to the justice authorities upon a request by the offender taking into account the simple circumstances and non aggravating circumstances, provided:

1- the judicial prosecution has not started; 2- the amount of the customs duty due on the goods involved in smuggling is less than Afghani 20,000; 3 - the offender pays the amount of the customs duties and fines 4- the offender agrees to give up their right of appeal referred to in Article 18.

5- the amount of 10,000 Afghani referred to in this paragraph may be changed by the Minister of Finance upon the approval of the Council of Ministers.

(3) The fine applicable to the customs offense described in Paragraph 2 can be from 1 to 3 times the penalty of a Class 3 offense in accordance with the guidelines of the General Directorate of Customs. If the offender accepts payment of the mentioned fines, there shall be non criminal charges brought against the offender.

Otherwise, Customs officials are obliged to refer the case to the competent authorities for prosecution.

(4) The seized goods and the violator shall be released from customs control immediately after the customs verify that all the conditions and obligations referred to in paragraphs 1 and 2 of this Article are fulfilled by the violator.

(5) This provisions of paragraphs $(1,2,3)$ and 4 shall not 
apply when:

1 - the act is committed by a customs employee, a customs broker, or any other person whose activity is connected to that of customs in any way

2- the violator possesses any smuggled or smuggling object as a consequence of another criminal act; or 3 - the goods are prohibited or restricted goods, as referred to in Article 53 (2)

4- the person is repeatedly a violator.

(6) Any Class 3 offense shall be referred directly to the competent authorities for prosecution if committed together with any of the conditions mentioned in paragraph 5 of this article.

(7) In cases where section (5) or (6) applies, the report mentioned in paragraph 1 Article 184 shall be attached to the decision of the customs regarding the fulfillment of the conditions mentioned in that article.

\section{Article171(License Revocation)}

The Ministry of Finance may revoke licenses granted pursuant to Articles 16, and 70 for repeated or serious violations of the conditions under which they are granted.

Article 172 (Smuggling of Goods)

(1) Carrying out the following activities is deemed to be smuggling and the offender shall be punished in accordance with this law and any other customs legislation :

1- Introduction of goods into the customs territory of the State, or the exit of goods, in violation of the provisions of this Law and other customs legislation, with the intent of avoiding (ejtinab) customs control or supervision.

2- To carry prohibited goods for the purpose of import, export, or storing without permission of the relevant authorities.

3- Selling or purchasing of goods in a transit process without paying customs duties

(2) carrying out the following activities repeatedly, or showing intent to carry out the following activities shall be considered smuggling:

1- Violate the conditions for use of goods that occasioned a partial or total relief from customs debt by reason of their end-use pursuant to Article 66.

2- possess goods against the provisions of article 61, paragraph 2 ;

3- remove or falsify the identification number of the means of transport;

4- purchase, sell, store, and possess imported goods with knowledge that they are smuggled goods; such knowledge will be presumed in the case of a warehouse keepers who stores imported goods without copies of the related customs declarations.

5- Break the seal or substitute or change other security verifications placed on the means of transport or goods. 6- Load, unload, or move goods, travelers or their luggage, 
from one means of transport to the other without permission from the customs, in an unauthorized place.

(3) Smuggling is considered to have been committed by the

Captain of an aircraft who:

1- transports goods without the relevant manifest, or with a manifest that misrepresents the goods on board;

2- has not presented goods to customs which were brought into the customs territory of the State according to the manifest but are not on board at the time of departure, 3- Lands out of a customs airport, and does not notify its landing to the customs or other relevant authorities within the shortest time.

\section{Article 173 (Sanctions Applicable to Smuggling)}

(1) The violators referred to article 172 shall be punished with:

1- Confiscation of the smuggled goods;

2- A fine from two to five times the amount equal to the applicable customs debt of the smuggled goods; and 3- Punishment in accordance with Article 179.

(2) In case of committing a violation by more than one person, each one shall be fined proportionate to that person's participation in the violation.

If one of the parties pays the full amount, the others are free of any obligation to Customs for the fine in question.

(3) When the same violator commits at the same time several violations referred to in chapter 14 , the violator shall be punished for each of the violations separately.

\section{Article 174 ( Smuggling Objects)}

(1) "Smuggling objects [means] any objects (wassaiel) involved directly in the act of smuggling, including arms, and the means of transport and other objects used to transfer or to hide smuggling goods. Smuggling objects will be seized by the customs and, upon decision of the competent courts may be confiscated and treated as abandoned goods. The means [objects] mentioned in paragraphs 3 and 4 are an exception to this rule.

(2) The seizure of smuggled goods will take place regardless of the amount and the degree in which the owner of the goods took part in the smuggling action.

(3) Where the person convicted of smuggling took possession of the seized objects as a consequence of a criminal act, the objects will be returned to the owner. (4) Means of transport are exempted from the seizure, whenever:

1- on the basis of evidence, the owner is not proven to be involved in the act of smuggling;

2- The owner provided the means of transport in good faith in the ordinary course of business. (Without knowledge of its use for smuggling or other illegal activities).

(5) The court, is obliged to take a decision ordering the confiscation of the means of transport and other objects of smuggling within 5 days of referral of the case. The transporting vehicle and other objects of smuggling shall be put 
up for auction in accordance with the order of court.

\section{Article 175 (Vehicles)}

The owner, or driver, of the vehicle transporting smuggled goods shall be punished as follows:

1 - If the owner of the vehicle carrying smuggled goods seized together with the vehicle and there is proof that the owner of the vehicle is aware of the existence of smuggled goods, the owner of the vehicle shall be sentenced to the punishment of a cash fine equal to the cost of the smuggled goods.

2- If the owner of the transporting vehicle commits the above crime repeatedly, the transporting vehicle shall be expropriated.

3- If it is proved that the driver of the transporting vehicle is aware that the goods he is transporting are smuggled, the driver shall be punished as an accomplice to the crime.

\section{Article 176 (The Seizure of Smuggling Objects)}

(1) Smuggled objects are seized in the following cases: 1 - the act of smuggling is being witnessed,

2 - the goods are in movement,

3- the goods are in an insecure public place, Except in the case where smuggling is witnessed, seizure of goods from private property shall take place only upon the prior order of the authorized court.

(2) The smuggled goods and the means thereof, when seized, shall be delivered promptly against receipt to the customs administration or to the district administration office in places where there are no customs organizations.

(3) In case of a dispute concerning prohibited or smuggled goods, the goods will be retained by Customs at the expense of the importer until the dispute is resolved, or turned over to the relevant authorities for legal action.

\section{Article 177 (Perishable Goods; Livestock.}

(1) The authorized courts, must issue an order regarding the auction of perishable goods (goods which very soon change in quality or spoil) livestock and other goods, the keeping of which requires expenses, promptly after seizure, but in no event later than 24 hours after seizure. (2) If the order of the court is not issued or reached in due time, custom authorities shall be responsible to sell the goods under the supervision of the of Customs with the agreement of the owner of the suspected goods, if present, and shall deposit the money in trust until receiving the order of the court.

\section{Article 178 (Compensation for Damages)}

No compensation for damages may be obtained that occurred during an act of seizure or confiscation of smuggled goods in the course of anti smuggling activities.

\section{Article 179 ( Range of Penalties)}


The committer, in addition to confiscation of the smuggled goods and the objects, shall be sentenced to imprisonment in the following conditions:

1- For one to three years imprisonment if the smuggled goods are allowed goods and cost more than Afghani $75,000$.

2- For six months to one year years imprisonment if the smuggled goods are banned goods and cost less than Afghani,20,000

3- For one to six years imprisonment if the smuggled goods are banned goods and cost more than Afghani, 20,000 .

\section{Article 180 (Aggravating Circumstances)}

(1) The maximum penalty included in article 179 of this law shall be imposed if the act of smuggling is committed with the help of two or more persons, or in case of repetition of the crime,

(2) If smuggling is committed through a network of smugglers the organizer of the network of perpetrators shall be penalized by an imprisonment of two times the punishments allowed by Article 179 .

(3) In cases where the smuggler shows armed resistance to the customs, whether injury results or not, the perpetrator shall be imprisoned for a period of 15 to 20 years.

(4) If the smuggler kills a customs official and / or other persons who assist them in their duties, the smuggler shall, in addition to the confiscation penalty, be sentenced to capital punishment. Accomplices in the killing shall be sentenced to a punishment of 10 to 15 years imprisonment.

Article181 (Participation of Government Employees in Smuggling Activity) Officials, military employees and other persons that are related in some way to the state, who participate in the organization and management of smuggling network shall be punished two and one - half times the punishment included in article 179 of this law.

Article 182 (Evaluation of Administrative Violations)

The evaluation (barrasi) of administrative violations shall be undertaken by two officials of customs assigned by the authority of the related customs administration .

\section{Article 183 (Authority for Access to Information) \\ In order to search for evidence of violations, Customs may be authorized in writing by the Director General of Customs to access commercial records and information records which are either maintained by Customs, or required by Customs to be maintained by others. Customs with a view to detecting and preventing administrative violations may carry out all necessary measures at offices, factories, warehouses and other locations and premises where accounts may be found or actions take place relating to customs affairs.}

Article 184 (Report and Collection of Evidence) 
(1) The written report of evaluation prepared and signed in triplicate, shall contain:

1- the place, the date and the time where the violation occurred

2- the names of the persons who sign the report and their position;

3- the name and address and other identifying information of those accused of a violation;

4- the classification of the violations mentioned in this law

5 - the location of the goods;

6- a description and identification of the means used to commit the violation;

7- the indication of the kind, quantity, quality, value, origin and tariff classification of the goods;

8- the amount of duty and other customs debt due;

9- the Articles of this law on the basis of which the proposed fines are assessed;

10- The signatures of the customs employees and that of the violator in accordance with article 170 .

(2) Customs must notify immediately the person or persons suspected of the violation about the registered report mentioned in paragraph 1 .

(3) Customs must conduct a hearing for violations of the Customs Law, collect documents and proofs, and record the declaration of witnesses. Customs will set a date and time and place for that purpose. The time limit for holding the hearing may not exceed 72 hours from the date of notification.

(4) The persons charged or witnessing the violation may be allowed by Customs to present and record their statement to the charges instead of being present at the hearing.

(5) The statements [and declarations] mentioned in paragraph 4 shall be signed by the persons charged with the violation and witnesses when they are present, and both the customs officers who preside over hearing.

(6) When any persons charged with the violation, or a witness, does not speak Dari or Pashtu, the hearing will be carried out in the presence of an interpreter who shall be responsible for the translation of the proceedings

\section{Article 185 (File Administration)}

Customs, after compiling the documents and reviewing the report concerning the administrative violation, shall sign and issue the decision disposing of the case.

\section{Article 186 (Appeal Against the Decision for Payment of a Fine)}

(1) A customs decision to impose a fine under this law has to be delivered and notified to the person accused within 24 hours from the time of the decision by customs officials.

(2) The person responsible for paying the fine may object to the decision of the customs imposing a fine in accordance with Article 18.

(3) In case of appeal in accordance with Article 18(4) the appellant must deposit, in addition to the customs debt deposited in accordance with Article 18(2) an amount 
equal to $40 \%$ of the total amount of the fine, provided that the total amount of the deposit shall not exceed the value of the goods subject of the violation.

(4) If the decision of the Customs Arbitration Administration is unacceptable to the appellant, the appellant shall deposit the remaining $60 \%$ of the fine prior to appealing from the opinion of the Customs Arbitration Administration which has been issued in accordance with article 18 .

(5) In accordance with articles 20 and 21 of this law, the deposit shall be returned within 5 days after any decision, customs opinion or order of court rendered in favor of the appellant becomes final.

\section{CHAPTER 15 DISTRIBUTION OF REVENUES AND GRANTING OF INCENTIVES}

\section{Article 187 (Distribution of Revenue from Fines and Expropriated Smuggled Goods)}

(1) Revenue from collection of fines and sale of smuggled goods shall be divided as follows: All revenues from fines to the State Budget. $50 \%$ of the value of confiscated goods to the State Budget, and $50 \%$ of the value of confiscated goods shall be distributed for incentives to customs police and personnel, informers and others who cooperated in accordance with this, Chapter, and to the improvement of the working conditions for the customs personnel.

(2) The proceeds from the auction of the confiscated smuggled goods are calculated and paid to the eligible persons after the final decision is given by the court, in accordance with the provisions of this Chapter

\section{ARTICLE 188 (Incentives for Informants)}

Individuals supplying reliable information in detecting smuggled goods shall receive the following incentives; 1 - To assigned informing persons- $5 \%$ of the value of he smuggled goods.

2- To non assigned informing persons $-7.5 \%$ of the value of the smuggled goods.

\footnotetext{
ARTICLE 189 (Incentives for Persons Seizing Goods)

Anyone personally seizing smuggled goods and dispatching them to the proper authorities shall receive the following incentives ;

1- In cases where the appointees seize smuggled goods from Places where Danger of accident is not probable, $10 \%$ of the Price of the smuggled goods.

In cases where there has existed danger of harm in dealing with the smuggler, but no murder or injury has resulted $-15 \%$ of the value of the smuggled goods except in the case of prohibited goods and drugs. These assignees are not entitled to take advantage of Article 188 of this law.

2- Other government officials and relatives not officially involved in The pursuit of smuggling or of the customs
} 
house officials who have assisted effectively with the relevant assignees $-2.5 \%$ of the price Of the seized

goods.

3- others who effectively aid the appointed official of smuggling $5 \%$ of the value of the seized goods.

4- Individuals killed during the seizure of smuggled goods

or who are injured such that their injury interferes with work or business shall be paid:

- To government employees - Afghani 500,000 -

$1,000,000$ in addition to receiving their retirement salaries and allotted incentives for themselves and their inheritors.

- To individuals not having retirement rights -Afghanis $800,000-1,500,000$ According to the degree of injury to themselves or to their inheritors in addition to the specified incentives.

5- If the informer or the seizer of the goods is more than one person, the incentives determined by Article 188 shall be divided between them equally.

\section{ARTICLE 190 (Halfed Incentives)}

If the owner of the seized goods is unknown or difficult to

locate the seizer of the smuggled goods and also his assistants shall receive one- half of the assigned incentives.

\section{CHAPTER 16 MISCELLANEOUS}

\section{ARTICLE191 (Assisting Customs Administrations)}

(1) Policing agencies in the Ministry of the Interior and other civil (mulki) and military institutions, are obliged to assist the customs in all aspects in its enforcement of this law and other customs legislation.

(2) Any person is bound to assist in the pursuit of persons accused of smuggling and in the seizure of smuggled goods, if those responsible for preventing smuggling seek help from that person.

(3) Any person can inform the appropriate authorities if they have knowledge of an attempt or act of smuggling. In this case, the identity of person shall be kept confidential by customs officials.

\footnotetext{
Article 192 (Presentation of Annual Customs Report) The Minsitry of Finance is obliged to prepare and present an Annual Report to the Council of Ministers. The report should include:

1- Annual operating budgets

2- The number of employees and their grades

3- Revenues collected by customs

4- Revenues forgone through evasion from payments or forgeries for getting duty relief.

5- Activities delegated to and from other agencies.

6- Other operating information that has impacted the work of Customs
} 


\section{Article 193 (Preferential Provisions)}

If any provisions from this law are in conflict with the provisions of any other legislation, the provisions of this law shall prevail.

\section{Article 194 (Date of Enforcement)}

1- Article 194 of this law shall be effective from the date of its endorsement (Tausheh) [by the Head of State] and shall be published in the Official Gazette. From the effective date of this law, the Customs Code published on 28 Saur 1361 (Official Gazette Number 508) and the Regulations Organizing Customs Affairs published on 15/1/1367 (Official Gazette 663) amendments or any other contrary provisions shall be nullified. 


\title{
LAW FOR SECURED TRANSACTION ON MOVABLE PROPERTY IN BANKING TRANSACTIONS
}

\author{
Chapter One \\ General Principal
}

\begin{abstract}
Necessity of Creation of Law
Article One:

This Law is created to regulate business and banking transactions that use Movable Property as security and specify the rights and obligations of the parties.
\end{abstract}

\author{
Purpose \\ Article Two: \\ The purpose of this law is: \\ 1- To secure Debt and create contracts using Movable Property. \\ 2- To pave the way for accessibility to negotiable banking credits by Securing \\ Movable Property. \\ 3- To provide mutual agreement between parties to a banking transaction. \\ 4- To have expansion of commerce and investment and upgrading national \\ economy.
}

\section{Definitions}

Article Three:

The following definitions shall apply in this Law:

1-"Debt" means the amount of money that debtor (Chargor) owed on an Account or to a Chargeholder in accordance with a Securing agreement. Debt may include the cost of Financing, penalties, damages, expenses and other related liabilities.

2-"Debtor" means a Person owing a Debt.

3-"Lender" means a Person having a right to receive payment of a Debt or performance under a Securing agreement.. A Lender may be incorporated within or outside Afghanistan and transact the business of banking as defined under the Law of Da Afghanistan Bank or the Law on Banking in Afghanistan.

4-“Execution creditor" means a Person who acquired court decree regarding secured charge in favour of himself.

5 "Securing agreement" means the written agreement between Chargor and Chargeholder for one or more transactions.

6- "Chargor" means a Person who owns Collateral and, in most cases, owes the Debt. When these are different Persons, the term Chargor means the owner of Collateral and Debtor means the one owing the Debt.

7- "Chargeholder" means a Person in whose favour a Securing charge is created. 8- "Collateral" means Movable Property charged to secure Debt. Collateral may be located within or outside Afghanistan and may include Proceeds collateral.

9-"Securing charge" means a right in Movable Property, whether present or future. It secures one or more Debts that arise before or after the Securing agreement is signed. 10-“Proceeds collateral" means money or a specific type of Movable Property that results directly or indirectly from the disposal of Collateral. The definition extends to later generation Proceeds from Collateral and to insurance payments for damaged or lost Collateral.

11--"Property" means possessions or things capable of ownership and includes Movable and Immovable Property.

12- "Movable Property" means tangible items that can be physically moved from one location to another without changes in shape and substance and includes tangible things such as Goods and intangible things such as Documents of title, Accounts, Securities, instruments, copyrights, trademarks and patents.

13- "Immovable Property" means tangible items that can not be moved from one location to another without change in shape and substance. Land, homes and buildings 
are Immovable Property.

14-“Goods" means tangible Movable Property. They include Movable things that are attached to other Immovable or Movable Property.

15-“Consumer Goods" means Goods used or acquired primarily for personal, family or household purposes.

16-"Inventory" means Goods held by a Person for sale or lease. It includes Goods that are to be furnished or have been furnished pursuant to a contract of service.

17- "Equipment" means Goods that are used for the purpose of operating a business which are neither Consumer Goods nor Inventory.

18-"Commingled Goods" means Goods that are physically united with other Goods in such a manner that their identity is lost in a product or unit.

19- "Account" means a monetary Debt that is not created based on a negotiable instrument or a Security, and the Debtor is obliged to pay it.

20- "Account Debtor" means a Person who owes, or will owe, a monetary Debt to another Person.

21-“Transferee" means a Person to whom a Transferor assigns a Securing agreement or an Account.

22-“Transferor" means a Person who assigns money that others owed him under a Securing agreement or an Account to a Transferee.

23-"Notice" means written information regarding the Collateral delivered to a Person's address, office headquarters or place where the Person resides or operates. Reasonable means of receipt is required.

24. "Registry" means an office that registers a secured transaction on Movable Property and its related documents and keeps the records.

25-"Notice of Registration" means a form prescribed by the procedures for Registration in the Central Charge Registry.

26- "Purchase money Securing charge" means a Securing charge on Goods taken or retained by a seller of the Goods to secure all or part of their purchase price. A Purchase money Securing charge:

i) includes a Securing charge taken by a Person other than the seller who, by providing Financing, gives value that allows the Chargor to acquire ownership of the Collateral;

ii) includes the right of a seller, lessor, or consignor in a transaction referred to in this Law;

iii) may include interest and charges for Financing payable to a Chargeholder.

27. "Default on Payment" means failure to pay a Debt or its instalment when due as stated in the Securing agreement.

28. "Default on Performance" means failure to perform an obligation stated in the

Securing agreement.

29- "Documents of title" means a written document prepared in accordance with the law that proves ownership or the right to possess Movable Property.

30-"Security" means a negotiable financial instrument.

31-"Person" means a natural or juridical person.

32-"Finance" or "Financing" means and includes the amount of Debt and costs that

arise from the following:

i) an accommodation or facility provided on the basis of participation in profit

and loss, mark-up or mark-down in price, hire, purchase, equity support, lease, rent-sharing, licensing, charge or fee of any kind, purchase and sale of any

Movable Property including commodities, patents, designs, trade mark, and copy rights, bill of exchange, promissory notes or other instruments with or without buy back arrangement by a seller, and participation in morabah, musawama, istisnah or modaraba terms of Financing;

ii) a credit card or charge card arrangement between a Lender and Debtor;

iii) a guarantee, letter of credit or any other financial commitment a Lender may provide on behalf of a Debtor or Chargor;

iv) a loan, an advance, overdraft, a bill of exchange that is discounted and 
purchased or any other financial accommodation provided by a Lender to a Chargor or a Debtor.

33-“Chargor's Location" means a Chargor principal place of business, if any, or his residence if there is no place of business. A corporation is located where it was incorporated.

\section{Scope of Application of the law on Transactions}

Article Four:

(1) This Law governs any transaction that creates a Securing charge on Movable Property.

(2) Provisions of this Law apply in the same way to the following transactions: 1- Contract to provide Finance;

2- Contract for the sale of Goods providing for reservation of title by the seller until payment of the purchase price and the fulfilment of any other obligation; 3- Transaction involving the sale of an Account;

4-Transaction involving transfer of possession of Goods or consignment of Movable Property from the owner (consignor) to another Person (consignee) for the purpose of sale, or

5- Lease of Goods having a term of more than one year.

(3) When Consumer Goods appear in a Securing agreement or any related agreement, a natural person can not waive or limit any rights or remedies provided in this Law. Any such waiver or limitation is not enforceable and cannot affect or decrease the value of the Securing agreement.

\section{Scope of Application of the law on Parties}

\section{Article Five:}

(1) The rules applicable to a Chargeholder in this Law apply in the same way to the following persons:

1-The Lender that provides Financing to a Debtor;

2-The seller under a contract for the sale of a Goods providing for reservation of title by the seller;

3- The buyer of an Account;

4-The consignor under a consignment agreement; or

5-The lessor under a lease of Goods having a term of more than one year.

(2) The rules applicable to a Chargor, apply in the same way to the following persons:

1- The owner of Collateral when the Collateral is used to secure Finance;

2- The buyer under a contract for the sale of Goods providing for reservation of title by the seller;

3- The seller of an Account;

4- The consignee under a consignment agreement; or

5- The lessee under a lease of Goods having a term of more than one year.

\section{Securing charges}

\section{Article Six:}

The Movable Properties which can be a charge are as follows:

1- A monetary obligation or one capable of being valued in money.

2- A Debt may be that of the owner of the Movable Property or the Debt of another Person.

\section{Chapter Two \\ Effects and creation of Securing charge}

\section{Creation of a Securing charge}

Article Seven:

A Securing charge attaches to Collateral and becomes enforceable against the Chargor 
only when the following conditions are met:

1- The Chargor and the Chargeholder sign a written Securing agreement that describes the Debt and the Collateral

2- The Chargor is:

- the owner of the Collateral, or his authorize agent;

- a buyer in a contract for a sale of Goods with right of ownership;

- the seller of Accounts;

- the consignee; or

- a lessee under a contract for a lease of Goods having a term of more than

one year; and

3- The Chargeholder is bound through a contract with the Chargor to provide Finance to the Chargor, or to another Person, or perform any other act for or at the request of the Chargor, or, prior to execution of the Securing agreement; the Chargeholder advanced money or provided Finance to or at the request of the Chargor.

\section{Securing agreement}

Article Eight:

(1) A Securing agreement may relate to more than one Securing charge and need not be evidenced by a single document.

(2) The Collateral will be described reasonably. This may refer to kinds of Movable Property to be acquired by the Chargor in the future.

(3) A description of the Debt is sufficient if it reasonably identifies the amount and date of payment.

\section{Timing of a Security Charge \\ Article Nine:}

(1) The Securing charge on Collateral arises when the Chargor acquires ownership of the Collateral and signs the Securing agreement.

(2) The Securing charge on Collateral arises when the Chargor receives possession of the Goods and is one of the following persons:

1- Buyer of Goods (where the seller maintains reservation of title)

2- Consignee

3- Lessee of Goods for a term of more than one year.

(3) When the Chargor is the Transferor of an Account, the Securing charge arises when the Account was created.

\section{Rights and Duties of a Chargeholder who possessed the collateral Article Ten:}

A Chargeholder has the following rights and duties

(1) The Chargeholder shall use reasonable care in the custody and preservation of Collateral in his possession.

(2) Any necessary expenses and legal obligations incurred by the Chargeholder, which are related to the protection of the Collateral, are obligations of the Chargor and considered part of the Securing charge against the Collateral.

(3) Unless otherwise agreed by the parties, the Chargeholder may hold as additional Collateral any increase in value or profits received from the Collateral.

\section{The Right to Request Information Article Eleven:}

(1) A Chargor, an Execution creditor or a Chargeholder with a Securing charge on the Chargor's Movable Property has the right to request that:

1- The Chargeholder approve or correct a list of the Collateral;

2- The Chargeholder approve or correct a statement indicating what the Chargeholder believes to be the aggregate amount of unpaid Debt as of a specified date, or 
3- The Chargor be given a copy of the Securing agreement.

(2) The Chargeholder will comply with clause (1) of this Article within 14 days of receipt of the request or is subject to the penalties outlined in the procedures.

\section{Chapter Three \\ Effect of a Securing charge against Third Parties}

\section{Completion of a Securing charge Article Twelve:}

(1) A Securing charge is completed when it has attached to the Collateral as provided in Article (7) of this Law and one of the following requirements is met:

1- The Securing charge is registered as provided in this Law

2- The Chargeholder, or agent of the Chargeholder who is not the Chargor, has taken physical possession of the Collateral pursuant to a Securing agreement 3- A provision of this Law states that the Securing charge is completed.

(2) If a Securing charge is originally completed pursuant to the law and is again completed in accordance with this Law, without a lapse of more than 180 days, such Securing charge is considered to have been completed continuously.

(3) When there is a Securing charge on Goods in the possession of bailee, the bailee issues a Document of title under the name of the Chargeholder, or the bailee agrees to keep the Goods on behalf of the Chargeholder.

\section{Temporary Completion and Collateral Returned to the Chargor Article Thirteen:}

(1) A Securing charge on an instrument or a Security that was completed by possession with the Chargeholder or his agent, remains completed without the need for Registration for 20 days after the Collateral comes under the control of the Chargor for the purpose of sale, exchange, presentation, collection, Registration or transfer.

(2) A Securing charge in Goods that was completed by following manners, remains completed without the need for Registration for 20 days after the Goods come under the control of the Chargor for the purpose of sale, exchange, handling or any dealing in a manner preliminary to their sale or exchange.

1- Possession of the Chargeholder

2- Issuance of a document of title in the name of the Chargeholder

3- Possession by a Person who has agreed to keep the Goods on behalf of the Chargeholder.

(3) After expiration of period stated in clause (2) of this Article the Securing charge ceases to be complete unless the Chargeholder reinstates the Securing charge by one of the methods provided in this Law.

(4) A buyer or lessee who buys or leases the Collateral during the 20 day period described in this Article takes free from the Securing charge if he had no

Knowledge of this charge at the time of such sale or lease.

\section{Effect, Continuity and Proceeds of Collateral Article Fourteen:}

(1) When an Account is subject to a Securing charge, the Chargeholder has the same rights against a guarantor of the Account as that of the Chargor.

(2) Except as otherwise provided in this Law, a Securing charge continues in the Collateral after its disposal. Disposal includes the sale, lease, license, exchange or other means unless the Chargeholder authorized such disposal free of the Securing charge.

(3) Following disposal of Collateral, a Securing charge attaches to the receipt of money, other identifiable Movable Property and insurance Proceeds paid after damage or loss to the Collateral (Proceeds collateral).

(4) The completion and priority of a Securing charge on Proceeds collateral are the 
same as the completion and priority of the Securing charge on the original Collateral if:

1- Registration of the original Securing charge on the Collateral included a description of Proceeds collateral;

2- Proceeds collateral is the same type of Movable Property as the original

Collateral;

3- Proceeds collateral is money, a cheque or a deposit with a financial institution.

\section{Priority between securing charges \\ Article Fifteen:}

(1) A Chargor may grant more than one Securing charge over the same Collateral.

(2) Priority is determined as below, unless otherwise anticipated by other laws.

1-A completed Securing charge has priority over an incomplete Securing charge.

Priority among incomplete Securing charges is determined on the basis of the first Securing charge to attach to the Collateral.

2-Priority between two or more completed Securing charges is determined on the basis of the order in which the Chargeholders registered their Securing charges, took possession of the Collateral, or the Securing charges were otherwise completed.

3-A Purchase money Securing charge on Inventory, or its Proceeds collateral, has priority over another Securing charge on the same Inventory if it is completed and the Chargeholder with the Purchase money Securing charge notifies the earlier Chargeholder by the time the Chargor obtains possession of the Inventory. The notification must state that the Person giving the notification has, or expects to take, a Securing charge on the Inventory and must contain a description by item or type.

4- A Purchase money Securing charge on the following terms has priority over any other Securing charge on the same Collateral given by the Chargor.

- Collateral or its Proceeds collateral, other than intangibles or Inventory, that is completed not later than 20 days after the day on which the Chargor, or another Person at the request of the Chargor, obtains possession of the Collateral

- An intangible or its Proceeds collateral that is completed not later than 20 days after the day on which the Securing charge on the intangible attaches

(3) When a Registration has lapsed, or has been discharged either in error or without authorization by the Chargeholder, and the Chargeholder transmits to the Registry

a Notice of reinstatement not later than 30 days after such lapse or discharge, such lapse or discharge does not affect the priority of the Securing charge in relation to competing Securing charges that, prior to the lapse or discharge, had a lower priority.

\section{Priorities over Incomplete Securing charges Article Sixteen:}

(1) If the Securing charge is not completed, a claim of an Execution creditor has priority over such charge if:

1- The chargholder has not registered a Registration Notice before the creditor becomes an Execution creditor; or

2- The Chargeholder had Knowledge of the existence of the Execution creditor. (2) The right of the buyer of Collateral who bought it without Knowledge of an incomplete Securing charge, and before it is completed, has priority over such charge.

(3) The right of the lessee of Collateral that took possession without Knowledge of a Securing charge, and before such Securing charge is completed, has priority over such charge. 


\section{Priority of Securing Charges and Future Advances Article Seventeen:}

(1) The priority of a Securing charge extends to all money advanced for Financing, present or future, under the Securing agreement or a related agreement.

(2) A completed Securing charge does not have priority over the rights of an Execution creditor after the Chargeholder had Knowledge of the Execution creditor, when:

1- The money is advanced to someone other than the Chargor;

2- The Chargeholder has incurred reasonable expenses for the preservation, maintenance or repair of the Collateral.

(3) The Chargeholder is not required to advance money to Finance the Chargor if the Collateral is seized and restrained by the order of the Court.

\section{Rights of Buyers and Lessees of Collateral Article Eighteen:}

(1) A buyer that pays reasonable value for Goods sold in the ordinary course of the seller's business takes free of a complete or incomplete Securing charge on the Goods, even if the buyer has Knowledge of the Securing charge.

(2) A lessee that pays reasonable value for Goods leased in the ordinary course of the lessor's business takes free of a complete or incomplete Securing charge on the Goods, even if the lessee has Knowledge of the Securing charge.

(3) Any buyer and lessee takes free of any Securing charge on Goods for purchases or leases under Afs 5,000.

(4) A buyer or lessee of Goods to be used for farming purposes who buys or leases such Goods without Knowledge of a Securing charge take free of a complete or incomplete Securing charge if the purchase price of the Goods or, in the case of a lease, the market value of the leased Goods, does not exceed Afs 50,000.

\section{Preferences of Claims from Service Providers \\ Article Nineteen:}

If a Person in the ordinary course of his business furnishes services or materials with respect to Collateral, a right in such Collateral exists up to the value of such materials or services that has priority over any complete or incomplete Securing charge.

\section{Priorities among Securing charges Attached to Immovable Property Article Twenty:}

(1) A Securing charge on crops or Movable Property attached, or intended to become attached to Immovable Property have the rights and priorities provided in this Law to the extent that they do not conflict with provisions of law for Mortgages on Immovable Property.

(2) A Securing charge on crops or Movable Property attached to Immovable Property has priority over the rights of the owner of the Immovable Property at the time the crop is planted, or at the time Movable Property is attached to Immovable Property. This same Securing charge, if completed, has priority over the rights of an Execution creditor or a Person who later acquires ownership or takes a mortgage on the Immovable Property.

(3) Upon Default on Payment or Default on Performance a Chargeholder who has priority under this Article may remove the crops or Movable Property from the Immovable Property.

\section{Securing charges on Goods Attached to Movable Property Article Twenty One:}

(1) Accession occurs when Goods are attached to other Goods in such a manner that they have not lost their separate identity and can be separated without substantial expense or without causing substantial damage. A Securing charge on Goods continues after accession occurs. 
(2) If a Securing charge is completed after accession occurs, it remains completed and has priority over the rights of:

1- The owner of Goods to which the accession attached;

2- An Execution creditor, and

3- A Person who later acquires ownership or becomes a Chargeholder of the

Goods.

(3) Upon Default and subject to the provision of Chapter 5 of this law, a

Chargeholder who has priority under this article may remove his Movable

Collateral from Goods after accession occurs.

\section{Priority of Securing charges on Commingled Goods}

Article Twenty Two:

(1) A Securing charge may not be created in commingled goods except that, if

Collateral becomes part of commingled Goods, any Securing charge on the original Collateral attaches to the product. The Chargeholder may enforce his Securing charge on the product only to the extent of the value of the original Collateral, before it became part of commingled Goods.

(2) If more than one Securing charge attaches to a product, a completed Securing charge has priority over one deemed an incomplete Securing charge at the time the Collateral became part of commingled Goods.

(3) When there is more than one completed Securing charge on the product, the Securing charges rank equally in proportion to the value of the Collateral at the time the Goods were commingled.

\section{Preference Relating to Instruments, Securities and other Items Article Twenty Three:}

(1) A Securing charge over an instrument acquired by a Person in a manner provided under the Law of Banking in Afghanistan takes priority over a completed Securing charge.

(2) A Person that buys a Security, or has a Securing charge on such Security, has priority over a completed Securing charge if this Person acquired the Security or Securing charge for value.

(3) A Transferee who obtains a Document of title has priority over the other's Securing charge on Goods contained in the Document of title if:

1- Transferee gives value for and takes possession of the Document of title without Knowledge of the Securing charge.

2- The transfer is completed according to the requirements contained in the Document of title.

(4) A possessor of money has priority over a Securing charge given on the money if the possessor acquired the money without Knowledge of the Securing charge.

When the possessor gives valuable Property or assumed an obligation in exchange for the money, the possessor has priority whether or not he had Knowledge of the Securing charge.

(5) A creditor who receives money toward payment of a Debt has priority over a Securing charge on the money paid on this Debt. This applies whether or not:

- The creditor had Knowledge of the Securing charge at the time of payment,

- The payment was made through the use of an instrument, a Security, an electronic funds transfer, a manual funds transfer, a debit or a similar mode of payment.

\section{Subordination agreement Article Twenty Four:}

A Person with a Securing charge that has priority under this Law may agree to modify or forego his priority in favour of other Chargholders. This is referred to as a subordination agreement. A subordination agreement must be in writing and recorded in the Registry. 


\section{Chapter Four \\ Transfers}

Transferring Responsibilities of Chargor and Debtor Article Twenty Five:

(1) Unless otherwise stated in this Law, the rights and responsibilities of a Chargor and Debtor in a Securing agreement and regarding a Debt can be transferred to another Person after consent of the Chargeholder.

(2) The existence of a Securing charge or permission for the Chargor to dispose, use or transfer Collateral does not, by itself, impose liability upon a Chargeholder for the acts or omissions of the Chargor.

\section{Rights of Transferring Responsibilities of Chargholder Article Twenty Six:}

(1) A Chargeholder may transfer his right to receive payments on a Debt, along with related Collateral, to a Transferee without permission of the Account Debtor.

(2) A transfer is enforceable upon written Notice to the Account Debtor. Notice is not required for creation, attachment or completion of a Securing charge on an

Account.

(3) A transfer is not allowed if:

1- The Chargeholder had agreed in writing to forego transfer

2- The transfer is inconsistent with the law

3- It imposes undue hardship on the family of the Account Debtor following his death or disability

4- The Debt can not be distinguished from other Debts in the possession of the proposed Transferee.

Rights and Responsibilities of a Transferee Article Twenty Seven:

(1) Unless otherwise stated in the Securing agreement, the rights of a Transferee against the Account Debtor are subject to:

1- All the terms of the Securing agreement or any related agreement between the

Transferor and the Account Debtor, and

2- Any other defense or claim of the Account Debtor against the Transferor, which accrues before the Account Debtor receives a written Notice of transfer .

(2) Claims of an Account Debtor may be asserted against the Transferee under this article only to reduce the amount of the Accounts.

(3) Modification or substitution of a contract between the Transferor and the Account Debtor is effective against a Transferee if it is made in good faith and is in accordance with reasonable commercial standards.

\section{Account Debtor's duty}

\section{Article Twenty Eight:}

(1) An Account Debtor may discharge its Debt by paying the Transferor before he receives a notification that the amount due has been transferred to the Transferee. After receipt of such notification, the Account Debtor can only discharge its Debt by paying the Transferee. A notification is effective if it reasonably identifies the Accounts transferred.

(2) If requested by the Account Debtor, the Transferee must furnish within a reasonable period of time proof that the transfer was made. In the case that transferee refuse to presence such proofs, the Account Debtor is discharged from its obligation to pay the Transferee, even if the Account Debtor has received a notification.

(3) An Account Debtor that has received notification of a transfer is entitled to a release from any further obligation to the Transferor, provided that there is no outstanding charge and Transferor has no commitment to provide more Financing 
or incur an obligation.

The release shall be sent within three business days after the Transferor receives a request from the Account Debtor.

\section{Chapter Five \\ Effects of Default on Payment or Default on Performances}

\section{Measures on Default of Payment or Default on Performances \\ Article Twenty Nine:}

(1) Upon Default on Payment or performance, the Chargeholder may:

1- Give written Notice of the Default to the Chargor and upon such Notice, the

Chargor must pay or perform within 30 business days, unless otherwise stated

in the Securing agreement.

2- Enforce its rights against the Collateral as provided in the Securing agreement.

(2) The Chargeholder may apply to the court for compulsory enforcement in the case of Default on Payment by Debtor.

(3) All rights, duties and obligations arising from a Securing agreement, must be exercised and performed in a commercially reasonable manner.

\section{Collection of an Account, Instrument and Security Article Thirty :}

(1) After a Default and Notice of Default, the Chargeholder may inform any Person owing money to the Chargor pursuant to an Account, an instrument or a Security to pay such money directly to the Chargeholder.

(2) The Chargeholder may request the court to allow such action after Notice but without waiting the period stated in Article 29.

(3) Any costs or expenses incurred while enforcing clause (1or 2) of this Article shall be paid from the funds recovered to the Chargeholder.

\section{Enforcement upon Default on Payment or Default on Performance Article Thirty One:}

(1) Unless otherwise agreed, a Chargeholder may enforce the Securing agreement upon Chargor's Default and after Notice of Default by:

1- Taking possession of the Collateral according to the provisions of this Law;

2- Rendering Collateral, such as Equipment, unusable in a reasonable manner without removal from its location whereupon the Chargeholder is considered to have taken possession of such Collateral; and

3 - Disposing of the Collateral on the premises of the Debtor or Chargor in accordance with this Law.

(2) Special protection is provided for natural Persons that repay two-thirds of Debt for Consumer Goods subject to a Purchase money Securing charge. In such cases, any provision in a Securing agreement, or any related agreement, under which the Chargeholder may upon Default take possession of, or resell, the Consumer Goods is not enforceable under this Law unless:

1- The Chargor voluntarily allows possession by the Chargeholder,

2- Permission of the court is granted.

\section{Disposal of Collateral \\ Article Thirty Two:}

Upon Default under a Securing agreement, the Chargeholder may dispose of some or all of the Collateral before or after any commercially reasonable repair, processing or preparation. Proceeds from such disposal shall be applied in the following order: (1) To pay reasonable expenses of the Chargeholder, including cost of insurance, payment of taxes and any costs incurred in taking, holding, repairing, processing or preparing the Collateral for disposal. Other expenses may include those stated in the Securing agreement; 
(2) To pay the Debt covered by the Securing agreement;

(3) To pay any surplus funds to other Chargholders in order of priority; and

(4) To pay any remaining funds form clause (3) to the Chargor.

\section{Method of Disposal and it's Effects. \\ Article Thirty Three:}

(1) Any or all of the Collateral may be disposed of by:

1-Public sale, private sale, lease or otherwise, subject to provision of this law, and may take place at any time or place and on any terms that are considered

commercially reasonable; or

2-Purchase by the Chargeholder at a public sale for a purchase price considered at or near the commercial value of the Collateral purchased.

(2) Disposal of Collateral in accordance with this law terminates the Chargeholder's Securing charge, any subordinate Securing charge and the Chargor's interest in the Collateral.

(3) Any person that is liable to a Chargeholder under a guarantee, endorsement or similar agreement, and pays the Debt, and receives a transfer of Collateral from the Chargeholder, will succeed to the rights and duties of the Chargeholder. Such a transfer is not considered a disposal of Collateral.

\section{Seizure and Disposal of Collateral on Premises Article thirty Four:}

(1) When the Collateral is of a kind that cannot readily be moved from the premises of Debtor or Chargor, or is of a kind for which adequate storage facilities are not readily available, the Collateral may be seized without removing it from it's place.

(2) The Chargeholder must not sell the Collateral from the premises if this causes a major hardship to the Debtor or Chargor, or requires costs that are more than is necessary for the disposal.

(3) The Collateral may be sold by the Chargeholder in its exiting condition or after repair by the Chargeholder. Proceeds from such disposal shall be applied in the following order:

1-To pay reasonable expenses of the Chargeholder, including cost of insurance, payment of taxes and any costs incurred in taking, holding, repairing, processing or preparing the Collateral for disposal. Other expenses may include those stated in the Securing agreement;

2-To pay the Debt covered by the Securing agreement;

3-To pay other Chargeholders in order of priority that were duly notified of the disposal and responded to such Notice; and

4-To pay any remained funds to the Chargor.

\section{Notice of Disposal}

\section{Article thirty five:}

The Chargeholder shall give Notice of disposal not less than fifteen (15) days prior to disposal of the Collateral to the Chargor and to any other Chargeholder registered in the Registry. Such Notice shall include:

(1) A description of the Collateral;

(2) The unpaid amount of the Debt secured under the Securing agreement;

(3) The amount of costs and expenses or, where this amount has not been

determined, a reasonable estimate;

(4) A statement that, on payment of the total unpaid amount in (2) and (3) above, a Person entitled to receive Notice may redeem the Collateral;

(5) A statement that, unless the Collateral is redeemed by a person entitled to Notice, it is subject to disposal and the Debtor and/or Chargor may be liable for the total unpaid amount of the Debt not recovered from the disposal; and

(6) The day, time and place of any sale by public auction, the place to which closed 
tenders may be delivered, and the day after which closed tenders will not be accepted, or the date of any other disposal of the Collateral.

\section{Notice not required \\ Article thirty six:}

Notice of disposal is not required when:

(1) The Chargeholder has reason to believe that the Collateral consists of perishable items or will decline substantially in value if not disposed of immediately;

(2) The cost of care and storage of the Collateral is disproportionately large in

relation to its value; or

(3) After Default, each Person entitled to receive Notice consents in writing to

disposal of the Collateral.

\section{Report after Disposal \\ Article Thirty Seven:}

The Chargeholder shall give a written accounting of all the following information to the Chargor and other Chargeholders not later than seven (7) business days after receipt of a written request:

(a) The amount received from the disposal of Collateral;

(b) The amount applied to costs and expenses;

(c) The amount applied to the Debt; and

(d) The amount of any surplus and how it was distributed.

\section{Notice for Retaining Collateral Article Thirty Eight:}

(1) After Default on Payment or Default on Performance, the Chargeholder may propose taking possession of the Collateral, or a portion of it, in satisfaction of all or a part of the Debt secured by the Securing agreement. The Chargeholder must give Notice of this proposal to:

(a) The Chargor; and

(b) Any Chargeholders who, prior to the day on which such Notice is given to the Chargor are registered in the Registry.

(2) Any Person entitled to Notice according to the clause (1) of this Article may object within 15 (fifteen) days after receiving Notice from the Chargeholder. (3) If no Notice of objection is given during the term stated in clause (2) of this Article, the Chargeholder is considered to have irrevocably elected to take the Collateral in satisfaction of the Debt and is entitled to hold or dispose of such Collateral free of any rights of the Chargor or any other Chargeholder who was given a Notice.

\section{The Right of the Chargor to Redeem the Collateral Article Thirty Nine:}

(1) At any time before the Chargeholder has disposed or contracted for disposal of the Collateral, or before the Chargeholder is deemed to have irrevocably elected to retain the Collateral, the Chargor or any other Chargeholder may redeem the Collateral by paying all unpaid Debt to the Chargeholder. If applicable, the Chargor or other Chargeholder must also pay the Chargeholder reasonable expenses for seizing, holding, repairing, and preparing the Collateral for disposal.

(2) The Chargor may provide a written waiver of his right to redeem Collateral after Default on Payment or Default on Performance.

\section{Protection of Buyers of Collateral}

\section{Article Forty:}

When a Chargeholder disposes of Collateral to a buyer for value, such buyer acquires the Collateral free from the Chargor's rights and any claims by subordinate 
Chargeholders.

Exclusions in Enforcement of Provisions of this Chapter

Article Forty One:

Provision of this Chapter is not enforceable against consignment and leasing transactions.

\section{Chapter Six \\ Role of the Court and Rights of Protection}

\section{Request to the Court for Possession or Disposal \\ Article Forty Two:}

(1) If the Chargeholder elects to take possession of Collateral or dispose of such Collateral, he may request in writing that the court order enforcement. The court may rule on the Chargeholder's request by the following manner, within 15

days:

1- Deliver Collateral to the Chargeholder, or his agent, for disposal;

2- Dispose of the Collateral;

3- Require Persons to pay fees and expenses as provided in the related procedures, or

4-Otherwise take control of the Collateral.

(2) Neither the court nor the police officer as directed by the court is required to give prior Notice to proceeding with clause (1) of this Article.

(3) A third party who has rights to the Collateral and is affected by seizure or disposal of the Collateral may apply to the court to:

1 - Stop proceedings on a basis in fact that a Default has not occurred;

2 - Temporarily or permanently suspend the court decree if the Chargeholder has not complied with this Law; or

3 - Amend the distribution of money from the disposal of Collateral, within 30 days after distribution.

(4) The court will rule on application referred to in clause (3) of this Article within 15 (fifteen) days from the date the application is filed with the court.

\section{Chapter Seven \\ Miscellaneous Decrees}

\section{Exclusions}

Article Forty Three:

This Law does not apply to:

1-A transfer of a claim for compensation of an employee;

2- A sale of Accounts as part of a sale of the business out of which they arose;

3- A transfer of a right to payment under a contract to a Transferee that is also obliged to perform under the contract;

4- A transfer of a right to payment under a mortgage on Immovable Property or payments made under a lease of Immovable Property;

5-A transfer of Accounts made solely to facilitate the collection of Accounts for the Transferor;

6- A transfer of a right represented by a court decree, other than one taken on payment of Debt that was subject to a Securing charge under this Law, or 7- A transaction subject to other laws of Afghanistan or international convention or treaty that Afghanistan joined with.

\section{Registration of securing charge:}

Article forty four:

(1) Securing charges will be valid only when recorded and registered in the related Registry.

(2) Any amendment, cancellation and transmission on Securing Charge can be 
register in the Registry by Chargor and Chargholder.

\section{Settlement of disputes}

Article forty five:

Claims and disputes regarding priority of Securing charge and remedies will be resolved by authorized court.

\section{Application of the Law \\ Article forty six:}

(1) The validity, completion, and priority of a Securing charge on the following cases is governed by the law where the Chargor is located when the Securing charge is completed.

1- An Account, instrument, a Security or money completed by Registration, or 2- A motor vehicle that is not Consumer Goods, an aircraft, or railway car that is not Inventory.

(2) The validity, completion, and priority of a Securing charge on the following cases are governed by the law where the Collateral is located when the Securing charge is completed:

1- A motor vehicle that is Consumer Goods;

2- An instrument, Security or money when the Instrument, Security or money is in possession of the Chargeholder, or

3- Goods which are not referred to in clause (1) of this Article.

(3) This Law does not apply to a transaction executed before the effective date of this Law.

\section{Securing charge on Imported Goods \\ Article Forty Seven:}

When Collateral is Goods taken from another country, a Securing charge continues to be completed in Afghanistan if it is completed in Afghanistan not later than thirty (30) days after the date on which the Collateral entered Afghanistan. A buyer or lessee of the Collateral takes free from the Securing charge if the sale or lease occurs before the Securing charge is completed in Afghanistan.

\section{Creation of Procedures}

Article Forty Eight:

For the purpose of better implementation of the provisions of this Law, Da Afghanistan Bank may establish appropriate procedures and regulations.

\section{Priority between Provisions \\ Article fFty Nine:}

If any other provisions of law conflict with provisions contained in this Law, the provision of this Law shall be preferred.

\section{Effective Date}

Article Fifty:

This Law shall enter into force when signed and shall be published in the Official Gazette as of the effective date 


\title{
LAW OF DA AFGHANISTAN BANK Selected Provisions
}

\section{Chapter I ESTABLISHMENT, OBJECTIVES AND TASKS}

\author{
Article 1. Definitions \\ Wherever used in this Law, the following terms shall have the following meanings: \\ "Afghanistan" means the Islamic State of Afghanistan; \\ "bank" means a person engaging in the business of receiving money deposits or \\ other repayable funds from the public for the purpose of making credits or investments \\ for his own account; \\ "check cashing" means receiving compensation for taking payment instruments or \\ stored value, other than traveler's checks, in exchange for money, payment instruments, \\ or stored value delivered to the person delivering the payment instrument or stored value; \\ "commodity" means a currency, metal, agricultural product, basket of \\ commodities, and any other asset declared to be a commodity by regulation of the \\ Minister of Finance of Afghanistan; \\ "currency exchange" means receipt of revenues from the exchange of money of \\ one country for money of another country; \\ "DecreeBanking Law" means the law of Afghanistan approved by Decree Nr. \\ of the President of Afghanistan dated 24/ 6/1382; \\ "debt security" means any negotiable instrument of indebtedness and any other \\ instrument equivalent to such instrument of indebtedness, whether certificated or in bookentry form; \\ "derivative" means any negotiable forward contract, futures contract, option \\ contract and other contractual instrument that entitles its holder: \\ a. to acquire a security or a commodity, or a basket of securities or \\ commodities; or \\ b. to receive a cash amount determined by reference to a future price or value \\ of a security or a commodity, or by reference to a future price or value of a \\ basket of securities or commodities; or \\ c. to receive a cash amount determined by reference to an interest rate or \\ yield or a foreign exchange rate or an index of prices or values of interest \\ rates or yields, foreign exchange rates, securities or commodities; \\ "financial market" means any financial market or exchange where securities are \\ traded and the activities connected with such market or exchange; \\ "foreign currency" and "foreign exchange" mean: \\ a. the money of a country other than Afghanistan, \\ b. a monetary unit of account which is established by an intergovernmental \\ organization or by agreement between two or more countries, \\ c. gold if sold as bullion or specie, not including a significant increment of \\ workmanship, or \\ d. a combination of any of the things mentioned in a to c; \\ "Financial Services Tribunal" and "Tribunal" mean the Financial Services \\ Tribunal established by Article 108; \\ "foreign exchange dealer" means any person who engages in the business of \\ buying and selling foreign currencies, forward exchange contracts, options, swaps or \\ other derivative contracts involving a foreign currency, or arranging for payments in \\ foreign currency; \\ "forward contract" means a contract of sale for future delivery of a security or a \\ commodity; \\ "futures contract" means a forward contract with standardized terms and \\ conditions that is traded in a financial market; \\ "investment fund" means a company receiving funds from the public for \\ investment in securities; \\ "International Accounting Standards" means the most recent international
}


accounting standards issued by the International Accounting Standards Committee;

"monetary value" means a medium of exchange, whether or not redeemable in money;

"money" means a medium of exchange that is authorized or adopted by

Afghanistan or a foreign country; the term includes a monetary unit of account established by an

intergovernmental organization or by agreement between two or more countries;

"money service" means any service relating to money including safekeeping,

money transmission, check cashing, or currency exchange;

"money service provider" means any person who engages in the business of

providing a money service;

"money transmission" means selling or issuing payment instruments, stored value,

or receiving money or monetary value for transmission; the term does not include the

provision solely of delivery, online or telecommunications services, or network access;

"negotiable" with respect to a financial instrument means that the title to that instrument may be effectively

transferred by delivery of the instrument or by signed endorsement written on the instrument or by entry in

a register of owners of such instrument;

"option contract" means a contract that grants the holder of the contract the right

but not the obligation to buy (call) or to sell (put) a stated quantity of a security or

commodity against payment of an agreed price on or before a specified expiration date;

"payment instrument" means a check, draft, money order, traveler's check, or

other instrument for the transmission or payment of money or monetary value, whether or

not negotiable; the term does not include a credit card voucher, letter of credit, or

instrument that is redeemable by the issuer in goods or services;

"payment system" means any system or other arrangement (including

communication networks) between three or more money service providers for the processing of payments

or for the clearing or settlement of payment transactions, and for the exchange of payments against other

payments, financial obligations or securities, in any currency;

"payment system operator" means any person who operates a payment system;

"person" means any natural person, any legal person, any state and any political

subdivision, agency or instrumentality of a state;

"record" means information that is inscribed on a tangible medium or that is stored in an electronic or other medium and is retrievable in perceivable form;

"security" means a negotiable financial instrument (whether in the form of a

certificate or in book-entry form) of one of the following categories:

a. shares, or certificates or receipts in respect of shares;

b. debt securities, whether or not convertible into shares;

c. derivatives;

d. shares or participation units in investment funds;

e. any other negotiable financial instrument declared to be a security by regulation of $\mathrm{Da}$ Afghanistan Bank;

"securities service" means any of the services listed in Article 94 or declared to be

a securities service pursuant to Article 94;

"securities service provider" means any person who provides a securities service;

"securities transfer system" means any system or other arrangement (including

communication networks) between three or more securities service providers for the

transfer of securities, for the clearing or settlement of transactions in securities, and for

the exchange of securities against payments and other securities, in any currency;

"securities transfer system operator" means any person who operates a securities transfer system;

"share" means any share of capital stock or other equity security issued by a corporation;

"State" means the Islamic State of Afghanistan;

"State agency" means any administrative or political subdivision and any agency of Afghanistan, and any enterprise owned or effectively controlled by Afghanistan or by

any State agency; and

"stored value" means monetary value that is evidenced by an electronic record.

Article 2. Da Afghanistan Bank

1. Da Afghanistan Bank is the central bank of Afghanistan.

2. Da Afghanistan Bank is a juridical person with full capacity under the law of 
Afghanistan, and, in particular, the capacity to contract, to acquire and to dispose of movable and immovable property, to issue its own securities and otherwise to borrow, and to be a party to legal proceedings.

3. Da Afghanistan Bank shall have its head office in Kabul. Da Afghanistan Bank may establish and maintain branch offices, representative offices and liaison offices, and may appoint agents and correspondents, at such locations in Afghanistan or abroad and with such functions and duties as it shall determine.

\section{Article 3. Objectives and basic tasks of Da Afghanistan Bank}

1. The primary objective of Da Afghanistan Bank shall be to achieve and to maintain domestic price stability.

2. The other objectives of Da Afghanistan Bank, which shall be subordinated to the primary objective of Da Afghanistan Bank, shall be to foster the liquidity, solvency and proper functioning of a stable market based financial system, and to promote a safe, sound and efficient national payment system.

3. Without prejudice to its primary objective of domestic price stability, Da Afghanistan Bank shall support the general economic policies of the Government of Afghanistan, and to contribute to sustainable economic growth.

4. The basic tasks of Da Afghanistan Bank for which Da Afghanistan Bank shall be exclusively responsible are:

a. to formulate, adopt and execute the monetary policy of Afghanistan;

b. to formulate, adopt and execute the foreign exchange policy and exchange arrangements of Afghanistan;

c. to hold and manage the official foreign exchange reserves of Afghanistan;

d. to print and issue afghani banknotes and coins;

e. to act as banker and adviser to, and as fiscal agent of, the State;

f. to license or register and to regulate and supervise banks, foreign exchange dealers, money service providers, payment system operators, securities service providers, securities transfer system operators and such others as shall be submitted to its oversight by or pursuant to the law;

g. to establish, maintain and promote sound and efficient systems for payments, for transfers of securities issued by the State or Da Afghanistan Bank, and for the clearing and settlement of payment transactions and transactions in such securities.

\section{Article 4. Autonomous powers of Da Afghanistan Bank}

1. In carrying out its tasks, Da Afghanistan Bank shall enjoy autonomous regulatory powers and authority, including those to pass regulations to facilitate orderly electronic transactions between Da Afghanistan Bank and banks and their respective customers. All regulations, guidelines and instructions issued by Da Afghanistan Bank that apply to more than one institution shall be published in the [Official Gazette] and shall take effect on the date of such publication or on such later date as such regulation, guideline or instruction shall specify. Da Afghanistan Bank shall maintain a public register of such regulations, guidelines and instructions.

2. Da Afghanistan Bank shall be empowered to enter the offices and to examine the accounts, books, documents and other records of any bank, foreign exchange dealer, payment system operator, money service provider, securities service provider, securities transfer system operator or other person who is licensed by, or registered with, Da Afghanistan Bank, and to obtain such information from such person as Da Afghanistan Bank shall deem necessary or advisable for the proper discharge of its supervisory responsibilities.

3. When exercising the powers and carrying out the duties and tasks conferred upon it by law, Da Afghanistan Bank shall be entirely independent from any other authority in the pursuit of its objectives and the performance of its tasks. The autonomy of Da Afghanistan Bank shall be respected by all and no person shall seek to exercise improper influence on members of the decisionmaking bodies of Da Afghanistan Bank in the performance of their tasks or interfere in any other way in the activities of Da Afghanistan Bank.

4. Each member of the Supreme Council and the Executive Board and each other employee of Da Afghanistan Bank shall have the duty to promote the reputation of Da Afghanistan Bank as a politically autonomous central bank serving all of Afghanistan with impartiality, and shall refrain from any activity that is incompatible with that duty.

5. While serving in the supreme council, members of the supreme council of Da 
Afghanistan Bank shall not engage in political activities.

\section{Article 5. International cooperation}

1. Da Afghanistan Bank shall represent Afghanistan in all inter-governmental meetings, councils and organizations concerning monetary policy, licensing and supervision of banks and other persons submitted by law to its oversight, and the other matters that are within its competence.

2. Da Afghanistan Bank may provide banking services for the benefit of foreign governments, foreign central banks and monetary authorities, and for the benefit of international organizations in which it or Afghanistan participates.

3. Da Afghanistan Bank may participate in international organizations that pursue financial and economic stability through international monetary cooperation.

4. As agent of Afghanistan, Da Afghanistan Bank may undertake responsibilities and perform transactions concerning the participation of Afghanistan in international organizations. 


\title{
LAW OF BANKING IN AFGHANISTAN \\ Selected Provisions
}

\section{CHAPTER I GENERAL PROVISIONS}

\author{
Article 1. Principal definitions \\ Wherever used in this Law, the following terms shall have the following meanings: \\ "administrator" means any person who is a member of the Board of \\ Supervisors, the Management Board or the Audit Committee of a bank, and for any \\ office of a bank "administrator" shall mean any officer of the bank assigned to work at that office; \\ "Afghanistan" means the Islamic State of Afghanistan; \\ "bank" means a person engaging in the business of receiving money deposits or \\ other repayable funds from the public for the purpose of making credits or investments for his own account; \\ "bank holding company" means a company that is regulated by the bank \\ regulator of the country where it maintains its head office and that has one or more \\ subsidiaries with banking licenses; \\ "banking license" means an indefinite authorization issued by Da Afghanistan \\ Bank granting the right to a company to engage in the business of receiving money \\ deposits or other repayable funds from the public and extending credits or investments for its own account; \\ "banking activities" means the activities that are listed in Article 33; \\ "branch office" means a place of business forming a legally dependent part of a \\ bank where all or some banking activities are conducted; for the purposes of this \\ Decree Law, all domestic branch offices of a non-resident bank shall be treated as a \\ single branch office; all communications from Da Afghanistan Bank to any such branch \\ office may be validly made to the branch office notified by the non-resident bank to $\mathrm{Da}$ \\ Afghanistan Bank or failing such notification to a branch office selected by Da Afghanistan Bank; \\ "credit" means any disbursement or commitment to make a disbursement of a \\ sum of money in exchange for a promise to repay of the amount disbursed and to pay \\ interest or other charges on such amount, whether secured or unsecured; any extension \\ of the due date of a debt; any guarantee issued; and any purchase of a debt security or \\ other promise to pay sum of money and to pay interest either directly or by a \\ discounted purchase price; \\ "debt security" means any negotiable instrument of indebtedness and any other \\ instrument equivalent to such instrument of indebtedness, and any negotiable \\ instrument giving the right to acquire another negotiable debt security by subscription \\ or exchange; negotiable debt securities may be in certificated or in book-entry form; \\ "deposit" means a sum of money paid to a person and credited to a current \\ account or to a savings deposit account maintained with that person, terms under which \\ the deposit will be repaid or transferred to another account, with or without interest or a \\ premium, either on demand or at a time or in circumstances agreed by or on behalf of \\ the depositor and that person; \\ "domestic" when applied to a juridical person means a juridical person whose \\ head office is located in Afghanistan, and when applied to an office means an office \\ whose principal place of business is located in Afghanistan; \\ "dormant account" has the meaning given in Article 36; \\ "fit and proper person" means a person who may be regarded as honest and \\ trustworthy and whose professional qualifications, background and experience, \\ financial position, or business interests do not disqualify that person in the judgment of \\ Da Afghanistan Bank to be an owner, administrator or conservator of a bank; no person \\ shall be regarded as a fit and proper person if he has been convicted by a criminal court \\ of an offense for which he was or could have been sentenced to imprisonment without \\ the option of a fine unless such sentence was or would have been motivated by his \\ religious or political views or activities, or if he has been declared bankrupt by a court \\ of law, or if he, on grounds of personal misconduct unrelated to his religious or \\ political views or activities, has been disqualified or suspended by a competent
}


authority from practicing a profession;

"Da Afghanistan Bank" means the central bank of Afghanistan;

"Financial Services Tribunal" and "Tribunal" mean the Financial Services

Tribunal established by Article 108 of the Law for Da Afghanistan Bank;

"non-resident" when applied to a juridical person or office means a juridical

person or office that is not a domestic juridical person or office;

"person" means a natural person or a juridical person, or both;

"qualifying holding" means a direct or indirect holding in an undertaking which

represents 10 percent or more of the capital or the voting rights or which makes it

possible to exercise significant influence over the management of the undertaking in

which the holding subsists;

"representative office" means a place of business forming a legally dependent

part of a bank where no deposits or other repayable funds may be received from the public;

"subsidiary" means any juridical person in which another person or group of

persons acting in concert holds the equivalent of fifty percent or more of the voting

shares, or a qualifying holding that permits such other person or group of persons to

exercise effective control over the management or policies of the juridical person in

which the holding subsists.

\section{Article 2. Prohibited activities and sanctions}

1. No person shall engage in the business of receiving money deposits or other repayable funds from the public for the purpose of making credits or investments for his own account in Afghanistan without a banking license issued by Da Afghanistan Bank, other than a person listed in paragraph 2 .

2. The following persons shall be exempt from the requirements of this Law:

1) persons licensed and supervised pursuant to legislation of Afghanistan other than this Law to receive deposits or other repayable funds from the public for the purpose of making credits or investments for their own account in Afghanistan;

2) persons who fund the credits they make exclusively from non-repayable capital subscriptions and the proceeds of credits received from financial institutions or debt securities issued in the capital markets; and

3) persons who, by virtue of the nature or size of their business or the origin of their resources, are exempt by Da Afghanistan Bank from the requirements of this Law; exemptions so granted by Da Afghanistan Bank may be conditional or limited in time, or they may be partial and list certain provisions of this Law that shall apply to the person receiving the exemption.

3. No one shall use the word "bank" or derivatives of the word "bank" in respect of a business, product or service without a banking license issued by Da Afghanistan Bank, unless such usage is established or recognized by law or international agreement, or unless it shall be clear from the context in which the word "bank" is used that it does not concern banking activities. Representative offices shall not use the word "bank" in their name, except in cases where the word "bank" forms an integral part of the name of the bank to which they belong, provided that the word "representative office" is added. Banks whose banking license has been revoked shall carry in their name the words "bank in liquidation."

4. Da Afghanistan Bank shall be empowered to enter the offices and to examine the accounts, books, documents and other records of any person if Da Afghanistan Bank determines that there are reasonable grounds to suspect that such person engages in activities that are incompatible with the preceding provisions of this Article 2; immediately upon the request of Da Afghanistan Bank, law enforcement officials shall, if necessary by use of force, assist Da Afghanistan Bank to gain access to the premises of such person and to examine the accounts, books and other records of such person.

5. If Da Afghanistan Bank determines that a person engages in activities that are incompatible with the preceding provisions of this Article 2, Da Afghanistan Bank shall serve an order upon that person promptly to cease such activities. If Da Afghanistan Bank

determines that, within one calendar week from the date of service of its order, the activities have not ceased, Da Afghanistan Bank shall apply to the Financial Services Tribunal and the 
Tribunal may upon such application decide that the assets, books and records of that person be seized and secured by Da Afghanistan Bank. Within one calendar week following the date of its decision, the Tribunal shall commence hearings concerning the matter in which shall participate Da Afghanistan Bank, the person addressed by the order of Da Afghanistan Bank, and such other interested parties as the Tribunal may invite. Upon conclusion of the hearings, the Tribunal shall either decide upon the liquidation of the assets of that person in accordance with Article 63 or lift the seizure and decide if and to what extent, Da Afghanistan Bank must pay damages to such person as determined by the Tribunal. In case of a liquidation, the proceeds of liquidation shall be used to pay judicial expenses and other costs of $\mathrm{Da}$ Afghanistan Bank, depositors and other creditors of the person concerned, in that order of preference, while any remaining assets shall be transferred to their owner or be forfeited to the State.

\section{Article 3. Public consultation procedure for banking regulations}

1. If $\mathrm{Da}$ Afghanistan Bank proposes to issue a regulation pursuant to this Law, it shall publish a draft of the proposed text of the regulation in the manner appearing to it to be best calculated to bring the proposed regulation to the attention of the domestic banking industry. The draft shall be accompanied by an explanation of the purpose of the proposed regulation and a notice that comments about the proposed regulation may be made to $\mathrm{Da}$ Afghanistan Bank within a specified time of not less than one month after the date of publication of the draft.

2. In preparing the final text of the regulation, Da Afghanistan Bank shall have regard to any comment made to it in accordance with paragraph 1 . If the regulation is issued, Da Afghanistan Bank shall publish an account in general terms of the comments made to it in accordance with paragraph 1 and its response to them. If the text of the regulation differs from the draft published under paragraph 1 to an extent which, in the opinion of Da Afghanistan Bank, is significant, Da Afghanistan Bank shall also publish a general review of the difference. 3. The provisions of paragraphs 1 and 2 shall not apply to a proposed regulation if Da Afghanistan Bank decides that the delay involved in complying with these provisions would be a serious threat to the interests of the banking system; such decision shall be explained in the preamble to the regulation.

Article 4. Treatment of foreign interest in domestic banking activities 1. Non-resident banks and non-resident bank holding companies may be permitted by Da Afghanistan Bank to have qualifying holdings in banks licensed by Da Afghanistan Bank, and to maintain domestic subsidiaries under banking licenses and domestic branch offices and domestic representative offices under permits issued by Da Afghanistan Bank, unless Da Afghanistan Bank determines that such holdings or the activities of such subsidiaries or offices would be contrary to the orderly development and proper functioning of the national banking system of Afghanistan.

2. In regulating and supervising domestic subsidiaries of non-resident banks and bank holding companies, domestic branch and representative offices of non-resident banks, and non-resident branch and representative offices of domestic banks, Da Afghanistan Bank shall closely cooperate with the foreign bank regulators concerned, on a basis of reciprocity, ensuring timely exchanges of information adequate to discharge its supervisory responsibilities while preserving the confidential nature of such information. To that end, Da Afghanistan Bank shall enter into cooperative agreements with foreign bank regulators.

\section{Article 5. Immunity from suit}

No person shall be liable in damages for any act or omission in the discharge or purported discharge of his functions under this Law while a member of the Supreme Council of Da Afghanistan Bank, or while a Governor, Deputy Governor, officer, employee or agent of Da Afghanistan Bank, or while a conservator or receiver appointed pursuant to this Law, unless it is shown that the act or omission was in bad faith.

\section{CHAPTER II LICENSES AND PERMITS}




\section{Article 6. Banking licenses and permits}

1. Da Afghanistan Bank has the exclusive right to issue and to revoke banking licenses, and to issue and to revoke permits for banks to operate branch offices and representative offices.

2 Banking licenses and permits issued pursuant to this Law shall be granted for an indefinite period of time and shall not be transferable. They take effect on the date of their issue by Da Afghanistan Bank, unless they specify another effective date.

3. By its decision to grant a banking license or permit, Da Afghanistan Bank may attach conditions or restrictions to the banking license or permit; these may subsequently be modified by Da Afghanistan Bank.

4. Banking licenses may be issued only to companies established and registered pursuant to the law of Afghanistan that have an initial authorized and paid-in capital of not less than 250 million afghanis or such higher amount as shall be specified by regulation of $\mathrm{Da}$ Afghanistan Bank for the purpose.

\section{Article 7. Applications for banking licenses and permits; fees}

1. Banking licenses and permits shall be applied for in writing to Da Afghanistan Bank. Applications shall be in such form and detail, and shall be accompanied by such documents, as shall be prescribed by regulation of Da Afghanistan Bank. 2. Before it approves an application for a banking license or a permit, $\mathrm{Da}$ Afghanistan Bank shall be authorized to carry out financial, criminal, personal and professional background checks of owners of qualifying holdings in the bank and administrators of the bank for which the application is pending. To that end, financial institutions and the national and local tax collection and law enforcement authorities shall provide such information to Da Afghanistan Bank as Da Afghanistan Bank shall request. 3. In order to cover part of its expenses associated with bank licensing and supervision, Da Afghanistan Bank shall charge and collect an application fee on account of each request for a banking license or permit as well as a maintenance fee for each year that a banking license or permit is in effect.

4. Applications for a banking license or permit shall be rejected if Da Afghanistan Bank is not satisfied that the conditions specified by or pursuant to this Law for issuing such license or permit are fulfilled. Da Afghanistan Bank shall publish by regulation standards that it will apply in evaluating applications for a banking license or permit.

\section{Article 8. Licensing procedure for companies that are not yet established}

1. For companies that are not yet established, the procedure for a banking license consists of two stages, namely, a first stage beginning with the submission of a preliminary application for a banking license by the founders of the company, and a second stage beginning with the submission of a final application for a banking license by the company after it has been established and registered. The applications shall be accompanied by supporting documents showing that the applicable general conditions specified by Article 12 for issuing the banking license are met in accordance with regulations issued by Da Afghanistan Bank. During the application process, Da Afghanistan Bank may require that additional documentary evidence be submitted in support of the application.

2. When, after having received a preliminary application for a banking license and having met with the applicants and the proposed administrators of the bank, Da Afghanistan Bank determines that the preliminary application and supporting documents are satisfactory, Da Afghanistan Bank shall notify the applicants that their preliminary application is complete. 3. Within three months from the date of the applicant's notification that the preliminary application for a banking license is complete, Da Afghanistan Bank shall approve or reject the application, and shall send the applicants a copy of its decision; except that for preliminary applications submitted by one or more non-resident applicants this period shall be six months. Decisions approving a preliminary application:

1) must prescribe the minimum amount of capital of the bank to be subscribed and paid in before a banking license may be issued; in determining the minimum amount of capital of the bank, Da Afghanistan Bank will take account of, in 
particular, the business plan and banking activities proposed for the bank in the documents supporting the application;

2) must list any conditions or restrictions that would be attached to the banking license when issued; and

3) may impose special conditions to be met by the applicants before a banking

license may be issued, explaining in detail what must be done to meet the special conditions.

Decisions rejecting a preliminary application, specifying conditions or restrictions to be

attached to the banking license, or imposing special conditions on the applicants, must explain

the grounds on which the application was rejected or give the reasons for the conditions or restrictions.

4. If the preliminary application for a banking license is approved, Da Afghanistan

Bank shall open an account on its books in the name of the prospective bank to receive capital subscription payments. Within six months from the date of the decision approving the preliminary application, the company for which the application was made shall be established and registered in the respective registry by Afghanistan as a company, the minimum amount of capital prescribed by Da Afghanistan Bank shall be subscribed and paid in, and a final application for a banking license shall be submitted to Da Afghanistan Bank by the company, failing which the decision approving the preliminary application shall terminate. A final application shall be accompanied by such supporting documents as shall be required by regulation of Da Afghanistan Bank, including:

1) documentary evidence that the company has been established and registered and that any special conditions imposed by Da Afghanistan Bank have been met; and 2) a written representation issued on behalf of the company that there has been no material change in the information accompanying the earlier application or detailing any material change in such information.

5. As soon as Da Afghanistan Bank determines that the final application and supporting documents provided pursuant to paragraph 4 are satisfactory and payments of capital subscriptions have been received in the account of the company with Da Afghanistan Bank in an aggregate amount at least equal to the minimum amount prescribed by $\mathrm{Da}$ Afghanistan Bank, Da Afghanistan Bank shall issue the banking license and send a written notice thereof to the applicants. Da Afghanistan Bank shall specify the conditions concerning the funds held in the account of the company with Da Afghanistan Bank, and provide for their release to the extent applicable.

\section{Article 9. Licensing procedure for existing companies}

1. Companies may apply for a banking license by submitting to Da Afghanistan Bank an application supported by documents showing that the company has been established and properly registered and that the applicable general conditions specified by Article 12 for issuing the banking license are met in accordance with regulations issued by Da Afghanistan Bank. During the application process, Da Afghanistan Bank may require that additional documentary evidence be submitted in support of the application.

2. When, after having received an application for a banking license and having met with the owners and the proposed administrators of the bank, Da Afghanistan Bank determines that the application and supporting documents provided are satisfactory, $\mathrm{Da}$ Afghanistan Bank shall notify the applicant that the application is complete. Thereafter, the procedure specified in paragraphs 3, 4 and 5 of Article 8 shall be followed, except that the capital subscriptions to be paid in shall not exceed the amount required to bring the total paidin capital of the bank to the minimum level of capital required by Da Afghanistan Bank.

\section{Article 10. Procedure to obtain permits for offices}

1. No domestic bank shall maintain a domestic or non-resident branch office or a non-resident representative office, and no non-resident bank shall maintain a domestic branch office or a domestic representative office, without a permit issued by Da Afghanistan Bank. 2. The permit for a branch office or a representative office shall be requested by submitting to Da Afghanistan Bank an application supported by documents showing that the applicable general conditions specified by Article 12 for issuing the permit are met in accordance with regulations issued by Da Afghanistan Bank. During the application process, Da Afghanistan Bank may require that additional documentary evidence be submitted in 
support of the application.

3. When, after having received an application for a permit for a branch office or a representative office and having met with the owners of the bank and the proposed administrators of the office, Da Afghanistan Bank determines that the application and supporting documents provided are satisfactory, Da Afghanistan Bank shall notify the bank that the application is complete.

4. Within three months from the date of its notification that the application for a permit for a branch office or a representative office is complete, Da Afghanistan Bank shall approve or reject the application, and shall send the bank a copy of its decision. When the application is approved Da Afghanistan Bank shall promptly issue the permit. The permit shall describe the nature and scope of the activities that the office may engage in and shall list any conditions or restrictions attached to the permit. Decisions rejecting an application for a permit or attaching conditions or restrictions to the permit, shall explain the grounds on which the application was rejected or give the reasons for the conditions or restrictions.

5. No permit shall be issued by Da Afghanistan Bank for a non-resident branch office or a non-resident representative office of a domestic bank unless Da Afghanistan Bank is satisfied, following consultations with the bank regulator of the country where the office is to be located, that the office will be adequately supervised by that bank regulator in close cooperation with Da Afghanistan Bank.

\section{Article 11. Cooperation with foreign bank regulator}

Banking licenses for domestic subsidiaries of non-resident banks or non-resident bank holding companies and permits for domestic branch offices and domestic representative offices of non-resident banks may be issued only if an agreement or arrangement of cooperation has been concluded between Da Afghanistan Bank and the competent foreign authorities that supervise the banking activities of the non-resident bank or bank holding company concerned, specifying the allocation of responsibilities between Da Afghanistan Bank and the foreign authorities for supervising the proposed subsidiary, branch office or representative office and the rules and procedures governing exchanges of information between Da Afghanistan Bank and the foreign authorities on the administration, operation and financial condition of the nonresident bank or bank holding company and the proposed subsidiary, branch office or representative office.

\section{Article 12. General conditions for issuing a banking license or a permit}

1. Taking into account the need to ensure the sound and prudent management of banks, a banking license may be issued pursuant to this Law only if Da Afghanistan Bank is satisfied:

1) that in its administration and operations the bank will comply with the requirements of the law of Afghanistan;

2) that the initial capital of the bank will be at least equivalent to the minimum specified by regulation of Da Afghanistan Bank and that it will be sufficient to support the banking activities that the bank plans to engage in;

3) that no facts are known that warrant the assumption that the influence that would be exercised on the bank by one or more of its owners with a qualifying holding in the bank would threaten the sound and prudent management of the bank;

4) that the relationship between the bank and a non-resident enterprise with a qualifying holding in the bank will not hinder Da Afghanistan Bank in the discharge of its supervisory responsibilities because that enterprise would not be supervised effectively in the country or countries where it has its head office or a subsidiary or branch office or because the supervisory authorities of one or more of those countries would not cooperate with Da Afghanistan Bank;

5) that the owners having a qualifying holding in the bank, when natural persons, will be fit and proper persons and, when legal persons, have administrators who will be fit and proper persons;

6) that the administrators of the bank will be fit and proper persons;

7) that the internal control and risk management procedures of the bank will be adequate;

8) that the business plan and financial projections for the bank are adequate;

9) that, if the application concerns a subsidiary of a non-resident bank or a bank 
holding company, the bank or bank holding company has a relevant license from the country where its head office is located and is committed to ensure, on terms and conditions satisfactory to Da Afghanistan Bank, the due and punctual payment of the future liabilities of the bank;

10) that, if the application concerns the subsidiary of a non-resident bank or a nonresident bank holding company, the bank regulator of the country where the head office of the non-resident bank or bank holding company is located has authorized the establishment and licensing of the subsidiary and, following consultations between Da Afghanistan Bank and that bank regulator, that the non-resident bank or bank holding company is adequately supervised on a consolidated basis by that regulator;

11) that, if the application concerns the subsidiary of a bank or bank holding company that has one or more non-resident banking subsidiaries, and following consultations between Da Afghanistan Bank and the foreign authorities supervising the activities of the other banking subsidiaries, that the other banking subsidiaries are adequately supervised on a consolidated basis by such foreign authorities; 12) that membership of the proposed bank in a group of companies will not hinder

Da Afghanistan Bank in the discharge of its supervisory responsibilities; and

13) that such other conditions as Da Afghanistan Bank may specify by regulation will be met.

2. Taking into account the need to ensure the sound and prudent management by banks of their branch offices and representative offices, a permit for such office may be issued pursuant to this Law only if Da Afghanistan Bank is satisfied:

1) that in its administration and operations the office will comply with the requirements of the law of Afghanistan;

2) that the administrators of the office will be fit and proper persons;

3 ) that the internal control and risk management procedures of the office will be adequate;

4) that the business plan and financial projections for the office are adequate;

5) that, if the application concerns a domestic branch office of a non-resident bank, the bank is licensed to receive deposits or other repayable funds from the public in the country where its head office is located;

6) that, if the application concerns a domestic branch office or a domestic representative office of a non-resident bank, that bank is committed to ensure, on terms and conditions satisfactory to Da Afghanistan Bank, the due and punctual payment of the future liabilities of the bank on account of the branch office or representative office;

7) that, if the application concerns a domestic branch office or a domestic representative office of a non-resident bank, the bank regulator of the country where the head office of the bank is located has authorized the establishment of the office and will adequately supervise the bank;

8) that, if the application concerns a non-resident branch office or a non-resident representative office of a domestic bank, the bank regulator of the country where the office is to be located will adequately supervise the office in close cooperation with Da Afghanistan Bank; and

9) that such other conditions as Da Afghanistan Bank may specify by regulation will be met.

\section{Article 13. Register of banks}

1 A central register shall be kept by Da Afghanistan Bank for inspection by the public. The register shall record for each licensed bank, for each domestic branch office and for each domestic representative office: the name, address and registration number; the date on which their banking license or permit was issued or revoked by Da Afghanistan Bank; the charter and other statutory documents of the bank concerned; and the addresses of offices abroad, if any; for branch offices and representative offices the name and address of the bank to which they belong; and information concerning the administrators of the bank or the office including the scope of their authority to commit the bank or the office and their specimen signatures. 2. The register shall record the date on which bankruptcy proceedings are opened against such bank or office or on which such bank or office is closed. 
3. Banks shall notify Da Afghanistan Bank in writing within three days of changes

originating with them in the information recorded in the register concerning them or their offices.

\section{Article 14. Revocation of banking license or permit}

1. The banking license of a bank may be revoked only by decision of Da Afghanistan

Bank on one or more of the following grounds:

1) the license has been obtained on the ground of false or fraudulent statements or other irregularities that occurred in connection with the license application;

2) the bank has not made use of the banking license within six months after the date of its effectiveness, or the bank has ceased for more than six months to engage in the business of receiving money deposits or other repayable funds from the public or making credits or investments for its own account;

3) the bank no longer possesses the minimum amount of capital and reserves required by law or by regulation of Da Afghanistan Bank or can no longer be relied upon to fulfill its obligations towards its creditors, and in particular no longer provides security for the assets entrusted to it;

4) the bank conducts its administration or operations in an unsound or imprudent manner or otherwise violates a law, or a regulation or order of Da Afghanistan

Bank, or any condition or restriction attached to a license, permit or authorization issued to the bank by Da Afghanistan Bank;

5) the bank, or bank holding company or bank of which the bank is a subsidiary, or a subsidiary of the bank, has engaged in criminal activities;

6) any of the conditions listed in sub-paragraphs 3, 4, 5, 6 and 7 of paragraph 1 of Article 12 is not being fulfilled;

7) the bank fails to comply with an order given to it by Da Afghanistan Bank or any other requirement imposed on it by law or by regulation of Da Afghanistan Bank; 8) the bank has become a subsidiary of another enterprise without the prior written authorization of $\mathrm{Da}$ Afghanistan Bank or the provisions on qualifying holdings set out in Article 21 have not been observed;

9) the bank or bank holding company of which the bank is a subsidiary has lost its operating license;

10) the owner or owners of the bank have decided to dissolve or to liquidate the bank;

11) a reorganization, amalgamation, merger or division of the bank has occurred without the written authorization of Da Afghanistan Bank, or the bank has otherwise ceased to exist as a legally or operationally independent entity; 12) Da Afghanistan Bank is hindered in supervising the bank because the bank has moved all or part of its administration, operations, books or records outside Afghanistan without the prior written consent of Da Afghanistan Bank; or 13) Da Afghanistan Bank is hindered in supervising the bank because the bank is a member of a group of companies, or because the bank is a subsidiary of a nonresident bank or a non-resident bank holding company that is not adequately supervised; or 14) bankruptcy proceedings have been opened against the bank.

2. The permit for a branch office or representative office may be revoked only by decision of Da Afghanistan Bank on one or more of the following grounds:

1) the permit has been obtained on the ground of false or fraudulent statements or other irregularities that occurred in connection with the permit application;

2) the bank holding the permit has lost its banking license, or bankruptcy

proceedings have been opened against the bank, or its owners have decided to dissolve or to liquidate the bank;

3) the bank holding the permit has not made use of the permit within twelve months after the date of its effectiveness;

4) the bank holding the permit or the office conducts its activities in an unsound or imprudent manner threatening its solvency or its liquidity, or otherwise violates a law, or a regulation or order of Da Afghanistan Bank, or any condition or restriction attached to a permit or authorization issued for the office by Da Afghanistan Bank;

5) the bank holding the permit or the office has engaged in criminal activities;

6 ) any of the conditions listed in sub-paragraphs 2 and 3 of paragraph 2 of Article 12 is not being fulfilled; 
7) the bank holding the permit or the office fails to comply with an order given to it by Da Afghanistan Bank or any other requirement imposed on it by law or by regulation of $\mathrm{Da}$ Afghanistan Bank;

8) the bank holding the permit has decided to close the office;

9) Da Afghanistan Bank is hindered in supervising the office because all or part of the administration, books and records of the office have been moved outside Afghanistan without the prior written consent of Da Afghanistan Bank; or

10) Da Afghanistan Bank is hindered in supervising the office because the bank holding the permit for the office is not supervised as necessary.

3. Decisions to revoke a banking license or permit pursuant to this Article shall be in writing and include the grounds on which they are taken. Each such decision shall be promptly served on the bank concerned and be registered in the central register of banks by Da Afghanistan Bank. The requirement of service of such decision on a non-resident bank may be met by serving the decision on its branch office or representative office addressed by the decision. 4. Decisions to revoke a banking license of a domestic bank or a permit for a branch office of a nonresident bank pursuant to this Article shall include the appointment of a conservator to take control of the assets, books and records of the bank or branch office in accordance with Article 54.

5. Decisions taken pursuant to this Article shall take effect at the time that they are served on the bank concerned in accordance with paragraph 3.

\section{Article 15. Revocation of banking license or permit upon request}

1. A bank may apply to Da Afghanistan Bank in writing to revoke its banking license or its permit for a branch office or a representative office. The application shall be accompanied by a liquidation plan adopted by the bank and by the financial statements of the bank as of a date preceding the application by not more than three months, together with a report of an independent external auditor acceptable to Da Afghanistan Bank. Within ninety days after its receipt of the request, Da Afghanistan Bank shall decide on the request. 2. The request may be approved only if Da Afghanistan Bank approves the liquidation plan, and if Da Afghanistan Bank is satisfied that the bank or office will be liquidated in accordance with the provisions of Article 62 and that the bank is solvent and will have adequate liquid funds to pay its liabilities to depositors and other creditors upon revocation of the banking license or permit.

3. The decision of Da Afghanistan Bank shall be communicated in writing by $\mathrm{Da}$ Afghanistan Bank to the bank as soon as possible, giving, in the event of a denial of the request, the grounds therefor.

4. Decisions to revoke a banking license or permit upon request pursuant to this Article shall be promptly registered in the central register of banks by Da Afghanistan Bank and have immediate effect.

\section{Article 16. Publication of decisions to revoke banking license or permit}

1. Within five days from the date of the decision to revoke a banking license of a bank or a permit for a domestic branch office or representative office, Da Afghanistan Bank shall publish the decision in a newspaper of general circulation and in the Official Gazette.

2. From the time that a banking license or permit is revoked, the bank or office concerned shall carry in its name the words "in liquidation" and shall be prohibited from engaging in any of the activities authorized by the banking license or permit, except as required for winding up such activities. As soon as possible thereafter, the bank or office shall be liquidated under Article 62 or Article 63. During the winding up of its affairs, the bank or office shall otherwise continue to be subject to the provisions of this Law as if it were still operating under its banking license or permit.

\section{CHAPTER III ORGANIZATION, OWNERSHIP AND ADMINISTRATION}

\section{Article 17. Creation of banks}

Banks may be established by one or more legal or natural persons as founders and shareholders. 
Article 18. Legal structure of banks

Banks shall be registered as companies The specific legal type shall be specified by regulation of Da Afghanistan Bank. Banks shall not change their legal structure or organization without the prior written authorization of Da Afghanistan Bank.

\section{Article 19. Charter and by-laws}

1. Each bank shall have a charter that is approved by Da Afghanistan Bank and is deposited and registered with the central register of banks. Each amendment of the charter of a bank shall require the prior written authorization of Da Afghanistan Bank and must be registered with the central register of banks.

2. To be approved by Da Afghanistan Bank, charters of banks must include such provisions as shall be specified by regulation of Da Afghanistan Bank, in addition to those required by company law of Afghanistan.

3. Each bank shall be governed by by-laws, adopted by its general meeting of shareholders, which in compliance with its charter shall establish:

1) the structure of the organization and administration of the bank, including its operational and administrative units, their sub-units and functions, supervisory positions, and reporting relationships;

2) the duties of each departmental director and the units under his direction and supervision;

3 ) the functions of the audit committee and other permanent internal committees; and

4) the limits of the authority of the administrators of the bank to enter into transactions in the name and for the account of the bank.

\section{Article 20. Capital structure of banks}

1. Every bank must at any time be able to show that its assets exceed its liabilities to third parties by an amount at least equal to the minimum amount of its initial paid-in capital prescribed by Da Afghanistan Bank at the time that its banking license is issued or such higher amount as Da Afghanistan Bank shall require by regulation.

2. No bank shall decrease its capital and reserves by repurchasing shares or distributing capital or reserve assets to its owners without the prior written authorization from Da Afghanistan Bank.

\section{Article 21. Restrictions on qualifying holdings in banks}

1. No person may, without the prior written authorization of Da Afghanistan Bank, acquire a participation in a bank that alone or together with his existing participation in the bank constitutes a qualifying holding in that bank.

2. No person who has a qualifying holding in a bank may, without the prior written authorization of Da Afghanistan Bank, acquire a participation in that bank if such participation constitutes an increase of his qualifying holding in that bank causing the proportion of the voting rights or the capital held by him to reach or to exceed 20 percent, 33 percent or 50 percent or causing the bank to become a subsidiary of that person. 3. No person who has a qualifying holding in a bank may acquire a participation in another enterprise that constitutes a qualifying holding in that enterprise or increase such qualifying holding in that enterprise to reach or to exceed 20 percent, 33 percent or 50 percent of the voting rights or the capital held by him, before informing Da Afghanistan Bank thereof in writing. 4. If a person acquires a participation that constitutes a qualifying holding in an enterprise that has a qualifying holding in a bank, or increases such qualifying holding in that enterprise to reach or to exceed 20 percent, 33 percent or 50 percent of the voting rights or the capital held by such person, that enterprise must promptly obtain the approval of $\mathrm{Da}$ Afghanistan Bank thereof in writing.

5. The authorization of $\mathrm{Da}$ Afghanistan Bank required for any person by paragraph 1, paragraph 2 or paragraph 4 may be requested by submitting to Da Afghanistan Bank a written application accompanied by supporting documents showing that the applicable conditions specified by paragraph 6 for granting the authorization are met in accordance with regulations issued by Da Afghanistan Bank. During the authorization process, Da Afghanistan Bank may require that additional documentary evidence be submitted in support of the request. 
6. Da Afghanistan Bank may issue the authorization only to a person applying for the authorization if Da Afghanistan Bank is satisfied that the following conditions are met:

1) that the applicant is a natural person who is a fit and proper person;

2) that the applicant is a legal person whose administrators are fit and proper persons;

3) that the applicant has not engaged in criminal activities;

4) that no facts are known that warrant the assumption that the influence that would be exercised on the bank as a result of the acquisition would threaten the sound and prudent management of the bank;

5) that, as a result of the acquisition, the bank would not become a subsidiary of an enterprise afterwards will neither be a bank nor a bank holding company;

6) that, if as a result of the acquisition the bank would become a subsidiary of a non-resident bank or a non-resident bank holding company, the bank regulator of the country where the head office of the non-resident bank or bank holding company is located has given its authorization to the acquisition; 7) that the acquisition would not hinder Da Afghanistan Bank in the discharge of its supervisory responsibilities because a non-resident enterprise which would be linked to the bank as a result of the acquisition would not be effectively supervised in the country where its head office is located or because the supervisory authorities of that country could not be expected to cooperate with Da Afghanistan Bank; and 8) that such other conditions as Da Afghanistan Bank may specify by regulation would be met. 7. Within three months from the date that the application is submitted to Da Afghanistan Bank, the application shall be approved or rejected, and the applicant shall be sent a copy of the decision by Da Afghanistan Bank; except that for applications submitted by a non-resident applicant this period shall be six months. If Da Afghanistan Bank issues the authorization, it may fix a maximum period for completing the acquisition. Decisions rejecting an application must explain the grounds on which the application is rejected.

8. If any person acquires a participation without the prior written authorization of Da Afghanistan Bank required by paragraph1 of this Article or fails to observe the maximum period allowed by Da Afghanistan Bank for completing the acquisition of such participation, that person may be ordered by Da Afghanistan Bank in writing that, before a date stated in the order, that person must dispose of his holding or such part of his holding in the bank as shall be specified in the order.

9. No person may dispose of a qualifying holding in a bank before informing $\mathrm{Da}$ Afghanistan Bank thereof in writing. No person may reduce his qualifying holding in a bank so that the proportion of the voting rights or of the capital held by him would fall below

20 percent, 33 percent or 50 percent or so that the bank would cease to be his subsidiary, before informing Da Afghanistan Bank in writing of the size of his holding in the bank that he would retain.

10. Banks must without delay inform Da Afghanistan Bank of any acquisition or disposal of holdings in their capital, including stock redemptions by one or more shareholders, that cause such holdings to exceed or fall below one of the thresholds referred to in paragraph 2 or paragraph 9 , as soon as they acquire knowledge thereof and within three business days at the latest. Banks shall also, within thirty days after the close of its financial year, inform Da Afghanistan Bank in writing of the names and addresses of shareholders having qualifying holdings and the sizes of such holdings.

11. If, at any time, Da Afghanistan Bank determines that it is no longer satisfied that one or more of the conditions specified or referred to in paragraph 6 apply with respect to a person having a qualifying holding in a bank, Da Afghanistan Bank may order that person before a date stated in the order to dispose of his holding in the bank or such part of his holding in the bank as shall be specified in the order.

12. From the date of an order given by Da Afghanistan Bank pursuant to paragraph 8 or paragraph 11 until the person named in the order has disposed of his holding in the bank or such part of his holding in the bank as is specified in the order, the exercise of the voting rights attaching to the shares of capital stock of the bank to be disposed of shall be suspended and the membership in the Board of Supervisors of the bank of any member appointed by or on behalf of that person shall be suspended. Voting rights so suspended shall not be taken into account for the purpose of determining the quorum for any session, including 
any plenipotentiary session, of the General Meeting of Shareholders.

13. Upon the request of Da Afghanistan Bank, the Financial Services Tribunal may

appoint a special administrator who shall be authorized to exercise the voting rights and to replace any member of the Board of Supervisors suspended pursuant to paragraph 12 . The special administrator shall be autonomous in the exercise of such voting rights and in carrying out the responsibilities of the member of the Board of Supervisors whom he replaces.

\section{Article 22. Administrative structure of banks}

1. Each bank shall be administered by a General Meeting of Shareholders as the supreme decision making organ of the bank, a Board of Supervisors as the organ responsible for supervision of the administration and operation of the bank, a Management Board as the responsible executive body carrying out day-to-day administration of the bank, and an Audit Committee responsible for accounting procedures and controls as well as for internal audits. Other boards and committees may be established by the bank's By-laws.

2. Before a person is appointed to serve on the Board of Supervisors, on the Management Board or on the Audit Committee of a bank, the bank must obtain the written authorization of Da Afghanistan Bank of the proposed appointment. Together with its request for authorization, the bank shall submit to Da Afghanistan Bank with respect to that person such documents as would have been required concerning that person if the request for authorization of membership of the person had been submitted to DAB in an application for a banking license pursuant to Article 9.

\section{Article 23. General Meeting of Shareholders}

1. The General Meeting of Shareholders of a bank shall have the following duties and powers:

1) to adopt amendments to the Charter of the bank;

2) to adopt the By-Laws of the bank and amendments thereto;

3 ) to determine the general interest rate policies of the bank, the categories of assets that shall be suitable for investment of the liquid resources of the bank, and the other general financial, accounting, administrative and personnel policies of the bank; 4) to determine the organizational structure of the bank;

5) to establish and close subsidiaries, branch offices and representative offices of the bank;

6) to decide on the participation of the bank in the capital stock of other financial institutions;

7) to appoint and to dismiss the members of the Board of Supervisors, the

Management Board and the Audit Committee of the bank and to determine their remuneration; such remuneration may not be tied to the financial condition or to the financial results of the bank;

8) to determine the powers of the administrators of the bank to enter into commitments in the name and for the account of the bank and the extent to which such powers may be delegated, except that the powers of members of the Board of Supervisors shall not be subject to delegation;

9) to adopt guidelines for the disclosure of commercial interests by the administrators of the bank under Article 28, and amendments to such guidelines; 10) to determine the budget of the bank, the terms and conditions of employment of the administrators of the bank, and the general structure of the conditions of employment of bank employees, agents; 11) to adopt increases in the authorized capital of the bank and to determine the terms and conditions on which shares of capital stock of the bank may be issued; 12) to approve the annual reports and financial statements of the bank, but only upon the recommendation of the Audit Committee of the bank; to determine the net income of the bank; and to decide what amount of such net income shall be transferred to any reserve or paid out as dividend to shareholders;

13) to establish special reserves on the books of the bank; and

14) to decide on the sale, merger, amalgamation, closure and liquidation of the bank. 2. Shareholders shall have voting rights corresponding to their holding of shares of capital stock of the bank. Each shareholder may exercise his voting rights at the General Meeting of Shareholders through an agent. 
3. Regular and extraordinary sessions of the General Meeting of Shareholders may be held. Notices of the date, place and time of each session of the General Meeting of Shareholders, together with the agenda for that session, are sent to the shareholders at least thirty days before the meeting date, except that, if in an emergency urgent issues require a decision of the General Meeting of Shareholders, such notice may be given less than thirty days before the meeting date but should be given at least seven days before the meeting date to the extent practicable under the circumstances. No decisions shall be made on issues that are not on the agenda sent together with the notice. At least one regular session shall be held each year two months after completion of the external audit of the balance sheet and financial statements of the bank for the preceding financial year. Extraordinary sessions may be convened at the request of shareholders together holding 20 percent or more of total voting rights, the Board of Supervisors, the Management Board, and the Audit Committee.

\section{Article 24. Board of Supervisors}

1. The Board of Supervisors of a bank shall have the following duties and powers:

1) to supervise the administration and operation of the bank;

2) to advise the Management Board and the General Meeting of Shareholders;

3 ) to convene by notice each session of the General Meeting of Shareholders and to adopt the agenda for each session, except that the agendas for sessions convened at the request of shareholders, the Management Board or the Audit Committee shall be adopted by them;

4) to authorize transactions of the bank requiring a decision of the General Meeting of Shareholders if such authority is urgently needed;

5) to warn the Management Board if it discovers an infraction by the bank of an applicable law or regulation, and to bring the infraction to the attention of $\mathrm{Da}$ Afghanistan Bank and the General Meeting of Shareholders, unless the Board of Supervisors decides that bringing the infraction to the attention of shareholders or Da Afghanistan Bank is unnecessary on the grounds that the infraction was a unique event and has ceased, that its adverse effects have been corrected, and that appropriate measures have been taken to prevent its recurrence, provided that the relevant findings shall be recorded in the minutes;

6) to give instructions to the Management Board but only if and to the extent that these are needed to ensure sound and prudent management of the bank;

7) to suspend members of the Board of Managers and members of the Audit Committee who become disqualified to serve pursuant to a provision of this Law or in circumstances where their continued presence on the Management Board or the Audit Committee would be incompatible with the need to ensure sound and prudent management of the bank, and to replace them temporarily with other persons, until the suspended members have been reinstated or permanently replaced by the General Meeting of Shareholders; and

8) to represent the bank to the exclusion of the Management Board in all cases where the Board of Supervisors determines that there is a conflict of interest between the bank and two or more members of the Management Board.

Decisions taken by the Board of Supervisors pursuant to sub-paragraphs 4 to 8 shall be placed on the agenda of the next following session of the General Meeting of Shareholders. 2. The Board of Supervisors of a bank shall have an uneven number of not less than three and up to nine members. Board members shall be natural persons appointed by the General Meeting of Shareholders of the bank for a period of not more than four years; they may be reappointed for subsequent terms of equal length. The majority of members of the Board of Supervisors shall not be associated with the bank through ownership, management function, or employment, except as related to their function as members of the Board of Supervisors. The General Meeting of Shareholders shall designate a member of the Board of Supervisors to be Chairman of the Board of Supervisors.

3. A person shall not become a member of the Board of Supervisors of a bank, or shall by decision of the General Meeting of Shareholders of the bank be relieved of his membership of the Board of Supervisors, in the event that he is ineligible pursuant to Article 27. 
4. The Board of Supervisors may take valid decisions by a simple majority of the votes of its members participating in the meeting. Members may not abstain from voting.

\section{Article 25. Management Board}

1. The Management Board of a bank shall be responsible for the management and execution of the bank's activities.

2. The Management Board shall have an uneven number of not less than three members. The members of the Management Board shall be appointed by the bank's General Meeting of Shareholders for periods of not more than [four] years; they may be reappointed for subsequent terms of equal length. The General Meeting of Shareholders shall designate a member of the Management Board to be Chairman of the Management Board.

3. A person shall not become a member of the Management Board of a bank, or shall by decision of the General Meeting of Shareholders of the bank be relieved of his membership of the Management Board of the bank, in the event that he is or becomes ineligible pursuant to Article 27.

4. The Management Board may take valid decisions by a simple majority of the votes of its members participating in the meeting. Members may not abstain from voting.

\section{Article 26. Audit Committee}

1. The Audit Committee of a bank shall have the following duties and powers: 1) to establish appropriate accounting procedures, establish effective accounting and risk management controls for the bank, supervise compliance with such procedures and controls, and audit the bank's accounts and records;

2) to monitor compliance with the laws and regulations applicable to the bank and report to the Board of Supervisors thereon;

3) to deliver opinions on any matters submitted to it by the Board of Supervisors; and

4) to review operations and transactions of the bank on the basis of plans adopted by the Audit Committee, at the request of the Board of Supervisors, at the request of shareholders together holding more than 10 percent of total voting rights, or as specified by the charter of the bank.

2. The Audit Committee shall have an uneven number of not less than three members appointed by the General Meeting of Shareholders of the bank for periods of not more than four years; they may be reappointed for subsequent terms of equal length. The General Meeting of Shareholders shall designate a member of the Audit Committee to be Chairman of the Audit Committee.

3. Every person who is dismissed by the General Meeting of Shareholders of the bank or is ineligible pursuant to Article 27 shall not become a member of the Audit Committee. 4. The Audit Committee may take valid decisions by a simple majority of the votes of its members participating in the meeting. Members may not abstain from voting.

\section{Article 27. Ineligibility of administrators}

A person shall not be eligible to serve as a member of the Board of Supervisors, the Management Board or the Audit Committee of a bank if:

1) he is not a fit and proper person;

2) he already serves as member of another Board or Committee of the bank;

3) he has by law been deprived of the right to sit on the Board or Committee of which he is or is to be a member;

4) he is an employee of a state authority or a municipal body other than in a teaching capacity; or

5) he is related to an administrator of the bank by marriage, blood or kinship up to

the second degree, or he is the adopted child or foster child of an administrator of the bank.

\section{Article 28. Disclosure of commercial interests}

1. Each member of the Board of Supervisors, the Management Board and the Audit Committee shall disclose in full to his Board or Committee the significant commercial interests that he or members of his household have, directly or indirectly. Such disclosures 
shall be made upon first becoming a member and annually thereafter, in accordance with guidelines adopted by the General Meeting of Shareholders.

2. Whenever any matter related to such interest comes up for discussion in such Board or Committee, or in any other committee or working group of the bank with decision making authority, the member concerned shall disclose his interest at the beginning of the discussion, shall not participate in the discussion, shall absent himself from the meeting while discussions on the matter are ongoing, shall take no part in the decision on such matter, and his presence shall not be counted for the purpose of constituting a quorum.

\section{Article 29. Secrecy obligations}

Present and past administrators and employees of a bank shall be required to keep secret, not to use for personal gain and not to permit to be examined by others unless required by law, any information that they obtained in the course of their services to the bank, except that such information may be disclosed to the officers, staff and agents of Da Afghanistan Bank, including the inspectors, auditors, conservators and experts appointed by $\mathrm{Da}$ Afghanistan Bank, and to such other persons by order of a court of competent jurisdiction.

\section{Article 30. Reorganization of banks}

The reorganization, amalgamation, merger or division of a bank, including a bank whose banking license has been revoked, shall be permitted only with the prior written authorization of Da Afghanistan Bank. Authorizations shall be granted only if the resulting bank or banks shall have or receive a banking license.

\section{Article 31. Restrictions on holdings of banks}

1. No bank may, without the prior written authorization of Da Afghanistan Bank, acquire a participation in a legal entity that constitutes or increases a qualifying holding of the bank in that legal entity if as a result of that acquisition:

1) the legal entity would become a subsidiary of the bank;

2) the book value of that holding would exceed 10 percent of the unimpaired capital and reserves of the bank; or

3) the aggregate book value of all such holdings of the bank would exceed 40 percent of the unimpaired capital and reserves of the bank.

Da Afghanistan Bank is authorized to increase these percentages by regulation to 15 percent and 60 percent, respectively.

2. Shares held temporarily during a financial reconstruction or rescue operation, or during the normal course of underwriting, or as a result of the realization of security given in the course of its operations, or in a bank's own name on behalf of others in trust shall not be counted as qualifying holdings for the purpose of calculating the limits specified in paragraph 1 . Shares acquired as described in this paragraph shall be disposed of by the bank without undue delay, except for shares held in trust.

3. The authorization of Da Afghanistan Bank required for a bank by paragraph 1, may be requested by submitting to Da Afghanistan Bank a written application accompanied by documents showing:

1) a certified copy of the decision of the bank authorizing the planned acquisition;

2) the sizes of the qualifying holdings of the bank in other enterprises, including the qualifying holding that would result from the planned acquisition;

3 ) the sizes of the qualifying holdings of other enterprises in the bank;

4) the principal business activities of the legal entity in which the bank plans to acquire a participation and of the other enterprises referred to in subparagraphs 2) and 3) and the locations of their head offices;

5 ) if as a result of the planned participation a legal entity would become a subsidiary of the bank, a list of the administrators of the legal entity and, for each of the administrators such documents as would have been required concerning that administrator if the request had been a banking license application pursuant to Article 9; and 6) if the legal entity in which the bank plans to acquire a participation is a nonresident 
bank, a certificate recently issued by the bank regulator of the country where the head office of the non-resident bank is located that the non-resident bank is licensed to engage in the business of receiving deposits and other repayable funds from the public in that country, and that the bank regulator does not object to the planned acquisition.

4. Within three months from the date of an application for authorization of $\mathrm{Da}$ Afghanistan Bank submitted pursuant to paragraph 3, Da Afghanistan Bank shall issue the authorization, unless it determines:

1) that the requirements of paragraph 3 have not been met;

2) that, if as a result of the planned participation a legal entity would become a subsidiary of the bank, one or more administrators of that entity are not fit and proper persons;

3 ) that facts are known that warrant the assumption that the planned acquisition would threaten the sound and prudent management of the bank, or that justify the suspicion that the legal entity in which the bank plans to acquire a participation has engaged in criminal activities; or

4) that the planned acquisition would hinder Da Afghanistan Bank in the discharge of its supervisory responsibilities: A) because a non-resident enterprise which would be linked to the bank as a result of the planned acquisition is not effectively supervised in the country where its head office is located or B) because the supervisory authorities of that country are not expected to cooperate with Da Afghanistan Bank. If Da Afghanistan Bank issues its authorization, it may fix a maximum period for completing the acquisition. Decisions rejecting an application must explain the grounds on which the application is rejected.

5. If a bank acquires a participation without the prior written authorization of Da

Afghanistan Bank required by this Article or fails to observe the maximum period allowed by

Da Afghanistan Bank for completing the acquisition, that bank may be ordered by Da

Afghanistan Bank in writing that, before a date stated in the order, it must dispose of its qualifying holding or such part of its qualifying holding as shall be specified in the order. 6. If, at any time, Da Afghanistan Bank determines that an enterprise in which a bank has a qualifying holding:

1) engages in criminal activities;

2) as a result of its relationship with the bank, threatens the sound and prudent management of the bank;

3 ) is a bank that has lost its banking license; or

4) is a non-resident bank that is not effectively supervised in the country where it

has its head office or whose supervisory authorities do not cooperate with Da Afghanistan Bank;

Da Afghanistan Bank may order the bank before a date stated in the order to dispose of its qualifying holding in the enterprise or such part of its qualifying holding in the enterprise as shall be specified in the order.

\section{CHAPTER IV OPERATIONAL REQUIREMENTS}

\section{Article 32. General banking principles}

1. Banks shall conduct their administration and operations in a sound and prudent manner and in accordance with the requirements of the law, any conditions and restrictions attached to their banking license or permits issued by Da Afghanistan Bank, and the regulations, guidelines and orders issued by Da Afghanistan Bank.

2. Banks shall: maintain adequate capital and liquid resources; make adequate provision for depreciation of assets, for discharge of liabilities, and for losses; maintain adequate accounting and other records of business; observe sufficient and effective risk controls; and ensure that their assets are diversified as to risk of loss.

3. Da Afghanistan Bank shall by regulation prescribe detailed standards of conduct for banks which Da Afghanistan Bank shall use in its prudential supervision. 4. Whenever an administrator of a bank discovers that the capital of the bank is less than the capital required by law or by regulation of Da Afghanistan Bank, the administrator must promptly notify Da Afghanistan Bank thereof.

5. Da Afghanistan Bank shall issue separate regulations to apply the provisions of 
this Chapter or regulations issued by Da Afghanistan Bank pursuant to this Chapter shall apply to domestic branch offices of non-resident banks.

\section{Article 33. Banking activities}

Banks may engage in the following activities subject to the provisions of their banking license:

1) receiving money deposits (in the form of demand deposits, time deposits or other types of deposit) or other repayable funds, bearing interest or not;

2) extending credits (whether secured or not by collateral or liens), including without limitation: consumer and mortgage creditfinancing of commercial transactions, including (purchasing negotiable instruments at discount without recourse); factoring, with or without recourse; and financial leasing services; 3 ) buying and selling for its own account or for account of customers (including underwriting and brokerage services): money market instruments (including checks, bills of exchange, promissory notes and certificates of deposit); foreign currencies, precious metals and precious stones; exchange and interest rate instruments; stocks and other securities; and forward contracts, swap agreements, futures, options, and other derivatives relating to currencies, stocks, bonds, precious metals or interest rates;

4) entering into contingent commitments, including guarantees and letters of credit, for its own account and for the account of customers; 5) providing clearing, settlement and transfer services for money, securities, payment orders and payment instruments (including checks; credit, debit and other payment cards; travelers' checks; and bank drafts, wire transfers, and preauthorized debits and credits);

6) money broking;

7) safekeeping and administration of valuables, including securities;

8) providing services as portfolio manager of securities or as financial adviser or as financial agent; 9) providing financial information and credit reference services, including general economic and market information; and

10) anything that shall be incidental to the foregoing and such other activities, not prohibited by Article 34, as Da Afghanistan Bank may by regulation authorize as banking activities.

\section{Article 34. Prohibited activities}

No bank shall engage in or participate as an agent, partner or co-owner in wholesale or retail trade, manufacturing, transportation, agriculture or fisheries, mining, building, insurance or other business activities except for activities that are authorized by Article 33 .

Notwithstanding the foregoing, and with the prior written authorization of Da Afghanistan Bank, a bank may temporarily carry on or participate in the carrying on of such activities to the extent necessary to obtain satisfaction of claims; Da Afghanistan Bank may require the bank to cease such activities by a date specified in the authorization.

\section{Article 35. Prudential requirements}

1. When prescribed by regulation of Da Afghanistan Bank, each bank shall observe the maximum and minimum ratios, exposures and other prudential requirements to be maintained by it concerning its assets, off-balance sheet items and various categories of capital and reserves. Such regulations shall prescribe the common procedures and methods of calculation to be followed in their application. The regulations shall take effect not earlier than one month after their publication or such longer period of time as shall be necessary to afford the banks a reasonable opportunity to adjust their assets or liabilities to comply with the regulations. No prudential requirement imposed by Da Afghanistan Bank shall have retroactive effect. 2. In particular, banks shall observe the following requirements when prescribed by regulation of $\mathrm{Da}$ Afghanistan Bank:

1) requirements concerning their liquid resources in relation to the value or change in value of their assets (including guarantees and collateral received), or in relation to their liabilities; banks shall be permitted to meet the requirements concerning liquid resources by maintaining with Da Afghanistan Bank money 
deposits of an equivalent value;

2) requirements concerning the maximum aggregate amount of all or certain

categories of their credits and investments;

3 ) requirements, prescribed in response to exceptional circumstances, concerning

the rate of interest, maturity and other conditions applicable to any type or form

of financing extended or received (including deposits) or applicable to contingent liabilities;

4) requirements concerning the classification and evaluation of assets, and

provisions to be made on the basis of such classification and evaluation, and the

time when earnings on non-performing loans may no longer be accounted for as

income except as received in cash; and

5) prohibitions, restrictions or conditions concerning:

a) the types or forms of credits and investments made, and liabilities assumed (contingent or otherwise);

b) matching as to maturity and interest in respect of assets and liabilities (contingent or otherwise); and

c) unhedged positions, exceeding a specified ratio, in foreign currencies,

precious metals or precious stones; exchange and interest rate instruments; stocks and other securities; and

forward contracts, swap agreements, futures, options, and other derivatives relating to currencies, stocks,

bonds, precious metals or interest rates.

3. Each bank shall ensure that at all times the value of its regulatory capital,

including its unimpaired capital and reserves, shall be equivalent to not less than 12 percent of

the total value of its assets determined on a risk-adjusted basis, or such higher percentage as

specified by regulations issued by Da Afghanistan Bank, whereby not less than one-half of

regulatory capital shall consist of core capital. In applying this paragraph, the meaning of the

terms "regulatory capital" and "core capital" shall be defined, and the values of regulatory

capital, core capital and assets shall be determined, in accordance with the provisions of

regulations issued by $\mathrm{Da}$ Afghanistan Bank.

4. No bank shall grant credit to a person if as a result thereof:

1) the aggregate outstanding principal amount of all its credits to that person

would exceed or increase the amount by which such aggregate outstanding

principal exceeds the equivalent of fifteen percent, or such higher percentage as

specified by regulations issued by Da Afghanistan Bank, of the bank's

unimpaired capital and reserves; or

2) the aggregate amount of principal of large loans that have credit risks, as defined in a regulation of Da AfghanistanBank, would exceed or increase the amount by which such aggregate outstanding principal exceeds the equivalent of two hundred percent, or such higher percentage as specified by regulations issued by Da Afghanistan Bank, of the bank's unimpaired capital and reserves.

5. The limitations specified in paragraph 4 shall not apply to any principal amount of credit that is fully secured by readily marketable collateral as defined by regulation of $\mathrm{Da}$ Afghanistan Bank; however, no bank shall grant such secured credit if as a result thereof the aggregate outstanding principal amount of all its secured credits to the person receiving such credit would exceed or increase the amount by which such aggregate outstanding principal exceeds the equivalent of 15 percent of the bank's unimpaired capital and reserves, or such higher percentage as specified by regulations issued by Da Afghanistan Bank.

6. For the purposes of applying this Article or any regulations issued pursuant thereto, a person shall be deemed to include any other person with whom such person is connected directly or indirectly in such a way that the financial soundness of any of them may affect the financial soundness of the other or others or the same factors may affect the financial soundness of some or all of them, or if as a result of the structure of their relationship the other person is in fact ultimately responsible for the credit outstanding.

\section{Article 36. Relations between banks and their customers}

1. The relations between banks and their customers shall be governed by agreements between them whose terms and conditions may not be changed unilaterally by one of the parties, except as provided by the agreements.

2. Each bank shall be free to determine by or pursuant to written agreements with its customers the terms and conditions on which it does business with its customers, including: 
rates of interest, fees and charges payable by the bank on bank account balances, or payable by its customers on credits and other financial services provided by the bank, as well as the repayment terms of credits provided by the bank. Interest and other charges payable on any amount of debt to banks shall be payable only for the days on which such amount has been outstanding. 3. Da Afghanistan Bank may issue regulations requiring banks to provide to their customers adequate information concerning the terms and conditions associated with deposits, savings and bank credit in such form and substance as the regulations shall specify.

4. All disputes between domestic banks and their domestic customers, and all

claims of domestic customers on non-resident banks on account of activities of domestic branch offices of the banks, shall be adjudicated by the courts of Afghanistan, except for matters specifically within the jurisdiction of the Financial Services Tribunal.

5. Amounts on deposit in an account at a bank, including Da Afghanistan Bank, are subject to special rules if the accounts are considered dormant accounts. If an account holder has not evidenced any interest in the amounts on deposit by recorded transaction or written correspondence with the bank for ten years, on the first business day of the following calendar year the bank shall dispatch by registered post a notice to the account holder at his last known address containing particulars of the dormant account and publish in at least one local newspaper and in the Official Gazette the name of the account holder and the particulars of the dormant account. Not less than thirty days after such notice and publication, if the account holder cannot be located, the bank shall make a detailed report to Da Afghanistan Bank and shall turn over the amount on deposit to Da Afghanistan Bank, to be held in a special account at Da Afghanistan Bank. Da Afghanistan Bank may use the funds in such special account for such purposes as it may determine. In this casefor a period of ten years any owner who, to the satisfaction of $\mathrm{Da}$ Afghanistan Bank furnishes proof of ownership, is entitled to the immediate repayment of the amounts by Da Afghanistan Bank. After expiration of such period, any remaining unclaimed amounts shall be transferred to the Ministry of Finance for inclusion in the revenues of the Government of Afghanistan.

\section{Article 37. Payment of debt in advance of maturity}

Each debtor of a bank may pay all or part of his debt to the bank at any time in advance of its agreed maturity date. Such prepayments may be made subject to a contractually agreed prepayment fee related to the amount prepaid. With respect to debt payable in installments, the bank may elect to apply partial prepayments proportionately to all installments or only to the latest installment. Covenants excluding or restricting this statutory right of prepayment shall be null and void. Each agreement by which a bank provides credit shall specify the prepayment fees, if any, that are applicable to prepayment of the principal amount of the credit.

\section{Article 38. Secured debt}

1. Banks shall be free to determine in agreement with their counterparties whether their respective obligations shall be secured by collateral, guarantees or other commitments. No bank shall accept shares in its own capital stock as security for a debt to the bank without the prior written authorization from Da Afghanistan Bank.

2. In the event of a payment default on debt to a bank secured by a pledge of or a lien on movable goods, or by a mortgage on immovable or other registered goods, the goods may be sold by public auction or through a broker on a public exchange in accordance with law. The bank may participate in the bidding for the goods. For the event that the goods cannot readily be sold by public auction or on a public exchange for a price that is at least equal to the amount of the debt together with sales costs, the interested parties may agree by notarized agreement, or failing such agreement the court may decide at the request of any interested party, that the goods shall be sold otherwise or that the bank may purchase the goods for a price determined by or in accordance with the provisions of that agreement or a decision of the court. After deduction of the amount of the outstanding debt and costs, the balance of the purchase price shall be paid promptly to the debtor who owned the goods after having satisfied any other person to whom the goods are proven to be pledged by the debtor. If the sales price of the goods net of costs is insufficient to cover the amount of the outstanding debt, the unpaid amount remains an obligation of the debtor to the bank. 


\section{Article 39. Records of transactions and commitments}

1. Banks shall keep on file for at least ten years the pertinent documents for each one of their transactions, namely:

1) the application and all contract documents pertaining to the transaction (including credit, guarantee and collateral agreements);

2) the financial records of the bank's counter parties (including borrowers and guarantors), and any other documentary evidence on which the bank relied in approving the transaction;

3 ) a signed written record of the decision of the bank approving the transaction;

4) the account agreements with its customers; and

5) such other documents as Da Afghanistan Bank may specify by regulation.

2. Records may be kept in electronic form to the extent that adequate data recovery systems and procedures are in place. Da Afghanistan Bank may issue regulations setting out detailed systems requirements.

\section{Article 40. Bank credit to related persons}

1. No bank may extend credit to a related person:

1) if the credit and its financial terms and conditions have not been approved by its Management Board or its Board of Supervisors; or

2 ) if the credit is granted to an administrator of the bank and the credit would cause the aggregate amount of credit disbursed by the bank to that person and outstanding to exceed the equivalent of 25 percent of the annual remuneration of that person, or if the credit would cause the aggregate amount of credits disbursed to all related persons and outstanding to exceed or increase the amount by which such aggregate exceeds the unimpaired capital and reserves of the bank; except that the foregoing percentage limits shall not apply to any principal amount of credit that is secured in compliance with standards prescribed for that purpose by regulation of Da Afghanistan Bank by a mortgage on property whose appraised value at the time that the credit is granted exceeds the principal amount of the credit by not less than one-third of that principal amount; or 3 ) if the credit is granted on terms and conditions that are less favorable to the bank than the terms and conditions that are offered by the bank to the public in the ordinary course of business when the credit is granted.

2. Every credit provided by a bank to a related person shall be promptly reported to the Audit Committee of the bank. If credit has been provided by a bank to a related person in violation of the provisions of paragraph 1 , such credit must be immediately repaid, and the members of the Management Board and the Supervisory Board shall be personally liable, jointly and severally, for payment of principal of, and interest and other charges on, credit granted in violation of paragraph 1 with their knowledge and without their objection.

3. For the purposes of this Article, a related person means:

1) any administrator of the bank;

2) any person who is related to an administrator of the bank by marriage, blood or kinship up to the second degree, or who is the adopted child or foster child of an administrator of the bank; and

3 ) any person who alone or in concert with one or more others or through one or more others has a qualifying holding in the bank, and any enterprise in which any such person or the bank or any administrator of the bank has alone or in concert with one or more others or through one or more others a qualifying holding, and any administrator of such person or enterprise.

\section{Article 41. Prevention of banking services in support of crime}

1. No bank shall maintain accounts on its books or provide services to or for the benefit of undisclosed persons.

2. Each bank shall register the identity of each one of its clients who maintains an account with the bank or otherwise uses the bank for activities including transfers of funds or securities, securities transactions, or the negotiation of payment instruments, or such other activities as Da Afghanistan Bank shall specify by regulation. Each bank shall require each 
such client to provide adequate information to the bank about the identity of any other person who is a beneficiary of such account or for whose account such activities are conducted and shall register the identity of each such other person. Banks shall maintain proof of the identity of the persons so registered.

3. No bank shall maintain an account on its books or provide services to or for the benefit of a person, and each bank shall report to Da Afghanistan Bank any request or instruction to maintain such account or to provide such services, if there are substantiated reasons to suspect that such person engages in transactions connected with money laundering, terrorism or another criminal activity. Da Afghanistan Bank may by regulation issue rules concerning the form, time and content of such reports.

\section{CHAPTER VI ENFORCEMENT MEASURES}

\section{Article 46. Preventive actions}

1. Whenever Da Afghanistan Bank has reasonable cause to believe that the solvency or the liquidity of a bank is threatened because the bank is about to conduct its administration or operations in an unsound or imprudent manner or otherwise to violate a law, or a regulation or order of $\mathrm{Da}$ Afghanistan Bank, or any condition or restriction attached to a license, permit or authorization issued to the bank by Da Afghanistan Bank, Da Afghanistan Bank must notify the bank in writing of its finding and issue a written warning to the bank. 2. If, at any time thereafter, Da Afghanistan Bank determines that the bank fails to heed the warning, Da Afghanistan Bank must order the bank in writing to present to Da Afghanistan Bank, within two weeks of the date of the order, a plan of action that is adequate to prevent such violation.

3. If the bank fails to present such plan in time or if Da Afghanistan Bank determines that the plan presented by the bank is inadequate or if, subsequently, the bank fails to execute the plan, Da Afghanistan Bank must order the bank promptly to take such preventive action as Da Afghanistan Bank may specify.

\section{Article 47. Plan to take corrective action}

1. Whenever Da Afghanistan Bank finds that the solvency or the liquidity of a bank is threatened because the bank:

1) conducts its administration or operations in an unsound or imprudent manner; or

2 ) is otherwise in violation of a law, or a regulation or order of Da Afghanistan

Bank, or any condition or restriction attached to a license, permit or authorization issued to the bank by Da Afghanistan Bank;

Da Afghanistan Bank must notify the bank in writing of its finding and give the bank an order to submit to Da Afghanistan Bank, within such period of time as the order may specify, a written plan of corrective action that identifies the existing weaknesses in the administration or operations of the bank, determines in detail the corrective measures required to remedy such weaknesses, offers a realistic time table for taking such measures, and estimates the effects of the measures on the administration, operations and financial condition of the bank during the execution of the plan.

2. Upon receipt of the plan, Da Afghanistan Bank shall invite the members of the Management Board and the members of the Board of Supervisors of the bank, and if it concerns a domestic branch office of a non-resident bank, the managers of that branch office, to a hearing where the plan and its execution are discussed; Da Afghanistan Bank may invite some or all owners of the bank to participate in the hearing. The hearing shall be concluded when a plan acceptable to Da Afghanistan Bank is adopted. Thereafter, the bank shall promptly carry out the plan, as modified with the prior written authorization of Da Afghanistan Bank, in close consultation with Da Afghanistan Bank.

Article 48. Orders to take prompt corrective action

1. Whenever Da Afghanistan Bank finds:

1) that a bank fails to carry out a plan of corrective action adopted pursuant to Article 47; or 
2) that the solvency or the liquidity of a bank is threatened because the bank conducts its administration or operations in an unsound or imprudent manner, or is otherwise in violation of a law, or a regulation or order of Da Afghanistan Bank, or any condition or restriction attached to a license, permit or authorization issued to the bank by Da Afghanistan Bank, and that corrective action is urgently required,

Da Afghanistan Bank must notify the bank in writing of its finding and must order the bank to take prompt corrective action specified by the order that is adequate to restore compliance within a reasonable period of time specified in the order.

2. Together with an order issued to a bank pursuant to paragraph 1, Da Afghanistan Bank may:

1) impose on the bank a fine up to the equivalent of one percent of the initial authorized and paid-in capital of the bank;

2) order the bank to conduct an external audit of its affairs, at the expense of the bank, by an auditor acceptable to Da Afghanistan Bank;

3) order the bank to do all or any of the following:

a) remove an administrator, officer or employee of the bank from office;

b) ensure that an administrator, officer or employee of the bank does not take part in the management or conduct of the business of the bank except as permitted by Da Afghanistan Bank;

c) appoint a person or persons acceptable to Da Afghanistan Bank as administrator of the bank for such term as the order specifies;

4) order the bank not to give any financial benefit to any person;

5) order the bank not to accept the deposit of any amount;

6) order the bank not to borrow any amount;

7) order the bank not to accept any payment on account of share capital, except payments for or pursuant to call options that fell due before the order was given;

8 ) order the bank not to repay any amount from shares;

9) order the bank not to pay any dividend on shares;

10) order the bank not to repay any money on deposit or advance;

11) order the bank not to pay or transfer any amount to any person, or order the bank not to create an obligation (contingent or otherwise) to do so;

12) order the bank not to undertake any financial obligation (contingent or otherwise) on behalf of any other person;

13) order the bank to increase the unencumbered equity capital of the bank; or 14) order the bank to make any change in the way in which the affairs of the bank are to be conducted or not to be conducted.

3 . Without limiting the generality of paragraph 2 , an order referred to in a subparagraph of that paragraph may:

1) deal with some or all of the matters referred to in that sub-paragraph;

2) deal with a particular class or particular classes of those matters; and

3) make different provision with respect to different matters or different classes of matters.

4. Da Afghanistan Bank shall issue specific guidelines regarding the use of the extraordinary measures set out in sub-paragraphs 10 and 11 of paragraph 12 .

\section{Article 49. Hearings}

1. When Da Afghanistan Bank decides that an order shall be given to a bank pursuant to Article 46, Article 47 or Article 48, Da Afghanistan Bank shall serve the bank with a notice of charges including a statement of the facts constituting the alleged violation or threat of violation supporting the order, describing the order that Da Afghanistan Bank proposes to issue, and scheduling a hearing that will be held to determine whether or not the proposed order should be given to the bank. The first session of the hearing shall be scheduled for a date not earlier than two weeks or later than four weeks after the date of service of the notice. Subsequent sessions may be scheduled by Da Afghanistan Bank by notice to the bank; the date and place of each session shall be notified to the bank in writing not less than two weeks before that date, unless the bank otherwise agrees. The hearing shall conclude when after a session Da Afghanistan Bank advises the bank that no further sessions are needed. 
2. Unless the bank appears at the hearing by a duly authorized representative, it shall be deemed to have consented to the proposed order, in which case the proposed order may be given and served upon the bank.

3. Within one week after conclusion of the hearing, Da Afghanistan Bank shall decide whether or not an order shall be given and shall notify the bank of its decision in writing. If it is decided that an order shall be given, the order shall be promptly issued and served upon the bank together with the text of the decision.

\section{Article 50. Temporary orders}

1. Whenever Da Afghanistan Bank plans to give an order to a bank on the ground that: 1) the bank suffers from or is imminently threatened by a decrease of its capital to less than 75 percent of the capital required by law or by regulation of Da Afghanistan Bank; or

2) the books or records of the bank are so incomplete or inaccurate that $\mathrm{Da}$

Afghanistan Bank is unable, through the normal supervisory process, to determine the financial condition of the bank or the details of any transaction that may have a material effect on the financial condition of the bank;

the order may be given before or during the hearing required by Article 49 in the form of a temporary order.

2. Each temporary order takes immediate effect when it is served upon the bank and shall be fully complied with during the hearing; a temporary order terminates when it is rescinded by Da Afghanistan Bank by notice to the bank or replaced with an order given pursuant to Article 46, Article 47 or Article 48.

3. Each temporary order shall be served upon the bank together with a notice of charges including a statement of the facts constituting the alleged violation or threat of violation and scheduling a hearing in accordance with Article 49 to determine whether or not the temporary order shall be rescinded or replaced.

Article 51. Issue, effect and termination of orders and temporary orders to bank

1. Each order or temporary order given to a bank pursuant to this Law shall be in writing and shall include a statement describing the actions that the bank is ordered to take. Each such order or temporary order may specify the time by which, or period of time during which, it is to be complied with.

2. Each such order or temporary order given to a bank shall be served upon the head office of the bank; except that orders and temporary orders concerning a domestic branch office or representative office of a non-resident bank may be served upon that office. Each such order or temporary order shall be accompanied by a copy of the text of the decision of $\mathrm{Da}$ Afghanistan Bank to give the order or temporary order, stating the factual grounds for the order or temporary order, one or more reasons why the order or temporary order is given, and the provision of the law authorizing Da Afghanistan Bank to give the order or temporary order. 3. Any order issued to a bank by Da Afghanistan Bank, that is not an order that the bank has consented to, may be submitted to the Financial Services Tribunal for review within thirty days from the date of service of the order upon the bank.

4. Each such order or temporary order enters into force at the time of its service upon the bank, unless it specifies a later date for its effectiveness. The order or temporary order remains in effect and shall be fully complied with until it terminates in accordance with its terms, or it is replaced by another order or temporary order of Da Afghanistan Bank, or it is annulled upon review by a decision of the Financial Services Tribunal, or it is rescinded by Da Afghanistan Bank by notice in writing to the bank. Da Afghanistan Bank shall rescind an order or temporary order whenever it is no longer necessary or appropriate.

5. A bank being given an order or temporary order by Da Afghanistan Bank is hereby granted the power to comply with it. Such order or temporary order overrides any provision of the charter of the bank, any license, permit or authorization issued to the bank by Da Afghanistan Bank, and any contract or arrangement to which the bank is a party, whether taking effect before or after the order or temporary order, if such provision presents an impediment to compliance with the order or temporary order; except that an order not to pay or transfer any amount to any person referred to in paragraph 2 of Article 48 does not apply to the 
payment or transfer of money pursuant to an order of a court or a process of execution.

Article 52. Authority of Da Afghanistan Bank

The authority granted to Da Afghanistan Bank by this Law shall not be affected by any prior order, temporary order or plan of preventive or corrective action, and subsequent orders, temporary orders or plans issued under that authority shall be deemed to override prior ones as required to settle conflicts between them.

\section{CHAPTER X RECEIVERSHIP OF BANKS}

Article 64. General bankruptcy law does not apply to banks

Neither the Law of Bankruptcy, dated 15 Qaus 1321, nor any other law amending or replacing the Law of Bankruptcy in whole or part shall apply to banks.

Article 65. Grounds for opening bankruptcy proceedings

1. Bankruptcy proceedings may be opened against a bank on one or more of the following grounds:

1) the bank is not paying its financial obligations as they fall due;

2) Da Afghanistan Bank determines that the capital of the bank is less than

75 percent of the capital required pursuant to paragraph 3 of Article 35;

3) Da Afghanistan Bank determines that the value of the assets of the bank is less than the value of the liabilities of the bank.

2. For the purposes of this Article:

1) the capital of a bank shall be determined in accordance with standards and procedures prescribed by regulation of Da Afghanistan Bank or otherwise acceptable to Da Afghanistan Bank; and

2) the value of the assets and liabilities of a bank shall be determined in accordance with valuation standards and procedures prescribed by regulation of Da Afghanistan Bank or otherwise acceptable to Da Afghanistan Bank.

\section{Article 66. Petition for opening bankruptcy proceedings}

1. Petitions for opening bankruptcy proceedings against a bank shall be submitted in writing to the Financial Services Tribunal.

2. No petition for opening bankruptcy proceedings against a bank may be granted by the Tribunal unless:

1) the petition is presented by $\mathrm{Da}$ Afghanistan Bank, together with financial statements of the bank certified by Da Afghanistan Bank, showing the basis on which one or more applicable statutory grounds for opening bankruptcy proceedings applies; or 2) the petition has been filed with the Tribunal and served on Da Afghanistan Bank by three or more creditors of the bank together with documentary evidence showing that the bank is not paying its financial obligations as they fall due.

Article 67. Appointment of conservator

As soon as a petition for opening bankruptcy proceedings against a bank has been served on Da Afghanistan Bank by creditors of the bank under Article 66, paragraph 2, a conservator shall be appointed by Da Afghanistan Bank pursuant to Article 53 on the ground that the bank is not paying its financial obligations as they fall due. The conservator shall forthwith take control of the bank in accordance with Article 56. The provisions of Article 57 shall not apply and decisions of Da Afghanistan Bank appointing a conservator pursuant to this Article 67 shall not be subject to review by the Financial Services Tribunal.

\section{Article 68. Tribunal hearing}

1. Upon filing of a petition for opening bankruptcy proceedings against a bank, the Financial Services Tribunal shall summon Da Afghanistan Bank and any other petitioner, the conservator appointed for the bank, and the bank to attend a public hearing to consider the petition. In exceptional situations the Financial Services Tribunal may decide to conduct a nonpublic hearing. The hearing shall begin within two business days from the time of filing of the petition. 2. If the petition is filed by Da Afghanistan Bank, the hearing shall be concluded 
within one week. If the petition is filed by creditors of the bank, the hearing shall be concluded within two weeks. At the conclusion of the hearing, the Tribunal shall either reject the petition or grant the petition.

Article 69. Grounds for rejecting the petition

1. A petition for opening bankruptcy proceedings against a bank must be rejected by the Tribunal if:

1) the petition does not meet the requirements of the law; or

2) Da Afghanistan Bank opposes the petition under paragraph 2.

2. If the petition is made by creditors of the bank, Da Afghanistan Bank may oppose the petition only if:

1) Da Afghanistan Bank has determined that no statutory ground for opening bankruptcy proceedings against the bank applies; the Tribunal may require Da Afghanistan

Bank to produce evidence supporting its determination, including financial statements of the bank certified by Da Afghanistan Bank;

2) Da Afghanistan Bank shows to the Tribunal that, before the application for opening bankruptcy proceedings against the bank was served upon Da Afghanistan Bank, the banking license of the bank had been revoked and a conservator had been appointed to liquidate the bank; or 3) Da Afghanistan Bank submits to the Tribunal a decision of the President of Afghanistan in accordance with Article 61 that the stability of the banking system of Afghanistan requires the rehabilitation of the bank.

At its request, Da Afghanistan Bank shall be granted two weeks in which to submit such evidence or decision, before the Tribunal rules on the petition.

3. Otherwise, the Tribunal may reject a petition for opening bankruptcy proceedings against a bank only if:

1) the petition is not accompanied by the documents required by Article 66, paragraph 2;

2) any document or other evidence submitted to the Tribunal in support of the petition is manifestly false or inaccurate and without such document or other evidence the petition does not meet the requirements of the law; or 3 ) the bank shows to the satisfaction of both the Tribunal and Da Afghanistan Bank that payments of supplemental subscriptions to the capital of the bank have been received by the bank in immediately available funds sufficient to eliminate the grounds for opening bankruptcy proceedings against the bank under Article 65.

\section{Article 70. Rejection of frivolous petitions filed by bank creditors}

1. At any time after the filing of a petition for opening bankruptcy proceedings against a bank by creditors of the bank, the Tribunal may reject the petition in writing, with or without a hearing, on the ground that the petition is frivolous, in which case the Tribunal may order the petitioner to pay costs and damages to the bank and to Da Afghanistan Bank resulting from the filing of the petition.

2. Anyone who is found guilty of filing a frivolous petition for opening bankruptcy proceedings against a bank shall be punished by imprisonment for a period not exceeding 1 yearor by the payment of a fine determined by the Tribunal to be appropriate in the circumstances not exceeding 25,000 afghanis or both.

\section{Article 71. Forced liquidation if bankruptcy petition is rejected}

If a petition presented by Da Afghanistan Bank for opening bankruptcy proceedings against a bank is rejected by the Tribunal on grounds other than those specified in Article 69, Da Afghanistan Bank shall revoke the banking license of the bank and liquidate the bank in accordance with the procedures prescribed by Article 63 .

\section{Article 72. Bankruptcy decision}

By the decision of the Tribunal to grant a petition for opening bankruptcy proceedings against a bank, the bank is declared bankrupt, bankruptcy proceedings are opened against the bank and a receiver is appointed. 


\section{Article 73. Service and publication of bankruptcy decision}

Immediately after the Tribunal has issued a decision opening, or rejecting a petition for opening, bankruptcy proceedings against a bank, the decision shall be served by the Tribunal on Da Afghanistan Bank and on the bank and the Tribunal shall arrange for publication of the decision in the Official Gazette of Afghanistan and in at least one newspaper of general circulation.

\section{Article 74. Receiver}

1. The receiver appointed by a decision of the Tribunal opening bankruptcy proceedings against a bank shall be the person acting as conservator for the bank pursuant to an appointment under Article 54 to the extent practicable, provided that the Tribunal may appoint another person to act as receiver as long as that person has the necessary qualifications as required for a conservator pursuant to paragraph 2 of Article 54. The bankruptcy decision shall specify the remuneration and the other terms and conditions of employment of the receiver. The remuneration and other costs incurred on account of the receiver shall be paid from the assets of the bank for which the receiver is appointed.

2. Da Afghanistan Bank shall indemnify the receiver of a bank for all liabilities and all reasonable costs and expenses incurred by the receiver on account of the receivership to the extent that they exceed the assets of the bank available to meet such liabilities, costs or expenses. 3. Receivers shall carry out their activities under the direction and supervision of the Financial Services Tribunal in close consultation with Da Afghanistan Bank in accordance with Article 95. The Tribunal, on the appointment of the receiver, shall provide the receiver with written directions including a list of activities which the receiver may undertake without the need for involvement of the Tribunal. Although the receiver may at any time apply to the Tribunal for directions, the receiver shall be obligated to apply to the Tribunal for directions only where specifically required to do so by a provision of this Law.

4. A receiver may employ at the expense of the bank for which the receiver has been appointed such independent attorneys, accountants and other specialists, on such terms and conditions, as the Tribunal shall approve.

5. Upon the resignation, death or incapacity to act of the receiver, Da Afghanistan

Bank shall temporarily replace the receiver until a new receiver has been appointed by the Tribunal. 6 . The receiver shall be replaced by the Tribunal if the receiver does not diligently perform the receiver's tasks or when the receiver would no longer be eligible to serve as a conservator pursuant to Article 54, paragraph 2.

7. Persons appointed by the Tribunal to replace a receiver shall be selected from a list of candidates submitted to the Tribunal by Da Afghanistan Bank.

8. Whenever a receiver is replaced, the person replacing the receiver shall succeed to the powers of the receiver, and the books, records and remaining assets of the bank in the custody of the receiver as well as the books and records of the receivership shall be promptly transferred into the custody of that person.

\section{Article 75. Powers of the receiver}

Upon appointment for a bank, the receiver becomes the sole legal representative of the bank, and succeeds to all rights and powers of the shareholders of the bank relating to their shares of capital stock of the bank, the Board of Supervisors of the bank, and the Board of Management of the bank including the power to operate and to liquidate the bank. Claims against the bank are served on the receiver for the bank.

\section{Article 76. Effect of bankruptcy decision}

1. The decision of the Tribunal opening bankruptcy proceedings against a bank shall take effect at the time that the decision is taken.

2. Acts performed by or on behalf of the bank after the bankruptcy decision takes effect are legally void and unenforceable, except for acts performed by or by authority of the receiver for the bank and acts deemed beneficial to the estate of the bank by the receiver and ratified by the receiver. 
3. As a result of the bankruptcy decision, all current court proceedings against the bank are stayed; and no court proceeding against the bank shall commence after the bankruptcy decision takes effect, except with the leave of the Tribunal and subject to such terms as the Tribunal imposes.

4. As a result of the bankruptcy decision, all conservatory attachments and attachments in aid of execution resting on assets of the bank are lifted. Attachments placed and acts of execution performed after the bankruptcy decision takes effect shall be void, except for execution in accordance with the provisions of Article 85 of assets encumbered by a mortgage or lien to the extent of the debt secured by such encumbrance.

5. Neither interest nor any other charge shall accrue on liabilities of a bankrupt bank after the bankruptcy decision takes effect.

6. Transfers of shares of a bankrupt bank made after the bankruptcy decision takes effect, except for transfers made with the prior consent of the Tribunal, shall be void. 7. All legal acts of the bank that are done within ninety days before the time of the decision whereby bankruptcy proceedings are opened against the bank shall upon application of the receiver be declared null and void by the Tribunal if the bank and its counterparty in the act knew or could have known at the time of the act that the act would damage the interests of creditors of the bank. Such knowledge shall be presumed whenever the act consists of:

1) a gift;

2) a payment or transfer to an owner, administrator or member of the staff of the bank, unless such owner, administrator or staff member shows to the satisfaction of the Tribunal that the payment or transfer concerned his employment by the bank or concerned an account maintained with the bank and was not unusual in size, or that he did not know that the payment or transfer would damage interests of creditors of the bank;

3) a payment or transfer before its due date or the transfer of collateral for a debt before the due date of the debt;

4) the conclusion or performance of a contract imposing obligations on the bank that is significantly more onerous than the obligations imposed on the other party or parties to the contract; and

5) an arrangement between the bank and one or more others, other than an eligible financial contract defined in Article 82, permitting an offset between rights and obligations of the bank that without such arrangement would not have been permissible before the time of the bankruptcy decision.

\section{Article 77. Finality in payment and securities settlement systems}

1. Notwithstanding the provisions of Article 55, paragraph 4, Article 63, paragraph 2, sub-paragraph 1, Article 76, paragraph 2 and paragraph 7, sub-paragraphs 2 and 3: 1) irrevocable money and securities transfer orders entered by a bank into a payment or securities settlement system recognized as such by Da Afghanistan Bank shall be legally enforceable and binding on third parties, even in the event of a decision of the Financial Services Tribunal opening bankruptcy

proceedings against the bank, but only if the transfer orders become irrevocable before the bankruptcy decision takes effect; or

2) where a bank enters irrevocable money or securities transfer orders into a payment or securities settlement system after a Tribunal decision opening bankruptcy proceedings against the bank takes effect and the transfer orders are carried out on the day of the Tribunal decision, the transfer orders shall be legally enforceable and binding on third parties, unless the receiver proves that the system operator was aware of the bankruptcy decision before the transfer orders became irrevocable.

2. No law, regulation, rule or practice on the setting aside of contracts and transactions concluded before the Tribunal decision opening bankruptcy proceedings against a bank takes effect shall lead to the unwinding of a netting by a payment or securities settlement system recognized as such by Da Afghanistan Bank because of that decision.

3. For the purpose of this Article: 
1) a transfer order entered into a money or securities settlement system becomes irrevocable at the time defined by the rules of that system; and

2) "netting" means the conversion into one net claim or one net obligation of claims and obligations resulting from transfer orders which a participant or participants in a settlement system either issue to, or receive from, one or more other participants in that system with the result that only a net claim or a net obligation remains.

\section{Article 78. Transfers of bank shares and bank liabilities}

1. At the request of Da Afghanistan Bank, and in the interest of the banking system or to maximize the value of a bank for its creditors, the Tribunal may direct the receiver for the bank on terms and conditions proposed by Da Afghanistan Bank and approved by the Tribunal to do a transaction or a series of transactions providing for:

1) the transfer of all or part of the shares in capital stock of the bank; or

2) the transfer of all or part of the assets of the bank or all or part of the liabilities of the bank, or both.

2. A transaction pursuant to paragraph 1 may be requested and authorized at any time after the filing of a petition for opening bankruptcy proceedings against the bank until the bank has been liquidated.

3. A transaction authorized pursuant to paragraph 1 shall not require the consent of the bank or any of its corporate organs. In reviewing a request to direct the receiver of a bank to transfer part of the obligations of the bank whereby some creditors would be excluded from the transfer, the Tribunal shall take the interests of such creditors into account. A transfer of liabilities shall become effective for all interested parties at the beginning of the day following the day of publication of a notice of the transfer in the Official Gazette of Afghanistan.

\section{Article 79. Property report}

1. Within two weeks from the date of the Tribunal decision opening bankruptcy proceedings against a bank, the receiver shall submit to the Tribunal a property report listing:

1) the assets of the bank, including claims of the bank on account of unpaid subscriptions of capital stock of the bank, loan and guarantee agreements, and agreements of purchase or sale, as well as the book values and estimated liquidation values of the assets; 2) the contracts pursuant to which property of the bank is held by other parties, including rental, lease and collateral agreements;

3 ) the contracts pursuant to which the bank receives services; and

4) the significant transactions entered into by the bank during the period of thirty days immediately preceding the date of the bankruptcy decision.

2. The report shall be updated quarterly and shall be made available for inspection by the creditors of the bank whose claims are included on the list of approved claims prepared pursuant to Article 81 .

\section{Article 80. Registration of claims}

1. Except as provided in Article 81, paragraphs 1 and 2, claims on a bankrupt bank must be registered with the receiver in writing within sixty days from the date that the Tribunal decision opening bankruptcy proceedings against the bank is published in the Official Gazette of Afghanistan; the Tribunal may once extend this term for all creditors by thirty days on grounds of equity. Creditors shall be given a registration receipt upon request.

2. Claims shall be registered together with documentary evidence of the claim and the following information:

1) the name and address of the creditor;

2) the amounts of interest and other charges, penalties and taxes included in the principal amount of the claim; and

3 ) details concerning any mortgage, lien or guarantee securing the claim, including the name and address of any guarantor.

3. The decision of the Tribunal opening bankruptcy proceedings against a bank suspends the prescription of claims on account of deposits recorded in the books or records of the bank. The prescription of all other claims is suspended by their registration. 


\section{Article 81. Admission of claims}

1. Only claims that are registered in accordance with Article 80 may be admitted, except that claims on account of deposits recorded in the books or records of the bank and claims for the bank's employees' unpaid salaries (exclusive of bonuses, amounts due upon severance, or any other payment due the bank's employees in excess of their base salaries) recorded in the books or records of the bank shall be admitted for the amounts so recorded without requiring registration.

2. Registered claims recorded in the books or records of the bank shall be admitted by the receiver as recorded without further proof, except that claims registered for an amount that is less than the amount recorded by the bank shall be admitted only for the lesser amount. 3. Creditors of the bank with claims secured by a mortgage or lien resting on assets of the bank may register their claims for the amount by which the amount of the claim exceeds the expected sales value of the asset in a public auction. Any claim so registered shall not be admitted until the auction has taken place or title to the asset has been otherwise transferred pursuant to Article 85 .

4. Claims whose value is uncertain may be admitted for a value estimated by the receiver. 5. After examining the registered claims, the receiver shall record the claims admitted by him on a list of admitted claims and the claims contested by him on a list of contested claims specifying the reasons for his opposition. Registered claims contested in part shall be recorded on both lists for the admitted part and the contested part respectively. Both lists shall for each claimant specify name and address, the amounts of his claims, and whether the claims are secured by collateral; claims of equal ranking shall be listed together, in the order of their priority of payment.

6. Both lists shall be completed and submitted to the Tribunal for approval within thirty days from the deadline for registration of claims. Thereafter, the receiver shall submit quarterly updated lists to the Tribunal for approval. Before approving the lists, the Tribunal may move claims from one list to the other in consultation with the receiver. The Tribunal may specify the evidence required for the approval of contested claims.

7. The Tribunal shall set dates for hearings where creditors whose claims are contested may submit evidence to prove their claims to the receiver and the Tribunal, provided that such hearings shall be held not later than sixty days after the date on which the list of contested claims is submitted to the Tribunal. Creditors shall be notified of the date of each hearing by mail and by notice placed by the receiver in the Official Gazette of Afghanistan. No creditor need be notified of a hearing by mail more than once for the same claim. Following the hearing, the Tribunal shall decide whether the contested claims shall be approved or rejected. Claims for which the creditor fails to appear at the hearing of which he has been notified by mail shall be regarded as rejected. Creditors whose claims have been rejected shall be notified by the receiver in writing. 8. The approval by the Tribunal of claims shall be final. Claims approved by the Tribunal shall be removed from the list of admitted claims or the list of contested claims and be recorded on a list of approved claims kept by the Tribunal and the receiver. Creditors whose claims have been approved by the Tribunal shall be notified by the receiver in writing.

9. No payment shall be made by the receiver on account of claims that are rejected by the Tribunal. The creditor whose claim has been rejected by the Tribunal may appeal the decision of the Tribunal within [two weeks] after the date of receipt of notice of the decision.

\section{Article 82. Set off and netting}

1. Nothing in this Law and no decision made under this Law shall prevent or prohibit the set off by operation of law of obligations between a bankrupt bank and its counter parties.

2. In determining the rights and obligations between a bankrupt bank and its contractual counter parties, effect shall be given to the termination and set off provisions of eligible financial contracts between them. The net termination value determined in accordance with an eligible financial contract between them shall be a claim of the bank on the counterparty or shall be admitted after its registration as a claim of the counterparty on the bank. In this paragraph 2: 
"net termination value" means the net amount obtained after setting off the mutual obligations between the parties to an eligible financial contract in accordance with its provisions.

"eligible financial contract" means any of the following agreements:

1) a currency or interest rate swap agreement;

2) a basis swap agreement;

3) a spot, future, forward or other foreign exchange agreement;

4) an agreement providing for a cap, collar or floor transaction;

5) a commodity swap agreement;

6) a forward rate agreement;

7) a repurchase or reverse repurchase agreement;

8) a spot, future, forward or other commodity agreement;

9) an agreement to buy, sell, borrow or lend securities, to clear or settle securities transactions or to act as a depository for securities;

10) any derivative, combination or option in respect of, or agreement similar to, an agreement referred to in sub-paragraphs 1 to 9 ;

11) any master agreement in respect to an agreement referred to in sub-paragraphs 1 to 10 ;

12) any master agreement in respect of a master agreement referred to in subparagraph 11 ;

13) a guarantee of the liabilities under an agreement referred to in sub-paragraphs 1 to 12 ; and

14) any agreement of a kind prescribed by regulation of Da Afghanistan Bank; and

3. Except as provided by Article 77, no set off shall be allowed with respect to

claims acquired and debts assumed with respect to a bank after the Tribunal decision opening bankruptcy proceedings against the bank takes effect or with respect to claims acquired and debt assumed in bad faith before that decision takes effect.

Article 83. Termination of current contracts

All current contracts or portions of contracts of a bankrupt bank for the delivery of goods or services, including contracts of sale, rental and lease contracts, hire purchase contracts and employment contracts, may be terminated unilaterally by the receiver within a reasonable time after the petition for opening bankruptcy proceedings has been granted except that the counterparty of the bank may register a claim for compensation for breach of contract.

\section{Article 84. Negotiated settlements}

With the prior approval of the Financial Services Tribunal, the receiver for a bank may enter into and carry out negotiated settlements of claims with any creditor and debtor of the bank. No such settlement shall be subject to opposition or appeal.

\section{Article 85. Secured claims}

1. All assets securing approved claims of creditors against the bank or securing claims of the bank against others shall be sold at public auction by the receiver, except that: 1) securities, foreign currencies and other assets that can be readily sold at market may be sold in the markets where they are traded;

2) securities, foreign currencies and other assets of the bank that secure debts of the bank and that can readily be sold at market may be sold by the creditors holding the assets; and 3 ) if the receiver determines that no reasonable price can be obtained for assets in a public auction, the Tribunal may authorize the receiver to sell the assets privately at a price approved by the Tribunal.

2. The assets of a bankrupt bank other than the assets referred to in paragraph 1 , sub-paragraph 2, must be placed at the disposal of the receiver promptly upon his request.

3 . Any dispute between the receiver and a secured creditor as to the value of an asset securing a claim shall be resolved by the Tribunal unless the asset is sold at market or at public auction, in which event the sales price at market or at public auction shall be conclusive as to the value of the asset.

Article 86. Priority of payments

The assets of a bankrupt bank shall be distributed among its creditors in the following order of priority: 1) the claims on account of deposits that are not in the form of debt securities up to 
a maximum amount of 20,000 afghanis per depositor;

2) all costs and expenses on account of the administration of the bankruptcy;

3) liabilities of the bank on account of conservatorship and rehabilitation;

4) state and local taxes and state social security premiums due over a period of not

more than two years preceding the date of the bankruptcy decision; and

5) claims of unsecured creditors, including claims of employees.

Remaining assets shall be transferred to the owners of the bank pro rata to their respective ownership shares.

\section{Article 87. Liquidation plan}

1. Within ninety days from the date of the decision of the Tribunal opening bankruptcy proceedings against a bank, the receiver shall prepare and submit to the Tribunal for its approval a detailed liquidation plan for the bank. The plan shall include: 1) a current pro forma balance sheet showing the assets and liabilities of the bank valued at their estimated liquidation value and a pro forma balance sheet of the expected assets and liabilities of the bank at a date about three months later; the balance sheets shall show liabilities as admitted claims of creditors as well as approved claims and contested claims of creditors;

2) quarterly statements of past and projected income and expenses of the bank;

3 ) a progress report on the sale and on plans for the sale of major assets or groups of assets of the bank;

4) a report on the judicial or extrajudicial pursuit of claims of the bank, including court action to obtain annulment of fraudulent agreements and the transfers made and rights created by them;

5) a report on illegal activities of administrators of the bank and actions to obtain compensation for the bank;

6) a report on the continuation or termination of ongoing contracts, such as insurance, employment and service contracts of the bank, including a detailed analysis of financial provisions for bank employees;

7) a report on the liabilities of the bank and a schedule of expected payments to

creditors of the bank during the next quarter; and

8) a report on past and future costs and expenses of the receivership.

2. The liquidation plan shall be updated quarterly. After its approval by the

Tribunal, the liquidation plan shall be available for inspection by the creditors of the bank whose claims are included on the list of approved claims prepared pursuant to Article 81 .

Article 88. Rehabilitation of bankrupt banks

No bankrupt bank shall be rehabilitated in whole or in part except as provided by Article 61 .

Article 89. No compromise with creditors

Subject to the provisions of Article 84, there shall be no compromise or other arrangement with groups of creditors concerning a bankrupt bank.

\section{Article 90. General meeting and committee of creditors}

1. There shall be no general meeting of creditors concerning the liquidation of a bankrupt bank unless, at the request of the receiver supported by Da Afghanistan Bank, the Tribunal decides that such meeting is desirable to achieve an efficient liquidation of the bank. 2. There shall be no committee of creditors concerning the liquidation of a bankrupt bank unless, at the request of the receiver supported by Da Afghanistan Bank, the Tribunal decides that such committee is desirable to represent and protect significant interests of one or more classes or groups of creditors.

3. Tribunal decisions authorizing a general meeting of creditors or a committee of creditors shall specify the tasks of the meeting or the committee and the scope of its activities.

Article 91. Immediate advances to depositors

To the extent that the depositors can be identified and contacted, claims on account of demand deposits with a bankrupt bank that are not in the form of debt securities shall as soon as possible be paid in advance of any other distribution up to a maximum amount of 
20,000 afghanis per depositor; such advance payments shall not be affected by rights of the bank to set off.

\section{Article 92. Distribution}

1. Subject to Article 86, approved claims shall be ranked and combined according to their priority of payment and recorded in a distribution schedule. Except for the provisions of Article 91, the amounts to be paid on claims of the same class shall be determined on the basis of the same percentage applied to the amount of available funds.

2. At any time, and consistent with Article 86, the receiver may propose and the

Tribunal may approve a distribution schedule of payments to be made to creditors of the bank with approved claims.

3. Immediately after the approval of a distribution schedule by the Tribunal, the receiver shall make the payments listed in that distribution schedule. Amounts included in a distribution schedule that cannot be paid because the creditors cannot be identified or contacted shall be deposited in an account with Da Afghanistan Bank. The receiver shall publish a notice in the Official Gazette of Afghanistan and one newspaper of general circulation inviting these creditors by name to come forward. The amounts so deposited shall remain available for payment to the creditors or their successors until the statute of limitations for the claims has run out, in which case the unpaid amounts shall be transferred to the state.

\section{Article 93. Bankruptcy proceedings against a domestic branch office or a domestic representative office of a non-resident bank}

1. Bankruptcy proceedings may be opened against a domestic branch office or a domestic representative office of a non-resident bank:

1) if any of the grounds listed in Article 65 applies to such office as if it were a bank; or

2) at the petition of Da Afghanistan Bank, if bankruptcy proceedings have been opened against the non-resident bank in the country where its head office is located or where it principally carries on business.

2. The provisions of this Chapter X shall apply to the domestic branch offices and domestic representative offices of a non-resident bank as if all these offices together form a single domestic bank, and the non-resident bank shall be treated as both the Management Board and the General Meeting of Shareholders of the single domestic bank. All assets, liabilities, acts and omissions of the non-resident bank resulting from or otherwise relating to the business of any such office shall be attributed to that single domestic bank in applying the provisions of this Article 93.

3. At the time that the decision of the Tribunal opening bankruptcy proceedings against a domestic branch office or a domestic representative office of a non-resident bank is served on that office, the non-resident bank shall cease all banking activities in Afghanistan, except for banking activities carried out by or with the prior written authorization of the receiver appointed for that office.

4. In its application in bankruptcy proceedings opened against an office of a nonresident bank, Article 82 only applies to the set off and netting of obligations resulting from or otherwise relating to the business of the non-resident bank in Afghanistan.

5. Bankruptcy proceedings in Afghanistan opened against an office of a nonresident bank shall not limit the rights of creditors of the non-resident bank to pursue foreign assets of that bank in satisfaction of their claims.

\section{Article 94. Banks cross border bankruptcy}

In order to promote equal access of domestic and foreign creditors to a universal pool of assets of a bankrupt bank with cross border activities:

1) if a bankrupt domestic bank has branch offices or representative offices in a foreign country, Da Afghanistan Bank shall cooperate as much as possible with the authorities of that country;

2) if a creditor of a bankrupt domestic bank has received partial payment on his claims in a foreign country, the balance of his claims may be presented for payment together with costs incurred in the Afghan proceeding;

3) the Financial Services Tribunal decides to what extent foreign bankruptcy 
decisions, conservatory measures and bank rehabilitation measures concerning non-resident banks should be recognized with respect to their domestic branch offices and representative offices; and

4) if a non-resident bank is in liquidation in the country where its head office is located or where it principally carries on business, the Tribunal may at the request of Da Afghanistan Bank authorize the transfer to the liquidator in that country of such assets of the non-resident bank as Da Afghanistan Bank shall deem advisable and in the interest of the creditors of that bank.

Article 95. Consultations between the Financial Services Tribunal and Da Afghanistan Bank Before taking any decision affecting a bank declared bankrupt, the Tribunal shall inform Da Afghanistan Bank of its proposed decision and afford Da Afghanistan Bank a reasonable opportunity to give its advice to the Tribunal concerning the proposed decision. In making its decision, the Tribunal shall take account of the advice of Da Afghanistan Bank. In the event that the Tribunal rejects all or part of the advice of Da Afghanistan Bank, the decision shall describe the advice so rejected and give the grounds for the rejection.

\section{Article 96. Termination of bankruptcy proceedings}

1. Upon termination of his tasks, the receiver shall be discharged by decision of the Tribunal, but not before the receiver has prepared and submitted to the Tribunal a report of the receivership. The decision of discharge by the Tribunal shall direct where the books and records of the bank and the receivership shall be deposited.

2. The bankruptcy proceedings against a bank shall be terminated by decision of the Tribunal when all assets of the bank have been liquidated and the proceeds have paid to the creditors of the bank or deposited with Da Afghanistan Bank to remain available for payment to creditors of the bank pursuant to Article 92, paragraph 3.

3. The decision of the Tribunal terminating bankruptcy proceedings against a bank shall be published by the Tribunal in the Official Gazette of Afghanistan.

\section{CHAPTER XI FINAL PROVISIONS}

\section{Article 97. Regulatory autonomy of Da Afghanistan Bank}

In carrying out its tasks, Da Afghanistan Bank shall enjoy autonomous regulatory powers. All regulations, orders and guidelines issued by Da Afghanistan Bank that apply to more than one institution shall be published in the [Official Gazette] and shall take effect on the date of such publication or on such later date as such regulation, order or guideline shall specify. Da Afghanistan Bank shall maintain a public register of such regulations, orders and guidelines.

\section{Article 98. Standards of good administration}

1. Da Afghanistan Bank shall use the powers given it under the law of Afghanistan equitably and uniformly and in accordance with sound administrative practices. It shall refrain from using any such power to serve an objective for which the power was not given or in a manner that is disproportional to what in the circumstances of the case is required to achieve the objective for which the power was given.

2. The decisions of the Central Bank taken pursuant to this Law shall be impartial and shall be motivated only by objective and rational considerations; they shall be executed with fairness and restraint.

3. In carrying out its tasks pursuant to this Law, Da Afghanistan Bank shall be guided by the principle that a burden or restriction which is imposed on a person, or on carrying out an activity or on providing a service, should be proportionate to the benefits, considered in general terms, which are expected to result from the imposition of that burden or restriction.

\section{Article 99. Transitional provisions}

1. Every bank that on the date that this Law enters into effect carries a license issued by Da Afghanistan Bank shall apply to Da Afghanistan Bank for a new license within six months after that date, and that license shall be deemed to terminate on the date that the license is replaced by a new license or the application for a new license is rejected by Da Afghanistan Bank. 
2. Banks whose application for a new license is rejected shall be liquidated in accordance with the procedures prescribed by Article 63 by a conservator appointed by $\mathrm{Da}$ Afghanistan Bank, unless Da Afghanistan Bank in consultation with the Minister of Finance decides that the bank shall continue to exist as a financial institution that does not engage in the business of receiving money deposits or other repayable funds from the public for the purpose of making credits or investments for its own account, provided that any reference to the word "bank" in its name is removed.

\section{Article 100. Repeal of existing laws and regulations}

1. The following laws, and all regulations issued pursuant to such laws, are hereby repealed:

a. The Presidential Edict No.99 dated 1373/5/17 establishing the Law on Money and Banking;

b) The Law on Money and Banking, dated 30 Saraton 1354;

2. In case of inconsistency with a provision of any other law of Afghanistan, this Law shall prevail.

Article 101. Entry into force

This Law shall enter into force when signed. 